
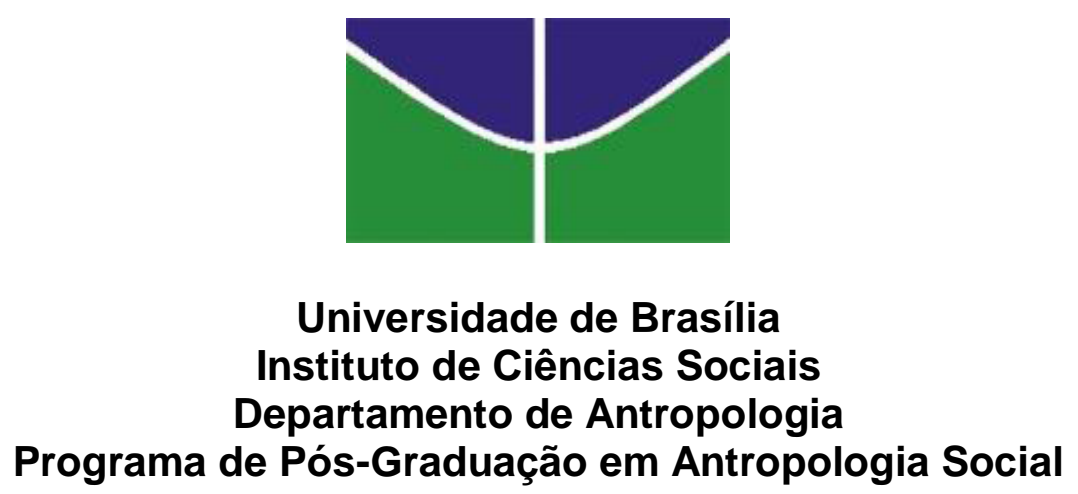

ANDRÉA STEFANI PEIXOTO DA SILVA

\title{
As mulheres de fato e a obrigatoriedade da submissão ao que se nomeia de transexualidade: dilemas da identidade
}


ANDRÉA STEFANI PEIXOTO DA SILVA

\section{As mulheres de fato e a obrigatoriedade da submissão ao que se nomeia de transexualidade: dilemas da identidade}

Dissertação de mestrado apresentada ao Programa de Pós-Graduação em Antropologia Social do Departamento de Antropologia da Universidade de Brasília.

Orientação: Prof. Dr. Luís Roberto Cardoso de Oliveira. 
ANDRÉA STEFANI PEIXOTO DA SILVA

\title{
As mulheres de fato e a obrigatoriedade da submissão ao que se nomeia de transexualidade: dilemas da identidade
}

\begin{abstract}
Dissertação de mestrado apresentada ao Programa de Pós-Graduação em Antropologia Social da Universidade de Brasília como parte dos requisitos necessários à obtenção do título de Mestra em Antropologia Social.
\end{abstract}

Banca examinadora:

Prof. Dr. Luís Roberto Cardoso de Oliveira (UnB/DAN) - Orientador

Prof. ${ }^{a}$ Dra. Antonádia Monteiro Borges (UnB/DAN) - Examinadora Interna

Prof. a Dra. Debora Diniz Rodrigues (UnB/FD)- Examinadora Externa

Prof. ㅁ Dra. Soraya Resende Fleischer (UnB/DAN) - Suplente

Brasília/DF, 15 de julho de 2015. 


\begin{abstract}
"A Verdade!"
E diante disso Orlando despertou.
\end{abstract}

Espreguiçou-se. Levantou-se. Ficou de pé, completamente nu diante de nós. E enquanto as trombetas estrondeavam "Verdade! Verdade! Verdade!", não nos resta outra escolha senão confessar: era uma mulher ${ }^{1}$.

“Ela! Porque não havia nenhuma dúvida sobre seu sexo. Finalmente visita a casa que perdera, pela primeira vez, em mais de cem anos. Todavia, ela possui certas qualidades naturais. É alta e magra e com um ligeiro aspecto andrógeno que as mulheres da época desejam. Sua educação: viveu por quatrocentos anos. Mas não envelheceu um dia sequer. E como aqui é a Inglaterra todos fingem não perceber.

Mas ela mudou!

Não é mais prisioneira do destino.

E desde que se esqueceu do passado, descobriu que sua vida começa agora".

(Orlando - Sally Poter)

\footnotetext{
${ }^{1}$ Virginia Woolf. Orlando - a Biography.São Paulo: Landmark, 2013. p.67
} 


\section{AGRADECIMENTOS}

Agradeço e dedico essa obra às minhas interlocutoras: Bruxa Malvada do Oeste, Úrsula - A Feiticeira do Mar, Maga Patalógicae Malévola por todos os momentos compartilhados. Pelo tempo e afeto dedicado e pela fé em mim e nesta pesquisa. Suas narrativas de vida são fonte de inspiração, de como mudar os caminhos e superar as dificuldades. Sem elas, não apenas não haveria esse trabalho, mas também ninguém contaria essas histórias corretamente!

Agradeço também às minhas irmãs que sempre estiveram comigo. Não importa em que jornadaeu me lance, se grande ou ínfima:Sabrinna, Lela, Cida e Krysestarão sempre ao meu lado!

Ao meu filho, Alejandro Ivo, a vida que segue como um rio!

À minha mãe Ivana Peixoto, hoje uma Musa, cujo útero, sangue e intelecto gerou suas descendentes com ousadia e garra. Dessa linhagem maternalde mulheres guerreiras muito me orgulho em pertencer!

Ao meu pai Ivo Peixoto, inspiração das coisas sociais e políticas; da vida em coletividade com a busca pela honradez e ética!

À minha Ancestralidade de sangue, de terra e de céus!

À força das amigas e dos amigos, em especial, o carinho do ÁbinerAugusto companheiro de vida e jornada!

Ao querido Professor Luís Roberto Cardoso de Oliveira pela delicada, porém firme regência do trabalho; pela crença num esboço, numa ideia, que se tornou obra acabada!

Às Professoras e aos professores do DAN/UnB, em especial as Professoras: Antonádia Borges e Soraya Fleischer, cada uma à sua maneira, cujas provocações foram decisivas para o enfoque e o resultado final dessa dissertação!

Aos funcionários do DAN, em especial ao amigo Jorge Máximo e à Cris que tantas dúvidas e socorros me acudiram!

Às Deusas e aos Deuses da Guerra, do Amor, da Vida e da Morte! 


\section{RESUMO}

Com o estudo etnográfico através danarrativa de cenas de vida de quatro mulheres,objetiva problematizar a submissão ou a obrigatoriedade ao que se nomeia portransexualidadenaprocuraou na realização das cirurgias de adequação genital e nos processos judiciais de alteração de prenome civil e/ou gênero. Para tanto, explorou-se as concepções vigentes sobre a categoria transexual na visão médicopsicológica e nos campos do direito em contraposição à percepção das sujeitas:as mulheres de fato- nascidas com um pênis entre as pernas, embora se afirmem mulheres -na compreensão da identidade real. Neste empreendimento privilegiaramseas demandas de alteração de prenome e/ou mudança de gênero nos documentos civis, assim como a experiência (ou a expectativa)em relação aos procedimentos médico-psicológicos para as referidas cirurgias. Concluiu-se que, em se tratando das interlocutoras do trabalho, aquilo que chamam detransexualidadeconfigura-se como meros processos clínico-jurídicos, uma condição ou situação temporária ou liminar, para a superação de um problema físico e não uma identidadevivida por aquelas sujeitas.

Palavras-chave:Mulheres de fato - Vivência do que se nomeia portransexualidade - Submissão ou obrigatoriedade aosaber médico-jurídico -Processo clínico-jurídico - Condiçãoliminar. 


\begin{abstract}
With the ethnographic study of life narrative scenes of four women, this thesis aims at discussing the subjection of these women to the imposing classification of what is named by transsexuality as a condition to become eligible to surgical intervention of genital adequacy and to file civil lawsuits allowing them to change their gender and their given name. In this connection, the work examines current conceptions of transsexuality in medical-psychological and legal discourses, as opposed to the perception of the subjects themselves: that is, the views of the actual women who are born with a penis between their legs. They look at themselves as plain women and conceive transsexuality as a liminal condition,mere clinical-legal processes, to overcome a physical or a juridical problem but not an identity. Focusing on demands to change their given names and gender on civil documents, as well as on their experiences or expectations about the genital adequacy surgery, the work discusses the struggle for recognition of these women.
\end{abstract}

Keyswords:Real women - Experience of what is named by transsexualitySubjection or obligation to the medical-legal knowledge- Clinical and legal process.Liminalcondition. 


\section{SUMÁRIO}

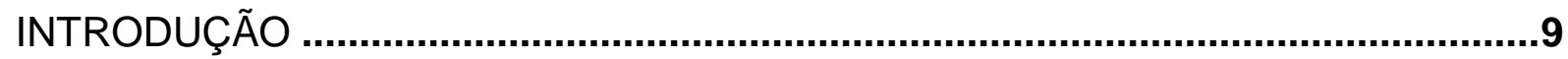

PRÓlogo: (SUgESTÕES PARA MELHOR APROVEITAR A LEITURA).................................15

CAPÍTULO 1: O FALSO PROBLEMA DA IDENTIDADE TRANSEXUAL ..................22

1.1DA PATOLOGIA À CATEGORIA TRANSEXUAL (O FALSO PROBLEMA TRANSEXUAL) .........22

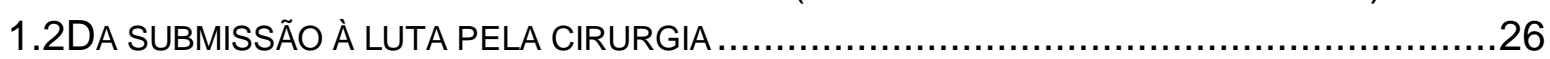

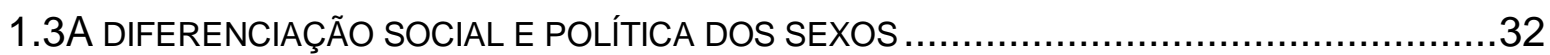

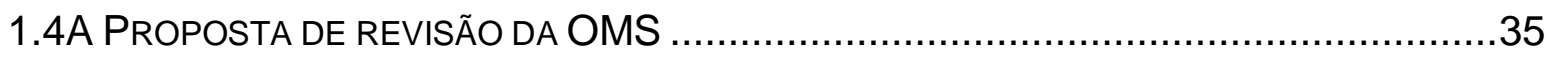

20 PODER JUDICIÁRIO E AS DEMANDAS DE ALTERAÇÃO DE PRENOME E SUBSTITUIÇÃO DE

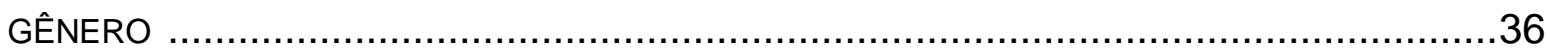

2.1 A atuação moral do Poder Judiciário .....................................................44

2.2 Direito ao esquecimento .........................................................................49

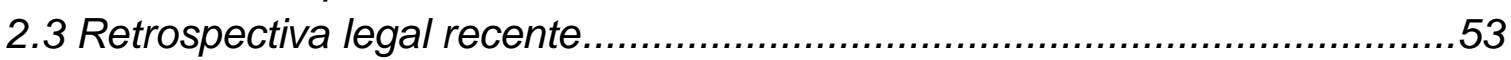

2.4 Fundamentos religiosos no Poder Judiciário ............................................61

3A IDENTIDADE TRANS E O FETICHE ACADÊMICO PELA "TRANSREVOLUCIONÁRIA" ...........65

3. 1 A identidade travesti.................................................................... 72

4 ESTIGMA, AUSÊNCIA DE RECONHECIMENTO E IDENTIDADE: VIOLÊNCIA MORAL ..............74

4.10 estigma........................................................................................ 74

4.20 olhar interno e as questões de identidade.............................................77

4.3Conhecimento e (ausência de) reconhecimento......................................79

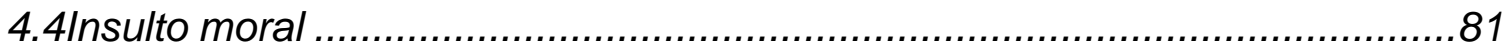

CAPÍTULO 2: BRUXA MALVADA DO OESTE .......................................................86

TEORIA: A SITUAÇÃO LIMINAR E O RITO DE PASSAGEM SECRETO $\ldots \ldots \ldots \ldots \ldots \ldots \ldots \ldots \ldots \ldots . . . \ldots \ldots$

TEORIA: OS RITUAIS PÚBLICOS DE HUMILHAÇÃO ....................................................

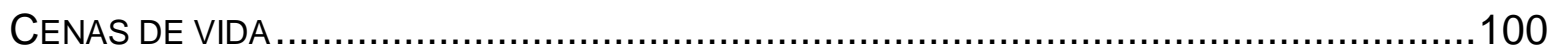

CAPÍTULO 3: ÚRSULA - A FEITICEIRA DO MAR ...............................................122

TEORIA: GÊNERO, SEXO, PRÁTICA SEXUAL E DESEJO NA IDENTIDADE DE BUTLER ..........131

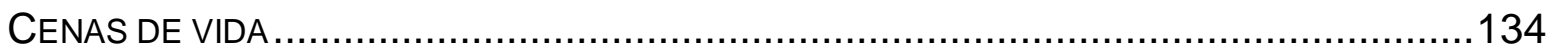

CAPÍTULO 4: MAGA PATALÓGICA ................................................................160

TEORIA: GÊNERO, SEXO, AFETO E SEXUALIDADES NO XANGÔ dO RECIFE .....................166

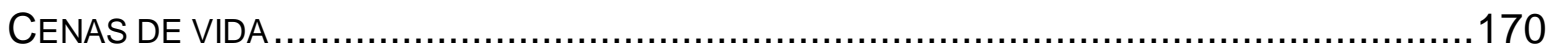

CAPÍTULO 5: MALÉVOLA .............................................................................201

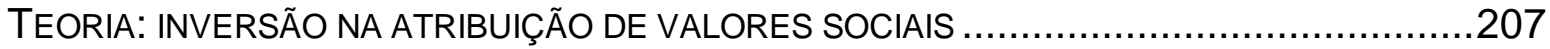

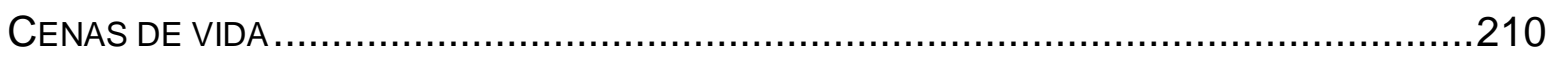

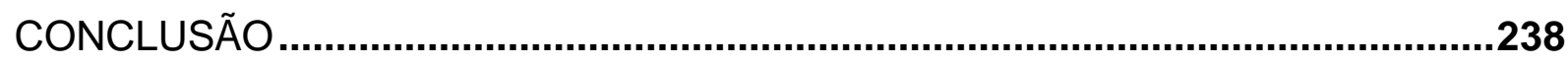

REFERÊNCIAS BIBLIOGRÁFICAS .................................................................243 


\section{INTRODUÇÃO}

Esse trabalho não tem pretensõesem ser a última palavra sobre o tema. Tão pouco explanar de (ou em nome de) uma comunidade de indivíduas que reúna características comuns ou mesmo idênticas, merecendo o uso do termo "grupo social". Igualmente não se presta a substituir discursos legítimos, ousandofalar a partir de um suposto conhecimento especializado - com ares de autoridade - sobre as vidas de outras pessoas. Pretende sim, problematizar o que se nomeia portransexualidade a partir de pequenos trechos ou cenas de vidas de quatro interlocutoras - mulheres de fato - que nasceram com um pênis entre as pernas, embora se afirmem mulheres,cujas experiências procuram trazer na riqueza e complexidade da própria vida:narradas por elas mesmas.

Cinco são as autoras dessas linhas: eu, mestranda em antropologia; Bruxa Malvada do Oeste, estudante de psicologia;Úrsula - a Feiticeira do Mar, costureira e artista;Maga Patalógica, Mãe de Santo eMalévola, maquiladora.

Nesse estudo polifônico, omitiram-se propositalmente diversas informações para evitar a malícia e a curiosidade sobre a vida das interlocutoras. Porém as cenas de vida foram trazidas pelas próprias protagonistas, vasculhando-se memórias, experiências, processos, decisões, fotografias, escritos, receitas. Por não serem biografias (nem se pretender a tanto!), as lembranças partilhadas comigo não se encontram em ordem cronológica ou grau de importância, mas apenas reflexões minimamente direcionadas para ilustrar um tema.

Não estranhe a leitora ou o leitor a aparente bagunça ("messy") dos pronomes pessoais na escrita, entre outras desordens ${ }^{2}$. Nas relações entre pessoas às vezes somos "eu" (para cumprir ritos acadêmicos ou estranhar criticamente uma situação), "nós" (seres humanas capazes de empatia e afeto), "elas" (sujeitas protagonistas das suas histórias), "vocês" ("especialistas da vida alheia" e outras autoafirmadassujeitas "detentoras" de saber-poder). Todo esse Caos pronominal acontece ao mesmo tempo no dia-a-dia.

\footnotetext{
${ }^{2}$ John Law (2004) faz uma interessante análise sobre métodos investigativos não convencionais nas ciências sociais na obra "AfterMethod: mess in social scienceresearch". No livro, argumenta que a melhor maneira de compreender universos sociais num mundo de coisas "complexas, difusas e bagunçadas" é "fazer uma bagunça com isso" (: 2).
} 
Aqui não se aposta emneutralidades há muito esquecidas nas escritas etnográficas. Ao contrário, marca-se uma posição política de relevância ao explicitar asdiferenças entre mulheres e homens nessa nossa sociedade, quando, por exemplo, se desnaturaliza o "sujeito masculino dominante" - ortograficamente universal - na linguagem da norma culta brasileira, substituindo-o pela identidade feminina vivida e comunicada, como a sujeita a concebe e expressa. Nesse sentido é que termos como "ela",a "sujeita", a "indivídua", "pesquisadora", "membra", entre outros, inspirada no estudo etnográficoda professora Antonádia Borges ${ }^{3}$, no "comprometimento afetivo e epistemológico", reforçam meu reconhecimento das identidades das interlocutoras ao mesmo tempo em que instabilizo posições pretensamente neutrasainda fortemente utilizadas na construção do saber científico, através da linguagem.

Algumas dezenas de ensaios, pesquisas e trabalhos acadêmicos abordam o que se poderia chamar de tema central deste trabalho: o que se chama ou se consensuounomear de transexualidade. Mas a maioria, pouco ou nada se propõe a abrir espaço de reflexão para que as sujeitas diretamente interessadas falem de suas experiências, sem interpretações equivocadas a partir do que se acha que elas estejam falando.

Quanto a mim, conquistei e mantenho laços de amizade com cada uma das interlocutoras. Uma delaseu conheço há quase vinte anos. Nem sabemos ao certocomo a amizade se aprofundou, porém repousa hoje sobre bases sólidas de amor, carinho e respeito. Com outra, aprendi o que é uma espera sem fim, na fila angustiante de um hospital público brasileiro. As conversas fluíram primeiramente como desabafos; depois a vontade de falar sobre o quotidiano, não apenas dessas questões, mas de diversas outras, descortinando-se à minha frente uma cantora, uma artista, mestra na arte de viver. Com a terceira, o primeiro contato se deu há alguns anos na militância dos movimentos de mulheres. Nasceu a amizade, depois a admiração e o carinho. A vontade de narrar sua vida com suas palavras surgiu de experiências anteriores em que diversos "especialistas da vida alheia" matraqueavam sem nenhuma atenção ou cuidado com o que ela dizia. Finalmente, a quarta sujeita conheci através de amigos em comum, igualmente na militância.

\footnotetext{
${ }^{3}$ Ver em: "Ser embruxado: notas epistemológicas sobre razão e poder na antropologia" (2012). p. 469-488. Antonádia Borges é Professora-Doutora do PPGAS/ICS/DAN/UnB.
} 
Apresentei a ela minha proposta de trabalho e ela assentiu quando se cercou de cuidados com alguma revelação que não gostaria que ocorresse, também, em virtude de já haver sido mencionada em outros eventos de forma errada.

A escolha por nomeá-las como bruxas de fábulas ou desenhos animados surgiu do compromisso assumido para preservá-las, protege-las dacuriosidade das pessoas. E igualmente para refletir, a partir das visões maniqueístas sobre as antagonistas das narrativas fabulosas, quais paralelos se pode fazer entre reproduzir os estereótipos de personagens desacreditadas, justificando nelas seus finais trágicos; ou se propor a imergir nas dimensões obscuras - mais profundas descobrindo que os príncipes e princesas possuem lados tão perversos quanto a pior das Demônias. Tarefa impensável num conto de fadas.

A bruxaria é um aspecto importante também para compreender os atos de magia dos quais as interlocutoras se utilizam, investindo energias nas transformações íntimas ou sociais que esperam se realizem. E como bem lembrado por Borges ${ }^{4}$, a antropologia tem dificuldades (ou incapacidade) em entender ou lidar com fenômenos sensíveis que escapam à ordem racional ou ultrapassam a fronteira do exótico, na pretensão em "revelar a essência do oculto", empreendimento esse que as próprias sujeitas não conseguiriam perceber por falta de uma "compreensão privilegiada" como aquela apreendida nas ciências sociais. A minha sorte é que também sou Sortílega ${ }^{5}$.

E assim meu Panteão de Bruxas se formou. Cada uma das Feiticeiras trouxe em suas bagagens enormes dificuldades, dores, tristezas, abusos, angústias, tensões. Mas também afetividade, coragem, surpresas, risadas, alegrias e disponibilidade em dividir suas histórias. Com cada uma dessas Sacerdotisas, passei dias e dias não apenas gravando, perguntando, anotando, mas sobretudo vivendo e compartilhando momentos que só nós temos. A evocação desses momentos propiciou que as quatro Deusas pudessem falar de si, sem receios da minha desaprovação ou de alguma expectativa pseudo "revolucionária-

\footnotetext{
${ }^{4}$ Idem, p. 471-473.

5 "Que ou aquela que faz sortilégios, feiticeira" definição em: http://www.infopedia.pt/dicionarios/lingua-portuguesa/sort\%C3\%ADlega Último acesso em: 15/05/15.
} 
subversora"de minha parte, apontamentos essencialistas ou intromissões desnecessárias: a escuta foi tão livre quanto os deliciosos bate-papos.

Minha inquietação com esse tema não data de hoje. Pesquiso situações jurídicas como as das protagonistas dessas narrativas desde 2008 , quando estava ainda no curso de direito. Assim, muito do material bibliográfico aqui apresentado (leis, portarias, resoluções, decisões, jurisprudências, etc) se deve, além dos momentos compartilhados com as interlocutoras, às pesquisas que já havia realizado quando no movimento social de mulheres. Como advogada, trabalhei em diversos processos de alteração de prenome e gênero. Alguns felizmente beneficiaram as sujeitas como as do trabalho. Das minhas experiências profissionais, destaquei alguns casos, cujos dados gerais (sem que houvesse como identificar as partes) foram autorizados.Considero, assim, meus conhecimentos jurídicos do tema bastante sólidos.

Não é tradição das ciências sociais perquirir (no sentido inquisitorial, como fazem, por exemplo, as polícias) as pesquisadas como é habitual na psicologia, na medicina, no direito, entre outros. Mas, ao contrário, reconhecer a autoridade e a legitimidade da trajetóriade cada uma sobre si mesma, seu universo e modo de vida. E também não é minha proposta de trabalho avaliar se as interlocutoras "realmente" vivem o que dizem viver. As palavras delas são mais do que suficientes. O objetivo da antropologia se prestaria a desvendar em que medida e de que maneira os relatos e experiências fazem sentido para elas, e como podem ser mais bemcompreendidos pela disciplina.

Nesse sentido, não se privilegiou os discursos há muito conhecidos e largamente difundidosde médicos, psicólogos, psiquiatras, assistentes sociais, advogados, juízes, promotores de justiça, acadêmicos "especialistas" ou quaisquer outras categorias profissionais, classesou grupos sociais sobre o que se nomeia por transexualidade. Ao contrário, as "verdades" sobre as categorias médico-jurídicas criadas para abarcar um extenso universo de indivíduas de carne e osso são postas na berlinda -em severa postura deavaliação crítica -muito semelhante à forma como aqueles profissionais, representantes ou porta-vozes costumam avaliar as sujeitas para deferir ou negar as demandaspor cirurgias ou alterações de nome e/ou gênero. Para categorizar essas supostas autoridades no tema, tomo emprestado (com 
pequena adaptação) o termo utilizado por uma das interlocutoras, chamando-os de "especialistas da vida alheia", cujo saber-poder serve apenas para contextualizar, partir de um olhar externo,sem jamaiscompreender adequadamente o problema vivido pelas sujeitas.

À questão formulada pela demandante: - "sou uma mulher, embora nascida com um pênis entre as pernas. Desejo a adequação cirúrgica da genitália e a troca do prenome civil e do gênero, para viver plenamente a realidade em que vivo!" A "especialista da vida alheia", de quaisquer das áreas médico-psicológicas, jurídicas ou acadêmicas, responderá com profunda certeza: - "Já entendi! Você é uma transexual!".E quantas vezes a sujeita afirmar-se mulher, tantas outras a "especialista" Ihe atribuirá a suposta identidade "transexual", fazendo-se de surda para as reais necessidades de reconhecimento.

Essa resposta padrão é o que se chama aqui de "categoria ou (suposta) identidade transexual" 6 , via de regra, tomada como precedente absoluto e única via de acesso às cirurgias de adequação da genitália ou alterações civis de prenome e gênero. Para a sujeita significará a submissão àquela categoria se quiser ter êxito nas suas demandas ou alguma inteligibilidade social, na lógica de certificação do Estado.

Assim, para debater sobre o problema da atribuição de identidade esse estudo inicialmente esmiúça a categoria "transexual" e seus afluentes: a visão médico-psicológica, a jurídica, a do movimento LGBTTT e a da academia fetichista representada aqui pela insistência na ótica "queer" sobre as sujeitas. Em seguida, trabalhamos os conceitos de estigma, o reconhecimento da identidade ou sua ausência e a dignidade ofendida. No segundo capítulo, Bruxa Malvada do Oestefala de si com as cenas de vidaconsideradas mais marcantes na sua narrativa. A ênfase está no caráter liminar do que se chama de "transexualidade" na vida da interlocutora, bem como as experiências de humilhação pública.Esse e os demais capítulos etnográficos foram redigidos em duas partes: na primeira, apresenta-se um pouco da trajetória de vida da sujeita, destacando os pontos mais interessantes das cenas que virão a seguir. Ainda nessa parte, há uma pequena discussão teórica

\footnotetext{
6 Para marcar a inadequação dessa categoriaidentitária, utilizamo-la sempre entre aspas
} ("transexual") e/ou antecedida da palavra suposta. 
para destacar algum ponto importante. Na segunda parte, as cenas de vida são explanadas livremente com comentários pontuais. Nessa parte também, os destaques dos trechos das falas das interlocutoras são apresentados no contexto em que foram proferidos. Assim, a leitora ou o leitor saberá de onde retirei os excertos, podendo ter uma visão mais ampla dos argumentos e histórias trazidos pelas entrevistadas. No capítulo três, Úrsula - A Feiticeira do Mar apresenta sua trajetória e cenas de vida. Destacou-se aqui a temática degênero, sexo, identidade e desejo sexual, bem como as diversas situações de violências vividas por ela. Noquarto capítulo, Maga Patalógica nos brinda com suas memórias. A parte teórica levantada diz respeito às manifestações de gênero, sexo, identidade e sexualidade entre os membros da Nação Xangô do Recife/PE similaridades e diferenças na vida da interlocutora. Finalmente, o quinto capítulo contem cenas de vida de Malévolaas quais nos levam a pensar que a genitália não é um problema para a plena realização afetiva e sexual. A questão teórica aqui é deslocar a identidade do exercício satisfatório da sexualidade: o lugar do pênis nas experiências dessa narradora. A dissertação tem como conclusão, ao menos em relação às interlocutoras deste trabalho, que a suposta identidade "transexual" se mostra uma condição temporária, meios (ou obstáculos) clínicos e jurídicosa serem superados para a realização da identidade de mulher.

Por fim, recomenda-se - para uma melhor compreensão sobre as sujeitas aqui apresentadas - efetuar-se uma leitura como nos ensinamentos de Don Juan, seguindo "o caminho com o coração".

\footnotetext{
${ }^{7}$ Don Juan é o Mestre Feiticeiro da etnografia-alegoria de Carlos Castañeda em "A erva do diabo: as experiências indígenas com plantas alucinógenas reveladas por Dom Juan". Seguir o caminho com o coração significa não abdicar das emoções e instintos na busca pelo conhecimento e poder.
} 


\section{PRÓLOGO}

(Sugestões para melhor aproveitar a leitura!).

Para ler essa dissertação, primeiramente, deve-se ter em mente que não se pretendeu biografar as vidas de quatro mulheres, contando os principais eventos, fatos, etapas ou ciclos, com respeito estrito a datas, locais, desdobramentos das escolhas de vida, etc. Pierre Bourdieu (2006) já nos advertia para os equívocos narrativos emse "tratar a vida como uma história, isto é, como o relato coerente de uma sequência de acontecimentos com significado e direção" (: 185).A vida, como se sabe, ultrapassa em muito essas ambições.

Mais interessada eu estava em conhecê-las melhor e me permitir ser conhecida por elas. Após estudar por etnografias muito especiais,diferenciadas e,na

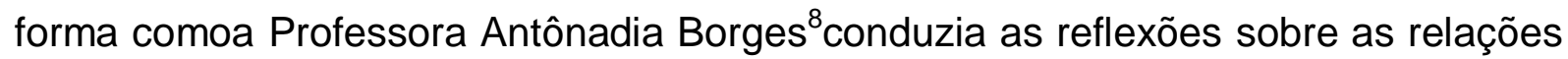
predatórias entre pesquisadoras e pesquisadas na Antropologia, preocupei-me em não cometer os mesmos erros emrealizar uma investigação e uma escrita que fizesse minhas interlocutoras se sentirem objetosem minhas mãos -meras oportunidades para finalizar meus estudos, alcançar reconhecimento e títulos acadêmicos. Definitivamente, não era essa a minha intenção! Todas elas passaram por situações em que se sentiram exploradas por pessoas que igualmente desejavam finalizar estudos, produzir ensaios, obter títulos, sem se importar com elas, em como elas ficariam após o término dos trabalhos. Eu queria algo diferente da apropriação de saberes que atropela as pessoas (a despeito de depender delas para o êxito acadêmico!). Não quis ser uma acadêmica-caçadora que cospe no prato em que come,nem trair a confiança de quemsou muito grata pelos valorosos préstimos de ensinar-me a viver!

Procurei equilibrar um pouco as relações de poder entre a antropóloga e as interlocutoras, assumindo minha ignorância e preconcepções ao afirmar o óbvio: se tem alguém que sabe melhor das vidas das sujeitas são elas mesmas. Tal constatação é fundamental, pois todas elas tiveram as vidas reviradas (algumas devassadas em jornais de grande circulação!), autorizadas, denegadas, periciadas,

\footnotetext{
${ }^{8}$ Disciplina "Epistemologia da Antropologia", oferecida no DAN/UnB pela Professora-Doutora Antonádia Borges no $2^{\circ}$ semestre de 2013. Sobre essas questões guardo vivamente na memória as notas das aulas e desafiadoras impressões ocorridas naquelas sessões.
} 
vasculhadas, testadas, convalidadas, desaprovadas por "especialistas da vida alheia." E naquelas relações elas sequer contavam como sujeitas humanas...

\section{A experiência dos sentimentos e emoções como fonte de conhecimento.}

... Por isso, encarei-as como fez Sandra Harding(1996) em "Ciencia y feminismo" ": revisando criticamente a forma de construção do saber científico nos campos sociais, cujos postulados androcêntricosdevem ser permanentemente problematizados para a consecução de uma "teoria feminista da ciência",encaminhando-nos às práticas científicas mais equânimes.(: 12-13). Devese ter cuidado com as tensões perigosas presentes nos "discursos tradicionais das ciências" com suas "práticas científicas coercitivas",seus "enunciados mistificadores sobre a ciência do ponto de vista histórico" e das suas preleções "regressivas", a partir de uma perspectiva que se pretenda epistemológica e política (:210).

Na obra, Hardinganalisaas críticas feministas no que nomeiade as "cinco origens do androcentrismo na investigação social", que embora não contenham todas as formas de manifestações, nos dão um bom panorama, por exemplo, do problema no olhar funcionalista "de racionalidade weberiana". São elas: 1aㅡ a desconsideração dos sentimentos e das emoções conscientes nas razões ou nas causas das ações sociais e nas crenças das pessoas ao agirem; $2^{a}$ ) as restrições nas análises dos campos de ação social às situações públicas, oficiais, visíveis, espetaculares, ignorando as domésticas,não-oficiais, invisíveis (via de regra, ambientes femininos), reduzindo a compreensão da vida social; $3^{\underline{a}}$ ) a premissa sociológica de uma "sociedade única" em relação a homens e mulheres, sem levar em conta as diferentes perspectivas, posições e interesses, além das interrelações entre as e os agentes que parecem habitar mundos diferentes; $4^{a}$ ) a desvalorização das implicações de sexo como fator relevante de conduta na ação social em diversos campos de estudo. Nos termos da autora: "as interpretações sociais da sexualidade e do gênero são as responsáveis pela designação de funções distintas

\footnotetext{
${ }^{9}$ HARDING, Sandra. Ciencia y feminismo. EdicionesMorata: Madrid, 1996.
} 


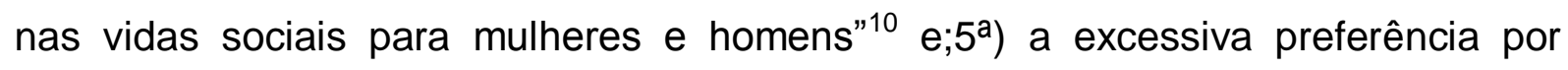
metodologias quantitativaspropiciadorasde manipulação econtrole dosdados. Em outras palavras, a predileção por trabalhar com variáveis ao invés de pessoas(: 76$82)$.

Com o que chama de "projetos de ciência sucessora feminista", a autora finaliza seu estudo, sinalizando possibilidades para uma pesquisa feminista enãoandrocêntrica: a) questionar atitudes autoritárias, ressaltando a experiência pessoal como fonte de conhecimento;b) acreditar, para o incremento político e intelectual, que as hierarquias não são biológicas, mas antes, fruto de criação social passíveis de mudanças; c) analisar as relações sociais entre os gênerosno quotidiano e a função da atividade humana como fonte de conhecimento;d) efetuar uma reforma educativa, privilegiando o saber prático e emocional em detrimento do conhecimento abstrato;dos "esquemas conceituais e pronunciamentos deformados" "dos grandes e renomados" em determinada disciplina: o fundamental deve ser a conscientização; e) manter uma forte orientação humanitária e; f) buscar "a unidade do saber combinando o conhecimento moral e político com o empírico" a unificaro "conhecimento do coração e pelo coração com o que se consegue mediante e sobre o cérebro e a mão."11(: 207-209).

\section{A autoridade plurivocal política e crítica.}

Esse trabalho problematiza também a autoria: o lugar da autoridade numa etnografia contemporânea, como nas críticas de Teresa Pires do Rio Caldeira (1988) em "A presença do autor e a pós-modernidade em antropologia"12. De acordo com Caldeira, no passado a autoridade etnográfica centrava-se no acesso privilegiado que apenas a antropóloga dispunha para "fazer a ponte entre dois mundos

\footnotetext{
${ }^{10}$ Tradução livre do trecho original em espanhol: "Lasinterpretacionessociales de lasexualidad y del género sonlasresponsables de laasignación de funciones distintas enla vida social a mujeresyhombres." (: 79).

11 Tradução livre do seguinte trecho em espanhol: "[...] unificar elconocimientodelcorazón y por elcorazónconel que se consigue mediante y sobre elcerebro y la mano." (: 208).

${ }^{12}$ CALDEIRA, Teresa Pires do Rio. A presença do autor e a pós-modernidade em antropologia. Em Revista Novos Estudos CEBRAP. № 21 julho de 1988.
} 
culturais", numa presença textual ambígua entre "esconder-se" (objetividade científica) e "mostrar-se" (revelar a experiência pessoal). A crítica a esse tipo de fazer antropológico denunciava a presença maciça do autor, apagando todas as outras vozes. Ao não levar em conta sua própria inserção no campo, a antropóloga incorria no que Caldeira chama de "presença insuficientemente crítica", nas relações desiguais e de poder dos enunciados verdadeiros entre a pesquisadora e a nativa. (: 134-135).

A proposta pós-moderna seria então diluir a autoria usando recursos deplurivocalidade, "heteroglossia", na correção dos textos. Desse modo, as antropólogas pós-modernas têm de encontrar formas de representar a diversidade irredutível de experiências. Nas interrelações com as informantes devem-se explicitar os processos de comunicação de sentidos, sabendo que sua voz é apenas mais uma (as vozes são todas equiparadas!) e não a privilegiada, para dispersar autoridade científica (: 141-142). Caldeira destaca uma dimensão pouco explorada: a política e a crítica cultural. Nesse sentido, se questiona se na forma como uma etnografia é escrita, ao se dispersar a autoria, se pode tanto "formular uma crítica cultural, quanto expressar uma posição política" ou seria meramente um efeito gráfico, já que experimentos textuais, em si mesmos, não garantem nada. (: 143). A autora assevera que a diluição da autoria não é o mesmo que desaparecimento do texto, pois se mantém a presença autoral pelas escolhas de citações, reprodução de diálogos, capítulos, apresentação de materiais, entre outros (:148-149). Caldeira afirma que a voz da antropóloga deve ter uma presença crítica, relativa e coexistente com outras, mas que não se anule diante das forças de poder, em termos críticos e políticos (: 151).

\section{A escrita coletiva.}

Além de plurivocal na tentativa de reprodução das cenas de vida, esse trabalho contou com momentos de escrita das próprias interlocutoras. Quase todas as sujeitas tiveram acesso aos textos dos capítulos antes dessa versão. Algumas modificaram trechos ${ }^{13}$, partes inteiras; outras nada mudaram. Em alguns trechos a

\footnotetext{
${ }^{13}$ A exceção de Úrsula - a Feiticeira do Mar que por não possuir e-mail e morar em outra cidade se tornou inviável a troca de textos.
} 
escrita é claramente a quatro mãos. Entretanto, não houve prejuízos ao trabalhoas partes suprimidas ou modificadas, pois em sua grande maioria as interlocutoras desejavam com as alterações explicitar melhor aquilo que nas entrevistas gravadas soava confuso ou embaraçoso (cenas muito íntimas ou descrições de pessoas e fatos, por exemplo) e, sobretudo, desejavam o máximo do anonimato possível sem perder a força narrativa. De todo modo, as modificações não tiveram qualquer impacto nas análises aqui extraídas. Desnecessário, então, reafirmar que o resultado final dessa escrita é da mestranda em antropologia.

O Coletivo Sangtine RichaNagar (2006), em "Playingwithfire: feminist thought and activism through seven lives in India ${ }^{14 "}$ lançam o desafio: "O que escrever? E o que deixar não-escrito?" Segundo as autoras, é preciso manter "verdade e transparência na reflexão coletiva." (: 9). Para se compartilhar momentos há que se ter muito diálogo, trocas, momentos de alegria e dor, apoio e compreensão. Como dito anteriormente, muitas informações aqui foram deixadas sem escrever: o que poderia dar a reconhecer das identidades das sujeitas que devem permanecer anônimas e a pretensão em biografar as histórias. Quanto da vida real, vivida, cabe num ensaio como este? Assim como as Escritoras Sangtin (: xxv), utilizei nas escritas momentos diversos das vidas, como "infância", "adolescência", "relacionamentos afetivos", etc. Em outros trechos, deixei aparecer partes das perguntas para contextualizar melhor o problema ou dilema enfrentado. Entretanto, na tentativa de explorar melhor as emoções, os sentimentos, as percepções íntimas de cada uma delas, depurei o conteúdo, reconhecendo que embora tenha enveredado esforços significativos, ainda assim, uma parcela das cenas virou "salto", espécie de desfecho metanarrativo, semelhantes ao chavão "e viveram felizes para sempre..." Finalmente, assumo que essas extraordinárias jornadas (Yatra) necessitariam de muito mais páginas e enorme investimento de tempo para fazer jus às diversas vidas aqui impressas. Mas acreditamos que fizemos um bom exercício de compartilhar aprendizados.

\footnotetext{
${ }^{14}$ SANGTIN WRITERS.Playing with fire: feminist thought and activism through seven lives in India.Anupamlata... et al: Richa Nagar: Ed. University of Minnesota. Minnesota: 2006.
} 


\section{O caminho com o coração.}

Em "A erva do diabo"15", Carlos Castañeda (2006) relata os caminhos percorridos na compreensão do incompreendido: as múltiplas dimensões e as realidades paralelas; seres humanos e não-humanos interagindo neste mundo; lugares familiares ("spots") - que revigoram a pessoa dona daquele "ponto" e, os não-familiarizados ("inimigos")- que podem até matar caso a indivídua insista em ali permanecer; o uso do conhecimento xamânico e boticário para afastar o mal e trazer o bem; visita de seres de outras dimensões, entre outros tópicos pouco conhecidos.

Naquela obra, o uso das emoções nos permite não abdicar da humanidade por trás da narrativa. Nos ensinamentos de Don Juan, o mestre de Carlos Castañedana assumida "etnografia e alegoria", a chave para se "encontrar o caminho com o coração" é viver de maneira mais eficaz, plena, diferenciando aquilo que realmente é importante de todo o resto. Alguns chamariam de sabedoria, intuição, sensibilidade na busca do seu "spot".

Nas páginas seguintes, procuramos nos sintonizar com as emoções das sujeitas na tentativa de compreensão de situações que alguns diriam "fugir à realidade racional". Ocorre que pode haver outras realidades não cobertas por nossa restrita percepção. A perspectiva analítica buscou entender e problematizar o intangível, sem invalidar as crenças das sujeitas. Como recusar a hospitalidade que alarga nossos horizontes?

De maneiras diferentes, as interlocutoras dessa dissertação se consideram Bruxas, Feiticeiras, Místicas, sensíveis a outras realidades, outras formas de compreender a vida e as experiências da existência humana. Algumas assumem os caminhos solitários da Bruxaria $^{16}$, outras se realizam na religião do Candomblé, suas Deusas, lendas e representações arquetípicas. Uma delas

${ }^{15}$ CASTAÑEDA, Carlos. "A erva do diabo: as experiências indígenas com plantas alucinógenas reveladas por Dom Juan" (The teachingsof Don Juan). Rio de Janeiro: Editora Record, 2006.

${ }^{16}$ Ao contrário das filosofias de caráter essencialmente religiosos, nos caminhos da Bruxaria, também chamada de a "Grande Arte" ou "Arte Antiga" e suas incontáveis variações, a sujeita é em si mesma o centro e a razão do universo. Não é necessário quaisquer religares do "eu" com algum ente ou energia "superior", pois a união total mente-corpo-espírito-emoção acontece na própria sujeita. Nunca houve uma desconexão entre as Bruxas e as Deusas, por isso não é necessário re-ligar contatos. As Bruxas são conhecidas há séculos como praticantesconscientes das artes de "moldar a realidade", modificar as energias para atingir seus objetivos. Sobre bruxas e bruxaria ver em: "Feitiçaria: a tradição renovada", DoreenValiente e Evan John Jones. 
frequenta os cultos Seicho-No-iee nesse momento aprende a importância de (se) perdoar e honrar as Antepassadas. Esses percursos, individuais ou coletivos, levam ao autoconhecimento, como na invocação "O Papel da Deusa", da Bruxa britânica, Doreen Valiente:

"[...] De mim todas as coisas vêm e para mim todas devem retornar. Que a adoração a mim esteja no coração que rejubila, pois saiba, todos os atos de amor e prazer são meus rituais. Que haja beleza e força, poder e compaixão, honra e humildade, júbilo e reverência, dentro de você. E você que busca conhecer-me, saiba que a sua procura e ânsia serão em vão, a menos que você conheça o mistério: pois se aquilo que busca, não se encontrar dentro de você, nunca o achará fora de si. Saiba, pois, eu estou com você desde o início dos tempos, e eu sou aquela que é alcançada ao fim do desejo." ${ }^{17}$

Como nas palavras de Don Juan, chegamos até aqui trilhando o caminho com coração. Pois, acredito que seja a melhor forma de se conhecer alguém e trilhar caminhos ao seu lado.

17 "O Papel da Deusa", invocação de DoreenValientein "Os Encargos da Deusa", "A dança cósmica das feiticeiras". (Starhawk, 1993: 123-124). 
Capítulo 1 - O falso problema da identidade transexual.

I figured out who I was very early on-actually, at the age of 13, with the help of the Internet-so I knew that a transition, becoming a woman, was always something I needed to do. But it wasn't possible at the time, and I put it off, and androgyny became a way of expressing my femininity without having to explain myself to people too much. Especially to my peers [who] couldn't understand things like "trans" and gender identity. And then obviously the modeling thing came up, and I became this androgynous male model, and that was a big part of my growing up and my self-discovery. But I always kept in mind that, ultimately, my biggest dream was to be a girl.

(Andreja Pejic, modelo internacional) ${ }^{18}$

\subsection{Da patologia à categoria transexual. ( 0 falso problema transexual).}

O problema da atribuição de identidade a outrem gera conflitos quando aquela a quem se refere não deseja, não se vê ou se sente da forma que lhe é apontada. O processo de nomeação ocorre de fora para dentro e quase sempre a revelia da sujeita, como uma pecha, um estigma. Nesse sentido, a categorização da indivídua a partir de um olhar externo envolve preconcepções equivocadas, ilusórias ou falsas. O que se pretende por reconhecimento, não passa de uma acomodação dos termos disponíveis de forma a "simplificar" uma suposta compreensão da alteridade a partir dos valores de quem atribui e não de quem vive.

Naquilo que se nomeia por "transexualidade"19 há um fosso, em alguma medida, incomunicável entre o que se demanda e o que se obtém como resposta.

\footnotetext{
${ }^{18}$ O trecho acima é parte da entrevista da modelo internacional Andreja Pejic datada de julho de 2014. Na matéria ela enfatiza o caráter temporal do que se nomeia como "transexualidade", cujo objetivo para ela sempre foi $\mathrm{o}$ de se "tornar uma mulher". Disponível em: http://www.style.com/stylefile/2014/07/andreja-pejic-sexual-reassignment-surgery/ Último acesso em: 27/02/15.
} 
Como se verá, as quatro interlocutoras que disponibilizaram suas histórias neste trabalho, cada uma a sua maneira, negociou os termos ou condições na submissão ao que chamamos de "falso problema transexual" até o desfecho positivo do pleito, seja de uma ação judicial, sejam de procedimentos corporais. Após a solução, voltaram a ser mulheres "sem aspas, sem negrito, sem sublinhado." 20

A "transexualidade"21, forma adjetivada de "transexualismo", cuja "paciente" seria "o transexual", que por sua vez se origina da patologia "transtorno de identidade de gênero", trata-se de uma doença ou, como preferem alguns, uma síndrome ${ }^{22}$, tendo o diagnóstico e o protocolo de atendimento codificados nas atuais versões do CID-10 e no DSM-IV. Em ambos os manuais, resumidamente, as pessoas que manifestarem a queixa ou necessidade da cirurgia de adequação da genitália ${ }^{23}$ deverão se submeter a severos exames psicológicos/psiquiátricos que irão "atestar" ou "declarará" ser a pessoa sofredora dos "sintomas" contidos na categoria "Transexualismo", código "F.64.0", da Classificação Estatística Internacional de Doenças e Problemas Relacionados à Saúde- CID 10, que assim descreve:

F64.0 Transexualismo: Um desejo de viver e ser aceito como um membro do sexo oposto, usualmente acompanhado por uma sensação de desconforto ou impropriedade de seu próprio sexo anatômico, e um desejo de se submeter ao tratamento hormonal e

\footnotetext{
${ }^{19}$ Um dos grupos organizados ("ARACÊ - Mobilização Social em Direitos Humanos, Femininos e Sexualidades") questiona a "transexualidade" como identidade. Para elas, a vivência do processo ou experiência que se convencionou chamar de "transexualidade" é uma condição meramente física e perfeitamente adequável com uso de tecnologia cirúrgica e mudança dos documentos civis. É nesse sentido que utilizamos os termos médico e psicológicos entre aspas, problematizando não apenas a descrição patológica, mas também a suposta identidade "trans" ou "transexual", como única possibilidade e escolha de vida.

${ }^{20}$ Trecho do relato de Bruxa Malvada do Oeste.

${ }^{21}$ Termo resignificado pelo movimento LGBTTT com o objetivo de "desestigmatizar" a patologia.

${ }^{22}$ De acordo com o dicionário Aurélio, em sua versão online, "síndrome" é o "conjunto de sintomas que caracterizam uma doença". Ver em: http://www.dicionariodoaurelio.com/Sindrome

último acesso em: 27/02/15.

${ }^{23}$ Entenda-se por "adequação" o ato de conformar a genitália de nascença àquela do gênero/identidade vivida; "readequar", como alteração radical, no sentido de inovar atribuindo genitais estranhos à vontade da sujeita, o que seria inadequado. A medicina nomeia frequentemente de "redesignação sexual/genital" ou "transgenitalização". O senso comum costuma referir-se a "mudança" ou "troca de sexo". As sujeitas mencionam apenas como "a cirurgia" ou "adequação cirúrgica", por isso optamos por esses termos.
} 
cirurgia para tornar seu corpo tão congruente quanto possível com o sexo preferido (OMS, 1993). (Grifos nossos).

No DSM-IV, Manual Diagnóstico e Estatístico de Transtornos Mentais ${ }^{24}$, o termo "transexualimo" é substituído por "Transtorno de Identidade de Gênero" (em inglês: Gender Identity Desorder) tendo como critérios diagnósticos:

a) Uma forte e persistente identificação com o gênero oposto (não meramente um desejo de obter quaisquer vantagens culturais percebidas pelo fato de ser do sexo oposto);

b) Desconforto persistente com seu sexo ou sentimento de inadequação no papel de gênero deste sexo;

c) A perturbação não é concomitante a uma condição intersexual física;

d) A perturbação causa sofrimento clinicamente significativo ou prejuízo no funcionamento social ou ocupacional ou em outras áreas importantes da vida do indivíduo. (: 29) (Grifos nossos).

No Brasil, a normativa que traz os parâmetros para diagnosticar alguém é a Resolução do Conselho Federal de Medicina - CFM, nำ1.955/2010²5.

Art. 1ำ Autorizar a cirurgia de transgenitalização do tipo neocolpovulvoplastia e/ou procedimentos complementares sobre gônadas e caracteres sexuais secundários como tratamento dos casos de transexualismo.

Art. $2^{\circ}$ Autorizar, ainda a título experimental, a realização de cirurgia do tipo neofaloplastia.

Art. 3ํㅡㄹ a definição de transexualismo obedecerá, no mínimo, aos critérios abaixo enumerados:

1) Desconforto com o sexo anatômico natural;

2) Desejo expresso de eliminar os genitais, perder as características primárias e secundárias do próprio sexo e ganhar as do sexo oposto;

3) Permanência desses distúrbios de forma contínua e consistente por, no mínimo, dois anos;

4) Ausência de outros transtornos mentais.

Art. 4ำ Que a seleção dos pacientes para cirurgia de transgenitalismo obedecerá a avaliação de equipe multidisciplinar constituída por médico psiquiatra, cirurgião, endocrinologista,

\footnotetext{
${ }^{24}$ Atualmente o DSM está em sua $5^{a}$ versão. Entretanto, nessa dissertação trabalhou-se com a versão anterior de número 4. Para maiores informações sobre o DSM-5 ver em:

http://www.dsm5.org/about/Pages/Default.aspx

Último acesso em: 27/02/15.

Ainda sobre DSM-V, Rodrigo Borba no artigo "Sobre os obstáculos discursivos para a atenção integral e humanizada à saúde das pessoas transexuais" (2014), faz uma crítica à mudança dos termos entre as trocas de versões. Nessa edição, saí de cena o "Transtorno de Identidade de Gênero" e entra a "Disforia de Gênero". Com esse implemento, o DSM-V pretenderia "a diminuição da carga estigmatizante carregada pela designação 'transtorno", numa tentativa "aparentemente despatologizante." Porém, para o autor, a alteração dos termos não retira o caráter patológico, mas ao contrário, "o conceito de disforia abrange uma gama maior de sentimentos de desconforto de gênero, o que amplia seu escopo." (NR: 69).
}

\footnotetext{
${ }^{25}$ Ver em: http://www.portalmedico.org.br/resolucoes/CFM/2010/1955 2010.htm
} Último acesso em: 27/02/15. 
psicólogo e assistente social, obedecendo os critérios a seguir definidos, após, no mínimo, dois anos de acompanhamento conjunto:

1) Diagnóstico médico de transgenitalismo;

2) Maior de 21 (vinte e um) anos;

3) Ausência de características físicas inapropriadas para a cirurgia.

(Grifos nossos).

Embora com algumas diferenças de entendimento entre os postulados médicos trazidos pelo CID (e pela comunidade de endocrinologistas, cujo "pai" e maior expoente é o médico americano Harry Benjamim ${ }^{26}$ ) e aqueles elencados pela psiquiatria e psicologia (sobretudo os norteamericanos da Associação Psiquiátrica Americana - APA)representados no DSM-IV, para o que se poderia chamar de "ciências da saúde"27, a "tradução" da demanda por cirurgias de adequação genital é a categoria médico-patológica "transexualismo" ou "transtorno de identidade de gênero". Nos manuais acima, há a afirmação de que o sofrimento se daria em razão do descompasso existente entre o desejo de viver e ser reconhecida/o como do sexo/gênero oposto ao da genitália (sexo) que se nomeia ora de "transexualismo", ora de "transgenitalismo", como se ambas as situações: desejar ser de outro sexo/gênero e ser "transexual" fossem a mesma coisa.

Os trechos grifados mostram que a questão central é essa: para resolver o "desejo de viver e ser aceito com um membro do sexo oposto"; a "identificação com o gênero oposto"; o "desconforto persistente com seu sexo"; o "sentimento de inadequação no papel de gênero deste sexo"; o "desejo expresso de eliminar os genitais [...] e ganhar as do sexo oposto", as/os aspirantes deverão ser diagnosticadas/os por equipe interdisciplinar ou multidisciplinar, atestando por intermédio de um laudo ser aquela/e portador de "transexualismo", cuja indicação será ou não pela cirurgia de "transgenitalismo" (do tipo neocolpovulvoplastia, para as mulheres nascidas com pênis; e neofaloplastia, para os homens nascidos com vagina e vulva) e demais "procedimentos secundários" ${ }^{28}$. Em outras palavras: quem

\footnotetext{
${ }^{26}$ O falecido médico empresta o nome a uma instituição interdisciplinar voltada à "saúde de transgêneros". Ver em: http://www.wpath.org/site home.cfm Último acesso em 27/02/15.

${ }^{27}$ Expressão usada para abarcar os saberes médico, psiquiátrico, psicológico, de enfermagem entre outros. Naqueles campos a morfologia têm precedência à sujeita.

${ }^{28}$ Ver as portarias do "Processo transexualizador do SUS" mais adiante.
} 
desejar se submeter às cirurgias terá de ser clinicamente diagnosticada/o como "transexual" para só então efetivamente obter a autorização ${ }^{29}$ para as intervenções.

Não é objeto desse estudo um levantamento que se pretenda histórico sobre as terminologias clínicas acima, pois a existência normativa daquelas categorias prescinde de preocupações etiológicas. $O$ fato é que o discurso que se pode chamar de médico-jurídico está positivado, normatizado e regulamentado. Além disso, é um hábil instrumento categorizador e, na atualidade em muitos países (e no Brasil inclusive), a única forma de acesso às cirurgias.

\subsection{Da submissão à luta pela cirurgia.}

Diversos autores já trabalharam com a via da denúncia das arbitrariedades nas classificações médico-psicológicas acima, na visão autoritária, com o uso do saber-poder, do que se nomeia de "transexualidade" nas ciências sociais $^{30}$. O advogado Ábiner Gonçalves ${ }^{31}$, no campo do direito, afirma textualmente não se tratar de uma doença, também não se configura como identidade propriamente dita, mas sim uma "experiência". A vivência de um processo físico e jurídico é o que o autor chama de "vivência da transexualidade", sendo mulheres ou homens, identidades autoconclamadas pelas sujeitas e sujeitos.

\footnotetext{
${ }^{29}$ No Brasil pela Rede Pública e grande parte das clínicas privadas não se realizam tais cirurgias sem uma autorização expressa de médico ou equipe. Não basta a vontade da sujeita ou do sujeito, apenas.

${ }^{30}$ Ver a tese de BENTO, "A reinvenção do corpo: sexualidade e gênero na experiência transexual" (2003), onde pretende denunciar os discursos e as práticas médico-psicológicas na construção do "verdadeiro transexual" em dissonância com as pessoas transexuais (termos da autora) inscritas no Hospital de Clínicas de Goiânia e as/os militantes de uma ONGs de transexuais na cidade de Valência na Espanha. Já TEIXEIRA em, "Vidas que desafiam corpos e sonhos: uma etnografia do construir-se outro no gênero e na sexualidade" (2009) acompanha algumas/ns participantes do extinto Programa de Transgenitalização coordenado pela Promotoria de Justiça Criminal de Defesa dos Usuários dos Serviços de Saúde (Pró-Vida) subordinada ao Ministério Público do Distrito Federal e Territórios (MPDFT) na tentativa de compreensão da atuação do saber-poder jurídico na autorização ou denegação dos casos de cirurgia. Os argumentos das autoras serão mais detalhados a frente.

${ }^{31}$ Para o autor que entrevistou algumas sujeitas, a terminologia que melhor reflete a fala de vida seria "vivência da transexualidade". Ver em: "Mulheres! Patologia não é identidade", Escola da Magistratura do DF, 2012.
} 
Cumprindo reivindicações de movimentos sociais, no ano de 2008, inaugura-se no âmbito do Sistema Único de Saúde (SUS) o chamado "Processo Transexualizador"32, com as portarias ำ1.707/2008, № 457/2008 e a mais recente, no $2.803 / 2013^{33}$. Anteriormente, a Saúde Pública só custeava os procedimentos via ação judicial ou em caráter experimental nos Hospitais Universitários vinculados a universidades federais. Naqueles documentos, houve o deslocamento da identidade de "transexualismo" dos manuais CID e DSM-IV para "pessoa transexual" ou "indivíduo transexual":

A cirurgia de transgenitalização deve ser concebida como um dentre outros recursos terapêuticos dos quais dispõe 0 indivíduo transexual em seu processo transexualizador. (grifos nossos) ${ }^{34}$.

Se o processo de (auto)identificação da sujeita diante do saber-poder médico-jurídico e as negociações com as categorias "transexuais" com o objetivo da cirurgia de adequação genital é extremamente desigual e conflituoso, conseguir realizar as cirurgias no Brasil pelo Sistema Único de Saúde é verdadeiro martírio, caminho longo e de extremo sofrimento. Mesmo com todo o aparato técnico e legal operante, encontram-se raras experiências de pessoas que obtiveram êxito em se operar dentro dos prazos legais (mínimo de dois anos de acompanhamento

\footnotetext{
${ }^{32} \mathrm{~A}$ referência ao nome acredita-se, deve-se ao conjunto de procedimentos clínicos disponibilizados pelo Estado para a "solução" do problema. Não encontramos nenhuma justificativa ou artigo que especifique mais esse termo.

${ }^{33}$ Portaria MS/GM n 1.707/2008, "Institui, no âmbito do Sistema Único de Saúde (SUS), o Processo Transexualizador, a ser implantado nas unidades federadas, respeitadas as competências das três esferas de gestão". Ver em:

http://bvsms.saude.gov.br/bvs/saudelegis/gm/2008/prt1707 1808 2008.html

Último acesso em 04/11/14.

Portaria MS/GM no 457/2008, regulamenta a Portaria 1.707, bem como define as Unidades de Atenção Especializadas (vulgarmente conhecidos como "Centros de Referência", Hospital Universitário onde se realizam as cirurgias pelo SUS) e demais providências. Ver em:

http://cnes.datasus.gov.br/Portarias\%5CPORTARIA\%20N\%C2\%B0\%20457\%20de\%2019\%20de\%20 Agosto\%20de\%202008.pdf

Último acesso em: 04/11/14.

Portaria MS/GM n².803/2013, "redefine e amplia o Processo Transexualizador no Sistema único de Saúde", Ver em:

http://bvsms.saude.gov.br/bvs/saudelegis/gm/2013/prt2803 1911 2013.html

Último acesso em: 04/11/14.

${ }^{34}$ Trecho da Portaria no $1.707 / 2008$ GM/MS.
} 
multidisciplinar, de acordo com o CFM) ou com a melhor tecnologia cirúrgica ${ }^{35}$. Num dos Hospitais referenciados pelas portarias a média é de 3,5 anos de espera. Noutro, por volta de cinco anos. Um das interlocutoras soube por amigas que no Hospital de Goiânia/GO, a cirurgia poderia dar complicações, pois um dos médicos que operava com regularidade não era especialista nas técnicas. Em São Paulo/SP, pelo Sistema Único de Saúde, outra interlocutora aguardou 15 (quinze!!) anos pela cirurgia ocorrida apenas em 2011.

A Portaria GM/MS 457/2008 elenca as quatro Unidades de Atenção Especializadas no Brasil. São elas: Hospital de Clínicas de Porto Alegre/RS; Hospital Pedro Ernesto no Rio de Janeiro/RJ; Hospital das Clínicas de São Paulo/SP e Hospital Universitário de Goiânia/GO. Entretanto, apenas o HCPA de Porto Alegre/RS mantém os protocolos como prescrevem as normativas. Os demais de tão lotados não recebem mais pacientes. Para os estados da federação que não contam com atendimentos, as sujeitas devem procurar o posto de saúde ou os núcleos de atendimento fora de domicílio ${ }^{36}$ para iniciar a via crucis de idas e vindas até a conclusão do processo com a adequação genital. Em Brasília não se realizam as cirurgias por falta de equipe médica. Há quase quinze anos o "Programa Transexuais", grupo terapêutico ${ }^{37}$ está precariamente instalado no Hospital Universitário de Brasília (HUB) por insistência de uma profissional da área de psicologia, sem o devido reconhecimento da instituição. Tentamos entrevistar a psicóloga responsável pelo grupo, entretanto apesar da diversidade dos contatos (emails, telefonemas, recados em rede social) ela não respondeu às tentativas de contato. Estimamos que entre 100 a 200 sujeitas e sujeitos participaram daquele grupo. Houve um acordo verbal entre a psicóloga responsável pelo grupo do HUB e a coordenadora do "Projeto Transexualismo" alocado no Hospital Universitário de

\footnotetext{
${ }^{35} \mathrm{De}$ acordo com as interlocutoras, existem diversas técnicas. No Brasil duas ou três variações da técnica conhecida entre os médicos como "inversão peniana" são as mais usadas.

${ }^{36}$ Núcleo de Regulação de Tratamento Fora do Domicílio (TFD/DF) está previsto nas disposições da Portaria Federal no 055, de 24 de fevereiro de 1999 da Secretaria de Assistência à Saúde/Ministério da Saúde. Em Brasília/DF é o órgão vinculado à Secretaria de Saúde do DF responsável por encaminhar as usuárias do SUS aos centros de referências especificados nas Portarias do "Processo transexualizador".

${ }^{37}$ Pelas Resoluções do CFM e Portarias do SUS as sujeitas e os sujeitos que desejarem as cirurgias deverão passar por atendimento multidisciplinar que contemple em suas especialidades psicoterapia de grupo para a troca de experiências entre as e os participantes.
} 
Goiânia/GO ${ }^{38}$ que propiciou que algumas sujeitas e alguns sujeitos fossem operados no HUG. Não se tem notícias se ainda há sujeitas ou sujeitos enviados para Goiânia. De acordo com informações do TFD ${ }^{39}$, por descaso ou desinteresse dos gestores em saúde pública federal e local, apenas o Hospital de Clínicas de Porto Alegre/RS ainda recebe novas usuárias, tanto da região sul do País, quanto de todos os estados da federação. Assim, em todo o País, de todos os hospitais credenciados e legalmente habilitados a realizar as cirurgias pelo SUS, apenas o de Porto Alegre/RS tem funcionado.

Duas das interlocutoras do trabalho estão aguardando atendimento com o objetivo de realizar a cirurgia pela rede pública de saúde. Malévola moradora de Brasília, espera há três anos apenas para ter a primeira consulta. Após iniciar os protocolos legais, com um mínimo de dois anos de idas e vindas quinzenais, ela estará autorizada a realizar as cirurgias. Úrsula - a Feiticeira do Mar moradora de Santa Catarina/SC está inscrita no Hospital de Clínicas de Porto Alegre/RS há cerca de seis anos e conta os dias para a operação. Ambas as trajetórias serão contadas nos próximos capítulos.

Uma parcela de sujeitas que reivindicam as cirurgias e possuem condições financeiras buscam atendimento em clínicas especializadas no Brasil e no exterior. No País uma das mais conhecidas fica na cidade de Jundiaí em São Paulo/SP coordenada pelo cirurgião plástico Dr. Jalma Jurado que durante anos chefiou a equipe de urologia do Hospital de Clínicas de São Paulo/SP e ainda hoje é uma importante referência no tema. Nas consultas, o Dr. Jurado costuma apresentar fotos das cirurgias na tela do computador, enquanto discorre sobre a técnica ${ }^{40}$. Ao final da apresentação, mostra uma fotografia de um casal, uma moça em vestido de noiva e um rapaz trajando fraque, afirmando que "depois de tudo você pode

\footnotetext{
${ }^{38}$ Para maiores informações, a coordenadora se chama Dra. Mariluza Terra e recentemente promoveu um debate sobre o tema. Ver em: https://www.hc.ufg.br/n/24143-fm-promove-simposio-sobreredesignacao-sexual

Último acesso em: 27/02/15.

${ }^{39}$ Como uma das interlocutoras dessa dissertação está inscrita no TFD não se mencionará mais detalhes sobre o informante da unidade, preservando-se assim a identidade da sujeita.

${ }^{40}$ Uma das sujeitas relatou-nos essa cena durante uma consulta particular com aquele médico. Entretanto, pediu-nos que não detalhasse nem a situação, nem os dados.
} 
conquistar a felicidade!" Para arrematar, indica sua secretária para tratar dos assuntos práticos e financeiros. Na proposta de valor superior a 20 mil reais pagos a vista, a sujeita é operada no período da manhã, repousando na clínica e no dia seguinte, deverá procurar um hotel nas redondezas por aproximadamente uma semana. Caso haja alguma emergência, o médico deve ser avisado. Entretanto, dada à delicadeza da intervenção, como se verá na história de Bruxa Malvada do Oeste, pode haver complicações que talvez não esperem um deslocamento, como uma hemorragia ou insuficiência cardiorrespiratória. Nesse caso, a felicidade ofertada pelo médico, pode custar-lhe-á vida. $\mathrm{Na}$ atualidade, o respeitável cirurgião está proibido de realizar cirurgias por decisão liminar do Conselho Regional de Medicina de São Paulo, em razão de diversos casos de mutilações, erros e insucessos. ${ }^{41}$

Outro exemplo de sucesso técnico-profissional é o cirurgião-urologista com especialidade na Bélgica, Dr. Eloísio Alexsandro da Silva que atende tanto no Hospital Pedro Ernesto (UERJ) ${ }^{42}$ quanto em sua clínica na Barra da Tijuca, no Rio de Janeiro/RJ. Atualmente, a tabela de honorários do cirurgião gira entre 20 e 70 mil reais a depender das condições financeiras da paciente que ele avaliará nas primeiras consultas. Se ela não tiver condições, não tem importância, pois o doutor opera também pelo Sistema Único de Saúde em um dos "Centros de Referência", que funciona dentro da UERJ. O único, porém é que aquele centro possui a segunda maior fila de candidatas e candidatos com a média de espera avaliada entre cinco e seis anos. O urologista também publicou um livro, aos modestos valores de $R \$ 183,00$ - $R \$ 242,00$, cujos objetivos, são: "servir como um referencial teórico básico" e "[...] um estímulo à reflexão por meio de informações de alta qualidade escritas por especialistas reconhecidos nas suas diversas áreas." ${ }^{43}$

\footnotetext{
${ }^{41}$ Ver em:

http://www.ji.com.br/noticias-9233-medico-que-atende-em-jundiai-e-impedido-de-fazer-cirurgias-detroca-de-sexo

http://ongabcds.com.br/clinica-jalma-jurado-fechada-por-erros-em-cirurgias-de-redesignacao-sexual/ Último acesso em: 27/02/15.

${ }^{42}$ Ver em: http://urologia.ueri.br/site/1/servicos.php Último acesso em: 27/02/15.

${ }^{43}$ Ver em:

http://www.buscape.com.br/transexualidade-principios-de-atencao-integral-a-saude-eloisioalexsandro-da-silva-8572889175.html\#precos
} 
No exterior, diversos países tem tradição nas cirurgias. Para citar alguns exemplos: Marrocos, Inglaterra, EUA, França, Bélgica, Holanda, Dinamarca, Espanha e, aquele com mais clínicas especializadas nas diversas técnicas: a Tailândia. Todos veem nos "laudos" algum nível de segurança para operar. $\mathrm{Na}$ ausência de um diagnóstico "transexual", o valor pode até subir, como ocorre em algumas clínicas na Tailândia. Mas para alguns não há possibilidades de fazer a cirurgia sem que um documento autorize. Em nosso entender, tal cuidado não se deve antes a alguma preocupação com a saúde da sujeita, mas sim como instrumento de salvaguarda do médico ou da equipe diante de uma possível responsabilização judiciária, em caso de insatisfação. A resposta pode estar em São José do Rio Preto, interior de São Paulo, no cirurgião que mesmo com diversos processos por erros ${ }^{44}$, continua a realizar essas cirurgias cobrando "módicos" três mil reais às desavisadas que o procuram.

Chamamos neste trabalho de "especialistas da vida alheia" os indivíduos, grupos ou instituições cujo conhecimento supostamente superior e especializado acerca das necessidades e anseios de outrem em razão de privilegiada posição social, política, econômica, tecnologia, entre outras os torna "os mais aptos" para nomear, classificar, categorizar, atestar, deferir e permitir que determinados sujeitas ou sujeitos possam ou não fazer com seus corpos aquilo que desejam. $O$ uso ou abuso dos mecanismos (institucionais) de poder tornam essas "autoridades" credenciadas como únicas capazes de emitir decisões finais. A palavra oficial e última da qual não cabem manifestações simplesmente porque são autoridades, logo não há argumentos contrários suficientes ${ }^{45}$. Os "especialistas da vida alheia" são: médicos, psiquiatras, psicólogos, assistentes sociais, promotores de justiça,

\footnotetext{
E também:

http://www.casasbahia.com.br/livros/LivrodeMedicinaeSaude/LivrosdeMedicina/Transexualidade-

Principios-de-Atencao-Integral-a-Saude-Eloisio-Alexsandro-da-Silva-1764063.html

Último acesso: 27/02/15.

${ }^{44}$ Ver em: $h$ ttp://www.jb.com.br/pais/noticias/2011/03/03/pioneiro-em-cirurgias-de-troca-de-sexo-sera-
investigado-em-sp/
Último acesso em: 27/02/15.

${ }^{45}$ Luís Roberto Cardoso de Oliveira, no trabalho "A dimensão simbólica dos direitos e a análise de conflitos" faz uma crítica ao que chama de "argumentos de autoridade" na forma como os juízes decidem nos sistemas de tradição civilista, em especial no caso brasileiro, em oposição aos argumentos que podem ser debatidos, refutados ou acordados nos sistemas de tradição commom law, como referência o sistema estadunidense no que tange à diferenciação conceitualmente clara entre "provas", "indícios" e "evidências" que no Brasil não são diferenciadas.
} 
magistrados, entre outros, (re)produtores do saber-poder no que se refere aquilo que se identifica como "transexualidade". A indiscutibilidade da autoridade de médicos e outros agentes, sobretudo das áreas da saúde, fabricam realidades como se verá no próximo tópico com Laqueur.

\subsection{A diferenciação social e política dos sexos.}

Thomas Laqueur (2001) na obra "Inventando o sexo: corpo e gênero dos gregos à Freud" aborda os aspectos sociais e políticos nas concepções de diferenciação entre os sexos. Com o argumento de que o gênero (os marcadores culturais) antecede o sexo (o corpo $)^{46}$, no que chama de "modelo do sexo único" e de "dimorfismo radical", traça um detalhado panorama dos últimos dois mil anos da história ocidental.

Laqueur começa o estudo explanando:

Durante milhares de anos acreditou-se que as mulheres tinham a mesma genitália que os homens, só que - como dizia Nemesius, bispo de Emesa, do século IV - "a delas fica dentro do corpo e não fora". Galeno, que no século II d.C. desenvolveu o mais poderoso e exuberante modelo da identidade estrutural, mas não espacial dos órgãos reprodutivos do homem e da mulher, demonstrava com detalhes que as mulheres eram essencialmente homens, nos quais uma falta de calor vital - de perfeição - resultara na retenção interna das estruturas que no homem são visíveis na parte externa (2001: 16)

Essa ideologia do "modelo de sexo único", com os corpos masculinos e femininos em versões hierarquizadas, verticalmente ordenadas de um único sexo (o feminino uma cópia menos perfeita do masculino) perdurou da antiguidade clássica até o final do século XVII, quando foi substituído pela visão de "dimorfismo radical", diferenciando sexualmente homens e mulheres não apenas no corpo, mas também na alma. Nas palavras do autor:

A visão dominante desde o século XVIII, embora de forma alguma universal, era que há dois sexos estáveis, incomensuráveis e opostos, e que a vida política, econômica e cultural dos homens e das mulheres, seus papeis de gênero, são de certa forma baseados nesses "fatos". A biologia - o corpo estável, não-histórico e sexuado - é compreendida como o fundamento epistêmico das afirmações consagradas sobre a ordem social(: 18).

\footnotetext{
${ }^{46}$ Mais a frente o autor declara: "historicamente, as diferenciações de gênero precedem as diferenciações de sexo" (: 75).
} 
Com o lluminismo houve o crescente interesse na busca por distinções anatômicas e fisiológicas concretas entre homens e mulheres que sustentassem as mudanças epistemológicas e políticas que rapidamente se desenvolviam, tornando possível o fundamento biológico do que seria dito como masculino e feminino.

Entram em cena, fatores como: religião; casamento como um contrato; conservadorismo pós-revolucionário; feminismo pós-revolucionário; divisão sexual do trabalho; entre outros, fazendo com que as diferenças se tornassem politicamente importantes. Então, foi a política entendida como competição por poder, criadora das formas de construir o sujeito e as realidades sociais (: 21-23). Laqueur encara e contextualiza o problema da seguinte forma: "o sexo, tanto no mundo do sexo único como no de dois sexos, é situacional; é explicável apenas dentro do contexto da luta sobre gênero e poder" (: 23$)$.

Nos cenários sociais, a supremacia do poder do homem sobre a mulher tinha de repousar em alguma constatação de essência metafísica, superior, incontestável que se refletisse nos corpos. Pois, os pares de oposição socialmente forjados como paternidade/maternidade; macho/fêmea; homem/mulher; cultura/natureza, entre outros, "[...] eram vistos em um corpo que em si não fazia essas distinções com nitidez." (: 75).

Surge, assim, na Renascença a Ciência representada pelos médicos e anatomistas ${ }^{47}$, com seu poder de descobrir e revelar aos demais as diferenças radicais entre os corpos tanto no modelo de sexo único, como no "mundo de dois sexos" (: 116). E nesse sentido:

\footnotetext{
${ }^{47}$ Mais a frente o autor salienta a importância dos médicos na decisão final quanto à determinação do sexo de um indivíduo "em casos difíceis", de "forma que pudesse ajustar-se à pessoa em categorias claras e não-ambíguas de gênero". O autor prossegue citando o médico renascentista Colombo e sua preocupação com os hermafroditas, cuja determinação sexual apenas levaria em conta a "superabundância" da substância que o ser recebera, sintetizado pela capacidade em gerar descendentes: se "eles são mais apropriados ou considerados mais apropriados a formar seres humanos ou a receber um." Porém, ao contrário da mentalidade moderna, a possibilidade de concepção da mulher era pouco ou nada considerada. Importava mais a paternidade: ser masculino significava então ser pai, ser autor de uma vida. "Quanto mais a criatura se aproximava da 'criatividade', mais masculina ela era". (: 170-171). A definição do sexo a partir estritamente das genitálias só ocorre a partir do século XIX, nas palavras do famoso médico-legista francês Ambroise Tardieu: "uma pura questão de fato, que pode e deve ser solucionada pelo exame anatômico e fisiológico da pessoa em questão." (: 172).
} 
Ter um pênis não faz o homem, assim como, para citar Feste, "cucullus non facit monachum" (o hábito não faz o monge). Porém homens e mulheres foram destacados pela configuração de seus corpos - ter um pênis do lado de fora ou do lado de dentro - para seus necessários papeis procriativo se vários outros papeis específicos do gênero (: 152).

Assim, o sexo (inclusive como se entende hoje) é de ordem hierárquica, superior, cósmica, situado num plano incontestável como projeto de Deus para a conservação e perpetuação da espécie humana (: 153).

Ao menor perigo sempre possível de subversão dessas "verdades imutáveis", a Ciência deve responder com argumentos racionais na afirmação da ahistoricidade em todo e qualquer contexto, para quaisquer sujeitas ou sujeitos, com objetivo da manutenção de uma ordem social que, como visto, nem sempre foi assim. Aos transgressores: as punições severas variavam de descrédito social, perda de bens ou capacidade de geri-los, condenação à morte ou a extirpação do órgão genital e o exílio permanente por "desejo imoral"48.

Nesse sentido, a partir da compreensão das forças operantes nas reflexões de Laqueur pode-se pensar que a demanda das sujeitas, como se verá, é pelo reconhecimento social e político de serem mulheres, independentemente dos atributos corporais. As questões físicas serão superadas com as cirurgias e as jurídicas, por óbvio, com decisões judiciais. A atual hegemonia das ciências médicopsicológicas pode nunca vê-las como mulheres, em razão dos postulados modernos das "diferenças incomensuráveis", que como se viu foram por centenas de anos política e socialmente contingenciadas. Entretanto, essa não parece ser uma preocupação das sujeitas após a obtenção do que consideram o necessário para a "plenitude de ser mulher" 49 .

De todo modo, pode-se afirmar com certeza que quaisquer sujeitas que desejem ou necessitem realizar as cirurgias de adequação genital no Brasil e em

\footnotetext{
${ }^{48}$ Laqueur narra a história de Henrika Schuria, do século XVII que fora definida como "tríbade", "uma mulher de comportamento masculino que se cansou do seu sexo", alistando-se no exército e passando a viver como homem até o momento em que foi descoberta tendo relações sexuais com outra mulher e condenada pela ousadia em achar que poderia ser homem. (:173).

${ }^{49}$ Afirmação feita por Maga Patalógica, como mais a frente se verá.
} 
muitos outros países terá necessariamente que se submeter aos parâmetros médicos-jurídicos, pois na ausência da autenticidade, via laudo, atestando ser "transexual" ou da não compreensão de tratar-se de um "transtorno de identidade de gênero", haverá negativa do pleito. Logo, o problema não é ser ou não "transexual", mas demandar uma cirurgia que adequará a genitália à identidade de mulher da sujeita.

Mesmo nas pessoas que eventualmente se identificarem como "transexuais" o pedido, a queixa, a demanda não parece ser o reconhecimento como transexual, mas ser aceita como mulher ou do gênero feminino. Assim, se está diante de um falso problema, na medida em que o que se busca é a cirurgia e não necessariamente ser "transexual", portadora de "transexualismo" ou reivindicando a transexualidade como identidade. Porém, a sujeita não poderá questionar esse axioma, pois a visão do saber-poder médico-jurídico é hegemônica e autoritária. Cria realidades e estabelece verdades absolutas, como dogmas.

\subsection{A proposta de revisão da OMS.}

Está em estudo com vários grupos de trabalho entre os "especialistas" em diversas partes da América Latina, Índia, Líbano e África do Sul (regiões abrangidas pela OMS) e ainda Suécia, Holanda, Reino Unido uma proposta de alteração e realocação da categoria "F64.0" no compêndio da Classificação Internacional de Doenças da Organização Mundial de Saúde (CID11/OMS) a ser debatida ainda em 2015. Na nova versão, o "transtorno de identidade de gênero" e o "transexualismo" passarão a ser uma "Discordância" ou "Incongruência de Gênero na Adolescência e Idade Adulta", saindo da atual topografia de "Transtornos Mentais e Comportamentais" para uma categoria ainda não existente de "Transtornos Sexuais e outras Condições relacionadas à Sexualidade".

\footnotetext{
${ }^{50}$ Caracterizada por uma "notável e persistente incongruência entre a experiência de gênero de um indivíduo e o seu sexo designado".
} 
Na prática tal mudança significará deixar as categorias mais amplas para abarcar quaisquer indivíduas que reivindicam modificações corporais ou jurídicas sem que necessariamente se identifiquem como "transexuais". Importará também não na total despatologização, mas numa pressão médico-psicológica bem menor sobre as sujeitas e os sujeitos. Tal iniciativa teve como demanda os movimentos "trans" internacionais ${ }^{51}$. A preocupação da OMS parece ser de que maneira tais modificações irão impactar o acesso às modificações corporais e jurídicas nesses países para só então, defendê-las na Assembleia Mundial de Saúde instância máxima nas políticas de saúde em âmbito mundial.

Ponto fundamental é, caso haja a modificação das categorias médicopsicológicas, certamente se refletirá no Judiciário. Assim, os atores jurídicos terão de embasar suas decisões de outras formas, pois a certeza do "transexual verdadeiro" se diluirá em diversas outras identidades e cada uma delas poderá ter acesso às cirurgias e demais intervenções. Os hospitais credenciados poderão também, além de testemunhar um aumento significativo na demanda, verem-se às voltas com outras identidades recorrendo às tecnologias para modificação dos corpos, como exemplo, as travestis, público ao que parece inexistente nessas questões.

\section{O Poder Judiciário e as demandas de alteração de prenome e substituição de gênero.}

Para se alterar o prenome ou o gênero nos documentos civis no Brasil nos casos desse trabalho, as sujeitas ou os sujeitos deverão entrar com processo judicial necessariamente com a presença de advogada/o que pelo entendimento local, poderá cumular os pedidos ou não, ser antes ou depois da cirurgia. Essa ação passará pelos ritos judiciais ${ }^{52}$ e terminará com uma sentença que declarará

\footnotetext{
${ }^{51}$ Há uma campanha internacional promovida por organizações sociais com o objetivo de despatologizar (retirar o caráter de doença ou patologia) as categorias trans "Stop Trans Pathologization". Maiores informações em: http://www.stp2012.info/old/pt

Último acesso em: 27/02/15.

${ }^{52}$ Aqui no Distrito Federal, por exemplo, em se tratando de alteração de prenome na Vara de Registros Públicos de Brasília/DF as demandas costumam ser bem céleres se comparadas às das varas de família, onde se pleiteará as alterações de gênero. Uma das explicações pode ser a comparação entre os ritos: no primeiro caso, como se verá, nas ações de mudança de prenome se discute única e exclusivamente se a sujeita ou o sujeito são reconhecidas/os por nome distinto
} 
juridicamente uma situação fática provendo, em caso afirmativo, a modificação do prenome e/ou do gênero.

No Poder Judiciário, os casos de alteração de prenome civil e substituição do gênero contidos no assento do registro civil ${ }^{53}$ seguem, segundo informações do atual Juiz Titular da Vara de Registros Púbicos de Brasília/DF, as recomendações do Ministério Público, nos pareceres ou cotas ministeriais. Em outras palavras, se o promotor se convence pela alteração de prenome ou gênero, o juiz fundamenta a decisão em consonância com os argumentos do promotor de justiça. Caso o promotor não oficie pela alteração pretendida, frequentemente o julgador irá se filiar à decisão, sendo na prática, uma exceção o magistrado discordar do promotor ${ }^{54}$.

As representações dos juízes e promotores sobre as sujeitas que demandam pleitos de modificação de prenome e gênero são conflitantes e por vezes desconectadas da realidade. Pelas falas e sentenças, há igualmente dificuldades em "traduzir" os pedidos da ação quando da alocação na categoria médica "transexual". Parece não estar claro quem são as sujeitas, se "transexuais", "transgêneros" ou "mulheres", embora saibam que a demanda seja pelo reconhecimento de ser mulher ou do gênero feminino, antes ou depois das cirurgias, nos documentos civis. Essa

daquele inscrito nos documentos civis; no segundo, se debaterá se houve ou não alterações no corpo compatíveis com status de gênero diferente daquele dos registros e se tal modificação trará repercussões familiares, tais como maternidade/paternidade ou casamento anterior às alterações. Uma vez no Poder Judiciário, não há como precisar a duração ou o êxito garantido de tais processos. Vale ressaltar que no caso do DF não se altera o gênero sem a alteração de prenome e 0 entendimento local dos juízes é que para se modificar o gênero nos documentos deve-se necessariamente ter realizado a cirurgia.

${ }^{53}$ Grosso modo, Registro Civil de Pessoas Naturais é um dos vários Livros onde se grafam os principais atos e fatos da vida civil, tais como: nascimentos, casamentos, mortes, etc. Trata-se de documento originário, sigiloso e interno aos expedientes cartoriais. Averbação é o ato de anotar no Registro Civil determinada modificação de fato ou de direito. A Certidão de Nascimento é uma "cópia", certificação, das informações e dados contidos no Registro para fazer prova de situação jurídica. Ex: filiação, nome de solteira, etc. O Registro Civil não é documento aberto ao público em geral, mas as certidões advindas dele, sim. Para se ter acesso a informações contidas naquele livro faz-se necessário autorização judicial, bem como comprovação de interesse relevante.

\footnotetext{
${ }^{54} \mathrm{Na}$ etnografia sobre os juizados da Lei Maria da Penha, "Em briga de marido e mulher o Judiciário mete a colher: qual a "medida"? Uma etnografia sobre as práticas judiciárias "conciliatórias" de conflitos em Juizados de Violência Doméstica do Distrito Federal", Alessandra De la Vega Miranda analisa que é muito comum magistrado e promotor de justiça trabalhem em conjunto para determinado desfecho num processo judicial, fazendo "acordos", muitas vezes à revelia das partes. Ver em: http://hdl.handle.net/10482/17335

Último acesso em 1/03/15.
} 
dificuldade de sintonia pode se dar em dois caminhos: a) os processos de redução a termo, característicos do sistema judicial brasileiro como na descrição de Cardoso de Oliveira ${ }^{55}$, resumidamente, espécie de "filtro" processual concatenando os "fatos" (descrição com pretensão de objetividade da situação ocorrida) com o "direito" (descrição da lei ou tipos legais que comprovem o direito ou a denegatória dele); b) questões subjetivas ou posições morais do magistrado.

O diálogo com o juiz de direito da única Vara de Registros Púbicos de Brasília/DF ocorreu em dois momentos: o primeiro, na entrevista pessoal em 30/05/14 e o segundo em resposta às perguntas enviadas previamente via e-mail, em novembro de 2014. Escolhemos esse magistrado porque ele havia atuado em diversas ações de alteração de prenome e, como só existe uma Vara de Registros Públicos em Brasília, necessariamente ele seria o julgador nessas causas. No primeiro encontro, fui recebida com certa desconfiança e o magistrado pediu para elaborar melhor as respostas as minhas questões. Dessa ocasião guardo apenas as anotações no caderno de campo. O segundo momento, ele alegou não ter tempo disponível para entrevistas pessoais, por isso pediu-me que the enviasse e-mail com perguntas e ele as responderia em seguida.

Para iniciar, perguntei-Ihe o número aproximado de processos de alteração de prenome em sujeitas e sujeitos cuja (auto)percepção destoava do gênero contido nos documentos civis. Contou-me que embora o sistema do TJDFT não faça distinção desse tipo de processo por assunto, acredita ter sentenciado em um número próximo de cinquenta feitos desde que fora removido em 2009 para aquela vara. Perguntei-Ihe em sua visão por quais motivos as pessoas buscam alterar o prenome nessas situações. Respondeu-me que "os indivíduos transgêneros" sofrem diversos preconceitos, discriminações inimagináveis. Para ele, a alteração de prenome é um "resgate da dignidade", já que o nome registral não as identifica socialmente, esse descompasso gera constrangimentos à pessoa. Em

\footnotetext{
${ }^{55}$ Na obra "Honra, Dignidade e Reciprocidade" (2004: 7), Luís Roberto Cardoso de Oliveira estuda os processos de pequenas causas na realidade estadunidense comparando-os ao caso brasileiro. Nesse último modelo em específico, com o advento dos Juizados Especiais Cíveis está normatizado que as petições dirigidas ao juízo sejam "reduzidas a termo" na secretaria ou por defensor, advogado ou núcleo de prática, sob pena de não conhecimento. Ver: parágrafo $3^{\circ}$, do artigo 14 da lei ํo 9.099/95 (Lei dos Juizados Especiais).
} 
suas palavras, a sentença de deferimento "é apenas uma chancela estatal que autoriza a utilização oficial do nome social" ${ }^{56}$. Para o magistrado, o que se nomeia por "transexualidade" seria "[...] o transtorno de identidade de gênero, ou seja, a mulher que nasceu num corpo de homem e o homem que nasceu num corpo de mulher". Crê o julgador ser fundamental a existência de um laudo que ateste a patologia para "evitar questionamento em juízo." ${ }^{57}$ Asseverou que fez algumas audiências apenas quando não absolutamente seguro do "transexualismo" da demandante, porém a maior parte das decisões é dada sem que tenha contato pessoal com as partes, por isso a importância do laudo assinado por "especialistas". Disse-me ainda que precisa acreditar nos argumentos do laudo e no acompanhamento psicológico porque visivelmente não saberia diferenciar "um travesti de um transexual!" e travestis não deveriam mudar o prenome porque podem se arrepender da mudança. Repetindo algumas vezes que se apoia integramente no laudo e ou no acompanhamento psicológico para se assegurar que está diante de um "indivíduo transexual verdadeiro", alertou-me que o parecer do Ministério Público é mais importante que a decisão em si, em razão do estudo apurado realizado naquele, fazendo com que decida quase sempre acompanhando os argumentos do promotor de justiça. Questionei-Ihe sobre a necessidade de uma legislação que regulamentasse o tema. Respondeu-me que tem "dúvidas quanto à necessidade de lei específica para tanto", pois o problema não pode ser ignorado e "[...] mesmo na ausência de lei regulamentando a matéria o Poder Judiciário já vem deferindo a alteração do prenome de transexuais em obediência ao princípio da dignidade da pessoa." Assim, para solucionar a demanda, o magistrado pontua que

\footnotetext{
${ }^{56}$ Nome social é expressão cunhada no movimento LGBTTT para se referir ao prenome adotado por travestis, transgêneros e transexuais. Há hoje no âmbito do Poder Executivo brasileiro resoluções como as do Ministério da Saúde e da Educação, bem como algumas Secretarias Estaduais de Educação, que obriga os órgãos subordinados a tratarem as sujeitas e os sujeitos com os seus nomes sociais. O magistrado destaca, além do cartão do SUS, o tratamento livre de discriminação, com a possibilidade de escolha do nome social nas provas do ENEM ocorridas pela primeira vez nas edições do ano de 2014.

Ver em:

http://g1.globo.com/educacao/enem/2014/noticia/2014/05/transexual-podera-usar-nome-social-noenem-veja-dicas-sobre-inscricao.html

Último acesso em 01/03/15.

${ }^{57}$ Eis o trecho da entrevista destacada na integra: "É fundamental a existência de um laudo que ateste a transexualidade. Mesmo que a Organização Mundial de Saúde deixe de classificá-la no CID Código Internacional de Doenças, em atenção a um movimento mundial que visa desconsiderar a transexualidade como doença, entendo fundamental a palavra de um profissional que ateste a transexualidade até mesmo para evitar questionamento em juízo".
} 
"se todos nós usássemos um pouco de bom senso, seria desnecessária a existência de qualquer lei para regulamentar essa questão." Interpretei esse trecho do discurso como uma tentativa de escuta da demanda real da sujeita, embora se refira àquelas como "ele", "o indivíduo", "o requerente" mostrando certa desconexão entre a escuta e a resposta. Por fim, falou da filha do jogador Toninho Cerezo que se arrependeu da cirurgia ${ }^{58}$ justificando o cuidado que se deve ter com "quem faz as cirurgias".

Alguns anos antes, em 2012, na sentença de alteração de prenome de Malévola, o mesmo julgador, se convencendo dos argumentos dos advogados e do parecer ministerial, resolveu a lide:

Dada a palavra ao Ministério Público assim se manifestou: "Embora - requerente ainda não tenha sido submetido a cirurgia de redesignação sexual nota-se pelo laudo psicológico apresentado tratar-se de transexualismo. Pela prova oral, restou provado que 0 requerente é conhecido pelo prenome de XXXX. Segundo a jurisprudência a demonstração de que as características físicas e psíquicas do indivíduo se apresenta como mulher, não estão em conformidade com as características e seu nome masculino representa coletiva e individualmente, são suficientes para determinar a sua alteração. Assim sendo, com fundamento nos artigos 55, parágrafo único e 58 da LRP oficia pelo deferimento da alteração do prenome". Após, pelo MM. Juiz foi proferida a seguinte sentença: "Diante das provas constantes dos autos, bem como da análise visual do requerente, comprovou-se objetivamente que este possui aparência física e comportamento de pessoa do sexo feminino, não se adequando, assim, ao seu nome de registro, $X X X X X X$. Diante de tal fato é notório que o requerente passa por constrangimentos ao ter que se identificar com um nome masculino, passando por transtornos de ordem psíquica, tal como ficou corroborado pela declaração de seu irmão e depoimento pessoal de seu psicólogo. Assim, tal situação fática, suficientemente comprovada, é bastante para justificar a alteração de prenome do requerente. [...] (Grifos não originais)

Note-se que a sentença reforça os argumentos do magistrado quanto à necessidade de laudo psicológico embasado em "transexualismo". Com os depoimentos das testemunhas o julgador constatou que a requerente era conhecida

\footnotetext{
${ }^{58}$ Lea T, modelo internacional, filha do ex-jogador de futebol. Em entrevista ao Fantástico em 27/01/2013 ela falou do "arrependimento" da cirurgia. Ver matéria em:

http://g1.globo.com/fantastico/noticia/2013/01/cirurgia-nao-trouxe-felicidade-diz-lea-t-apos-troca-de-

sexo.html

Entretanto, alguns meses depois, a modelo deu outra entrevista e contextualizou melhor aquele momento, dizendo "Em nenhum momento falei que me arrependi. Só entendi que fazer isso não era fundamental." Ver em:

http://www.istoe.com.br/reportagens/281579 NAO+ME+ARREPENDI+DA+CIRURGIA+SO+NAO+ER A+FUNDAMENTAL+

Último acesso em: 01/03/15.
} 
nos meios sociais pelo prenome que utilizava que não coincidia com aquele que lhe atribuíram ao nascer.

Abaixo o trecho da inicial da ação de alteração de prenome de Malévola, com os termos usados por ela para se referir a si mesma e mantidos pelos advogados:

\begin{abstract}
A REQUERENTE pretende alterar sua documentação, adequando-a a realidade vivenciada, qual seja: a de ser uma mulher, conhecida como XXXXX. A mesma foi registrada com nome e sexo masculinos, pelo fato de ter nascido com o órgão genital masculino, entretanto, esta nunca se enxergou como pertencendo a este gênero, o que fez inevitavelmente que passasse a se autodeterminar como mulher em todos os aspectos de sua vida. Sempre se viu como mulher. O sentimento feminino sempre esteve presente em sua vida. Lembra que com cinco anos de idade já se sentia uma mulher, independente do estereótipo. Sentia-se menina quando brincava de boneca ou jogando bola, usando vestido ou shorts. [...]

Apesar de se reconhecer e ser conhecida por todos de seu convívio como XXXXX, a mesma, ainda hoje, passa por problemas em relação ao seu nome, pois sempre que tem a necessidade de apresentar seus documentos de identificação, se sente constrangida, pois sabe que, na realidade, a manutenção até este momento do nome constante em seus registros é fruto de uma eventualidade e ignorância social, que reflete na sua vida e na de várias outras pessoas. (Grifos não originais).
\end{abstract}

Malévola afirma que é mulher, se sente mulher, vive o gênero feminino e o que sustenta a manutenção do nome do gênero masculino atribuído a ela ao nascer é a ignorância social acerca da ênfase a um dado da natureza (nascer com pênis, escrotos), desconsiderando a fala da sujeita sobre $\mathrm{si}^{59}$.

\title{
O Ministério Público.
}

Quanto à atuação do Ministério Público, fazem-se necessárias algumas considerações sobre a obrigatoriedade da presença do Parket em processos dessa natureza. No artigo 127 da Constituição Federal de $1988^{60}$ há o dispositivo legal

\footnotetext{
${ }^{59}$ Nas cenas de vida de Malévola ela explana mais sobre a excessiva ênfase nos genitais para se definir uma sujeita.

${ }^{60}$ Art. 127. "O Ministério Público é instituição permanente, essencial à função jurisdicional do Estado, incumbindo-lhe a defesa da ordem jurídica, do regime democrático e dos interesses sociais e individuais indisponíveis". Disponível em:

http://www.planalto.gov.br/ccivil_03/constituicao/constituicaocompilado.htm
} 
apresentando o MP como entidade cuja legitimidade de atuação está fundamentada no interesse público. Em diversos ramos do direito há a previsão de atuação do MP, cada um com sua singularidade e condições. Porém, interessa a esse trabalho apenas o acompanhamento dos processos como definido pelo Código de Processo Civil: "nas causas concernentes ao estado da pessoa [...]", ${ }^{61}$ em que o MP oficiará como fiscal da lei ou custus legis. A Lei de Registros Públicos (Lei no 6.015/73) prevê no artigo 57 a participação do órgão ministerial nas ações em que se busque a alteração posterior de nome "somente por exceção e motivadamente"62. Por isso, o parecer do MP é peça essencial nos autos, sob pena de nulidade ${ }^{63}$. Vale lembrar que a alteração de prenome no ordenamento brasileiro se configura como espécie de "jurisdição voluntária ${ }^{64 "}$, ou em outras palavras, por única e exclusiva vontade da autora da ação. Apesar de ser um processo judicial, faltam-lhe diversas características, tais como: a parte contrária, o litígio, a pretensão resistida, etc. O MP atua nessas situações como instância fiscalizadora para a proteção dos interesses de toda a sociedade.

$\mathrm{Na}$ entrevista ocorrida em 19/11/14, cujas perguntas foram previamente enviadas e respondidas por e-mail ${ }^{65}$ para 0 promotor de justiça que oficia na $2^{\text {a }}$ Promotoria de Registros Públicos do MPDFT, podemos compreender melhor a precedência dos argumentos formais, ou jurídico-instrumentais, em detrimentos dos fatos ou singularidades da vida das sujeitas. Perguntei-Ihe primeiramente se saberia quantificar o número aproximado de ações de alteração de prenome em pessoas que não se identificavam com o sexo de nascimento em que teria atuado.

Último acesso em: 03/02/15.

61 “Art. 82. Compete ao Ministério Público intervir: [...] II - nas causas concernentes ao estado da pessoa, pátrio poder, tutela, curatela, interdição, casamento, declaração de ausência e disposições de última vontade;"

62“Art. 57. A alteração posterior de nome, somente por exceção e motivadamente, após audiência do Ministério Público, será permitida por sentença do juiz a que estiver sujeito o registro, arquivando-se o mandado e publicando-se a alteração pela imprensa, ressalvada a hipótese do art. 110 desta Lei."

63 "Art. 84. Quando a lei considerar obrigatória a intervenção do Ministério Público, a parte promoverIhe-á a intimação sob pena de nulidade do processo."

${ }^{64}$ Mais a frente conceitualizaremos melhor esse termo.

${ }^{65}$ Após identificar promotores que atuavam nas varas de registros públicos, visitei o gabinete de dois deles. Ambos alegaram que não tinham tempo para entrevistas pessoais, mas que poderíamos enviar as perguntas por e-mail que prontamente seriam respondidas. Apenas um deles respondeu aos questionamentos alguns dias depois. Do outro nunca recebemos a resposta. 
Respondeu-me que deve ter oficiado em mais ou menos cerca de quinze casos entre os anos de 2013 a 2014, ressalvando que são três as promotorias de registros públicos e que essa quantidade se refere exclusivamente à promotoria em que é o titular. O promotor atua naquela promotoria desde 2005 e na visão dele a razão que leva essas sujeitas a demandarem a alteração é "[...] o desejo de poder se identificar formalmente com o prenome por ela escolhido (já utilizado socialmente) e que, no seu entender, melhor se adequa à sua condição de sexo ou gênero". Sobre o que se chama de transexualidade, o promotor acredita que seja uma "condição", quando uma pessoa se identifica pertencente ao sexo oposto, que em muitas vezes traz "o desejo de submeter-se a cirurgia de redesignação sexual". Inquiri ao promotor se acredita ser importante um laudo "atestando ser a pessoa transexual". Respondeume que não é imprescindível para o julgamento, mas se a pessoa anexa "um laudo que ateste essa condição, poderá ter seu pleito prontamente atendido, sem a necessidade de realização de audiência para oitiva de testemunhas ou produção de outras provas". Diante da importância do laudo no papel central ou de "rainha das provas"66 nessas questões, perguntei-Ihe se acreditava que o desejo expresso de determinada sujeita em alterar o prenome, por ser socialmente conhecida por nome do sexo/gênero em descompasso com o assento civil não seja razão por si só suficiente para a autorizar a mudança, sem a necessidade de laudos. O promotor me respondeu que sim, porém que nesse caso, será necessária a produção de prova oral em audiência com o encargo de provar totalmente por conta da sujeita. Perguntei-Ihe o que de fato essas pessoas desejariam com uma ação como esta. Disse-me que não teria condições de responder essa questão, mas que na atuação como promotor na área de registros públicos "identificar esse desejo não tem maior relevância na análise de pedidos de alteração de prenome". Essa resposta, embora não seja reveladora para essa dissertação, melhor expressa o que importa ou não aos atores jurídicos, de maneira geral, num processo judicial. A linguagem de "redução a termo" define e delimita determinada lide processual. Significa dizer que os operadores trabalharão com as questões jurídicas (ou fáticas com relevância jurídicas) que importem numa solução jurisdicional. Os fatos havidos (e aqui os

\footnotetext{
${ }^{66}$ Alguns juristas chamam a prova pericial de "rainha das provas." Para outros, esse termo se acomodaria melhor à confissão da parte contrária. De todo modo, seu caráter de "nobreza", se houver, só se aplica aos ramos do direito penal ou do trabalho. No processo civil não há escalonamento entre as provas em razão do princípio do livre convencimento motivado, artigo 131 do Código de Processo Civil. A expressão "rainha das provas" aqui utilizada é um estranhamento à excessiva ênfase dada ao laudo, fazendo com que ele seja elemento suficiente ao pleito.
} 
desejos de sentir-se ou identificar-se como mulher ou como "transexual") não são mais relevantes - nas palavras do promotor - para a análise dos pedidos no âmbito de atuação dos Registros Públicos porque a demanda de alteração de prenome não adentra essas questões de identidade e pertencimento, mas tão somente a autorização ou chancela para se utilizar civilmente nome pelo qual é conhecida, que não conste do assento civil e que seja do sexo ou gênero oposto. Por fim, questionei se na opinião do promotor seria importante uma legislação que regulamentasse a matéria. Respondeu-me que não, pois a "legislação existente (Lei de Registros Públicos), aplicada em conformidade com os princípios constitucionais (em especial o da dignidade da pessoa humana) é suficiente".

Nas entrevistas acima, os operadores do direito opinam pela desnecessidade de uma legislação específica. Ambos, em alguma medida, enfatizam a importância do laudo "atestando ser a pessoa transexual" para facilitar o deferimento. A precedência do laudo e certa irrelevância da fala da sujeita sobre si marcam a inteligibilidade da lide no aporte "transexual" e não na identidade da requerente, seja pela economia processual na visão da "redução a termo" (e dos filtros judiciais), seja na possibilidade da fundamentação da decisão do pleito na categoria "transexual", pois a identidade de mulher ou do sexo feminino, por si só, não autorizaria a mudança documental. Afinal ser mulher não depende de autorização judicial.

\subsection{A atuação moral do Poder Judiciário.}

Uma magistrada que não quis ser entrevistada ${ }^{67}$ proferiu sentença nos autos de substituição de gênero. Inicialmente, a juíza parece compreender o pedido sob o ponto de vista da autora. Entretanto, a partir da metade da decisão, a julgadora lança mão de um termo ("indivíduo transexual") sequer mencionado na

\footnotetext{
${ }^{67}$ Selecionamos a juíza em razão de ela ter deferido o pedido de alteração de gênero de uma sujeita requerente. No primeiro contato, a assessoria da magistrada afirmou ser possível a entrevista. Entretanto, tão logo a magistrada soube que eu havia atuado como advogada no processo, denegou o pedido de entrevista alegando que não seria ético. Redargui, dizendo que o processo já estava arquivado, que não haveria nenhum impedimento ético e que a própria sujeita havia me dado autorização para utilizar a decisão sem especificar a parte. Além do mais, informei à juíza que a entrevista não seria sobre aquele processo em particular, mas apenas sobre o conjunto legalprocessual que envolve essas ações. Contudo, ela não respondeu mais aos meus contatos.
} 
inicial e desenvolve os argumentos até o desfecho sob essa ótica. Tivemos acesso à decisão ${ }^{68}$, cujo trecho transcreve-se abaixo:

[...] Pretende a parte autora a retificação de seu assentamento civil para que nele conste que é do sexo feminino. Ressaltou nos autos que apresenta características femininas desde tenra idade e a realização da cirurgia de genitoplastia ${ }^{69}$, também conhecida como "mudança de sexo", apenas viabilizou a adequação ao sexo feminino, que entendia e sentia já pertencer [...] impor a parte autora manutenção obrigatória de seu estado sexual em razão exclusivamente de seu aspecto físico de nascimento seria desconsiderar as demais questões que envolvem a psique e a sexualidade do ser humano, contrariando, como dito em linhas volvidas, os fundamentos em que se baseia o Estado brasileiro, que abriga explicitamente em seu artigo $1^{\circ}$, inciso III, da Constituição Federal de 1988, a proteção à dignidade da pessoa humana. Além disso, importante ressaltar que a jurisprudência brasileira admite a retificação do registro civil de transexual, a fim de adaptar o assento de nascimento à situação decorrente de realização de cirurgia para mudança de sexo (STJ: SE 1.058/EX; REsp 678.933/RS; REsp 1008398/SP, dentre outros). Assim, impõe-se o deferimento do pedido relativo à mudança de sexo da parte autora (indivíduo transexual) que representa a última etapa para a sua completa adequação à condição do sexo feminino. Não acolher o pedido formulado na exordial simplesmente significa postergar o exercício do direito à identidade pessoal e subtrair do indivíduo a prerrogativa de adequar o registro do sexo de sua nova condição física, além de impedir a sua plena integração na sociedade. [...] Contudo, não é possível acolher o pedido para que não conste na certidão de nascimento da parte autora anotação de que a retificação do sexo se deu em virtude de decisão judicial. A questão já foi debatida e definida pelo Superior Tribunal de Justiça - STJ, firmando-se no sentido de que é necessária a correlação entre o teor do registro e a realidade/veracidade fática, pois "não se pode esconder no registro, sob pena de validarmos agressão à verdade que ele deve preservar, que a mudança decorreu de ato judicial, nascida da vontade do autor e que tornou necessário ato cirúrgico complexo. Trata-se de registro imperativo e com essa qualidade é que se não pode impedir que a modificação da natureza sexual fique assentada para o reconhecimento do direito do autor.", conforme destacado pelo Ministro Carlos Alberto Menezes de Direito, no REsp 678.933/RS, cuja ementa transcrevo a seguir [...]. Dessa forma, forçoso acolher a manifestação do Ministério Público e deferir, em parte, os pedidos constantes da inicial [...] Ante o exposto, julgo parcialmente procedentes os pedidos contidos na inicial, para autorizar: a) a alteração do sexo de xxxxxx indicado no registro civil -

\footnotetext{
${ }^{68}$ Atuei como advogada da parte requerente nesse processo. Embora a sujeita não se importasse em descrever a decisão desde que mantivéssemos o sigilo total, não desejou fazer parte do Panteão de Interlocutoras-Bruxas dessa dissertação.

${ }^{69}$ Não encontrei esse termo na literatura médica especificadamente para as alterações genitais nesses casos. O termo genitoplastia no geral se refere a meninas e meninos cuja genitália parece ambígua aos olhos da medicina, necessitando-se de uma definição sexual/genital, seja na formação de uma vagina (ou neovagina), seja num pênis. O mesmo que intersexual ou hermafrodita.
} 
de "masculino" para "feminino", restando mantidas as demais anotações no seu registro de nascimento; e, b) a averbação, apenas no livro cartorário e à margem do sexo que consta no registro civil, de que a alteração é oriunda de decisão judicial; vedada qualquer menção nas certidões do registro público, sob pena de manter a situação constrangedora e discriminatória. (grifos originais).

A sentença se distancia dos argumentos trazidos na peça vestibular da requerente. Em nenhum momento a sujeita se identifica ou nomeia-se como "transexual" na petição inicial:

[...] A razão do pleito se dá porque a Requerente é mulher e se sente assim desde a infância, tendo sido coerente com sua identidade por toda a vida. Ocorre que nasceu com a genitália considerada masculina, entretanto sempre se SOUBE mulher, pertencente ao gênero feminino. Atualmente, os documentos civis da Requerente continuam grafados com o gênero masculino o que causa inúmeros constrangimentos, pois além do nome ser feminino, hoje o corpo também o é, e a manutenção do gênero no assento civil como "masculino" além de não corresponder à realidade dos fatos, instiga malícia e curiosidade vã. Podemos entender, inclusive, que o prolongamento dessa situação ocasiona violações aos DIREITOS DE PERSONALIDADE da autora. Um exemplo disso é a situação de afronta à sua intimidade quando tem de mostrar seu passaporte, pois lá está grafado que se trata de uma pessoa chamada XXXXXXXXXX, mas seu gênero é "masculino" (em anexo). Para evitar passar por tais situações, a Requerente evita viajar ao Exterior, já que além das autoridades brasileiras, autoridades de outros países, podem barrarIhe a entrada em razão da informação em descompasso com seu ser [...] (Grifos não originais).

A conclusão do caso estudado é de que a sujeita afirmou-se de uma forma e a "escuta" da magistrada foi em outro sentido, numa espécie de "jogo do surdo", cujo resultado da sucessão de argumentos não é um encadeamento lógico dos debates com o êxito em determinada tese, mas o ponto final se dá com afirmação terminativa do juiz que deve ser acatada porque detém autoridade, a última palavra; e a sujeita está dependente de um desfecho positivo, mesmo que signifique insulto moral ou diminuição da sua identidade. Como se verá nos capítulos etnográficos há significativa parcela do pleito das sujeitas que não se limita à alteração de prenome e/ou gênero pura e simplesmente. Trata-se de pedido mais abrangente: a chancela oficial do reconhecimento da identidade que muitas vezes não se satisfaz com o ganho material de uma decisão. Em outras palavras, as sujeitas não apenas desejam as modificações documentais, mas também o 
reconhecimento de suas identidades. Ao final deste capítulo se debaterá melhor sobre o reconhecimento da identidade.

Voltando a sentença acima, os fundamentos contidos no acórdão mais replicado nesses casos é o n 678.933/RS do Superior Tribunal de Justiça (STJ) prolatado em 2007, de autoria do falecido ministro Carlos Alberto Menezes Direito, cuja ementa ou resumo do discutido, se repete abaixo (litteris):

\section{EMENTA}

Mudança de sexo. Averbação no registro civil.

1. O recorrido quis seguir o seu destino, e agente de sua vontade livre procurou alterar no seu registro civil a sua opção, cercada do necessário acompanhamento médico e de intervenção que lhe provocou a alteração da natureza gerada. Há uma modificação de fato que se não pode comparar com qualquer outra circunstância que não tenha a mesma origem. O reconhecimento se deu pela necessidade de ferimento do corpo, a tanto, como se sabe, equivale $o$ ato cirúrgico, para que seu caminho ficasse adequado ao seu pensar e permitisse que seu rumo fosse aquele que seu ato voluntário revelou para o mundo no convívio social. Esconder a vontade de quem a manifestou livremente é que seria preconceito, discriminação, opróbrio, desonra, indignidade com aquele que escolheu o seu caminhar no trânsito fugaz da vida e na permanente luz do espírito.

2. Recurso especial conhecido e provido ${ }^{70}$.(Grifos não originais).

Essa mesma decisão (no jargão jurídico um "precedente jurisprudencial") foi utilizada como argumento para o deferimento da alteração do gênero de Bruxa Malvada do Oeste, mantendo tal averbação no registro civil. Eis o trecho:

[...] Registre-se que a sugestão do Ministério Público, de alterar o nome, mantendo-se, todavia, o sexo masculino, não pode ser aceita. É que a integração na sociedade depende da acomodação do registro, admitindo-se, apenas, a necessidade de averbação à margem do registro, que a alteração do nome e sexo é oriunda de decisão judicial, ocorrida após cirurgia de transgenitalização, tal como determinou o colendo STJ, pelo REsp no 678.933-RS, Rel. Min, Carlos Alberto Menezes Direito, julgado em 22 de março de 2007, cuja ementa é a seguinte [...]. Ante o exposto, julgo procedente o pedido e determino a retificação do assento de nascimento do requerente, lavrado no Cartório de Registro Civil das Pessoas Naturais da cidade de $x x x x x x$, sob o número $x x x x x x x x x x x x x$, para: 1) substituir o prenome $x x x x x x x x$ por $x x x x x x x x$, passando a se chamar xxxxxxxxx; 2) modificar o sexo masculino para o sexo feminino, permanecendo inalterados os demais dados do assento. Para

\footnotetext{
${ }^{70}$ Disponível em: https://ww2.sti.jus.br/processo/revista/documento/mediado/?componente=ITA\&sequencial=681002\&n um registro $=200400980835 \&$ data $=20070521$ \&formato=PDF

Último acesso em: 01/03/15.
} 
resguardar interesses de terceiros, determino que seja averbada, à margem do registro, que a alteração de nome e sexo é oriunda de decisão judicial, ocorrida após cirurgia de transgenitalização. Transitada em julgado, expeça-se o mandado de averbação. (grifos não originais).

Para o Judiciário há um conflito se não atual, ao menos potencial, entre os interesses jurídicos da sujeita que altera o prenome e/ou o gênero e eventuais terceiros que venham a realizar negócios jurídicos com aquela. Um exemplo comum é do homem que deseje se casar com uma mulher que nasceu com pênis, realizou a cirurgia, alterou o prenome e o gênero nos documentos civis, sem que o futuro marido saiba dessa trajetória. Em comum com mulheres inférteis, essa mulher não poderá gerar filhos. Deve então o Estado-Juiz manter grafado no seu registro civil tais questões? Foi nesse sentido a preocupação quando da decisão do Tribunal de Justiça do Rio Grande do Sul (TJRS) para que figurasse em segredo de justiça no registro civil - sem nenhum acesso a terceiros - as alterações de prenome e gênero havidas, para não expor a sujeita:

Quando se fala em prejuízos a terceiro, na verdade se fala na possibilidade de um homem envolver-se emocionalmente e, por que não dizer, sexualmente com 0 apelado e descobrir, em determinado momento, que ela não poderá ter filhos, ou até mesmo que não é mulher 'de nascimento'. Sendo essa a questão a ser enfrentada, até certo ponto, o mesmo aplicar-se-ia à mulher estéril. Será que deveriam essas mulheres ter em seus documentos e no registro civil contida esta condição? Ou seria uma humilhação para elas? Sofreriam algum tipo de discriminação? E se os seus possíveis companheiros aceitassem essa condição por entenderem ser o amor o bem maior? As respostas são conhecidas. Os casos são assemelhados, e por não ter a mulher estéril que expor sua condição perante a sociedade, não terá P.C ${ }^{71}$. que expor a sua. Cabe ressaltar que essas suposições de eventuais prejuízos que possam sofrer terceiros, são hipóteses, não havendo certeza quanto ao caso concreto. Poderia acontecer ou não. Por isso, não seria plausível a exposição da condição de transexual feminino do recorrido em virtude de projeções, e, como tais, aleatórias. Se houver, no futuro, alguém que se sinta ameaçado, ou até mesmo prejudicado moralmente em razão da alteração de vida pela qual optou o apelado, que procure o remédio jurídico cabível. 0 Direito não pode ficar atrelado ao que dispõem as normas vigentes no país. O Direito é realidade, é fato social. É o excepcional. Deve, portanto, o Direito, não fechar os olhos à realidade, e se inserir nos tempos modernos, evitando qualquer situação constrangedora para as partes que litigam perante a justiça, contribuindo sempre para a paz social (trecho contido no relato dos atos processuais do REsp no 678.933/RS. Grifos não originais).

\footnotetext{
71 "PC" são as iniciais do nome da sujeita requerente protegida pelo sigilo legal no próprio tribunal.
} 
Essa decisão foi um dos argumentos jocosamente depreciado nos debates ocorridos no STJ. Embora juridicamente ponderada, não foi essa a linha decisória adotada pelo Tribunal da Cidadania. $\mathrm{O}$ argumento vencedor foi aquele de cunho moral, pretensamente altruísta e de natureza religiosa, como se verá mais a frente.

Assim, em consonância com os julgados atuais, o conflito de interesses tem sido resolvido em favor "dos terceiros" - potenciais e hipotéticos - em detrimento da dignidade das sujeitas, pois na prática terá ela necessariamente averbado no registro originário, á margem do item sexo, a expressão: "[...] a alteração é oriunda de decisão judicial", sem que tenha sido esse o pedido. Na verdade a sujeita deseja que se "esqueça", que se "apague" social e registralmente o fato pretérito, como se verá abaixo e, mais detalhadamente, nas cenas de vida.

\subsection{Direito ao esquecimento.}

No chamado "direito ao esquecimento", ocorrido, sobretudo nos registros de menores adotados ${ }^{72}$, a situação da adoção por nova família traz como consequência jurídica a anulação do registro civil originário, criando-se outro inteiramente novo e, a partir desse, as alterações civis importantes da vida da pessoa (nascimento, casamento, separação, ausência, morte) são averbadas. Em razão de algumas das falas, pode-se afirmar que a vontade das sujeitas nos pedidos das ações de retificação de prenome ou gênero é a de que não se conste nada da alteração havida, como se a sujeita houvesse nascido no gênero feminino, como consta na peça inicial de alteração de gênero:

[...] que seja decretada a retificação de registro de nascimento da Requerente, determinando-se a troca do gênero desta para "feminino", sem quaisquer menções na certidão de nascimento,

\footnotetext{
${ }^{72}$ Artigo 47 do Estatuto da Criança e do Adolescente (ECA), Lei 8.069/90: "O vínculo da adoção constitui-se por sentença judicial, que será inscrita no registro civil mediante mandado do qual não se fornecerá certidão". Os parágrafos deste artigo complementam: "§ $2^{\circ} \mathrm{O}$ mandado judicial, que será arquivado, cancelará o registro original do adotado" e "§ $4^{\circ}$ Nenhuma observação sobre a origem do ato poderá constar nas certidões do registro".
} 
expedindo-se o competente mandado para o Cartório de Registro Civil. (Grifos não originais).

E em outro pedido de um caso do Rio de Janeiro/RJ:

[...] Sendo assim, requer o recorrente a alteração do sexo no registro civil para que passe a constar o sexo feminino, sem nenhuma referência, no assentamento, às alterações sofridas ${ }^{73}$. (Grifos não originais).

Voltando às decisões cuja averbação conste no registro civil, as consequências jurídicas da declaração é que pela Lei de Registros Públicos, em tese, eventual interessado ${ }^{74}$ poderá requerer cópia do livro para buscar a "mulher fraude"75. Assim, a mudança física, real, tangível é mesclada a uma simulação de mudança jurídica. Para preservar os registros públicos - os potenciais e hipotéticos direitos de terceiros - desconsidera-se a sujeita.

Lembrando que os atos obrigatórios de registros civis das pessoas naturais se dividem em "registráveis" (a exemplo daqueles referidos no artigo 9ํำ do Código Civil de 2002 e do artigo $29^{76}$ da Lei de Registros Públicos) e "averbáveis" (os atos civis que devem constar à margem do registro original sempre que houver quaisquer alterações posteriores. Como exemplo, o artigo 10 do Código Civil de

\footnotetext{
${ }^{73}$ Trecho fático extraído do inteiro teor da decisão monocrática do Ministro João Otávio de Noronha no REsp no 876.672/RJ, do dia 1ํ de março de 2010, p. 2. Ver em: https://ww2.sti.jus.br/processo/revista/documento/mediado/?componente=MON\&sequencial=7102907 \&num registro $=200601752260$ \&data $=20100305 \&$ formato=PDF Último acesso em: 19/11/14.
}

${ }^{74}$ Segundo informações do Cartório de Registros Civis de Brasília/DF, o interessado deverá entrar com uma ação cabível, justificando o motivo do interesse. O juiz poderá ou não consentir que ele tenha acesso ao livro registral. O parágrafo $2^{-}$do artigo $6^{\circ}$ da Lei 8.560/1992 (investigação de paternidade dos filhos nascidos fora do casamento) explicita um exemplo desse procedimento de acesso ao inteiro teor de registro: "São ressalvadas autorizações ou requisições judiciais de certidões de inteiro teor, mediante decisão fundamentada, assegurados os direitos, as garantias e interesses relevantes do registrado".

${ }^{75}$ Maga Patalógica narra a situação de uma sujeita que fora processada pelo marido e "inocentada" da "fraude", posteriormente.

${ }^{76}$ Redação do art. 9ํ do Código Civil de 2002 (Lei 10.406/2002) "Serão registrados em registro público: I - os nascimentos, casamentos e óbitos; II - a emancipação por outorga dos pais ou por sentença do juiz; III - a interdição por incapacidade absoluta ou relativa; IV - a sentença declaratória de ausência e de morte presumida". Art. 29 da Lei de Registros Públicos: "Serão registrados no registro civil de pessoas naturais: I - os nascimentos; II - os casamentos; III - os óbitos; IV - as emancipações; V - as interdições; VI - as sentenças declaratórias de ausência; VII - as opções de nacionalidade; VIII - as sentenças que deferirem a legitimação adotiva". Todos esses casos devem constar dos registros nos respectivos livros. 
$2002^{77}$ e o parágrafo primeiro do artigo 29 da LRP, esse último uma repetição do que consta naquele Código). As averbações são obrigatoriamente mencionadas nas certidões do registro como "observações" ou ainda comunicadas (igualmente como "observações") que no registro originário "a presente certidão envolve elementos de averbação à margem do termo ${ }^{78}$ ", sob pena de responsabilidade civil e criminal pela omissão, com exceção do reconhecimento de paternidade e da adoção.

Outro argumento frequentemente adotado para manter averbações em registros civis de sujeitas submetidas à adequação genital (na linha da preservação dos registros públicos e dos eventuais direitos de terceiros que se sentirem prejudicados) é o chamado "erro essencial sobre a pessoa" potencialmente presente nas situações de casamentos, onde o futuro cônjuge da sujeita não sabe das alterações. Entretanto, não é apenas a adequação cirúrgica genital que pode provocar debates na esfera judicial, mas diversos outros "ocultamentos", tais como: "honra"; "boa fama"; cometimento de "crime anterior ao casamento"; "defeito físico" ou "doença mental" ${ }^{\text {, }}$ entre outras categorias que ensejam a declaração judicial do erro essencial.

Evidentemente que no Brasil, um país em que os meios legítimos convivem pacificamente com os ilegítimos (antiéticos, e mesmo ilícitos), não será

\footnotetext{
${ }^{77}$ Art. 10: "Far-se-á averbação em registro público: I - das sentenças que decretarem a nulidade ou anulação do casamento, o divórcio, a separação judicial e o restabelecimento da sociedade conjugal; II - dos atos judiciais ou extrajudiciais que declararem ou reconhecerem a filiação."

${ }^{78}$ Diz o art. 21 da LRP: "Sempre que houver qualquer alteração posterior ao ato cuja certidão é pedida, deve o Oficial mencioná-la, obrigatoriamente, não obstante as especificações do pedido, sob pena de responsabilidade civil e penal, ressalvado o disposto nos artigos 45 e 95 . Parágrafo único. A alteração a que se refere este artigo deverá ser anotada na própria certidão, contendo a inscrição de que "a presente certidão envolve elementos de averbação à margem do termo"'.

${ }^{79}$ Ver: art. 1556 do Código Civil de 2002. "O casamento pode ser anulado (no prazo de três anos a contar da data da celebração) por vício da vontade, se houve por parte de um dos nubentes, ao consentir, erro essencial quanto à pessoa do outro".

${ }^{80}$ Ver: art. 1.557 do Código Civil de 2002. "Considera-se erro essencial sobre a pessoa do outro cônjuge: I - o que diz respeito à sua identidade, sua honra e boa fama, sendo esse erro tal que o seu conhecimento ulterior torne insuportável a vida em comum ao cônjuge enganado; II - a ignorância de crime, anterior ao casamento, que, por sua natureza, torne insuportável a vida conjugal; III - a ignorância, anterior ao casamento, de defeito físico irremediável, ou de moléstia grave e transmissível, pelo contágio ou herança, capaz de pôr em risco a saúde do outro cônjuge ou de sua descendência; IV - a ignorância, anterior ao casamento, de doença mental grave que, por sua natureza, torne insuportável a vida em comum ao cônjuge enganado".
} 
difícil a quem conhecer os meios ter acesso a um registro. Em verdade, para os servidores que trabalham em varas ou promotorias de família o acesso é franqueado, sem quaisquer restrições. Para o curioso que burlar o sistema, diante da confirmação registral de uma "farsa", a sujeita volta a ser objeto da curiosidade e maldade de quem jamais a verá como ela, mas sempre como "ele", "o transexual" 81 .

Em conversa com um defensor público que trabalhou em casos de alteração de prenome junto à Vara de Registros Públicos de Brasília/DF ${ }^{82}$, relatoume que as questões jurídicas das ações de alteração de prenome não versam sobre o "estado da pessoa" ${ }^{83}$, por isso o entendimento da justiça do Distrito Federal é de que devam ser processadas e julgadas nas varas de registros públicos; enquanto as ações de substituição ou reconhecimento do gênero são julgadas nas varas de família. Explicou-me também que a alteração do prenome não está normatizada por instrumento legal, mas na concepção dele segue uma "brecha frágil" da Lei de Registros Públicos. Foi o uso reiterado pelos operadores do direito que legitimou o entendimento da doutrina e da jurisprudência. Embora pela via do estado da pessoa e do processamento das demandas pelas varas de registros públicos propiciem um meio mais simples e célere de resolução ${ }^{84}$, o defensor público é particularmente contra essa medida, pois se trataria de direito de família "dada à complexidade da causa". Para fundamentar melhor essa opinião, cita o caso de uma requerente que

\footnotetext{
${ }^{81}$ A narrativa de Malévola explicita melhor esse tema, seus desejos, medos e dilemas.

${ }^{82}$ Estivemos em um dos postos da Defensoria Pública do Distrito Federal e informamos sobre a pesquisa. Um defensor público mostrou interesse em conversar naquele momento. Interessante notar que embora não tenhamos marcado dia e hora previamente para a entrevista, esse foi o único operador do direito com tempo e disposição em ser entrevistado, inclusive imediatamente.
}

${ }^{83}$ No sítio de educação jurídica online "Jurisway", encontra-se uma definição bem simples sobre estado da pessoa: "O estado pode se distinguir em: estado civil, em que a pessoa pode ser classificada como casada, solteira, divorciada, ou viúva; estado político, que diferencia as pessoas pelo fato de serem nacionais, ou estrangeiros, e estado individual, que distingue os sexos feminino e masculino, ou se refere ao fato da pessoa ser maior ou menor de idade". No mesmo texto o autor adverte que todas essas situações se provam pelos registros públicos. Ver em: http://www.jurisway.org.br/v2/pergunta.asp?idmodelo $=6408$

Último acesso em: 19/11/14.

${ }^{84}$ Pelo rito da daquela lei, as ações que se aproximam de um "procedimento administrativo" de jurisdição voluntária (ou seja, pela vontade livre da requerente), dão-se logo no início do processo. A demandante solicita ao Poder Judiciário que reconheça sua situação fática e que declare a alteração na documentação civil. Entretanto, por aquele rito só se pode alterar o prenome civil, nunca o gênero do registro, pois para a averiguação dessa última qualidade da indivídua se demandaria um processo formal, de natureza ordinária e com toda a complexidade que pode envolver (audiências, testemunhas, perícias, etc). 
realizou as cirurgias e a alteração da documentação após ter sido pai de uma criança. Para ele há interesse dos terceiros envolvidos (os filhos) na modificação da documentação, pois na certidão de nascimento da criança haveria a modificação do nome do genitor, agora, adequado cirurgicamente, mantendo-o como pai, embora com prenome feminino. Vale esclarecer que hoje essa questão foi superada, pois pelos Provimentos nº 2/2009 e nำ 3/2009 do Conselho Nacional de Justiça (CNJ) instituem padrão único na confecção de certidões cartoriais. Assim, por força daquelas normativas as novas certidões de nascimentos não mais designam "nome do pai" ou "nome da mãe", mas tão somente filiação ${ }^{85}$. Ao final do debate, o defensor “apenas por curiosidade" e sem nenhuma cerimônia, violou o segredo de trâmites processuais $^{86}$ para me fornecer o nome completo de uma sujeita que alterou 0 prenome, indicando inclusive onde poderia ser encontrada nas redes sociais, apenas para que eu constatasse o quanto ela é bonita (nas palavras do defensor: "Essa eu fiquei impressionado, linda, linda, linda!"). A prática "sem maldade" do defensor corrobora o que se disse acima que alguém com informações privilegiadas poderá burlar facilmente as regras, tendo acesso e fornecendo informações pessoais e íntimas de outrem a terceiros, se assim quiser.

\subsection{Retrospectiva legal recente.}

Ábiner Mendes Gonçalves, advogado civilista que trabalha há cerca de oito anos com essas ações, faz uma cuidadosa análise nos campos jurídicos sobre as questões da transexualidade ${ }^{87}$, afirmando que a ausência de mecanismos legais

\footnotetext{
${ }^{85}$ Ver em:

http://www.cnj.jus.br///images/atos normativos/provimento/provimento 2270420092610201218080 $\underline{0 . p d f}$

http://www.cnj.jus.br/images/stories/docs corregedoria/provimentos/provimento 03.pdf

Último acesso em: 01/03/15.

${ }^{86}$ Essas causas são processadas em segredo de justiça. Os dados pessoais e o teor de decisões e despachos são sigilosos, só se franqueando acesso aos advogados das partes e as próprias partes. Ver o artigo 155 do CPC. Disponível em:

http://www.jusbrasil.com.br/topicos/10724889/artigo-155-da-lei-n-5869-de-11-de-janeiro-de-1973 Último acesso em: 01/03/15.

${ }^{87}$ Discorre o autor (2012: 102): "Na família e na sociedade é o sexo ou gênero que acaba por determinar e revelar os interesses e as necessidades do ser humano, quais sejam, a de viver de forma que corresponda àquilo a que sinta pertencer. $E$ aí está a base do problema da transexualidade. Trata-se em um drama jurídico-social, que se acusa quando ocorre a cisão entre a
} 
legítimos tanto para regulamentação da cirurgia, quanto para a alteração de prenome (e gênero), promovem a negativa de direitos. Nesse sentido (: 103):

É necessário preencher essa lacuna para se oportunizar direitos negados a esta parcela da população, permitindo um acesso mais fácil à saúde, ao mercado de trabalho e à cidadania plena. O que atingirá toda a sociedade de maneira positiva, já que oportunizará debates importantes acerca dos gêneros e suas criações, diferenças e performances.

O advogado, contrariando os três operadores do direito acima (o juiz, o promotor de justiça e o defensor público), alerta que a falta de legislação não torna as alterações efetivas, ao contrário, exatamente pela ausência de regulamentação o Estado não está obrigado a garantir, podendo discricionariamente denegar ou se eximir.

Os artigos 57 e 58 da Lei de Registro Público abordam a alteração de prenome como exceção à regra da imutabilidade do nome, "admitindo-se, todavia, a sua substituição por apelidos públicos notórios" ${ }^{88}$, porém, a limitação da legislação não contempla a modificação do prenome e sexo ou gênero, embasado ou não na cirurgia de adequação genital. A omissão prossegue no Código Civil $2002^{89}$ quanto à alteração de prenome e gênero e ainda em relação ao registro das sentenças, contendo inclusive a proibição expressa da disposição sobre o próprio corpo, salvo por exigência médica90, "sem maiores aprofundamentos o Código Civil acaba deixando para a Lei de Registros Públicos disciplinar sobre o nome e o estado da pessoa, no registro de nascimento". (: 40-41).

Mendes Gonçalves analisa também as últimas tentativas legislativas brasileiras do que se nomeia como transexualidade ${ }^{91}$. Desde a década de 1970, a

personalidade jurídica; a identidade sexual física, ditada pelo nascimento; e a real personalidade, identidade psíquica, que só com o tempo se firma com nitidez."

${ }^{88}$ Caput do artigo 58, Lei de Registros Públicos.

${ }^{89} \mathrm{O}$ autor traz os artigos 9ำ e 10 do Código Civil para ilustrar. Já expusemos os conteúdos desses artigos acima.

${ }^{90}$ Diz o artigo 13 do CC/2002: "Salvo por exigência médica, é defeso o ato de disposição do próprio corpo, quando importar diminuição permanente da integridade física, ou contrariar os bons costumes".

${ }^{91}$ Nos textos normativos os termos em geral, são: "transgenitalismo", "transexualismo" e "pessoa transexual". 
maioria delas reconhece as sujeitas e os sujeitos como enfermos, abordando as cirurgias e alterações documentais como "profilaxia" da doença. No PL 70-B de $1995^{92}$, ainda em trâmite na Câmara dos Deputados, a intenção dos legisladores para proteger os eventuais direitos de terceiros é instituir um "terceiro sexo" registral, criando a categoria jurídica de "pessoa transexual":

Art. 58. O prenome será imutável, salvo nos casos previstos neste artigo.

$\S 1^{\circ}$ Quando for evidente o erro gráfico do prenome, admite-se a retificação, bem como a sua mudança mediante sentença do juiz, a requerimento do interessado, no caso do parágrafo único do art. 55, se o oficial não houver impugnado.

$\S 2^{\circ}$ Será admitida a mudança do prenome mediante autorização judicial, nos casos em que o requerente tenha se submetido a intervenção cirúrgica destinada a alterar o sexo originário.

$\S 3^{\circ}$ No caso do parágrafo anterior deverá ser averbado ao registro de nascimento e no respectivo documento de identidade ser pessoa transexual(Grifos não originais).

Para o autor, ao determinar que seja obrigatoriamente grafada no registro de nascimento e no documento de identidade a declaração de "ser pessoa transexual", além de criar uma identidade civil completamente diferente de homem ou mulher, exporá a intimidade da sujeita ou do sujeito:

A pessoa portará documento que será utilizado para discriminações e preconceitos, não possuindo sigilo de sua vida privada, que estará escancarada para qualquer um que queira ver sua certidão de nascimento (instrumento público) e sua carteira de identidade. Tal devassa limitaria acesso ao mercado de trabalho e educação, acarretando reflexos em outros direitos como moradia, atendimento nos serviços de saúde, etc. (: 45).

Demais projetos de lei condicionam as alterações documentais, ora aos procedimentos cirúrgicos (PL 3.727/97) ${ }^{93}$, ora dispensando a sentença judicial após as cirurgias, mediante averbação diretamente no registro civil, no cartório (PL $1.281 / 11)^{94}$. Vale mencionar que pelo sistema jurídico-político atual brasileiro não é possível tal averbação direta no cartório por falta de lei que regulamente. Em outras

\footnotetext{
${ }^{92}$ Disponível em:

http://www.camara.gov.br/proposicoesWeb/prop mostrarintegra;jsessionid=1587D407698BA3BF29B B9E5960546873.node1 ? codteor $=1036327 \&$ filename $=$ Avulso $+-P L+70 / 1995$

Último acesso em: 02/12/14.

${ }^{93}$ Ver em: http://www.camara.gov.br/proposicoesWeb/fichadetramitacao?idProposicao=20118 Último acesso em: 02/12/14.

${ }^{94}$ Ver em: $\underline{\text { http://www.camara.gov.br/proposicoesWeb/fichadetramitacao?idProposicao }=501425}$ Último acesso em: 02/12/14.
} 
palavras, o PL 1.281/11 é juridicamente inconstitucional. Para Mendes Gonçalves, o $\mathrm{PL} \mathrm{n}^{\circ}$ 4.241/12 ${ }^{95}$ é o que mais se atenta às necessidades das sujeitas e dos sujeitos, pois ao tratar do "direito à identidade de gênero" não se utiliza de nomenclaturas ou fundamentações patológicas para reconhecer nos âmbitos jurídicos o que chama de "livre desenvolvimento da identidade de gênero das pessoas" (: 47).

Atualmente, o PL no $5002 / 2013^{96}$ de autoria do deputado federal Jean Wyllys (PSOL) e Érika Kokay (PT) conhecido entre militantes LGBTTT como "Projeto de Lei João Nery - Lei de Identidade de Gênero" ${ }^{97}$ encontra-se em tramitação na Câmara dos Deputados. Nesse PL pretende-se a criação de uma lei específica e ainda a alteração do artigo 58 da Lei de Registros Públicos. Embora semelhante ao PL no 4.241/12 quanto ao reconhecimento da identidade de gênero não atrelada a laudos (Art. 4ํ, §único: “Em nenhum caso serão requisitos para alteração do prenome: [...] III - qualquer outro tipo de tratamento ou diagnóstico psicológico ou médico.") ou mesmo autorização judicial, o PL merece severas críticas, pois se esqueceu de que no Brasil para se alterar o prenome é necessário um processo judicial. Logo, se chegar à lei, está fadado à inconstitucionalidade, porque não se coaduna com o sistema jurídico pátrio. A menos que se modifiquem diversas leis separadamente, inclusive o Código Civil e a Lei de Registros Públicos, ninguém poderá se beneficiar desse PL.

Quanto ao direito comparado, diversos países adotam instrumentos jurídicos que possibilitem as alterações documentais, seja administrativa, seja judicialmente. Em razão de limitações diversas, a presente obra não conseguiria um levantamento substancial de todos. O trabalho de Mendes Gonçalves faz uma breve análise de algumas nações com legislação específica na questão. Inicialmente, o autor adverte que no contexto norte-americano a compreensão dos problemas sobre gênero é diferente da forma como se dá no Brasil. Aquela nação entende as

\footnotetext{
${ }^{95}$ Ver em: http://www.camara.gov.br/proposicoesWeb/fichadetramitacao?idProposicao $=552237$ Último acesso em: 01/03/15.

${ }^{96}$ Ver em: $\underline{\text { http://www.camara.gov.br/proposicoesWeb/fichadetramitacao?idProposicao }=565315}$ Último acesso em: 05/02/15.

${ }^{97}$ Homenagem ao ativista dos direitos de transexuais e "transhomem" (termos daquele) e escritor, João W. Nery que se considera "o primeiro transexual do Brasil". Ver seu blog em: http://jwnescritor.blogspot.com.br/

Último acesso em: 05/02/15.
} 
"múltiplas identificações sexuais" com base nos estudos queer, em que travestis, transformistas, drag queens entre outras identidades fazem parte de "um grande grupo" conhecido simplesmente como "transgêneros" ou "transgender" incluídas ai o que chama de "pessoas que passam pela experiência transexual" (: 69). Em alguns Estados norte-americanos é possível, mediante atestado do médico responsável pela cirurgia ao oficial de registros públicos, para que esse decida sobre a possibilidade da alteração no registro administrativamente. Em outros, a mudança do prenome e o que chama de "status sexual" se dá via processo judicial que lavrará nova certidão de nascimento. Destaque para o Estado da Louisiana que possui a legislação "mais completa e detalhada sobre a matéria" e cuja expedição de nova certidão faz com que a anterior juntamente com o pedido de alteração e a sentença procedente sejam "seladas e arquivadas no ofício de registro civil competente". Ao arquivo só terá acesso a própria pessoa com pedido acompanhando de ordem judicial do mesmo juízo que prolatou a sentença. Caso a pessoa seja casada, deve haver a participação obrigatória do cônjuge em todo o processo, evitando-se assim reclamações posteriores nas questões de família. Nos Estados em que houve a regulação legislativa é garantida nova certidão de nascimento e novos documentos de identificação, omitindo-se informações sobre quaisquer modificações ou motivos, "oportunizando assim um pleno exercício da mudança almejada" (Diniz, 2001; Szaniawski, 1999, apud Mendes Gonçalves: 70-72). O autor conclui o panorama afirmando que "quase todos os Estados dos EUA permitem que o nome e o sexo sejam mudados na certidão de nascimento, seja por meio de alteração da certidão existente ou pela emissão de uma nova". Somente Idaho, Ohio, Tennessee e Texas não alteram o sexo. Esse último é possível via ordem judicial. Entretanto, as casas legislativas e os tribunais de muitos Estados, incluindo o Missouri, não omissos nessas questões. (: 72).

$\mathrm{Na}$ Europa, as possibilidades de alteração de prenome e gênero para as sujeitas e os sujeitos que as demandem sob a ótica do que se chama de transexualidade são garantidas há muitos anos. Países como Alemanha, Itália, Noruega, Portugal, Suécia, Espanha, Turquia e Reino Unido estão nesse rol. Há nações que efetuam as alterações via medidas administrativas, desde que as sujeitas e os sujeitos cumpram alguns requisitos, como no caso da Suécia, por 
exemplo: comportar-se no gênero que se sente; ser maior de dezoito anos; ser solteira e a exigência de ser incapaz de gerar filhos ${ }^{98}$.

Na Alemanha, o livre "desenvolvimento da personalidade" (Entfaltung der Personlichkeit), princípio básico presente no ordenamento alemão, juntamente com a "Lei sobre a mudança de nome e determinação da identidade de gênero em casos especiais (TSG) ${ }^{99 ",}$,admitem a intervenção cirúrgica e a retificação de prenome e gênero nos registros civis desde as décadas de 1970-80, sob determinados requisitos, dentre eles: dois pareceres médicos; três anos de vivência no gênero pretendido e ser infértil (DINIZ, M., 2001, p. 236 e VIEIRA, 2004, p. 119apud Mendes Gonçalves: 73-74).

$\mathrm{Na}$ Itália, a legislação específica surgiu para evitar incertezas. Embora não imponha requisito algum para autorizar a mudança dos dados registrais, preocupou-se com o estado civil da pessoa, ou seja, com os terceiros. Se a pessoa for casada deve haver a dissolução do casamento, ao se adequar o gênero no registro civil da sujeita ou sujeito.

$\mathrm{Na}$ Espanha os princípios da dignidade da pessoa e o livre desenvolvimento da personalidade utilizados em conjunto com os direitos individuais já compunham o panorama permissivo às mudanças registrais há muitos anos. Desde o ano de 2007 uma lei específica autoriza que as cidadãs e os cidadãos possam, a partir de um pedido pessoal, alterar o prenome e o gênero nos documentos civis, independentemente de haver realizado as cirurgias de adequação. Porém, o tratamento hormonal com no mínimo dois anos é requisito para as modificações civis, salvo se houver motivos de saúde ou de idade indicando não ser possível a hormonoterapia.

\footnotetext{
${ }^{98}$ Como se verá adiante, em diversos países europeus há a expressa exigência da esterilidade como condição de acesso às modificações físicas ou jurídicas. Não conseguimos encontrar referências seguras sobre qual a natureza e motivação de tal exigência e que implicações poderia haver na vida das pessoas.

${ }^{99}$ Gesetzüber die Änderung der Vornamen und die Feststellung der Geschlechtszugehörigkeit in besonderenFällen (de:Transsexuellengesetz - TSG)
} 
A Dinamarca admite as alterações documentais por medidas administrativas após dois anos de acompanhamento em serviço de psiquiatria vinculado ao Estado, além de haver passado pelas cirurgias.

Já na Suíça, o julgador faz papel de legislador, ao interpretar artigo do Código Civil para permitir que o reconhecimento de um erro registral promova a modificação. Para o tribunal suíço, o sexo não é determinado apenas pelo corpo, mas também pela alma (Vieira, 2004 apud Mendes Gonçalves: 75).

Na Holanda desde 1985 a legislação prevê que não apenas o nacional, mas também o estrangeiro (que tenha domicílio durante ao menos um ano e visto de residente) possa adequar o prenome e o gênero. Assim, como os países acima, a pessoa deve ser solteira e incapaz de gerar.

O Reino Unido possui legislação específica desde 2004, a Gender Recognition $A c t^{100}$. Na década de 1970, os debates sobre casamento fomentaram a necessidade da criação da lei, pois naquela época o casamento anterior impedia que se mudasse o "status de gênero" mesmo que houvesse passado por cirurgias. Assim, os casais continuaram a ser, ao menos nos documentos, formados por homem e mulher. Os casos levados ao Tribunal Europeu de Direitos Humanos propiciaram a condenação do Reino Unido por violar os direitos à privacidade e à vida familiar em 2002, ocasionando a criação da lei. Aquela norma reconhece o gênero afirmado pelo indivíduo mesmo antes das cirurgias. Entretanto, atrelam as alterações registrais a um laudo médico atestando a disforia de gênero e comprovação de que se vive por dois anos no gênero pretendido, tencionando continuar a sê-lo até a morte.

De acordo com Mendes Gonçalves, a França merece destaque, pois foi a primeira e única iniciativa de Estado-nação a não considerar "transexualismo" como doença, requerendo sua retirada como enfermidade dos compêndios médicos franceses, mesmo que a Organização Mundial de Saúde (OMS) ainda mantenha tal classificação (: 77). A manobra política da então ministra da saúde ocasionou

\footnotetext{
${ }^{100}$ Ver em: http://www.legislation.gov.uk/ukpga/2004/7/contents Último acesso em 06/02/15.
} 
oficialmente a supressão da patologia do rol de troubles précoces de l'identité de genre (desordens de identidade de gênero precoce), que por sua vez era classificada dentro de affections psychiatriques de longue durée (transtornos psiquiátricos de longo prazo). (Perrin 2010 apud Mendes Gonçalves: 77-78). Organizações civis francesas, apesar de reconhecerem o avanço, temeram não haver mais o reembolso dos procedimentos pelo sistema de seguridade social. Outro aspecto importante é que a alteração nos documentos civis continua a exigir a cirurgia de adequação genital precedendo o pedido. Também se exige que as pessoas se submetam à esterilização durante a cirurgia, como visto acima em diversos outros países.

Para finalizar o breve levantamento legislativo dessas questões nos países europeus, o autor discorre sobre dois órgãos supranacionais que têm contribuído para o acesso das sujeitas e dos sujeitos aos direitos: o Conselho da Europa $^{101}$ e o Tribunal Europeu dos Direitos Humanos ${ }^{102}$, esse último utilizado para modificar alguma decisão desfavorável de país signatário, ocasionando condenações nos países para criar ou rever legislações, como no caso do Reino Unido. Mendes Gonçalves lamenta que apesar das legislações europeias normatizarem instrumentos para a garantia de direitos, termos ou expressões médicas como "transtorno", "disforia" ou "diagnóstico" ainda têm precedência aos sujeitos (: 82).

Voltando à realidade brasileira e como visto acima, não há legislação específica que regule a matéria. Magistrados, promotores e advogados utilizam-se, basicamente, de dois princípios constitucionais: a dignidade da pessoa humana e a

\footnotetext{
${ }^{101}$ De acordo com a NR do autor à página 78: "O Conselho da Europa é a organização international da Grande Europa (47 Estados membros, todos os países europeus com exceção do Cazaquistão) cujo objetivo é promover a democracia, os Direitos Humanos, a identidade cultural européia e a busca de soluções aos problemas das sociedades da Europa. Sua sede é em Estrasburgo, tendo sido fundado em 5 de maio de 1949 pelo Estatuto de Londres. É importante não confundir o Conselho da Europa com: o Conselho da União Europeia, que é o órgão político onde são representados os governos nacionais dos países da União europeia; e o Conselho Europeu, que é o nome das reuniões onde é decidida a política geral da União europeia (CONSELHO DA EUROPA, 2012)".

102 Ver em: http://www.echr.coe.int/Pages/home.aspx?p=home Último acesso em 06/02/2015.
} 
promoção do bem-estar de todos (ou de não discriminações) ${ }^{103}$ associados à Lei de Registros Públicos, quando o prenome exponha a pessoa ao ridículo ou para substituí-lo por apelido público notório.

\subsection{Fundamentos religiosos no Poder Judiciário.}

Como já visto acima, nem sempre a lei é a fonte para as decisões judiciais. Como dito há pouco, o falecido ministro Carlos Alberto Menezes Direito, do Superior Tribunal de Justiça (STJ) - frise-se a maior corte do País a decidir definitivamente esses e diversos outros casos que envolvam "interpretação da legislação infraconstitucional"104 - católico fervoroso, utilizou-se de argumentos de moral religiosa para fundamentar "juridicamente" ${ }^{105}$ a decisão que se tornou o referencial de como essas questões devam ser julgadas em todo o Brasil. $\mathrm{O}$ acórdão daquele Recurso Especial ${ }^{106}$ contém no voto do ministro elementos religiosos ou metafísicos considerados "jurídicos" por ele e seus pares para a decisão lavrada. Explana o ministro em sua decisão (litteris):

No clássico "A Natureza do Bem" (De Natura Boni), escrito para enfrentar os maniqueus por volta do ano de 400, Santo Agostinho (354 a 430), ensina que "toda e qualquer natureza enquanto natureza é sempre um bem - não pode provir senão do supremo e verdadeiro Deus, porque o ser de todos os bens, tanto os que pela sua excelência se aproximam do Sumo Bem como os que pela sua simplicidade se afastam d'Ele, não pode provir senão do Sumo Bem. Por conseguinte, todo e qualquer espírito está sujeito a mudança, e todo e qualquer corpo provém de Deus - e a espírito e matéria reduz-se toda natureza criada. Segue-se daí necessariamente, que toda e qualquer natureza ou é espírito ou é corpo. O único espírito

\footnotetext{
${ }^{103} \mathrm{O}$ artigo 1ํ, inciso III, da Constituição Federal de 1988 diz que: "A República Federativa do Brasil, formada pela união indissolúvel dos Estados e Munícipios e do Distrito Federal, constitui-se e Estado Democrático de Direito e tem como fundamentos: [...] III - a dignidade da pessoa humana;". O artigo $3^{\circ}$, inciso IV, afirma que: "Constituem objetivos fundamentais da República Federativa do Brasil: [...] IV - promover o bem estar de todos, sem preconceitos de origem, raça, sexo, cor, idade e quaisquer outras formas de discriminação."

${ }^{104}$ Ver: competências do STJ no artigo 105 da Constituição Federal de 1988.

${ }^{105}$ Marcus Faro de Castro faz uma crítica aos argumentos políticos, morais ou metafísicos com pretensões "jurídicas" em diversos ordenamentos. Na obra "Formas jurídicas e mudança social: interações entre o direito, a filosofia, a política e a economia" (2012) o autor analisa a partir de uma retrospectiva histórica desde a Antiguidade Clássica aos dias de hoje o quanto de político e moral são formadas as decisões judiciais.
}

106 "REsp" ou "Recurso Especial" é uma ação judicial específica, prevista no artigo 105 da Constituição Federal de 1988, direcionada ao Superior Tribunal de Justiça, com o objetivo de "corrigir" alguma questão legal debatida nos autos mas omitida, ferida ou denegada nas instâncias inferiores. 
imutável é Deus; o espírito sujeito a mudança é uma natureza criada, ainda que seja superior ao corpo. Por sua vez, o corpo não é espírito, nem sequer o vento, porque, conquanto nos seja invisível e por isso o chamemos, em sentido figurado, espírito, Ihe sentimos perfeitamente os efeitos"(tradução de Carlos Ancêde Nougué, Ed. Sétimo Selo, 2a ed., 2006, págs. 3 e 5).Julgamentos dessa natureza precisam ser postos sempre debaixo do amor pela humanidade, naquele sentido agostiniano da natureza criada, ou, na civilização moderna, na avalanche dos questionamentos entre os que crêem e os que não crêem, debaixo do critério da igualdade de direitos e da fecunda compaixão que deve unir todos os homens na realização plena de sua natureza pessoal e social. Com isso, afasta-se, desde logo, qualquer tipo de preconceito, de discriminação, posta a questão no plano da realidade jurídica, sem perder de vista a integralidade do ser do homem na sua dignidade, na sua felicidade existencial e espiritual. Somos todos um só homem quando nos encontramos iguais em nossa natureza criada. (Grifos originais).

O trecho acima foi integralmente transcrito na sentença de alteração de prenome e gênero de Bruxa Malvada do Oeste e, como decisão que põe termo a algum dissídio coletivo de ações (ao menos até que haja entendimento reiterado e pacificado que enseje rever tal entendimento) é replicado em diversas outras decisões de sujeitas e sujeitos cuja demanda seja a alteração de prenome e/ou gênero ${ }^{107}$.

Além dos argumentos pretensamente jurídicos de origem religiosa, há também naquele acordão a construção moral de gradação valorativa relativa às sujeitas, posições sociais "naturais", admiração e consideração, em oposição "às outras" que não as têm, como quando o ministro falecido discorre sobre a decisão do TJRS que compara as sujeitas que alteraram as genitálias com mulheres inférteis:

Não creio que os argumentos postos no acórdão do Tribunal de Justiça do Rio Grande do Sul tenham substância capaz de justificar a conclusão que acolheu, particularmente com a infeliz comparação com a mulher que por qualquer patologia não pode gerar. Aquela que não pode gerar tem a mesma benção da sua natureza daquela que pode. Ao dom da criação, que homem e mulher repartem, com a fecundação, fruto de amor e entrega, de doação e unidade, não se nega a origem nascida nem se esconde fato resultante de ato judicial. Não se trata de ato submetido ao registro civil. Não se trata de modificação da sua natureza gerada. (Grifos não originais).

\footnotetext{
107 Tal decisão foi citada no todo ou em partes nos fundamentos dos acórdãos do STJ: SE 4.179/IT; SE 2.732/IT; REsp 737.993/MG; REsp 1.043.004/RS; REsp 876.672/RJ, entre outros. O único que não faz menção a esse julgado mesmo sendo posteriormente prolatado é o REsp nำ1.008.398/SP.
} 
Depreende-se das palavras do ministro que: a) cotejar mulheres infecundas com sujeitas que realizaram cirurgias de adequação é "infeliz comparação", pois as primeiras têm as bênçãos da natureza e as segundas, não; b) homens e mulheres são úteis biológica e socialmente, já as sujeitas "negam" a origem de nascimento e "escondem" fato vinculado a ato judicial, dando a perceber que "fugiriam" "dos desígnios da natureza".

Interessante notar o giro argumentativo na forma como o ministro fecha a decisão, ao voltar os argumentos à própria origem do pedido, justificando a grafia da mudança no assento de registro público para não haver "preconceito, discriminação" contra a sujeita demandante (Litteris):

O recorrido quis seguir o seu destino, e agente de sua vontade livre procurou alterar no seu registro civil a sua opção, cercada do necessário acompanhamento médico e de intervenção que the provocou a alteração da natureza gerada. Há uma modificação de fato que se não pode comparar com qualquer outra circunstância que não tenha a mesma origem. 0 reconhecimento se deu pela necessidade de ferimento do corpo, a tanto, como se sabe, equivale $o$ ato cirúrgico, para que seu caminho ficasse adequado ao seu pensar e permitisse que seu rumo fosse aquele que seu ato voluntário revelou para o mundo no convívio social. Esconder a vontade de quem a manifestou livremente é que seria preconceito, discriminação, opróbrio, desonra, indignidade com aquele que escolheu o seu caminhar no trânsito fugaz da vida e na permanente luz do espírito. Não se pode esconder no registro, sob pena de validarmos agressão à verdade que ele deve preservar, que a mudança decorreu de ato judicial, nascida da vontade do autor e que tornou necessário ato cirúrgico complexo. Trata-se de registro imperativo e com essa qualidade é que se não pode impedir que a modificação da natureza sexual fique assentada para o reconhecimento do direito do autor. (Grifos não originais).

Pelos trechos, o ministro considerava na "escolha" da indivídua as consequências do seu ato, por isso a publicização não guarda nenhuma relação com respeito à vontade, mas com a culpa ou a responsabilização da requerente quando na visão daquele julgador ela não "seguiu o caminho da natureza". Ao identificar no registro civil da sujeita as modificações havidas o ministro decidiu em total dissonância aos princípios da dignidade da pessoa e da proibição de discriminação, já que marcará e exibirá exatamente aquilo que ela não deseja que seja público, além de por si só, proporcionar-lhe discriminações e preconceitos. 
"Alteração da natureza gerada", "ferimento do corpo", "seguir seu destino", "agressão à verdade" são todos argumentos de cunho pessoal e religioso. Todos dependentes da visão de mundo que uma ou outra religião impõe aos seus adeptos, aos simpatizantes e mesmo aos que não a seguem, mas são submetidos aquele regime. Em relação aos julgadores, sejam juízes, desembargadores ou ministros, as decisões são tomadas não apenas com o auxílio das pretensões contidas nos termos nativos da "imparcialidade" e "neutralidade", mas igualmente com a sempre presente convicção pessoal do julgador, como discorre a professora Regina Lúcia Teixeira Mendes (2011):

Isto porque, a subjetividade agregada às decisões judiciais são constitutivas da estrutura do eu dos julgadores, e se acham mescladas por aspectos tradicionais, institucionais e do próprio habitus que caracteriza o campo do direito estudado $(: 155) .{ }^{108}$

Como se viu no começo do capítulo, os pedidos das sujeitas são para a alteração de prenome e/ou gênero nos documentos civis. O Judiciário lida com essas demandas acolhendo o pedido de forma transversa, justificando as mudanças pretendidas pela categoria "transexual", invariavelmente, embora nem sempre seja esse o pedido ou o sentido do reconhecimento demandado. A identidade da sujeita é sistematicamente ignorada ou propositalmente desconsiderada, pois se operam ou deferem pleitos somente a "transexuais" e não em mulheres. Novamente, trata-se de um falso ou pseudoproblema. Além do mais, a decisão frequentemente é baseada em valores morais ou religiosos de quem decide o que obviamente não se permite contestar. Fato é que mesmo diante de uma decisão positiva - mero ganho material para as sujeitas - sobra razoável parcela de elementos que ficam sem resposta estatal, como o reconhecimento da identidade real e vivida pela indivídua. Não se sabe se uma lei específica ou ato legal com força normativa conseguiria satisfazer ambas as demandas. Porém, a ausência de norma corretamente voltada às resoluções dos problemas não tem permitido que mulheres de fato sejam

\footnotetext{
${ }^{108}$ Regina Lúcia Teixeira Mendes, na obra "Do princípio do livre convencimento motivado: legislação, doutrina e interpretação de juízes brasileiros." (Rio de Janeiro: Lumen Juris, 2011) analisa as formas como os juízes decidem no Brasil por intermédio de entrevistas pessoais a diversos magistrados, apresentando um panorama amplo de interpretações e significados acerca do uso da categoria legal "livre convencimento motivado" pelos atores judiciais.
} 
consideradas mulheres, mas contra suas vontades, são sempre conhecidas como "transexuais".

\section{Identidade trans e o fetiche acadêmico pela "TransRevolucionária".}

Inspirado nos movimentos feministas das décadas passadas ao tomar a ofensa, insulto ou desqualificação lançada assumindo-a numa nova postura ${ }^{109}$, 0 movimento LGBTTT utiliza a estratégia de reapropriação da identidade patológica "trans" com o objetivo da ressignificação do termo frente a toda a sociedade. Para aquele grupo, "transexual" é:

Pessoa que possui uma identidade de gênero diferente do sexo designado no nascimento. Homens e mulheres transexuais podem manifestar o desejo de se submeterem a intervenções médicocirúrgicas para realizarem a adequação dos seus atributos físicos de nascença (inclusive genitais) e sua identidade de gênero construída. $(2010: 17)^{110}$

Portanto, na sigla do movimento "LGBTTT", um dos "T" situa-se para representar as/os "transexuais". Naquele grupo, a identidade "trans" ou "transexual" é adicionada após o termo "homem" ou "mulher", como um adjetivo qualificador. Assim, para aquele movimento "homem transexual" é o indivíduo nascido com vagina e vulva, que menstrua e, em tese, poderia gerar filhos; e "mulher transexual" é a sujeita nascida com pênis e escrotos. Essa estratégia de inserção e incidência político-social é adotada pelo movimento como gay pride ${ }^{111}$, ou seja, ter orgulho de

\footnotetext{
${ }^{109}$ A exemplo da "Marcha das Vadias" ou "Slut Wlak", movimento de abrangência mundial realizado por diversos coletivos de mulheres. A reapropiação do termo "vadia" guarda lógica com a estratégia de assumir e resignificar a palavra tornando sua conotação, antes negativa, como positiva e libertária. Para saber mais sobre esse movimento e suas implicações nos campos virtuais ver a etnografia de Michele Faise de Almeida, dissertação de mestrado apresentada em 2014 à Faculdade de Direito da UnB: "Direitos, demandas e narrativas das mulheres: Notas etnográficas dos discursos na arena jurídica e na militância online/off-line".

Para saber mais sobre o Movimento Internacional Marcha das Vadias, ver em: http://www.observatoriodegenero.gov.br/menu/noticias/marcha-das-vadias-chega-ao-brasil// Último acesso em:05/11/14.

110 Ver em: http://www.abglt.org.br/docs/ManualdeComunicacaoLGBT.pdf Último acesso em 05/11/14.

${ }^{111}$ A enciclopédia livre, Wikipedia traz em seu vocábulo "gay pride" como: " a postura positiva contra a discriminação e a violência em desfavor de lésbicas, gays, bissexuais e transgêneros (LGBT) para promover a sua autoafirmação, dignidade, igualdade de direitos, aumentar sua visibilidade como um grupo social, construir uma comunidade, e celebrar a diversidade sexual e de variedade de gênero.
} 
ser "trans", diferente, incomum, destacada de homens e mulheres ditos "comuns". Importante lembrar que nesses termos o que se nomeia como transexualidade representa uma das possibilidades de manifestação da "identidade de gênero", não guardando relação direta com a "orientação sexual."

Na mesma linha do "orgulho" ao assumir a diferença, grande parte dos trabalhos acadêmicos que se filiam aos que se chama de "estudos queer", enfatiza o que acreditam ser o caráter potencialmente "subversivo" da categoria "transexual", assim como das identidades "travesti" e "transgênero ${ }^{113 " . ~ E s s a ~ " s u b v e r s a ̃ o " ~ e s t a r i a ~}$ ancorada nas plasticidades dos jogos de corpos, gêneros e sexualidades, composições diversas das possibilidades dos gêneros feminino e masculino, parodiados por certos sujeitos e identidades.

Com a frase de impacto "vamos explodir os gêneros", a socióloga Berenice Bento ${ }^{114}(2003)$ espera e planteia pelas "TransRevolucionárias" ou "Supertrans" butlerianas dispostas e capazes a sacrificar a própria existência para satisfazer o gosto pessoal de pesquisadores ao desbravar e "revolucionar" campos onde mulheres e homens tolhidos pelo que nomeia de "heteronormatividade" ${ }^{115}$, não teriam coragem de ir. A preocupação de Bento situa-se na denúncia do caráter pré-

Orgulho, ao contrário de vergonha e estigma social, é a perspectiva predominante que reforça a maioria dos movimentos de direitos LGBT em todo o mundo." (tradução nossa).

Ver em: http://en.wikipedia.org/wiki/Gay pride\#cite note-Massachusetts-42 último acesso em: 03/03/15.

${ }^{112}$ Para os movimentos LGBTTT, as identidades de gênero são três: travesti, transexual e transgênero. Já as orientações sexuais são também em número de três: homossexual, bissexual e heterossexual. Ver em: http://www.abglt.org.br/docs/ManualdeComunicacaoLGBT.pdf

Último acesso em: 03/03/15.

${ }^{113}$ A ativista LGBTTT, Letícia Lanz em sua página pessoal, traça um minucioso estudo sobre a palavra transgênero.

Ver em:

http://www.leticialanz.org/transgenero-um-historico-do-termo/

Último acesso em: 03/03/15

${ }^{114}$ A socióloga e atual professora da Universidade Federal do Rio Grande do Norte/RN começou seus estudos em masculinidades, na graduação e no mestrado. No doutorado trabalhou com a temática transexual. Ver em:

http://buscatextual.cnpq.br/buscatextual/visualizacv.do?metodo=apresentar\&id=K4795652T8

Último acesso em: 03/03/15.

115 Termo que utiliza inspirada em Judith Butler na obra "Problemas de gênero: feminismo e subversão da identidade", para descrever a heterossexualidade compulsiva, "sexualidade hegemônica", "norma heterossexual" (Butlerapud Bento, 2003: 84). 
discursivo essencializador sobre as relações binárias de diferenças entre mulheres e homens no que chama de "heterossexualidade dominante", estimulando a ausência de compreensão dos "[...] sujeitos que transitam entre o masculino e o feminino [...]", tais como: "os transexuais", "os travestis", "as drag queen", "os drag king" (: 74). A autora busca entender "[...] as práticas de sujeitos que se constroem fora dessa binariedade" (idem) a partir das problematizações de Butler, especialmente, na obra "Gender and Trouble" de 1999 (: 77). Segundo ela, o que se conseguiria com o uso do termo queer, nas definições de Butler por Bento, colocando o sujeito diferente, dissonante, em posição de degradação:

Queer adquiere todo su poder precariamente a través de la invocación reiterada que lo relaciona com acusaciones, patologías e insultos. Se trata de una invocación a través de lacual se ha estabelecido un vínculo entre comunidades homofóbicas (Butler apud Bento, 2003: 78)

Em sua leitura dos estudos queer, a autora elenca alguns dos pressupostos considerados nessa categoria, tais como: a "sexualidade como um dispositivo"; as identidades de gênero em seu caráter performático; o "alcance subversivo das performances e das sexualidades fora das normas de gênero", entre outros (: 78). Bento enxerga em identidades singulares como a do performer dragking inglês Del LaGrece Volcano (que se autodenomina um "terrorista de gênero - "(Hoy) soy un terrorista del género, una mutación intencionada, un/a intersexo a través del diseño"116) alto potencial subversivo. Assim, a "performatividade queer" de Butler entra em cena para "criar fissuras, contra-discursos, a exemplo dos drag $k^{k i n g " 117}$ (: 92). Ao que parece, Bento pretende pela mesma ótica ver as/os transexuais, mesmo sabendo que não é assim que as/os sujeita/os se veem, dizem de si e desejam ser vista/os.

\footnotetext{
${ }^{116}$ Trecho extraído de Bento (: 82-83). Em sua página na internet o artista acrescenta mais sobre sua identidade/personalidade: "A gender abolitionist. A part time gender terrorist." Para saber mais sobre 0 performer e sua história, ver em: http://www.dellagracevolcano.com/statement.html último acesso em: 03/03/15.

${ }^{117} \mathrm{Em}$ sua tese, Bento especifica mais essa expressão na agência do indivíduo em comparação com o habitus proposto por Bourdieu, nesses termos: "quando se fala de performances de gênero e na capacidade do agente atuar interpretando as normas, se está afirmando que os sujeitos têm margens de interpretação e que há espaços para a produção de contra-discursos e fissuras na ordem de gênero." (: 94).
} 
Em toda a tese, uma das preocupações de autora é com o que chama de heterossexualidade compulsória e normativa propiciadora de uma "assepsia dos gêneros" e produtora de corpos dimórficos e sem ambiguidades (: 127). Crê que para muitos "transexuais" não será a cirurgia que garantirá a coerência identitária almejada, porém para outros as intervenções cirúrgicas propiciarão a ascendência à condição humana. Em ambas as situações são o "dimorfismo sexual" e a "heterossexualidade natural dos corpos" os balizadores para a concessão ou não dos pedidos ${ }^{118}(:$ 158).

Ao final, Bento discute se existiria uma "identidade transexual", explicitando as dificuldades de se delimitar características gerais que permitam compartilhar o que chama de "experiência transexual" como "identidade coletiva", sobretudo se o marcador identitário for a cirurgia de adequação, pois então a identidade seria temporalmente delimitada. Questiona-se a autora: -"Depois da cirurgia, continuar-se-á um/a transexual?" (: 215). Declara então que para ela seriam as "[...] posições transexuais (e não "identidade transexual") [...]" o problema (: 225). Ao que parece a expectativa revolucionária não vingou. Pois nas falas das e dos entrevistados a pesquisadora não encontrou o eco subversivo na intensidade de suas suposições teóricas, concluindo o trabalho num tom de desapontamento.

A pesquisadora Flávia do Bonsucesso Teixeira (2009), em suas palavras, "ao seguir as pistas" deixadas por Bento, discorre em sua tese o que considera ser uma excessiva ênfase na "heterossexualidade dominante" e na "correção sexual" para a performance de gênero dessa categoria ${ }^{119}$. A autora analisou os processos de pessoas que demandavam as cirurgias de alteração da genitália, entre 20042008, no extinto "Programa de Transgenitalização" da Promotoria de Justiça - PRÓ-

\footnotetext{
${ }^{118}$ Bento expõe detalhadamente no seu trabalho as duas concepções vigentes "que fundamentam o dispositivo da transexualidade" nas ciências médico-psicológicas, são elas: o "transexual stolleriano", em referência ao psicanalista Robert Stoller; e o "transexual benjaminiano", pensando a partir das teses do endocrinologista Harry Benjamin. Ambas as concepções buscam a partir de critérios rígidos identificar o "transexual de verdade" (: 131-159). Para essa dissertação, essas teorias não têm relevância uma vez que aqui se privilegia as trajetórias das interlocutoras e não as teorias dos "especialistas".

119 A autora explica o uso das aspas no termo transexual como marcador de instabilidades da categoria que serviria para ela, então, como: a "chave para responder provisoriamente a necessidade de escrever sobre mulheres e homens (transexuais)" (: 31$)$.
} 
VIDA, do Ministério Público do Distrito Federal e Territórios - MPDFT ${ }^{120}$, entrevistando ainda as/os requerentes em diversos ambientes, inclusive no "Programa Transexuais", grupo terapêutico ainda em funcionamento precário no Hospital Universitário de Brasília - HUB/UnB.

O estudo de Teixeira é bastante similar ao de Bento quanto à análise das entrevistadas e dos entrevistados que nomeia como "mulheres e homens (transexuais)" e suas inserções nos campos médico-psicológicos e da militância LGBTTT. Também se afigura parecido quando pretende identificar as fronteiras entre as "mulheres (transexuais)" e as travestis mais preocupada com as eventuais similitudes do que com as diferenças. Em alguns trechos, parece haver uma dificuldade de sintonia com os horizontes das entrevistadas (ou mesmo uma recusa em acreditar nessa possibilidade) quando percebe que as "mulheres (transexuais)" não desejam ser "pares idênticos" das identidades travestis e demais LGBTTT, ao contrário, as pesquisadas parecem querer ser apenas mulheres:

[...] problematizo as posições desejadas e outras recusadas pelas mulheres (transexuais). Demonstro que, ao reivindicarem a posição de mulheres, elas promovem uma separação significativa com o movimento das travestis, que não demandam tal reconhecimento. Num segundo movimento de demarcação de espaços, entendo que a reivindicação da substituição do termo transexual por mulheres que vivenciam a transexualidade é utilizada como uma estratégia para se distanciarem do movimento LGBTT. (Teixeira, 2009: 183).

Em outro trecho:

Assumidas as posições identitárias que separam as travestis e as mulheres (transexuais), a reivindicação a seguir parecia ser a de se afastar do movimento LGBTT. Para tal, uma das estratégias seria a de abandonar o termo transexual. (Idem: 188).

Entretanto, ao contrário de Bento, Teixeira parece ter escutado melhor as definições das interlocutoras e dos "especialistas" sobre o que se nomeia por transexualidade, conceituando-a assim:

A transexualidade pode ser lida como uma experiência de mobilidade que carrega um desejo de finitude. Alcançar a "outra margem do rio" e declarar o fim desta passagem. Se para muitos/as esse lugar é atribuído no momento do nascimento, em função de uma genitália aparente, para os/as integrantes dessa tese tal posição depende de uma conquista. A questão maior é que a armadilha desse discurso

\footnotetext{
${ }^{120}$ Teixeira avisa que esse programa foi suspenso em 2004. No sítio do MPDFT não há mais nada que remeta aquele programa.
} 
reside no caminho escolhido para alcançar a outra margem do rio: a imposição da cirurgia. (Teixeira, 2009: 193).

A autora insiste no que chama de "armadilha" a escolha pela cirurgia como algo negativo: "a finitude da condição transexual é declarada como um apaziguamento garantido pela cirurgia que asseguraria o fim desta passagem." (: 196). Mesmo após acompanhar diversas sujeitas em vários espaços, parece não conseguir compreender porque a necessidade das cirurgias na vida das entrevistadas. Em outras palavras, mesmo sendo uma "armadilha", para grande parte das interlocutoras daquele estudo, a cirurgia tem caráter fundamental, inclusive na construção da identidade.

Ponto fundamental no trabalho, não suficientemente problematizado, situa-se na observação de Teixeira ao notar que as suas entrevistadas e os seus entrevistados a enxergavam como uma agente com saber-poder para autorizar ou denegar um pedido:

O desenrolar da reunião, associado à solicitação do grupo para que eu não mostrasse o conteúdo das fitas ao Promotor, apontava para uma percepção de que a minha imagem estava impregnada pelo discurso oficial (do promotor, da academia, de saberes que autorizavam). (Teixeira, 2009: 26).

Nesse sentido, pode-se presumir que como as/os interlocutoras/res demandavam a cirurgia com considerável esforço (com bem notado pela autora) e aparentemente imaginavam que Teixeira pudesse ajudar ou atrapalhar os objetivos, agiram e discursaram de modo a não deixar dúvidas de que eram "transexuais verdadeiros", inclusive enfatizando os estereótipos.

Nas considerações finais, a autora desabafa:

A temática da transexualidade explicita as tensões entre os termos: sexo, gênero e desejo. Desafia a noção de uma identidade originária, natural e estática. Pode ser um veículo para pensar outras masculinidades/feminilidades, inclusive redesenhando outras maternidades e paternidades possíveis. Mas toda essa possibilidade subversiva se desenvolve num cenário de disputas em que a retórica essencializante sobre natureza constrói, também, uma experiência da transexualidade como emblema de sofrimento, e as pessoas representadas como vítimas de um engano da natureza. (Teixeira, 2009:227). 
Uma das interpretações possíveis nos trechos acima, inspiradas por Butler e sua expectativa de "explosão de gênero", é de que as entrevistadas e os entrevistados vivem em autoengano. As pesquisadoras parecem esperar que suas interlocutoras algum dia perceberão o quanto estão equivocadas na forma em que vivem suas vidas, pois, se conhecessem a literatura queer certamente fariam diferente: transgrediriam as "normas de gênero" naqueles termos.

O questionamento que se deve fazer é:será que todas/os as quais se referem como "trans" ou "transexuais" querem mesmo revolucionar alguma coisa? Esse é o discurso delas/es? O que faz com que pesquisadores armados dos estudos queer se interessem tanto pela categoria "transexual" investindo esforços na concretude das rupturas de gênero? Como se verá ao final dessa etnografia, ao menos as mulheres escutadas aqui não se definem como "transgressoras" nos termos esperados por essa linha acadêmica. Evidentemente que há sujeitas e sujeitos que se identificam e se autodefinem como "transexuais". Mas uma lida atenta às falas de algumas dessas pessoas pode descortinar que o que se deseja não é a ênfase "trans", mas a superação dos problemas práticos - cirúrgicos e jurídicos - que "normalizariam" os indivíduos ${ }^{121}$. Então, a "subversão", a "revolução" e o desapontamento são mais os votos depositados pelas pesquisadoras, estudiosas, "especialistas", acadêmicas do que a vontade real das sujeitas e dos sujeitos.

Outro ponto a se analisar é que a busca pela cirurgia, a alteração do prenome e gênero não são para manter as sujeitas sob alguma "bandeira" LGBTTT. $\mathrm{Na}$ verdade, basta ouvir, escutar corretamente, e se perceberá que as sujeitas e os sujeitos almejam exatamente o oposto: algum nível de estabilidade em um dos polos da inteligibilidade dos gêneros hoje existentes. Realizam as cirurgias, as alterações jurídico-sociais para certa acomodação ou adequação à condição feminina e de mulher, nas sujeitas; e masculina e de homem, nos sujeitos são metas claras. Por isso, acreditamos haver a necessidade de se investigar mais a fundo a categoria autoafirmada "transexual" etnograficamente, através da escuta atenta às sujeitas e

$\overline{121}$ A interlocutora Maga Patalógica afirma categoricamente que "se conhecessem essas pessoas jamais as chamariam de transexuais". 
aos sujeitos, que a avocam para tentar uma aproximação compartilhada entre sujeitas e pesquisadoras.

Por fim, há ainda no movimento "transexual" fora do Brasil, uma discussão acerca da intransponibilidade entre o que seriam dois grandes grupos de indivíduos: "as pessoas transexuais" e as "pessoas cissexuais" ${ }^{122}$. Para essa corrente, os primeiros estão socialmente em desvantagens já que os segundos nasceram com mente e corpo em consonância de gênero, ou seja, não precisariam ou desejariam adequações genitais ou outras medidas de apoio ou reparação.

\subsection{A identidade travesti.}

Como se verá nas falas das sujeitas desse estudo, frequentemente há a necessidade de se demarcar os limites entre identidades. As mulheres interlocutoras dessa dissertação não se definem como travestis, mas ao contrário, diferenciam-se radicalmente daquelas em termos de identidade.

Don Kulick (2008) na rica etnografia que acompanha a vida das travestis que se prostituem em Salvador/BA explana sobre as características gerais daquela identidade. Algumas delas se definem como homossexuais efeminados, gays, bichas $^{123}$,viados e monas ${ }^{124}$. Muitas têm iniciação sexual quando muito jovens (em torno de 11-13 anos de idade). Utilizam-se de hormônios feminizantes e injetam silicone líquido no corpos para aumentar quadris, nádegas, coxas, joelhos, e mais raramente, os seios (: 86-99). Kulick relata que nas suas experiências com as travestis acreditava que elas buscavam corpos femininos por "se sentirem como mulher". Entretanto, escutando-as atentamente surpreendeu-se:

\footnotetext{
${ }_{122}$ Para maiores informações ver o trabalho da ativista estadunidense e mulher transexual Julia Serano no livro "Whipping girl: a transexual woman on sexism and the scape go a ting of femininity". Ver em: https://books.google.com.br/books?id=fR5ji5h5g1MC\&printsec=frontcover\&dq=Whipping+Girl\&hl=ptBR\&sa=X\&ei=Ey 2VKqoDcewsASP94D4Dw\&ved=0CB0Q6AEwAA\#v=onepage\&q=Whipping\%20Girl $\& \mathrm{f}=\mathrm{false}$ Último acesso em: 03/03/15.

${ }^{123}$ Kulick (2008: 80-82).

${ }^{124}$ Kulick (2008: 216).
} 
A mim, nenhuma delas jamais disse que era uma mulher presa em um corpo de homem - mesmo quando eu, já confuso e exasperado para compreender, às vezes chegava a sugerir tal resposta. Ao contrário, há um consenso fortemente estabelecido entre as travestis de Salvador: para elas, qualquer travesti que se diz ou se considera mulher tem problemas mentais. Travesti não é mulher e não pode ser mulher, dizem umas às outras, porque Deus as fez homens. (: 100).

Uma de suas entrevistadas sintetiza: "Eu nasci homem e vou morrer homem. Como eu posso ser mulher um dia, se eu nasci homem? Se eu por acaso me castrasse e pusesse uma buceta, isso faria de mim uma mulher?". O autor destaca ainda que há hostilidades e incompreensões por parte das travestis contra "os transexuais", aumentando as distâncias entre aquelas categorias. (: 101-103). Em relação às mulheres e orientadas por preconcepções atávicas, uma das suas interlocutoras travestis tem o seguinte olhar: "Mulher é uma coisa natural, mulher é nature/ é naturalidade. Não precisa você se... quebrar a mão, você jogar cabelo, porque isso não é coisa de mulher. Coisa de mulher é naturalidade." (: 208). Segundo o autor, os jogos de "naturalidade" (presentes nas mulheres) e "artificialidade" (trazidas pelas travestis) fazem parte do quotidiano das entrevistadas travestis, seja na vida, seja nos corpos. Novamente, acusações, hostilidades, falsidade se o desejo de ser "natural" convivem no imaginário e nas relações entre travestis e mulheres, segundo Kulick: “[...] as idéias sobre travestis e mulheres também se manifestam em uma relação tensa, problemática e antagônica, uma relação em que as travestis são o reflexo, mas as mulheres são o espelho." (: 211 214).

Prossegue o autor: "[...] a subjetividade travesti é o resultado - e ao mesmo tempo a incorporação e a efetuação - de uma certa configuração de sexo (biológico), gênero e sexualidade, configuração que é específica da sociedade na qual as travestis vivem". O universo social de atuação das travestis é composto por três tipos distintos de pessoas "generizadas": homens, mulheres e "viados" (travestis ou homossexuais). Nessa "tripartição de gênero" as travestis atuam e encarnam esse sistema, não como um "terceiro sexo", mas jogando com a binariedade, fluindo as vezes na oposição, as vezes identificação, o que o autor chama de "o gênero travesti”. (: 235). 
Interessante mencionar que para os órgãos nacionais e internacionais de classificação de doenças, "transexuais" e travestis são as únicas identidades político-sociais representadas pelo movimento LGBTTT mantidas como enfermidade $^{125}$. As demais "letras-pessoas" foram "libertadas" dos compêndios médicos.

Para finalizar, essa dissertação não pretende negar as estruturas reiteradas de poder contidas nas concepções e naturalizações/essencializações do que venha a ser "a mulher" e "o homem" nas sociedades contemporâneas, tão pouco desconsiderar construções fundamentais que pesquisadoras e autoras feministas, movimentos e grupos de mulheres trouxeram à compreensão das questões de gênero. O que se reflete neste capítulo são as exageradas expectativas fetichistas, exotizantes, sobre sujeitas que, de acordo com as pesquisadoras acima entre outras, reforçariam também estereótipos. Nessa leitura etnocêntrica, as sujeitas são meros "objetos" a "serviço do patriarcado", merecedoras de descrédito como no chavão: - "Coitadas! Elas não sabem do que estão falando! Ao invés de subverter, revolucionar, preferem serem mulheres normais!"

\section{Estigma, ausência de reconhecimento e identidade: violência moral.}

\subsection{0 estigma.}

A ideia de estigma na proposição de Erving Goffman(2004) no trabalho "Estigma: notas sobre a manipulação da identidade deteriorada" se refere a: "um tipo especial de relação entre atributo e estereótipo [...] em parte porque há importantes atributos que em quase toda a nossa sociedade levam ao descrédito"(: 7). Adverte o autor que não se trata do atributo em si, mas de "uma linguagem de relações e atributos". Assim, o atributo mencionado é aquele "profundamente depreciativo" que num mesmo movimento estigmatiza alguém confirmando a normalidade de outrem. Para Goffman, isoladamente, o atributo não é honroso ou desonroso (: 6).

\footnotetext{
${ }^{125}$ Atualmente no CID10, ambas as categorias estão alocadas no F64 ("Transtornos de Identidade de Gênero"), sendo que, como visto no começo do trabalho, F64.0 é "Transexualismo" e F64.1 representa o "Travestismo Bivalente".
} 
Informa-nos que a sociedade categoriza pessoas, atribuindo-lhes características consideradas comuns e naturais para cada um de seus membros. Os ambientes sociais preconizam as categorias de indivíduos prováveis naqueles espaços. As rotinas de interrelação social permitem contato com "outras pessoas" sem atenção particular por serem de mesma categoria. Quando se tem contato com um estranho antecipa-se imediatamente, por intermédio de sua categoria e de seus atributos, sua "identidade social". Essas preconcepções são transformadas em expectativas normativas, exigências rigorosas. A essa operação prévia Goffmam chama de "identidade social virtual". Aquelas que o indivíduo comprova possuir formam sua "identidade social real". Surgindo evidências que o diferenciariam, num caso extremo, tornando-o indesejável, deixa-se de considerá-lo como indivíduo comum e total, reduz-se então a pessoa a qualidade de "estragada e diminuída". É o que nomeia por estigma: um defeito, uma fraqueza, uma desvantagem, "discrepância específica entre a identidade social virtual e a identidade social real".(:5-6).

Identifica três tipos de estigma: as abominações do corpo (chama de "deformidades físicas"); as "culpas de caráter individual" que guardariam relação com pendores, desejos, moralidades específicas, "inferidas a partir de relatos" (exemplos: "distúrbio mental, prisão, vício, alcoolismo, homossexualismo, desemprego, tentativas de suicídio e comportamento político radical"); e os sinais tribais de raça, nação, religião(o autor ainda acrescenta a "classe social"), transmissíveis através da linhagem, afetando indistintamente todos os familiares. Em todos os casos, os atributos estigmatizados chamariam a atenção de tal modo que afastaria a companhia dos demais normais ${ }^{126}$ (o autor se inclui na categoria dos normais) e assim "destruindo a possibilidade de atenção para outros atributos seus." (:7). Na crença da desumanidade do estigmatizado, atos de discriminações são comuns. Constroem-se teorias e ideologias explicativas da inferioridade, advertindose para os perigos de sua proximidade. Termos como: "aleijado", "bastardo", "retardado" são utilizados sem que se reflita nos significados originais. (:8).

\footnotetext{
${ }^{126}$ Quase ao fim da obra o autor delimita as características do indivíduo qualificado como "normal": "[...] Num sentido importante há só um tipo de homem que não tem nada do que se envergonhar: um homem jovem, casado, pai de família, branco, urbano, do Norte, heterossexual, protestante, de educação universitária, bem empregado, de bom aspecto, bom peso, boa altura e com um sucesso recente nos esportes". (: 109).
} 
Do lado do estigmatizado, afirma o autor, quando se é possível corrigir diretamente o defeito: "[...] o que freqüentemente ocorre não é a aquisição de um status completamente normal, mas uma transformação do ego: alguém que tinha um defeito particular se transforma em alguém que tem provas de tê-lo corrigido." Nesses casos, os estigmatizados mostram-se dispostos a seguir tratamentos ou procedimentos extremos em razão das angústias do defeito. Por vezes, o estigmatizado depois de corrigida "a desvantagem" percebe que os normais também têm problemas. Uma vez livres do defeito, podem desenvolver outros de caráter psíquico (: 11-13).

Nas interações entre normais e estigmatizados, quando o defeito é percebido no primeiro olhar, ou mesmo antes desse contato, se está diante de uma pessoa desacreditada cujo contato com normais sempre provoca tensões (: 17; 38). Quando o normal não percebe o estigma, o estigmatizado poderá, segundo o autor, efetuar a "manipulação de informação sobre o seu defeito. Exibi-lo ou ocultá-lo; conta-lo ou não contá-lo; revelá-lo ou escondê-lo; mentir ou não mentir; e, em cada caso, para quem, como, quando e onde". Nessa situação, será uma pessoa desacreditável aquela que manipula e/ou esconde informações sobre sua "identidade social verdadeira" (: 38-39). Nessa última categoria o autor elenca como exemplos os criminosos (: 62), as prostitutas, os homossexuais, mendigos e viciados em droga, além das vagabundas (: 65$)$. Em todos os casos, a manipulação se dá em razão das "normas de identidade" (: 111) e em relação a essas os indivíduos figuram como "desviantes sociais" (: 121).

Mas que espécies de indivíduos partilhariam relações com o estigmatizado? O autor afirma que são de dois tipos: as pessoas benevolentes (os normais) e aquelas com o mesmo estigma (entre iguais). Nos últimos, pode-se esperar algum apoio quando se definem ou são definidos como iguais. Já os normais "cuja situação especial levou a privar intimamente da vida secreta do indivíduo estigmatizado", são chamados por Goffman de "informados"127. Esses tratam os estigmatizados como "uma pessoa comum". Há também entre os "informados" aqueles que se relacionam com o estigmatizado "através da estrutura

\footnotetext{
${ }^{127}$ Goffman explica que pegou emprestado "um termo utilizado por homossexuais" (: 27$)$. Em português poderia se traduzira título de comparação essa palavra por "simpatizante", já decaida da sigla representativa do movimento LGBTTT, quando ainda eram conhecidos como "GLS". O "S" final seria para representar os simpatizantes.
} 
social" e que a sociedade considera a ambos "como uma só pessoa". Nesse último caso, cita como exemplos: "a mulher fiel do paciente mental, a filha do ex-presidiário, o pai do aleijado, o amigo do cego, a família do carrasco", repartindo com o estigmatizado parte do descrédito social a ele dirigido (: 20-28).

Para concluir, o estigma é concepção simbológica radical imputada a determinados indivíduos para marcá-los a fim de se evitar que "normais" tenham contato com o "não-normal". Como visto em Goffman, a categorização dos atributos depreciativos qualificando o sujeito se processa de forma independente da maneira como aquele se vê e, quando negativos, são estigmas. Importante salientar que as categorias descritas pelo autor foram forjadas a partir de um momento histórico preciso e um lugar próprio. Evidentemente, muitas delas nem são mais vistas como estigma, nos termos propostos pelo autor. Entretanto, são úteis para se entender as atuais práticas médico-psicológicas e jurídicas que situa sujeitas e sujeitos no olhar do estigma; seja na categoria "transexual" (estigma de doença ou comportamento desviante), seja na presença de um pênis em alguém que se identifique como mulher (estigma de defeito físico) marcam negativamente a/o indivídua/o. Esse último "defeito" é particularmente revelador numa tentativa de compreensão do problema visto pela sujeita.

\section{2 $O$ olhar interno e as questões de identidade.}

A partir de uma escuta que se propõe priorizar o discurso da sujeita sobre ela mesma, o que se nomeia como transexualidade é categoria exógena, "fechada", de exclusão ou eliminação, estigmatizada, cuja percepção do grau de importância daqueles que a acionam dependerá dos interesses em jogo: acionada pelos "especialistas", médicos, psiquiatras, psicólogos, juristas entre outros, tem principalmente as funções de: separar "transexuais verdadeiros" autorizando ou não as cirurgias e/ou alterações documentais; excluir indivíduos "não-transexuais"; e garantir que as cirurgias e as modificações documentais sejam permanentes, sem arrependimentos futuros. Todos esses pontos foram debatidos nas primeiras partes deste capítulo. Entretanto, quando são as sujeitas e os sujeitos que lançam mão dessa terminologia, via de regra, desejam: obter as cirurgias modificadoras; os êxitos 
nas demandas judiciais; e o reconhecimento ou acolhimento da identidade feminina ou de mulher e masculina ou de homem.

Explica-nos Luís Roberto Cardoso de Oliveira (2007) acerca da fusão de horizontes no artigo "O ofício do antropólogo ou como desvendar evidências simbólicas" que a Antropologia é um campo de saber que busca tradicionalmente articular o olhar de fora com o olhar de dentro (tradição francesa) ou privilegiar o ponto de vista do nativo (mundo anglo-saxão) ou ainda considerar seriamente o ponto de vista do ator (concepção weberiana). Em comum com a Sociologia, partilharia o interesse na organização social, estruturas e práticas vigentes, enfatizando o "ponto de vista interno, do nativo, ou do ator" (: 7). Assim, grosso modo, a fusão de horizontes se estabelece quando a antropóloga consegue conectar suas preconcepções com aquela trazida pelo grupo ou sujeitas estudadas, provendo de sentidos o que se observa (:8).

$\mathrm{Na}$ interpretação antropológica, Cardoso de Oliveira chama a atenção para o tensionamento entre as duas dimensões do pensamento contra-intuitivo: a material e a simbólica - as formas de apreensão do conhecimento a partir da percepção da pesquisadora. O intuitivo pode ser descrito como o senso comum ou não especializado em determinado tema. O contra-intuitivo representaria a experiência empírica. As evidências materiais são aquelas racionalmente comprováveis $^{128}$ e as simbólicas, embora não materiais são igualmente empíricas e tão concretas quanto aquelas. De acordo com o autor, "o ofício do antropólogo teria como principal característica a capacidade de desvendar ou de interpretar evidências simbólicas", acessíveis por intermédio de representações, visões de mundo ou da ideologia(nos termos de Louis Dumont) da sociedade que se estuda. (: 10). Assim, a dimensão simbólica da vida social se torna fundamental para a interpretação etnográfica (: 13).

\footnotetext{
${ }^{128} \mathrm{O}$ autor explana melhor a diferenciação entre o pensamento intuitivo e o contra-intuitivo material ilustrando com o experimento cientifico de Galileu ao arremessar diversos objetos com pesos e massas diferentes do alto da Torre de Pisa, caindo todos no solo ao mesmo tempo, contrariando as expectativas à época de que o objeto mais pesado chegaria ao chão primeiro.
} 


\subsection{Conhecimento e (ausência de) reconhecimento.- "Já entendi. Você é uma transexual!" - “Não! Você não entendeu! Eu disse que sou mulher!”}

Como se verá nos próximos capítulos, as interlocutoras desse trabalho afirmam serem mulheres, independentemente de haverem realizado as cirurgias ou alterado o prenome. Quando em situações pontuais tiveram de classificar-se como "transexual" o fizeram cientes de que esse era o único caminho que levaria ao êxito dos pleitos. Assim, o problema para as sujeitas situa-se em "quando e onde devo utilizar a categoria 'transexual' para o sucesso daquilo que desejo?" E "em que medida utilizar essa categoria ofende minha dignidade ou insulta-me moralmente?" Essas questões se pretende responder na parte etnográfica do trabalho. Neste capítulo analisaremos os atos de conhecimento e reconhecimento.

$\mathrm{Na}$ busca por referências sobre a "epistemologia do reconhecimento", Axel Honneth em "Invisibility: on the epistemlogy of 'recognition"'(2001)nos reporta as diferenças entre os significados de "invisibilidade" literal e figurativa (ou "em sentido metafórico"). Afirma que determinadas pessoas não são vistas num determinado sistema de status sociais, estando-se assim no campo da "nãoexistência em sentido social" (: 111). As pessoas "invisibilizadas" sentem-se não "percebidas", porém essa ausência de percepção significa mais do que não ter sido vista, é não ter sido identificada ou conhecida (:113).A esse ponto, o autor chama atenção para a passagem da "invisibilidade" figurativa à visibilidade literal. Para ser "invisível", necessário que seja conhecido ou identificado previamente numa ordem tempo-espaço que fixa cada qual em determinada posição hierárquica. Aos que não pertençam à categoria "nós" serão enxergados "através" ("looking through"), como se não estivessem no ambiente, invisíveis socialmente (: 114).

Honneth então passa a diferenciar "conhecimento" (cognizing Erkennem) e "reconhecimento" (recognizing - Anerkennem). Por "conhecer" significa identificar uma pessoa individualizando-a no que chama de "ato cognitivonãopublico". Já "reconhecer" se refere ao ato expressivo, público e recíproco cujo conhecimento é confirmado de forma afirmativa (aprovação ou validade social) através de ações, gestos ou expressões faciais (: 115-116). No reconhecimento, as posições/papeis devem ser condizentes com a escala de valor a qual o indivíduo 
pertença. A ausência da performance é normalmente representada pela condição de "invisibilidade". Os atos corporais ou gestuais presentes no reconhecimento constituem igualmente uma das diferenças em relação a conhecer. Nesse caso, a ostensividade é voltada ao reconhecimento da autoridade moral do interlocutor de forma mútua (: 120-126). Tais formas de expressão sofrem variações consideráveis entre diferentes culturas, mas a função de comunicação social estará sempre presente(: 119).

De acordo com Honneth, três são dimensões do reconhecimento: o amor, o respeito e a solidariedade. Então, ao repertório de gestual expressivo quando há a "inteligibilidade" do outro como um ser amado, ou digno/merecido de respeito ou de solidariedade, adiciona-se essa inteligibilidade real representativa da percepção sobre o valor moral que se deve considerar reciprocamente. Assim, a invisibilidade social sempre ocorreria com o desrespeito a uma das dimensões do reconhecimento (: 122-123).

Ainda sobre reconhecimento, Charles Taylor (1992), em "El multiculturalismo y "la política del reconocimiento", apresenta-nos um panorama social e político de grupos identitários no multiculturalismo. Para ele, o falso reconhecimento ou a falta de reconhecimento pode gerar danos, "aprisionando alguém em um modo de ser falso, deformado e reduzido" causando as suas vítimas um ódio mutilador a si mesmas (: 44-45). Taylor afirma que as pessoas se formam pela linguagem (sentido amplo) em processos dialógicos e relacionais. Nesse sentido, a identidade se formaria pelas negociações intermediadas dos diálogos externo e interno com as demais pessoas. Para a formulação do "quem somos" e "de onde viemos", a identidade depende de forma crucial das relações dialógicas com os demais (os "outros significantes") (: 55).

Assim, o discurso do reconhecimento tem dois níveis: na esfera íntima (formação da identidade e do eu em diálogo com os outros significantes) e na esfera pública (lugar da política de reconhecimento igualitário). O autor investiga a esfera pública para compreensão sobre a "cidadania igualitária" como um princípio universalmente aceito e da "política da diferença" que faz com que cada um seja 
reconhecido por sua identidade única. Para ele, "a demanda universal impele a um reconhecimento da especificidade" (: 62).

A dignidade então deve preconizar o respeito absoluto ainda que em potencial. A política de diferença guarda o potencial de moldar e definir a própria identidade como indivíduos e como cultura. Assim, tratar as pessoas de uma forma "cega à diferença", já que todos são iguais (igualdade), bem como reconhecer e fomentar a particularidade (diferença) estão intimamente ligados: para o autor os primeiros, supostamente neutros, na verdade são o reflexo de uma cultura hegemônica. Consequentemente, a sociedade que se pretende justa e cega às diferenças, não apenas é inumana (na medida em que não considera as identidades), mas também discriminatória (sutil e inconsciente) (:65-67).

Finalmente, o autor se posiciona a favor de um modelo de sociedade em que se inclua mais de uma comunidade cultural, reconhecendo-se valor igual às diferentes culturas e não apenas meras formas de sobrevivências dentro das sociedades multiculturais (: 94-95). Adverte, então, para os atos de respeito simulado, pois nesses há a depreciação à inteligência de quem os recebe. E o que se busca é o reconhecimento e o respeito, mas com autenticidade em ambos. Salientando que há graves problemas na política do multiculturalismo, destaca entre eles a homogeneização, pois as referências antecedentes (os cânones) são da cultura dominante e assim os juízos de valor são, implicitamente, os mesmos, quando não etnocêntricos. Necessário se encontrar um ponto de equilíbrio entre a inautenticidade e o etnocentrismo (: 103-106).

\subsection{Insulto moral.}

Seja explicitamente, seja subentendido, todas as quatro interlocutoras desejam ser reconhecidas como mulheres, já que é assim que se veem, sentem-se, situam-se no mundo. Em diversas situações, as sujeitas tiveram sua identidade sistematicamente negada ou desconsiderada nos ambientes médico-psicológicos, jurídicos, dentre outros campos sociais. 
Nas demandas por direitos que de alguma maneira envolvam o reconhecimento da identidade, Luís Roberto Cardoso de Oliveira (2004),em "Honra, Dignidade e Reciprocidade", alerta para as dificuldades na formulação de um discurso institucional e diferenciador que legitime direitos não universais contemplando grupos específicos em razão das características presentes em suas identidades. Enfatiza também as dificuldades em tornar visíveis o insulto ou ato de desconsideração em razão da falta do reconhecimento como "uma agressão objetiva, merecedora de reparação". Assim, não há nem instrumentos institucionalizados que caracterizem corretamente "a percepção de desonra ou indignação experimentada pelo ator que vê sua identidade, negada, diminuída ou insultada", tão pouco mecanismos para a reparação ou reestruturação da integridade moral dos sujeitos(:2).

Para o autor, ao expressar emocionalmente sua indignação frente a uma experiência do insulto, os atores estão demonstrando que:

A relação entre dignidade, identidade e sentimentos indica a importância da alteridade ou do caráter dialógico do reconhecimento, que não pode ser expresso adequadamente no plano exclusivamente formal, exigindo de alter e ego trocas substantivas de palavras ou gestos (símbolos em geral) que representem, aos olhos de ambos, manifestações mútuas de consideração e apreço. (: 2-3).

Nesses casos, o reconhecimento implica necessariamente manifestar claramente a aprovação, mas essa manifestação não poderá ser meramente legal ou impositiva, pois se está diante da "dimensão moral dos conflitos ${ }^{129 "}$. Quem demanda quer que o valor ou mérito de sua maneira de ser seja visto positivamente, de modo a identificar a substância moral de sua dignidade. E para a satisfação plena das emoções dos envolvidos, o apreço e a consideração devem ser recíproca e espontaneamente expressados.

$\mathrm{Na}$ ausência do reconhecimento seja de forma imperceptível, seja por claros atos de desconsideração, a consequência será a "negação do status ou a rejeição da identidade do interlocutor", percebida como indiferença ou agressão, o que caracterizarão insulto moral. (:4-5).

\footnotetext{
${ }^{129}$ Nesse ensaio assim como alguns outros trabalhos, Luís Roberto Cardoso de Oliveira discute o que chama de "problemática da dádiva" e seu campo interpretativo em debate com diversos autores. Ver também "Direito legal e insulto moral: dilemas da cidadania no Brasil, Quebec e EUA." (2011).
} 
Em "Existe violência sem agressão moral?", Luís Roberto Cardoso de Oliveira (2008), ressalta as duas principais características do insulto moral:

(1) Trata-se de uma agressão objetiva a direitos que não pode ser adequadamente traduzida em evidências materiais; e, (2) sempre implica uma desvalorização ou negação da identidade do outro (: 136).

Ao retomar os debates sobre dádiva e reciprocidade, dimensão moral dos conflitos, expressão de emoção e evocação dos sentimentos, entre outros, o autor traz novamente a problemática do reconhecimento da identidade, resumindo:

Nos casos em que o reconhecimento torna-se uma questão, a ausência deste sinal é vivida como uma negação da identidade do interlocutor, que se sente agredido. É nesse sentido, que o aspecto dialógico do reconhecimento se faz presente com todas as suas implicações. Isto também significa que o reconhecimento é uma atitude ou um direito que precisa ser permanentemente cultivado, e que as demandas a ele associadas não podem jamais ser contempladas de forma definitiva. Mesmo quando elas são plenamente satisfeitas em um determinado momento, não há garantia de que o problema não possa reaparecer no futuro (: 138).

Quanto à dimensão temática do reconhecimento na administração de conflitos judiciais, o autor observa que essa é frequentemente deixada de lado pelo Poder Judiciário, o que "além de inviabilizar a compreensão das causas" poderia colaborar eventualmente com o agravamento dos conflitos, como nos exemplos de "desvalorização da identidade da vítima", nas ações de agressões contra mulheres processadas pelos Juizados Especiais Criminais (Jecrims) antes da Lei Maria da Penha $^{130}$ onde a condenação dos agressores cingia-se em pagamento de cestas básicas(idem).

Com os autores acima e a partir das falas das interlocutoras como se verá logo adiante, pode-se afirmar que em alguma medida a negativa expressa ou tácita da demanda por reconhecimento, bem como os atos de desconsideração das identidades das sujeitas promovidos pelo Estado-Juiz ou agentes e instituições cuja supremacia de decisão situa-se acima das cidadãs, tais como o saber-poder médicopsicológico, produzem(e reproduzem) agressões de natureza moral. Ao que parece

\footnotetext{
${ }^{130}$ Sobre esse tema, ver artigo de Guita Grin Debert e Marcela Beraldo de Oliveira "Os modelos conciliatórios de solução de conflitos e a "violência doméstica"' (2007), uma etnografia realizada antes da implementação da Lei Maria da Penha.
} 
tanto o poder-saber médico-psicológico quanto o Poder Judiciário insistem em enxergar as sujeitas como portadoras de espécie de estigma, como proposto por Goffman. Porém, para elas, o atributo físico estigmatizado, em si, não é "honroso ou desonroso", tanto que se é possível identificar-se como mulher independentemente de se realizar ou não as cirurgias.

Portanto, conjuntamente aos pleitos de adequação da genitália e alteração de prenome e gênero - plenamente exigíveis do ponto de vista jurídico ou legal - as sujeitas demandam o reconhecimento da identidade, que como visto em Honneth, é diferente do ato de "conhecimento". A visibilidade para elas só se dará unicamente na categoria de mulheres, pois quaisquer tentativas de "aditivar", "qualificar", "negritar" ou "sublinhar", não servirá ao reconhecimento pretendido. O mesmo se dá com a identidade individual diante da igualdade universal, como proposto por Taylor. Os direitos não podem se dar apenas no plano formal e "cego às diferenças", porque igualmente se cometerá violações.

A dignidade ofendida como em Cardoso de Oliveira não significa apenas não reconhecer que se têm direitos radicalmente universais, mas também que a sujeita é reconhecida como pessoa digna, de valor, merecedora de apreço pelo que ela é em si, independentemente de critérios de desempenho. Segundo Luís Roberto Cardoso de Oliveira, quem demanda reconhecimento não admite ser avaliado por critérios externos, mas acredita poder demonstrar objetivamente o valor de sua maneira de ser ou daquilo que quer ver reconhecido. ${ }^{131} \mathrm{Na}$ dimensão dialógica, a sujeita demanda o reconhecimento com atos de manifestação espontâneos e não por mera obrigação legal. Em caso de desconsideração ou negação da identidade, se está diante de possível violência moral, porém, dadas as dificuldades em se tornar visíveis, os atos de violência não podem ser adequadamente traduzidos em evidencias materiais.

Recomenda-se assim a escuta atenta e o equacionamento adequado dos pedidos por parte dos "especialistas" no que concerne às identidades das postulantes, pois além da demanda pela autorização das cirurgias e alteração documental, há também outra igualmente fundamental em que se exige o

\footnotetext{
${ }^{131}$ Ver em: "O material, o simbólico e o contra-intuitivo: uma trajetória reflexiva", Série Antropologia Vol. 421, Brasília: DAN/UnB, 2008, p. 24-25.
} 
reconhecimento da identidade feminina ou de mulher. Com zelo e cuidado, todos esses pleitos podem perfeitamente ser comtemplados sem maiores esforços dos atores institucionais e sociais.

Caso contrário haverá sempre dissintonias do tipo:

- "Requeiro a cirurgia de adequação genital e as alterações documentais para viver plena e dignamente a mulher que sou!"

- "Já entendi. Você é uma transexual!"

- "Não! Você não entendeu! Eu disse que sou mulher! As cirurgias e modificações documentais são para a satisfação íntima e o reconhecimento da minha identidade de mulher em todos os espaços sociais! 
Capítulo 2 - Bruxa Malvada do Oeste.

"Todas somos mulheres de contextos... Somos mulheres de contexto".

Para mim ser mulher é viver a sua individualidade, suas subjetividades, suas peculiaridades. Vivenciar isso de uma forma sua, sabe? Uma forma sua que você vai criando no seu dia a dia. Assim como talvez possa ser [com um] homem, também. Acho que não tem uma fórmula, o que é uma mulher... Primeiro de tudo, o que é um ser humano? A mulher é um ser humano! $E$ o que é ser mulher na minha concepção, que não é a concepção muito usual. Fala-se uma coisa e na prática é outra. A mulher é ser humano igual ao homem. Que constrói cada dia. Ganha-se muita coisa. Luta-se muito. Nessa conquista houve perdas, nessa trajetória houve perdas. A mulher que eu sou é a mulher que eu não vejo escrita ainda. Não leio sobre ela. Não vejo escrita, não vejo retratada, não vejo.... Então, fica difícil encontrar esse ser mulher que sou eu. Vamos criar isso! Talvez, no futuro alguém saberá dizer o que eu estou querendo dizer agora.

As palavras acima são da Bruxa Malvada do Oeste, estudante de psicologia de 39 anos, moradora da região norte do País. Pensamos juntas numa forma de escrita que não a expusesse tanto, pois além de morar numa cidade relativamente pequena onde todos se conhecem, ela já não tem mais interesse ou necessidade em abordar esse tema. Conhecemo-nos no ano de 2007, num evento sobre saúde da mulher no Ministério da Saúde, em Brasília/DF. Ambas éramos militantes dos movimentos de mulheres. Nossa amizade, embora tenhamos nos visto pessoalmente em poucas ocasiões, sempre foi profunda. Nunca deixamos de 
manter contato, por e-mails, mensagens, telefonemas. Nossos assuntos e o grau de intimidade são como os de amigas de muitos anos.

Já naquela época, conversávamos sobre os problemas da atribuição de identidade naquilo que se nomeia por "transexualidade" no imaginário popular mesmo quando a sujeita não se identifica com o termo ou aquela identidade. Perguntei-Ihe, então, se não desejaria contribuir para a elucidação dessas questões.

Para a entrevista, passei três dias como convidada dela e de sua mãe em julho de 2014 na aconchegante casa. As perguntas iniciais foram partilhadas com antecedência e modificadas durante as interlocuções. Na verdade, elas pouco importaram, pois a relação de amizade e carinho propiciou trocas de maneira espontânea, necessitando de muito pouco direcionamento.

Borramos partes da trajetória porque não queríamos expô-la, nem correr o risco de "biografar" -como dito anteriormente - sintetizando equivocadamente uma vida inteira, riquíssima, em algumas páginas. Inicialmente, sugeri que escrevêssemos juntas o capítulo. Como ela teve aprovado um plano de trabalho de iniciação científica, tornando inviável o ir e vir de escritas, optei por começar e ela revisar e finalizar, caso fosse necessário, a escrita das cenas ${ }^{132}$. Lembrando as palavras do Coletivo Sangtin: "só se pode escrever sobre sua própria "Yatra" (jornada)".Então, essa reescrita era ponto de honra para mim. A própria sujeita, desnudando-se à minha compreensão numa sociedade que não a entende e não quer compreender, foi como encontrar um tesouro!

Trata-se de uma tentativa de reflexão a quatro mãos. Para Nagar, É preciso "Verdade e transparência na reflexão coletiva" (2006: 9). A economia textual não pode mutilar o texto. Então: "O que escrever? E o que deixar não-escrito?" (idem) Cientes das dificuldades, transpusemos muitas histórias, contos, ideias. Porém, grande parte dos dados se perde. Seja durante a conversa, seja na formatação escrita. Não escrevemos muita coisa. Quanto de vida cabe num ensaio?

\footnotetext{
${ }^{132}$ Destaco, para eventuais preocupações metodológicas, que as modificações realizadas pela interlocutora não afetaram a condução autoral, nem impediram a interpretação teórica e crítica, nos moldes que a antropologia demanda. Foram apenas dados pessoais, nomes, referências e lugares modificados ou omitidos para a proteção da sujeita.
} 
Depuramos o conteúdo em algumas cenas na tentativa de explorar os detalhes, reconhecendo mesmo assim que muita coisa fica na memória ou vira "salto".

Como dito no capítulo primeiro, escolhemos nomear as protagonistas dessas trajetórias com codinomes de bruxas de fábulas infantis. Naquelas narrativas as antagonistas são (re)contadas por aqueles que se consideram "bons", "corretos", "heróis", sempre de forma a parecer que as sujeitas são "más", "perversas", "cruéis". As interlocutoras deste trabalho também tiveram (e ainda têm) a história contada por terceiros. Elas foram e são conhecidas como "diferentes", "não-normais", "farsantes"; em alguns casos, até "maléficas". Quase nunca têm oportunidade de falar de si, com sua própria sabedoria.

As fábulas são narrativas coletivas, imemorais e reapropriadas infinitamente. Muitas são de tradição oral e discorrem sobre mitos, heróis, deuses, com pretensões de trazer lições de vida. A personagem "Bruxa Malvada do Oeste" foi condensada no século passado pelo escritor Lyman Frank Baum ${ }^{133}$, na história "O maravilhoso mágico de $\mathrm{Oz}$ ", possivelmente personificando diversos fragmentos das lendas de antiquíssimas narrativas sobre bruxas. Na versão adaptada ao cinema ${ }^{134}$, Bruxa Má do Oeste é a governante do país Winkie, na Terra de Oz, onde os habitantes Winkies são seus escravos. Sua irmã, Bruxa Malvada do Leste, fora morta e ela acredita ter sido pelas mãos da protagonista Dorothy. Para vingar a irmã, persegue a protagonista da história até ser morta pela heroína e seus amigos: Espantalho, Homem de Lata, Leão Medroso e o cãozinho Totó.

Assim, sugeri o nome dessa personagem. A interlocutora prontamente assentiu, pois gosta muito dessa fábula.

Em comum com as bruxas, há também os rituais. Bruxa Malvada do Oeste realizou um dos mais importantes na noite anterior à da cirurgia, mantendo a fé em si, nas suas próprias conviç̧ões, para trilhar ou mudar caminhos. Uma das origens linguísticas do vocábulo "bruxa" é na tradição de Portugal e Galiza, "mulher

\footnotetext{
133 Informações extraídas do sítio: http://pt.wikipedia.org/wiki/L. Frank Baum. Último acesso em: 01/05/15.

${ }^{134}$ Disponível em:

http://pt.wikipedia.org/wiki/The_Wizard_of_Oz_\%281939\%29

Ultimo acesso em 01/05/15.
} 
sábia $^{135 " . ~ N o ~ l a t i m, ~ " a q u e l a ~ q u e ~ s a b e ~ m a i s, ~ q u e ~ t e m ~ m a i s ~ c o n h e c i m e n t o " . ~ E m b o r a ~}$ nesse momento não seja uma praticante da chamada "Arte Antiga", a interlocutora mesmo escolheu essa denominação. E se verá que tal como as Bruxas as interlocutoras deste trabalho são muito sábias.

Bruxa Malvada do Oeste é mulher autodeclarada desde que se entende por gente. Quando criança ela e a irmã tiveram de amadurecer rapidamente em razão de percursos duríssimos, de abandono, fome e miséria. $\mathrm{Na}$ adolescência enfrentou problemas próprios da idade, mas um específico tomava sua atenção: a presença de um pênis entre as pernas e o sentimento de pertencimento à identidade feminina tida como oposta àquela insistentemente submetida nos espaços sociais. $A$ ausência das informações sobre o problema instigava a curiosidade ("as informações não chegavam. E quando chegavam, chegavam deturpadas.'). Fundamental para ela era a diferenciação em relação às travestis. A história da modelo carioca Roberta Gambine Moreira, conhecida nacionalmente como Roberta Close ${ }^{136}$, serviu como orientação, mostrando que era possível ao menos "corrigir", o "dedo a mais", o "lábio leporino", a anomalia, como acreditava ser sua a genitália.

$\mathrm{Na}$ escola foi uma guerra por dia. Ela se recusava a usar uniformes masculinos quando diferenciados dos femininos. Um dia, a diretora do colégio advertiu-a que deferia vir "uniformizado", com os cabelos amarrados, caso contrário não mais seria aceita na instituição. Entristecida, foi buscar seus direitos para tentar solucionar o problema. Acionou sua chefa, uma advogada, no estágio como menor aprendiz. $\mathrm{O}$ ato descuidado da advogada provocou a curiosidade (e a maldade!) de toda a cidade. Saiu em todos os jornais, com fotos e detalhes ("foi uma guerra. Um circo. Foi horrível!"). "A travesti normalista", como alardearam as manchetes da época, acabou por destruir o sonho de lecionar e tornou a vida um inferno.

\footnotetext{
${ }^{135}$ O Bruxo Tradicional Ibérico e estudioso sobre o tema, Everson Romero, cita o historiador espanhol especialista em Bruxaria, Julio Caro Baroja (Professor de História da Universidad de Madrid) para corroborar com as tradições portuguesas e galizas a origem latina para "Bruxa" no termo "Plusscios" (junção de "Plus" \{mais\} com "Scios" \{ciência\}) Para Romero, "É, portanto, Plusscios "Aquele que sabe mais, que tem mais conhecimento'. Ou seja, Bruxa/Bruxo significa Sábia/Sábio, e Bruxaria, significa Sabedoria". Obviamente que há muitas outras teses sobre as origens e significados, mas estes servem bem à compreensão da sujeitas como propomos aqui.

${ }^{136} \mathrm{Em} 1998$ a Editora Record lançou a biografia "Muito prazer, Roberta Close", escrita por Lúcia Rito. Embora muito conhecida, seu livro não está mais disponível para compra.
} 
Ela me barrou na entrada. Eu fazia estágio em um programa para menor aprendiz. Estava trabalhando com advogados, daí a minha chefa me viu chateada, triste. Eu contei tudo. Ela disse: - "mas isso não pode! Você tem direito à educação!" E disse um monte de outras coisas sobre a Constituição e tal. A secretária de educação a pedido da advogada fez um memorando e me deu. Eu fui cheia da razão. Foi uma guerra! Saiu em todos os jornais, a expulsão. O grêmio estudantil querendo que eu ficasse, a direção que eu saísse. Foi um circo, um circo, um circo!

Após terminar os estudos secundários, nunca pôde exercer o magistério:

Eu fui impedida de exercer a profissão justamente por não ter um rótulo para me encaixar: eu não era travesti, não era gay e para eles não era mulher. Então, não tinha onde me encaixar. Não havia possibilidades! [...] Então, o direito não tinha portas. Porque a documentação me negava o direito feminino, minha identidade feminina. A minha identidade social chocava quando tinham acesso aos documentos. Não tive problemas com os alunos, mas nas questões administrativas, os gestores tinham problemas de como me encaixar. Os estágios foram difíceis de conseguir. Depois, eu me intimidei e não procurei emprego.

Sem possibilidades de um emprego que a agradasse, encontrou nos salões de beleza a única possibilidade de ter um trabalho formal. Sempre às voltas com aliciadores para a prostituição, resistiu a exercer tal oficio, até que aos 26 anos, desacreditada de conseguir realizar a cirurgia através das experiências que estavam sendo feitas nas universidades de medicina, aceitou prostituir-se na ltália. E esse foi o caminho da contingência. Bruxa Malvada do Oeste temia a função por várias razões ("Convivi todo dia com o perigo."). Porém, ela tinha objetivos certos: juntar dinheiro para custear a cirurgia e ajudar a mãe na reforma da casa. Temendo morrer durante $\mathrm{o}$ ato cirúrgico, inverteu a ordem de prioridades, enviando primeiramente à mãe o dinheiro necessário as reformas da casa.

Em 2005, já adulta e independente, conseguiu realizar com sucesso a cirurgia de adequação da genitália:

Foi um segundo parto que você mesma faz [para] nascer de novo!

Por indicação de amigos, realizou-a na Tailândia numa das mais (mundialmente) conhecidas clínicas para essas intervenções ${ }^{137}$. Como não falava inglês, a psiquiatra que a avaliou na Itália onde morava, sensibilizada com a história da interlocutora, pediu a um amigo médico que a acompanhasse ao país asiático.

\footnotetext{
${ }^{137}$ Preecha Aesthetic Institute - PAI. Ver em: http://pai.co.th/category/gender-reassignment/ Última visita em: 01/05/15.
} 
Há algumas centenas de clínicas naquele país, tornando-o conhecido como referência no assunto. Graças ao que se poderia chamar de "lei da procura e oferta", ela pôde escolher absolutamente tudo. Desde padrões estéticos na intervenção ("Na Tailândia eles fazem um portfólio de vários modelos.") até a alimentação, passando por recuperação em apartamento individual e massagens nos pés para relaxar ${ }^{138}$.

Uma semana depois:

Aí, no espelho do banheiro, um espelho inteiro, eu levantei a roupa e chorei. Minha "xaninha"! Tão linda, tão linda, que bom é verdade! Agora eu tenho realmente. Uma coisa harmoniosa. Parecia que eu sempre fui daquele jeito e chorei e liguei para a mãe.

Como todo mundo, ela também tinha enormes expectativas. Nos primeiros dias após a alta hospitalar se viu a sós com sua "xaninha", comparando, medindo. Só teve certeza de que não faria outra intervenção para retoques com seis ou sete meses.

Vendo-se a si mesma nos dias de hoje, reflete:

[...] Nós continuamos sendo a mesma pessoa. Alias, não é que éramos alguma coisa, somos continuidade de nosso todo. Somos quem sempre fomos... Nascemos mulheres, nascemos com pênis, uma anomalia... Entende? Como se fosse uma anomalia genética [...](pausa) Quando as pessoas nascem com uma mutação genética... Então, um erro ali, uma coisinha, um dedo a mais... Então, é só isso!

De volta ao Brasil, ela teve de se adaptar à nova vida. Não era nova para ela, mas para a comunidade que a viu nascer e crescer, pois embora todos soubessem que se tratava de uma moça, insistiam nos pronomes masculinos "ele", "o", entre outros; seja pelo "costume", seja por deliberada maldade. Ser reconhecida como mulher, sujeita do sexo/gênero feminino lhe tomou anos e anos de paciente "doutrinação" das pessoas quanto aos tratamentos que ela desejava lhe fossem observados.

\footnotetext{
${ }^{138}$ Importante mencionar que as sujeitas que custeiam suas cirurgias, geralmente conseguem se operar muito mais cedo que aquelas que aguardam nas intermináveis "filas" do SUS. Não conseguimos coletar dados nesse sentido (as clínicas particulares não disponibilizam essas referências, tão pouco o SUS traça um perfil de alcance público sobre as sujeitas), porém tal afirmativa é fruto de conversas informais com as interlocutoras que possuem amigas e conhecidas que realizaram as cirurgias na iniciativa privada e pelo SUS.
} 
Relembrando o capítulo primeiro, o historiador Thomas Laqueur ${ }^{139}$ nos conta que por milhares de anos acreditou-se que as mulheres possuíam genitália absolutamente igual a dos homens só que invertida para dentro do corpo: "as mulheres são homens virados para dentro" (: 16). No "Modelo de sexo único", o homem era o cânone ("a medida de todas as coisas"), a mulher versão menos perfeita e hierarquicamente inferior. Essa visão perdurou até o século XVIII. Por volta de 1800, já se instaurava o "dimorfismo radical" entre mulheres e homens, não apenas distintos no sexo, como no corpo e na alma: diferenças em graus microscópicos (: 17). Na visão do autor, o que se consideraria questão de "gênero" na atualidade, foi por milhares de anos uma definição "primária" ou "real" em relação ao sexo ou ao corpo, esses epifenômenos daquele (: 19). Assim, a diferenciação dos sexos foi um fato intencionalmente político, criando formas de construir os sujeitos e as realidades sociais (: $22-23)$.

Bruxa Malvada do Oeste, em suas palavras, consertou cirurgicamente uma "anomalia" na área genital. Em se tratando dela, nunca realizou qualquer transposição radical de personalidade que permitisse aos demais pensar nela como "ele". A questão era meramente física. Mas, como visto em Laqueur, após a modernidade ${ }^{140}$ não se trata de mera questão genital, mas de incomensurabilidade entre seres opostos, tão radicalmente diferenciados que não se assemelham em nada.

Entretanto, para Bruxa Malvada do Oeste, o êxito da tarefa é evidente: completamente inserida nos meios sociais, ela muito raramente tem de se explicar:

A minha intimidade eu tenho muito apreço. Não gosto de falar de cirurgia. Nem acho necessário falar dessas coisas. Também não faço masturbação mental pensando no que as pessoas vão pensar.

\footnotetext{
${ }^{139}$ Ver debates às páginas 29-32.

${ }^{140}$ Diversos autores abordam a modernidade como ponto de mudança social, científica, política, entre outros aspectos. Nos termos de Laqueur, a diferenciação sexual foi um projeto bem sucedido da racionalidade advinda com o iluminismo, com óbvios objetivos de controle de pessoas e grupos.
} 
No campo profissional, inicialmente retomou o trabalho de cabelereira, e foi convidada a trabalhar numa ONG de Direitos Humanos de pessoas LGBTTT ${ }^{141}$. Aquele espaço pretensamente "acolhedor" da "diversidade sexual" ${ }^{142}$, tornou-se mais um de exclusão, onde a "política de letras" tem precedência às pessoas:

Esses gay se travestis que conheci, porque eu fui inserida nesse mundo depois. Eles me conheceram já "Bruxa Malvada do Oeste". Eu não tinha um pingo de malícia. Isso foi meio chocante depois. Era malicioso?! Aquela pessoa estava sendo maliciosa comigo?!

Igualmente não compreende a necessidade de "codificação" ou "categorização" daquilo que chamam de "transexualidade". Para ela, "[...] tem de ser revistos esses parâmetros. Deixar aberto algo onde a sujeita saiba se definir, onde ela possa dizer quem é e o que quer: 'eu preciso disso aqui para me autoafirmar como mulher"'.

A interlocutora acredita ser impossível aos "especialistas da vida alheia" ${ }^{143}$ saberem mais do que a sujeita que vive e sente. Para a chancela da cirurgia, ela pergunta:

Eu acho impossível que uma pessoa ache que sabe mais de você do que você mesma. Como que aquele cidadão ali na esquina, sei lá, um profissional, em seu nome pode saber de ti? Está entendendo? Você que vive, que sabe dos seus anseios, dos seus problemas, das suas mágoas, das suas frustações, de teus desejos, de ti. Como que essas pessoas podem definir a tua vida? Se tu pode ou não fazer a cirurgia. Está entendendo? Porque a impressão que passa é que se eles não autorizarem você não vai fazer.

Numa palavra: "é humilhante!"

Mas Bruxa Malvada do Oeste está confiante:

\footnotetext{
${ }^{141}$ Sigla dos movimentos sociais que englobaria as especificidades de "Lésbicas, Gays, Bissexuais, Travestis, Transexuais, Trangêneros, Intersexuais e Queers". Algumas organizações internacionais utilizam a sigla LGBTTTIQ. Ver em:

http://www.cwhn.ca/en/LGBTTIQdefinitions

último acesso em:01/05/15.

${ }^{142}$ No mesmo sentido de "agrupamento" de identidades, o termo se refere aos LGBTTTs. Importante notar que as especificidades de cada "identidade" contida na letra não é consenso e, frequentemente, gera conflitos nas questões sobre representação ou legitimidade.

${ }^{143}$ Como visto na introdução, esse termo é utilizado aqui para descrever médicos, psicólogos, juízes, promotores de justiça, advogados, acadêmicos, pesquisadores e demais terceiros que pretensamente se creem "especialistas" na vida de quem demanda cirurgias de adequação da genitália.
} 
Eu acredito que daqui a vinte, vinte e cinco anos, talvez nós sujeitas, e todos os sujeitos e todas as sujeitas, vão poder falar sobre si e vai haver milhões de possibilidades. Milhões de categorias ou até mesmo sem categoria nenhuma, que era o ideal. Mas haverá outros questionamentos. No momento, eles querem ter controle sobre alguma coisa, mas o mecanismo de controle é errado, pois qualquer um pode burlar as categorias.

Como visto no capítulo introdutório, os cânones e modelos médicopsicológicos e jurídicos não servem para identificar as sujeitas. No máximo funcionam como "funil" do tráfego estatal de encaminhamentos cirúrgicos, em se tratando de pessoas que buscam a saúde pública. Para as clínicas particulares, o "laudo" é uma segurança para o profissional contra eventuais processos de reparação judicial, mas não para a proteção da sujeita. Num dos requisitos internacionais $^{144}$ (não abertamente declarado, mas claramente compartilhado), a postulante deve ter ojeriza ao pênis, caso contrário não será diagnosticada "transexual" e menos ainda direcionada à cirurgia. O abismo entre essa visão estereotipada e a realidade das sujeitas é grande. Bruxa Malvada do Oeste declara:

São mais claros para mim meus problemas hoje do que antes [da cirurgia]. Antes eu botava a culpa no pênis por tudo. Agora que não existe mais, posso ver que sou eu mesma a responsável, não o pênis.

O termo "transexual" foi para Bruxa Malvada do Oeste a definição de um processo corporal com fim certo: a cirurgia. Ela compreendia a definição do que se chama de transexualidade enquanto não chegava o dia da intervenção. Para ela, a cura do problema:

O momento da cirurgia é como se fosse um...(pausa) Se é uma síndrome, distúrbio de identidade de gênero, eu via a cirurgia como o remédio da cura dessa síndrome. Então, eu vou deixar de ser transexual para ser mulher e só.

Inviável que fosse vista ou reconhecida como "transexual" após a cirurgia. Assim, soava como ofensa ao ser comparada com "transexual":

Se estou falando que não sou, devem me escutar. Esse termo é ruim. Não é agradável, não é um elogio, né? É coisa negativa. Se transexual fosse qualidade, estava todo mundo lutando para ser "trans".

\footnotetext{
${ }^{144}$ Ver critérios de acesso à transgenitalização no capítulo anterior.
} 
Em determinadas situações, o não reconhecimento da identidade da indivídua pode gerar o insulto moral. Como visto no capítulo introdutório, para Luís Roberto Cardoso de Oliveira, o reconhecimento tem de se dar sem que esse seja obrigatório: primeiro porque não supre o pretendido; segundo porque não encontra meios legais ou jurídicos coercitivos para sua observação. $O$ ato de reconhecimento deve ser autêntico, recíproco e contínuo para que as relações se perpetuem, como inspirado na ideia de dádiva formulada por Mauss ${ }^{145}$. Deve demonstrar ser a "pessoa digna de apreço e consideração." ${ }^{146}$

Uma vez realizada a cirurgia e com sucesso, a busca agora era pela normalidade, ser vista e aceita como mulher, sem nenhuma ressalva:

Qual quadradinho eu tenho que colocar aqui? Não tem aquele normal não? Eu quero aquele normal!

Os relacionamentos afetivos com os homens foram conflituosos, sobretudo antes da cirurgia. Quando tinha 21 anos, namorou por quatro anos um rapaz dez anos mais velho. A família dele a acolhia como nora, torcendo pela união do casal. O afeto era recíproco, mas as dificuldades em razão de expectativas relacionais diferentes, questões profissionais, o escândalo do jornal, entre outros motivos, acabaram por separá-los. Após a cirurgia tentaram reatar. Ela acreditava que seria diferente, mas não foi ("ainda assim não era o relacionamento que eu queria."). Por duas vezes sofreu muito pelo mesmo homem. Refeita da desilusão, arrumou outro namorado em 2007. Dessa vez, ele era cinco anos mais jovem. Porém, a família foi contra ("nunca me senti tão excluída!"). Ele terminou a relação, escolhendo ficar com a família. Anos depois, em 2011, conheceu outro rapaz através da internet, num sítio de encontros eróticos. Ele morava em outra cidade, entretanto iria prestar vestibular na cidade dela. A visão contemporânea dela sobre a relação é "destrutiva", ato de insegurança dos primeiros anos após a cirurgia. Ela tinha muito ciúmes dele, controlava tudo: horários, senhas de e-mails e redes sociais. Chegou a discutir com a mãe do rapaz ("eu me rebaixei à adolescência!").

\footnotetext{
${ }^{145} \mathrm{Em}$ diversos artigos, Luís Roberto Cardoso de Oliveira relaciona as experiências de ausência de reconhecimento e com ofensa à dignidade e violência moral às ideias de Mauss sobre a dádiva em "Ensaio sobre a Dádiva: forma e razão de troca nas sociedades arcaicas".

${ }^{146}$ Luís Roberto Cardoso de Oliveira em "Dimensões da violência: conhecimento, subjetividade e sofrimento psíquico." (2011: 5).
} 
Neste momento, Bruxa Malvada do Oeste inicia outro percurso na vida: a graduação no curso de psicologia numa universidade federal. Autodidata, leu e estudou sobre o tema antes de escolher o curso. Com ousadia ("eu sou muito ambiciosa!"), pretende contribuir academicamente, deixando sua marca numa linha de abordagem da psicologia e em psicanálise que atualize as ideias lançadas por Lacan $^{147}$, na percepção dos conflitos que não havia à época, permitindo que novos sujeitos e sujeitas, quebrando as rotulações, possam ser inseridos ("sem ressalvas"). Em Freud ${ }^{148}$, tenciona contextualizar a histeria feminina, apostando que o desejo das mulheres pela emancipação nos espaços sociais foi muito (muito!) mal interpretado pelo autor, por isso pretende iluminar o entendimento equivocado.

O capítulo foi estruturado pela fala da interlocutora. São os tópicos protagonizados por ela que desenham e delimitam os assuntos, as cenas buscadas na memória. O leitor concordará conosco que Bruxa Malvada do Oeste articula sua própria vida de maneira tão própria, tão simples, que a intromissão excessiva poderia atrapalhar as ideias dela. Por isso, há trechos mais longos mesclados com apontamentos analíticos. Separamos o capítulo em "cenas" para aglutinar melhor as falas. "Limpamos" um pouco o texto retirando hesitações excessivas. Porém, evitamos fazer cortes ou supressões significativas que não permitissem a conclusão do pensamento.

\section{Discussão teórica: A situação liminar e o rito de passagem secreto.}

Como se verá mais enfaticamente nas páginas a seguir, Bruxa Malvada do Oeste vê a situação que se chama de transexualidade como algo temporário, um processo, cujo rito de passagem, por suas peculiaridades deve permanecer em sigilo. Para ela "transexual" e "transexualidade" só têm sentido até o momento da cirurgia de adequação da genitália. Depois, a sujeita volta a ser o que sempre foi: mulher, porém dessa vez plena. Agora não há mais a situação que poderia ser vista como de "liminaridade", pois com a adequação do corpo e as alterações documentais, a sujeita encontrar-se-ia completamente inserida na sociedade.

\footnotetext{
${ }^{147}$ Refere-se ao psicanalista francês Jacques-Marie Émile Lacan.

${ }^{148}$ Ver: Sigmund Freud.
} 
Victor Turner (2013) em "O processo ritual: estrutura e antiestrutura" analisa as situações do drama social entre sujeitos de determinados grupos, cujos rituais são fundamentais para o restabelecimento do sistema. Turner define a liminaridade como "a passagem entre status e estado cultural que foram cognoscitivamente definidos e logicamente articulados". Para o autor, as "passagens liminares e 'liminares' (pessoas em passagens) não estão aqui nem lá, são um grau intermediário" e podem ser tanto criativas quanto perigosas, na manutenção da lei e da ordem, quando da "libertação dos controles estruturais" sociais. Às relações entre liminares Turner nomeia por communitas e nesses relacionamentos os indivíduos não se vêm segmentados, estratificados, mas "encaram-se como seres humanos totais". Assim, se está diante de dinâmicas relacionais entre uma estrutura social subjacente e uma "antiestrutura" (formada por liminares e communitas) como "fonte de todas as instituições e problemas culturais" (: 13-14).

Nos rituais do povo ndembus o autor interpreta a simbologia presente na visão de mundo como um "modelo de estrutura semântica". Para essa tarefa, toma a análise de rituais como o "Isoma" (pertencentes às classes de "rituais das mulheres" ou "rituais de apropriação") no dever de "venerar as sombras dos ancestrais" cuja negligência da vítima torna-a temporariamente incapaz de gerar filhos. Tais ritos de cura têm como um dos objetivos fazer com que as mulheres se lembrem das obrigações perante as antepassadas diretas (mães, avós) sobre o "dever básico de fidelidade aos seus parentes matrilineares" para o reequilíbrio da sempre tensa estrutura formada pela descendência matrilinear e o casamento virilocal (: 26-33). Naquela realidade, os rituais são públicos e contam com a participação do marido, dos "peritos", médicos, pessoas que outrora passaram pelo Isoma e mesmo participantes de grupos ou aldeias vizinhas. Há também uma fase de segregação em que só o médico e o marido da enferma têm acesso. Após todas as etapas do ritual, a mulher estará novamente ligada à ancestralidade materna e apta a gerar filhos.

Trazendo as concepções de Van Gennep, o autor afirma que todos os ritos de passagem ou de "transição" possuem três fases: a de separação (afastamento de um sujeito ou grupo de um ponto fixo anterior na estrutura social ou do conjunto de condições culturais, o que chama de "estado"); de margem (no período liminar o sujeito tem características rituais ambíguas, com pouco ou quase nenhum dos atributos do passado ou do estado futuro) e a agregação (de 
reagregação ou reincorporação). Após, a estabilidade espera-se que o sujeito se comporte de acordo com as expectativas de sua posição social (: 97-100).

Em comparação com o estudo de Turner, em alguma medida o que se nomeia por "transexualidade" pode ser vista como uma situação liminar: uma vez cumpridas às etapas, adquire-se o "novo estado". Entretanto, para as sujeitas esse "novo estado" sempre esteve presente, aguardando apenas a cirurgia e modificações documentais para a segurança ou conforto interno e o exercício da cidadania. Outra ressalva se encontra na extrema privacidade dos ritos de passagem do que se chama de "transexualidade". Tanto a cirurgia (com ou sem demais intervenções, como seios, depilação a laser para os pelos, etc) quanto às mudanças nos documentos civis não costumam ser publicizadas ao contrário, são mantidas em absoluto sigilo, pois apenas assim poderá ter uma vida "normal como a de quaisquer outras mulheres".

\section{Os rituais públicos de humilhação.}

Mariza Peirano (2002) em "O dito e o feito: ensaios de antropologia dos rituais" "19ilumina as discussões sobre os rituais. Com o objetivo de "situar a análise de rituais na história teórica da antropologia e seu vínculo com o exame de eventos contemporâneos" apontando suas consequências disciplinares e políticas (: 17), Peirano passeia pelos temas clássicos da disciplina, suas discussões e avanços. Aparecem para nós os pares dicotômicos: magia e ciência; mitos e ritos; e também a eficácia maussiana e as análises dos rituais por Stanley Tambiah, entre outros (: 1828).

A autora passa então a elaborar as ideias sobre os rituais. Concordando com Tambiah, conceitua os ritos como "[...] sistemas culturalmente construídos de comunicação simbólica" com eficácia social (: 27). Tipos de eventos sociais e/ou culturais. Para Peirano, o ritual, assim como a linguagem "esclarece mecanismos fundamentais do repertório social" que são "bons para revelar processos também existentes no dia-a-dia e, até mesmo para se examinar, detectar e confrontar as estruturas elementares da vida social" (:29).

${ }^{149}$ Rio de Janeiro: Relume Dumará: Núcleo de Antropologia da Política/UFRJ, 2002. 
Em Tambiah, a autora destaca os episódios de violência coletiva com grande repercussão social e midiática - os riots ${ }^{150}$ - extraídos da obra "Leveling Crowds", voltada para as discussões analíticas sobre os centenários conflitos etnonacionalistas e a violência coletiva que assola de tempos em tempos o Sul da Ásia (: 30 ). No processo de enfocar a rotina da violência coletiva, Peirano (assim como Tambiah) busca compreender: "Por que brutalidades cometidas por membros da multidão inflamada em nome de uma causa política 'válida' para uma coletividade [...] não deixa marcas psíquicas no agressor no plano individual". E, igualmente, tencionam entender como, após a curta duração dos espasmos de violência, as pessoas retornam rapidamente as suas vidas normais, convivendo com os mesmos inimigos que haviam desferido atos de violência. Para ambos, a resposta está no caráter ritualístico dos riots (: 32$)$.

Como se viu acima e se verá mais detidamente nas próximas páginas, Bruxa Malvada do Oeste foi ritual e publicamente humilhada quando não se contentou com o lugar masculino erradamente atribuído a ela, enfrentando a diretora da escola (e toda a sociedade) ao vestir-se com uniformes femininos. Embora com consideráveis significações de contextos entre os "riots" orientais e as humilhações praticadas contra as interlocutoras na realidade brasileira, o rito público foi a maneira encontrada pelas autoridades para "castigar" as pretensões de deslocamento simbólico da sujeita, comunicando, entre diversas mensagens possíveis, duas em especial: ela não seria vista ou reconhecida como mulher nos ambientes escolares a partir daquela data e; ao ser obrigada a se vestir com uniformes masculinos, lembraria a quaisquer outras sujeitas que porventura tencionassem algo similar que elas teriam o mesmo destino.

Entretanto, tal rito não é caso isolado. As quatro interlocutoras desse trabalho sofreram incontáveis situações que podem ser lidas como "rituais públicos

\footnotetext{
${ }^{150}$ A autora descreve os riots como "[...] espasmos de violência que se repetem um após outro, saqueando, depredando, tirando vidas, destruindo propriedades, provocando incêndios, amedrontando e causando pânico, fazendo vítimas e traumatizando a população [...]." Mais a frente, prossegue na precisão da descrição dos eventos de violência coletiva como "[...] incidentes locais e de pequena escala, ocasionados por disputas religiosas, comerciais, familiares, envolvendo pessoas em contato direto, crescem cumulativamente até tornarem-se grandes questões abrangendo um grupo que se vê como étnico e que, sob a influência de rumores de atrocidades, engaja a população por meio de lealdades e antagonismos que dizem respeito à raça, religião, língua, nação, lugar de origem" (: 31).
} 
de humilhação" em razão das suas identidades. Nos capítulos a seguir, se explicitará alguns.

\section{Cenas de Vida.}

Do momento em que Bruxa Malvada do Oeste foi me pegar no aeroporto em 12 de junho de 2014 até o dia da despedida, dialogamos sobre diversos assuntos. Muitos sem nenhuma relação com a pesquisa. A ordem das falas a seguir é aleatória, como aleatórios são os interesses de pessoas numa conversa despretensiosa: as lembranças, os risos, os momentos tensos. Procurei manter fieis os trechos em que ela disserta sobre sua vida, seus caminhos e temas. $O$ direcionamento dos assuntos foi necessário apenas para levantar determinado assunto. O título e uma pequena descrição marcam a temática daquele trecho.

\section{As memórias da cirurgia.}

Em seu quarto e já com roupas de dormir, perguntei a ela sobre suas memórias da cirurgia. Ela narrou fragmentos de lembranças. Em alguns momentos, preocupava-se com a recuperação cirúrgica; noutros, se poderia ter ou não orgasmos após a intervenção. Como despedida do pênis com que viveu muitos anos, masturbou-se pela última vez, na discreta cerimônia do último dia:

Então, essa foi a cerimônia do ultimo dia com o pênis. Dormi no hotel. Masturbei-me. O amigo da minha psiquiatra, Dr. Sicrano e sua namorada, me levaram pra comemorar o fim de meu cativeiro, e eu havia tomado muito vinho. Tomei um banho, tudo direitinho. De manhã, acordei as sete. Tomei café da manhã. Só que café da manhã não muito pesado. Depois não podia comer mais nada. Entrei na clínica as nove. Já havia me depilado, mas lá eles fizeram tudo de novo. Foi muito constrangedor... A enfermeira segurando meu pênis, puxa para lá, puxa para cá...Era muito constrangedor e invasor.

Às sete da noite eu entrei para fazer a cirurgia. Foi o dia inteiro nessas coisas desses exames. Eu levei um terço na mão, também, né? Eu tinha minha religiosidade... Aí me deu vontade de fazer xixi na hora, na mesa, e era nervosismo, 
não era vontade de fazer xixi... - "Ela quer levantar pra fazer xixi". - "Pipi, pipi!" - que eu não falava inglês, né? Para não ter que ir ao banheiro, colocaram uma bacia embaixo. Eu sei que eu apaguei, contando aquele negócio do soro, contando até dez. Nossa, contei duas vezes.

\section{Orgasmo após a cirurgia e os cuidados pós-cirúrgicos.}

Demorei dois anos certinho para ter orgasmo de novo, após a cirurgia... (pausa) Demorei muito, eu acho!

Perguntei-Ihe se havia tido algum problema que dificultasse o prazer:

Eu tinha um bloqueio. Eu era muito religiosa. Eu tinha uma religião, que pregava aquela culpa toda e tudo o mais. Então, eu achava que tudo era pecado. Eu levei isso para o pós-cirurgia. Eu levei essa cultura, sabe? Eu sempre reprimi muito a minha sexualidade. Sempre fui muito reprimida, muito sofrida. Não sabia lidar com a sensualidade, sabe? Então, demorei muito mesmo! As minhas primeiras relações sexuais não tive orgasmo. Tive relações acho que cinco meses depois da cirurgia. Eu vim para o norte do País e aqui é quente. Não é um lugar propício para o pósoperatório desse tipo, porque pode infeccionar. Eu tinha muito medo. Por isso fiz as dilatações direitinho. (risos) Eu cheguei a usar eles como masturbadores mesmo, para o orgasmo (risos). A minha dilatação na verdade, não era de fazer exercício. Era colocar lá por seis horas seguidas: duas de manhã, duas de tarde, duas de noite. Eu fazia tudo direto, seguido. Por causa do calor, da falta de privacidade...Estava na casa da minha mãe. Eu vim de Paris para São Paulo, foram doze horas e eu fiquei... Imagina aquilo lá dentro, sentada, não tinha como sentar. Quando eu tirei sangrou. Foi a primeira vez que sangrei e fiquei tão preocupada. Será que caiu algum ponto, alguma coisa? Eu fiquei muito preocupada... Graças a Deus não tive problemas.

\section{Trajetória dos momentos da cirurgia: garantia de segurança.}

Como parte do planejamento para a realização da cirurgia, Bruxa Malvada do Oeste, cercou-se de todos os cuidados e, segundo suas crenças, fora ajudada por forças externas superiores para que os detalhes encaminhados levassem ao 
êxito. A qualidade de uma vagina e vulva funcionais e esteticamente completas, e a segurança nos procedimentos foram itens fundamentais na escolha do lugar e do profissional ${ }^{151}$.

Esse primeiro momento da cirurgia, foi tudo muito mágico, no sentido de tudo dar certo. Tudo se encaixando, tudo na hora certa. Eu não falava inglês. Não falo inglês. Para viajar pra Tailândia, tinha de ter uma pessoa que me amparasse que falasse italiano. Teve a minha psiquiatra que me acompanhou que fez os testes para diagnosticar, né? Nós superamos as relações profissionais, ela ficou muito minha amiga. Na verdade, só fiz lá na Tailândia porque ela ajudou a organizar muita coisa. A pessoa que iria me acompanhar e tal. Fiz todo um tour por varias clinicas que tem lá com essa pessoa que me acompanhou. O amigo dela. Ele era médico, né? Isso foi muito bacana! Em uma das clínicas, conversei com o médico. Senti-me muito segura. Ele me disse: "vai ser assim, vai ser assado. Você vai ter orgasmo!" Olhou meu pênis antes da cirurgia: - "vai ser muito profunda(risos). Vai ter material suficiente. Não vai dar trabalho." E me garantiu, sabe? Garantiu-me que seria tranquilo! E como eu era religiosa - acabei de falar para ti - eu jogava tudo na mão de Deus, se fosse da vontade Dele que eu morra, que seja de buceta! (risos).

Retomamos ao assunto da cirurgia. Desta vez ela narrou as diferenças no tratamento dado às adequações genitais em Bangkok, na Tailândia. Naquele país as cirurgias são realizadas pela inciativa privada há muitos anos e conhecidas mundialmente pela perfeição das técnicas e resultados. $O$ acesso as intervenções é relativamente livre, bastando que a sujeita comprove com laudo psicológico o sofrimento pela a insatisfação com a genitália (Gender Identity Desorder) e a necessidade/vontade de "reparação", "adequação" ou "readequação" ${ }^{152}$, bem como tenha condições financeiras para custear os procedimentos que são oferecidos em portfólios, com diversos modelos de vulvas e os respectivos preços. A paciente escolhe absolutamente tudo:

\footnotetext{
${ }^{151}$ Atualmente no Brasil pela rede pública de saúde não é possível tal escolha. Como visto no capítulo introdutório, são apenas quatro os hospitais que atendem todo o País: Goiânia, Rio de Janeiro, São Paulo e Porto Alegre.

${ }^{152}$ A literatura médica utiliza com frequência o termo "readequação" ou "redesignação" Ambos têm relação com "nova" configuração, radicalmente diferente da original. "Reparação" tem o sentido de reconstrução e é encontrada quando se refere a mutilações. Utilizamos aqui o termo "adequação" pensando na busca da sujeita em "conformar" a genitália de nascença à sua identidade vivida.
} 
Eu saí do hospital com quinze dias. Eles falaram para mim: - "Tu só vai sair daqui fazendo xixi e evacuando normal." Com o valor que eu paguei, eu tinha esses quinze dias incluídos. O pacote incluía os quinze dias lá no hospital, a cirurgia e toda a alimentação. Um tratamento de primeira. Se acontecesse desses quinze dias eu não conseguir, tivesse problemas pra fazer xixi, blá, blá, ia se prolongar tudo por conta da clínica. Eu só ia sair dali se não tivesse nenhum problema para fazer xixi... Muito boa a clínica [PAl, clínica do Dr. Preecha]. E o médico era maravilhoso! E não é tão caro. Eles anunciam um valor. Não que tu vá pechinchar, chega lá eles fazem uns cálculos e tudo sai por menos. Até porque tu estando fora, eles querem fechar o negócio contigo aqui no Brasil ainda e tu indo para lá, para fechar o negócio lá, tem inúmeras clínicas. Então, eles se sentem obrigados... [a cobrir a oferta]. Não que você vá pechinchar, eles te dão todo um amparo, te prometem isso, prometem aquilo outro, prometem um monte de coisas, para que tu se decida a fazer lá.

Então, como eu fui pra lá sem fechar negócio com clínica nenhuma, tinha outra muito boa, que era bem mais barata e que eu fiquei muito inclinada a fazer. O único problema que eu fiquei arrasada, foi o seguinte: no andar de baixo, no primeiro piso, funcionava um pronto socorro público. Então, antes de entrar na clínica, tinha uma entrada e você passava e via as mazelas da população. Só aí você subia. Então, era um misto de particular e tinha um pronto socorro lá embaixo. $E$ as meninas asiáticas, tailandesas, japonesas, todas aquelas da comunidade dos tigres asiáticos, elas pagavam muito menos que quaisquer outras... Que italiana, que brasileira, que americana. Pagavam tipo, muito mais barato, só que elas tinham um tratamento assim: Dividiam quarto, quatro [meninas] num quarto só, tá entendendo? Eu paguei um valor que talvez tenha sido o triplo do que elas pagam, mas eu fiquei sozinha. Com todo um amparo. Como eu não tinha ninguém, a enfermeira chefe fez todo um trabalho psicológico. Fez aquele papel da mãe. Como ela arrumava uma língua para falar comigo eu não sei, mas a gente se entendia (risos). Ela me dava atenção e cuidados. Fui muito bem servida, muito bem cuidada, muito bem tratada. Tinha até massagens nos pés para relaxar. Senti-me uma dondoca! Na Tailândia eles fazem um portfólio de vários modelos para você escolher qual que você quer. É tão variado que tem até um cardápio. Tem seios e cirurgias de tudo que você imaginar. 


\section{No sétimo dia, uma surpresa!}

Eu me lembro dessa questão eu não falava tailandês ou inglês. Não sabia o que eles iriam fazer no sétimo dia. Lavaram-me na cama, me levaram de maca para uma salinha, me aplicaram uma anestesia bem leve no local. Eu ainda não sabia o que eles iriam fazer. Eu sentia um soro, uma água escorrendo. Daí tiraram tudo [os curativos]. Cobriram tudo e me levaram para o quarto de novo. Eu não sabia que eu estava sem curativo, sem nada. Ele (o medico) levantou o lençol e tirou de dentro de mim um tutor [espécie de molde colocado dentro do novo canal vaginal]. Ele disse: “Very good! Very good!". Eu fui para o espelho, não podia ainda fazer xixi, mas podia fazer cocô. Aí, no espelho do banheiro, um espelho inteiro, eu levantei a roupa e chorei. Minha "xaninha"! Tão linda, tão linda, que bom é verdade! Agora eu tenho realmente. Uma coisa harmoniosa. Parecia que eu sempre fui daquele jeito e chorei e liguei para a mãe. Depois eu comecei a olhar os defeitos. Não era tão bonitinha, eu vou confessar. Só fui ter certeza de que eu não ia fazer retoque algum acho que com seis, sete meses depois, já aqui no Brasil, que aí eu já vi realmente como ela ia ficar.

\section{Contar sobre a cirurgia ou falar sobre o passado.}

A minha intimidade eu tenho muito apreço. Não gosto de falar de cirurgia. Nem acho necessário falar dessas coisas. Também não faço masturbação mental pensando no que as pessoas vão pensar. Já fiz muita, fiz muita, essa siririca mental. Preocuparme se as pessoas sabem ou não sabem, se elas acham que sou travesti, se elas acham que sou sapatão, se elas acham que eu sou mulher normal, se sou mulher estranha. Não me interessa mais essa especulação porque quanto mais você tem esse tipo de preocupação, isso te dá uma insegurança e aumenta mais ainda... Então, assim, não penso mais sobre isso Tem algumas pessoas do meu círculo de amizades que sabem. Com outras, houve naturalmente um afastamento. Nos relacionamentos as coisas são imprevisíveis. O tempo nos distancia de algumas pessoas, algumas situações se perdem. Então, não culpo a cirurgia por ter me distanciado de algumas pessoas. Não culpo. Com os poucos do passado que sabem e participam, não me sinto mal. Não faço essa masturbação mental. 


\section{E contar sobre o passado?}

Contar para quem? Acho que num determinado momento de um relacionamento afetivo, se o indivíduo vai saber de alguma forma, melhor que seja da sua boca. Se pretende viver uma vida a dois de longo prazo, desde que não seja para "ver no que vai dar", contar pode ser necessário. Tem de ter a sutileza de perceber qual é a perspectiva do meu parceiro, o que ele espera de mim. Ele espera um filho de mim? Se espera, para quê fazer esse homem sofrer? Vamos ser sinceras! Se você não quer se expor você mesma pode cortar a história. Agora, eu não vou conhecer um cidadão hoje ou namorar por uma semana, duas, um mês e expor uma coisa que ele nem quer saber, nem precisa saber. Eu não acho necessário em alguns momentos! É necessário em contextos, dependendo do contexto. Então, todas somos mulheres de contextos... Somos mulheres de contexto! Num contexto " $x$ " é necessário, num outro contexto, não! Para que, né?

\section{"Ofende-me a especulação sobre meu passado".}

Alguém saber da minha história do meu passado, não me ofende. Eu tenho uma história anterior à cirurgia. Infelizmente não nasci no dia da cirurgia. Não me ofendo quando as pessoas sabem. Ofende-me a especulação sobre meu passado. Ofendeme que as pessoas fiquem querendo, curiosas em saber dele. Essa curiosidade me ofende. Agride-me agir como se estivesse juntando um quebra-cabeça: - "Por que ela é assim?" "Por que a voz dela é assim?" O fato de que eu não nasci com vagina é um fato verdadeiro, mas me atribuir outra sexualidade que não seja a minha me ofende.

\section{Última surra da adolescente Bruxa Malvada do Oeste.}

Bruxa Malvada do Oeste rememorou a última surra que levou da mãe em razão de vestir roupas femininas. Ela resistiu e manteve a identidade feminina a despeito da dor, conquistando o respeito da família e da comunidade.

Minha última surra, eu estava com roupas femininas. Minha mãe não entendia muito essas questões de feminilidade. Por ela eu poderia ser gay e tá tudo muito bem. Fomos eu e uma amiga para um show de rock que acontecia no centro. Minha 
amiga namorava um rapaz de uma banda. Eles me viam com ela e achavam que eu era uma garota, uma menina, como se diz...?Andrógena, uma roqueira! Nesse dia eu queria ir mais bonitinha porque eu estava a fim de um garoto e ele de mim. A blusa era da minha irmã. O batom emprestado de uma amiga. E nisso a gente ficou até tarde. Tinha uma Kombi do juizado de menor catando só menores depois das dez da noite e deixando em casa. Pegaram-me(pausa e risos). Documento não tinha e tal. Teve um cara lá que sabia quem eu era: -“Ah, já sei. Não é menina!” e ficou rodando comigo até dar tempo para dizer que me pegaram tarde na madrugada. Ele conhecia minha mãe. Acordaram minha mãe: - "tá aqui sua filha!" Apanhei como um ladrão quando é pego em fragrante, apanhei na hora. E de manhã apanhei mais (risos). Minha mãe me disse: "É a última surra que estou te dando!" Vou morrer, pensei- “Tu não tem mais idade de apanhar." Eu ia fazer quinze anos já. (pausa) Esse confronto com a minha identidade feminina, eu conquistei! Eu tomei minha identidade. Eu me impus! Houve surras, discussões! Não me expulsaram de casa, mas me deram gelo. Eu resisti! "E quando eles cansaram de brigar comigo, veio o gelo! Minha mãe ficou dois anos inteiros sem falar comigo e morando na mesma casa, eu já estava me apresentando como Bruxa Malvada do Oeste. Os amigos da minha mãe, os outros profissionais que trabalhavam com ela, passaram a me admirar: - "É inteligente, é educada! Totalmente diferente do que imaginávamos!" Chegavam para ela me elogiando. Isso fez com que a minha mãe passasse a olhar realmente a filha que ela tinha. E o momento do primeiro namorado, as dores, os sofrimentos, começamos a conversar. A coisa começou a fluir: - "Porque minha filha é a mesma pessoa". O que mudou? Os artigos finais o "o", "meu filho" - "minha filha", esses gêneros no linguajar mudaram. Mas no psicológico, na identidade que foi construída, não houve mudança. Já era uma identidade feminina. Talvez essa revolta, essa briga, essa censura que houve no primeiro momento, tenha sido uma forma de me proteger. Talvez, se eu fosse mãe eu temesse por alguém que eu conhecesse, uma adolescente iniciando a vida e acreditando no mundo.

\section{As questões educacionais.}

Tema recorrente nas falas, tanto na trajetória da Bruxa Malvada do Oeste quanto das outras interlocutoras, diz respeito ao repúdio ou acolhimento na escola 
ou em questões educacionais. Para ela, expressar-se como realmente é tornou-se "uma guerra". A impossibilidade total de a rede escolar acolher a menina cuja vida singular deveria inspirar maiores cuidados. Nesse ponto, vale relembrar os debates sobre rituais públicos de humilhação.

Eu já estava com roupas femininas, de menina, né? Uma pessoa me sugeriu de estudar algo na área da educação: - "Vá fazer magistério! Acho que tem muito a ver contigo". Entrei no primeiro ano do magistério. Fiz o teste tudo e passei. Fui matriculada. Só que tinham uniformes diferenciados: menino com calça cumprida, tênis e jaleco, e menina com saia ao invés da calça. E eu ia com uniforme feminino, lógico! Fiz o primeiro ano normal. No segundo ano também normalmente. Para a presença, eu chamava o professor num canto e explicava. Os professores que eram legais colocavam um "azinho" e davam sequência. Outros não faziam isso, mas eu dizia que estava presente, depois das aulas. No terceiro ano, a diretora falou assim: - "A partir de agora, você só vai ser matriculada se se comprometer a vir com seu cabelo amarrado, com o uniforme masculino!" Eu aceitei, porque já estava no fim, no terceiro ano, e se não aceitasse ia ter de estudar outras matérias e era praticamente começar tudo de novo. Não fui com o uniforme nos primeiros dias, porque não estava pronto. Ela me barrou na entrada. Eu fazia estágio em um programa para menor aprendiz. Estava trabalhando com advogados, daí a minha chefa me viu chateada, triste. Eu contei tudo. Ela disse: - "Mas isso não pode! Você tem direito à educação!" $E$ disse um monte de outras coisas sobre a Constituição e tal. A Secretária de educação a pedido da advogada fez um memorando e me deu. Eu fui cheia da razão. Foi uma guerra! Saiu em todos os jornais, a expulsão. O grêmio estudantil querendo que eu ficasse, a direção que eu saísse. Foi um circo, um circo, um circo! Justamente os gays, que tinha muito gay no magistério, reclamavam com a diretora que queriam também ir vestidos de mulher [para sabotar a demanda da sujeita, banalizando-a]. Todo mundo de mulher. Os homens barbudos queriam ir de mulher, pode? Foi horrível, horrível! Saiu no jornal local "a travesti normalista". Queriam me expulsar e tudo o mais. Aonde eu ia as pessoas me apontavam e comentavam: "Você não é aquela do colégio tal?" eu sei que acabou com a minha vida! Os gays fizeram isso comigo! ${ }^{153}$

\footnotetext{
${ }^{153}$ Nesse trecho ela explica melhor dizendo que "os gays", ao invés de compreendê-la e auxiliá-la quando afirmava que era mulher, alardearam a situação para ridicularizar o pleito da interlocutora.
} 
Apesar de saber da minha história, para ele [o namorado à época], todo mundo saber foi muito ruim. Queimou meu filme, queimou o filme dele. Não tive sossego. Acabou que fez das nossas vidas um inferno. Com muito esforço, terminei o magistério todo. Tive dificuldades para estagiar. A minha capacidade não pode ser julgada por um aspecto físico. Mesmo assim eu fui impedida de exercer a profissão justamente por não ter um rótulo para me encaixar: eu não era travesti, não era gay e para eles não era mulher. Então, não tinha onde me encaixar. Não havia possibilidades! Eu não aceitar ser travesti, foi a briga dos gays comigo. Foi a briga da sociedade com eles e comigo, porque eu já havia sido rotulada contra a minha vontade. Então, o direito não tinha portas. Porque a documentação me negava $o$ direito feminino, minha identidade feminina. A minha identidade social chocava quando tinham acesso aos documentos. Não tive problemas com os alunos, mas nas questões administrativas, os gestores tinham problemas de como me encaixar. Os estágios foram difíceis de conseguir. Depois, eu me intimidei e não procurei emprego.

\section{Prostituição.}

A interlocutora se prostituiu por cerca de seis anos na Itália. Em razão da falta de oportunidades laborais, se obrigou a suportar o ofício até juntar dinheiro suficiente para a cirurgia e também para dar um pouco de conforto a mãe. Diversas narrativas tratam o tema da exploração sexual explicitando os horrores pelas quais as pessoas passam para conseguir dinheiro, se manter e realizar seus sonhos. A da Bruxa Malvada do Oeste é repleta de memórias de violências diversas:

Convivi com gente horrível, vivi em lugares horríveis. Visões agressivas, ameaças. Aconteceu de eu ver pessoas em estado crítico, mesmo. Coisas horríveis como a menina que morreu do meu lado, na mesma cama. Eu me apegava muito às questões religiosas. Pensava: - "Isso não aconteceu comigo porque eu rezo, porque eu sou boazinha". Eu sentia que alguma coisa me protegia. Então, eu fui poupada de muitas coisas. Apanhei de uma travesti uma vez. Noutra, fui presa e me soltaram. A polícia da Europa tem uma cortesia com o cidadão. Um cliente uma vez puxou um canivete para mim, porque eu não o comi. Convivi todo dia com o perigo. Os estrangeiros que passavam de moto puxando bolsas, isso aconteceu bastante. Sofri 
muita, muita violência psicológica com clientes porque eu não os comia. As travestis diziam: - "Ela quer operar. Não vai gozar!" Com as cafetinas, fui submetida a tratamento desumano. Tínhamos de dormir na mesma cama em que fazíamos programa! Dormir três pessoas numa cama, no mesmo lençol. Teve a menina que morreu em 1999 e eu nem pude denunciar. Nem sei se os pais souberam. Ela era de Goiânia e se envolveu com o ex-marido da cafetina que era a bombadeira ${ }^{154}$. E ela me ligou: "Eu vou pôr silicone no peito. Vem para cá!" Ela mandou as passagens e eu viajei para ajuda-la. Nessa época eu não me prostituía, mas conhecia muitas meninas que trabalhavam assim. Ela me contou que teve um caso com o ex-marido de fulana: - "Eu queria que tu fiscalizasse se ela vai botar alguma coisa no silicone enquanto ela estiver me aplicando". Eu concordei e fiquei de olho, pareceu tudo bem, mas mesmo assim ela passou mal. Depois, disseram que era normal baixar a pressão e tal. Perguntei a ela se ela estava bem e ela me disse que sim. Que se sentia fraca, mas que parecia ser pela gripe. Então, fui ao cinema e quando voltei ela estava dormindo, estava quente com febre, dei um remédio antitérmico a ela efui dormir. Quando eu acordei de manhã ela estava fria, fria, fria. Morreu da aplicação do silicone, foi parar o coração. Livraram-se do corpo da menina. A cafetina e o exmarido a levaram para o pronto socorro. A cafetina disse que ela ficou no hospital tomando soro eu sabia que era mentira, porque ela já estava fria quando levaram. Depois que apareceu a história toda. Aí, a cafetina disse: - "Vamos mudar, todo mundo!" Quando eu voltei eles tinham se mudado de casa. Levaram tudo: - "Tuas coisas tão tudo lá em casa". Naquela noite me prostitui e juntei o dinheiro da passagem para ir embora. Todo o tempo eles faziam pressão psicológica: - "Cagoeta morre..." Me levaram até a rodoviária para ver se eu não ia falar com ninguém. Falei com a mãe dela. Nem sei mais o que aconteceu depois.

\footnotetext{
${ }^{154}$ Termo utilizado pelas prostitutas ou profissionais do sexo (mulheres, travestis, michês) para se referir as pessoas que injetam silicone líquido industrial nas profissionais. Como visto no capítulo introdutório, a etnografia de Don Kulick (2008) aborda essas e outras questões acompanhando as travestis de Salvador/BA.
} 


\section{Relacionamentos afetivos.}

Após o almoço, enquanto lavava louças e utensílios de cozinha, conversamos sobre relações afetivas. Ela me narrou três experiências marcantes de relacionamentos do passado. A primeira aconteceu antes e depois da cirurgia; a segunda e a terceira após.

Os familiares dele me aceitavam tão bem! Foi namoro mesmo. Depois, fui analisar direito e vejo que foi mais porque me sentia aceita, me sentia nora, me sentia participante de uma família... Em relação a ele, era coisa de energia mesmo, de pensar parecido, da gente se olhar e saber o que estava pensando. Tinha essa química toda. O problema é que ele sempre teve uma alta necessidade de liberdade. Ele estava apaixonado por mim, mas mesmo assim ele se fechava, ele sumia. Amar para ele era ter receio de alguém... Porque era assim que ele via as pessoas que se apaixonavam. Terminou porque ele era dez anos mais velho do que eu [ela: 21 e ele 30 e poucos anos], mas era uma pessoa sem estrutura. Tinha empregos rápidos. Aqui na região norte do País a segurança é trabalhar para o Governo ou ser empresário e tentar se estabilizar. A gente terminou também porque aconteceu a história do jornal... Ele perdeu o emprego por causa disso. Depois, ele conheceu uma mulher mais velha que era agente penitenciária. Ela engravidou dele. Ele disse que ia ficar com ela para abrir portas: "- Serei bem sincero: esse relacionamento que você espera, que toda mulher espera, eu não vou poder te dar. Porque eu não quero me casar!" Eles nunca se casaram, mas tiveram dois filhos, cada um na sua casa. Ele também se tornou agente penitenciário.

\section{Perder o amor da vida.}

Quando eu fui para a Itália eu estava na seguinte situação: já tinha perdido o amor da minha vida, a única coisa que me restava era o sonho de fazer a cirurgia. $E$ a oportunidade de fazer era ir para lá mesmo. Se eu ficasse aqui teria de suportar ela grávida dele, e eu não aceitava ser amante. Para mim, não bastava ter o sentimento da pessoa. Porque o único homem que eu tenho certeza que me amou na vida, foi ele! Eu tinha segurança dos sentimentos dele por mim e ele comigo. Ele sabia que eu não era capaz de me relacionar com outro, essa coisa bem machista. Então, eu fui ser puta na Itália, me sujeitar. Durante os seis anos que eu passei na situação de prostituição, a cirurgia era uma âncora para mim. Eu pensava que tudo mudaria 
depois da cirurgia, que depois da cirurgia eu não precisaria mais me sujeitar a nada daquilo... Quando eu me operei, voltei para a realidade da minha cidade. Não se deve iludir-se muito com o que vai mudar. A única coisa que muda é você com você mesma! No fundo a gente acha que vai ser mágico, melhor do que realmente vai ser... E que as pessoas vão esquecer o "ele". Apagar o "ele" da ideia das pessoas foi um processo longo. Querer fazer vida nova se deparando com a vida que as pessoas te esfregam na cara é muito difícil. Porque as pessoas te cobram: - "Você não era fulana?!" - Sim eu era fulana, mas agora mudei! -Tinha sempre essa cobrança. Voltei com esse meu ex-namorado achando que ia ser diferente. Ele estava solteiro, como sempre foi, mas ainda assim não era o relacionamento que eu queria. Eu olhava nos olhos dele e via por um lado a moça que eu era, a ingenuidade, sabe as coisinhas legais entre um casal? Mas tinha toda uma lembrança negativa. Eu queria casar no papel - eu disse isso para ele. Porém ele me lembrou de que ele não queria se casar e não se muda ninguém... Então foi tudo de novo, mais um sofrimento. Duas vezes, tudo de novo: o luto!

\section{$O$ afeto após a cirurgia.}

Em 2007 arrumo um namorado já depois da cirurgia. Uma pessoa de um nível cultural muito diferente do meu, mais jovem, mais para baixo (risos). Ele era vigilante. Ele sentia por mim aquela paixão juvenil, o fogo. Namoramos, ele tinha 26, eu já devia ter 31. Namoramos uns seis meses. Nisso eu esqueci o outro. A família do primeiro me acolhia, né? A desse segundo, eu nunca me senti tão excluída na vida! Eles diziam: - "Eu quero um neto!" Resultado: ele terminou comigo, porque disse que tinha de escolher entre eu e a família dele.

Em 2011 eu conheci um garoto na internet. Tenho muita vergonha dessa história, mas eu vou contar para você ter uma dimensão do quanto eu me sabotei, me saboto, escolhendo coisas que obviamente não me trariam nada. Eu o conheci num site adulto. Ele tinha 17 anos. Parecia uns 20 e pouco, mas dizia ter 20 anos. Só descobri a verdadeira idade dele um mês depois, porque pressionei, desconfiei pelas conversas. Ele estava se expondo na cam (câmera do computador). Mandei uma mensagem ele respondeu imediatamente e fomos para o msn (softwear de mensagens virtuais). Acabou que não teve aquela masturbação virtual. Ficamos só conversando. Ele me ligava aqui em casa todo dia. Ele ia prestar vestibular aqui e 
eram as férias dele. Apaixonei-me e pirei também. Eu comecei a controlar tudo. Ele me deu as senhas dele. Queria saber com quem ele havia conversado, a que horas chegava ou saia. Cheguei a discutir com a mãe dele. Eu me rebaixei à adolescência. Ele foi mais adulto do que eu. Fiquei remoendo essa história por muitos anos. Até hoje me pego pensando, não no garoto, mas no quanto posso ser destrutiva. Se eu for me envolver de novo com outra pessoa, posso repetir os mesmos vícios. Continuar mantendo relações na linha do impossível para eu não ser feliz. Talvez esteja no inconsciente. Decidi que vou trabalhar meus conteúdos inconscientes, me dedicar aos estudos, antes de me envolver de novo. Acho que vou ser uma solteirona com gatos como companhia (risos).

\section{A militância "trans".}

Após a cirurgia, Bruxa Malvada do Oeste não sabia ao certo o que fazer como trabalho. Conheceu um grupo LGBTTT e iniciou algumas atividades para outros segmentos (o de travestis), embora para ela já não houvesse mais sentido naquilo. Como visto no capítulo primeiro, no Brasil e em diversos países, é muito comum aquele movimento avocar para si as lutas de muitas sujeitas que nasceram com pênis, alocando-as na letra "T", como "trans ${ }^{155 ", ~ " t r a n s e x u a i s " ~ o u ~ " m u l h e r e s ~}$ transexuais". Porém, as sujeitas que se reconhecem mulheres não se sentem representadas naqueles espaços de reinvindicação. Quando muito, buscam o apoio dos movimentos de mulheres.

Quando eu voltei da Itália estava meio sem rumo. Recém-operada, não sabia o que fazer e estava esperando sair a documentação (alteração de prenome e gênero nos documentos após ação judicial). Era o auge desses movimentos sociais. Estava tendo um encontro das "trans" num hotel aqui na minha cidade. Então, me chamaram para falar numa mesa. Tinha uma transexual operada de São Paulo, também. Eu disse: mas o que eu tenho para dar, para falar a essas pessoas? Eu só

\footnotetext{
${ }_{155}$ De acordo com um site que promove a cidadania da comunidade LGBTTT o "Dia da Visibilidade Trans é comemorado anualmente no dia 29 de Janeiro". A justificativa para a data seria a "[...]campanha governamental sobre cidadania e saúde para o público de travestis e transexuais, intitulada Travesti e Respeito, através do Ministério da Saúde". Maiores informações:

http://www.grab.org.br/index.php?option=com content\&view=article\&id=210:grab-e-abglt-celebramdia-da-visibilidade-trans-em-fortaleza\&catid=32:home\&ltemid=44

Último acesso em: 01/05/15.
} 
posso falar da minha experiência, não posso falar de movimento social, o que tem nele, como é organizado... É meio que um pouco simbólico, um corte simbólico: você se operou, corta o vínculo com essa coisa de "trans". Você apaga da sua vida essa palavra. Depois do evento, fui convencida por algumas militantes a trabalhar em uma ONG: - "Fulana, você fala tão bem! Tem uns projetos para tu coordenar que vai vir verba do estado". - "É só apresentar o projeto e tá prontinho!" Eu desempregada, ia ganhar um salário... Estava meio perdida, né? Então, olhei o projeto, mudei algumas coisas e mandei. O projeto foi aprovado, saiu o recurso e lá fui eu para as ruas, entregar preservativos para as profissionais [do sexo]. Eram todas travestis mesmo. O problema é que eu não tinha acesso às contas. Eu era coordenadora só no papel e na ação. Passaram por uma auditoria nessa ONG. Prestei contas direitinho do meu projeto. Mas a ONG estava cheia de irregularidades. Os dirigentes estavam usando notais fiscais de coisas que nunca existiram. Foram ver que o dinheiro estava todo empenhado na casa da presidente da ONG. Eu rompi com eles porque percebi que não dava futuro. Depois, em um grupo virtual, eu colaborei com algumas ações de um projeto de mulheres como eu e foi bom. No final das contas, ia fazer projetos para quem? Essa população que a gente conhece, não é a população "t", "transexual". E eles [o governo] queriam projetos. Mesmo que parecem ser um grupo coeso de pessoas, as representações são muito diluídas. Não tínhamos onde buscar gente para compor comitês, militar, essas coisas. Chegamos à conclusão que não são demandas de grupos, mas de pessoas.

\section{O problema transexual.}

Para a interlocutora, o que se nomeia como "transexualidade" ou o problema "transexual" não é algo fixo, mas um "contexto" ou um processo cujo término seria a adequação cirúrgica da genitália. É um falso problema, na medida em que a busca é pela cirurgia e não por ser "transexual". A necessidade ou o desejo pelas cirurgias é a demanda principal para a completude da identidade 
feminina e de mulher ${ }^{156}$. Entretanto, para ela ser "transexual" é muitas vezes um obstáculo à realização desse objetivo.

Até o momento da cirurgia eu entendia que o transexual, a palavra "transexual", iria caber, até aquele momento. Então, eu aceitava a palavra transexual, aceitava o conceito da transexualidade. Acreditava estar nesse contexto da transexualidade. Mas acreditava que tinha uma finitude. O momento da cirurgia é como se fosse um... (pausa)Se é uma síndrome, distúrbio de identidade de gênero, eu via a cirurgia como o remédio para a cura dessa síndrome. Então, eu vou deixar de ser! O meu choque foi saber que mesmo depois da cirurgia eles querem te colocar naquele contexto, eles querem te enquadrar como uma "t" naquele quadrado lá. Ou querem fingir que você agora tá naquele quadrado lá e você antes não estava, o que é o pior! Eu entendia que "transexual" é uma mulher com um probleminha a ser consertado. Mas no entender deles não é assim, não! Esse papelzinho, esse rótulo, esse carimbo, esse clichê transexual nunca acaba. Você é transexual, vai fazer a cirurgia e continuar a ser transexual sem pau, sem pênis, sem falo. Para eles é "um outro". Comecei a ter problemas em ser colocada na transexualidade. Quem é transexual aqui? Se estou falando que não sou, devem me escutar. Esse termo é ruim. Não é agradável, não é um elogio, né? É coisa negativa. Se transexual fosse qualidade, estava todo mundo lutando para ser "trans" - "quero fazer prova para ser trans" (risos). Então, para quebrar isso eu já tinha afinidade com a psicologia. Penso que tem que ter uma forma. Tem de ter trabalhos onde as sujeitas possam se definir e essas pessoas, esses "especialistas", têm de se adequar ao que a pessoa está dizendo e não o contrário. Qual quadradinho eu tenho que colocar aqui? Não tem aquele normal, não? Eu quero aquele normal![Questiona-se como quem responde a um questionário no qual ela marcaria a opção "normal”, de mulher, e não de "trans"].

\section{A desnecessidade da categorização.}

Para ela não há justo motivo para a classificação "transexual". A atual categorização médico-psicológica e jurídica produz a submissão da sujeita ao poder

\footnotetext{
${ }^{156}$ Aqui podemos relembrar as discussões de Victor Turner no começo do capítulo sobre a situação de liminaridade nessas questões. No limite, a ideia de transexualidade faria sentido para as sujeitas apenas como condição liminar.
} 
e ao controle de outrem em razão da necessidade ou desejo pelas cirurgias. Como se viu acima, não permite ou acolhe a manifestação genuína da identidade. Assim, a sujeita - quando ciente do jogo de interesses - representa um papel para os "especialistas". Eis um dos aspectos do dilema.

Não há necessidade alguma da categorização da transexualidade. Infelizmente esses peritos, médicos, profissionais, juristas, blá, blá, os "controladores da vida alheia"157, eles se baseiam por parâmetros arcaicos que serão derrubados com certeza. Eu acredito que daqui a vinte, vinte e cinco anos, talvez, nós sujeitas, e todos os sujeitos e todas as sujeitas, vão poder falar sobre si e vai haver milhões de possibilidades. Milhões de categorias ou sem categoria nenhuma, que era o ideal. Mas haverá outros questionamentos. No momento, eles querem ter controle sobre alguma coisa, mas o mecanismo de controle é errado, pois qualquer um pode burlar as categorias. É um modelozinho que qualquer um pode burlar. As informações estão cada vez mais globalizadas. Todo mundo tem acesso. Tem crescido a demanda pelas cirurgias. O que eles definiram que seria o "distúrbio de identidade de gênero" é tão fechado que é fácil de burlar. Eles se enganam achando que vão conseguir identificar tal coisa. Um outro gênero, um homem, um ator pode chegar para eles e interpretar aquele papelzinho - olha como é falho! Tanto não funciona que se vê pessoas vivendo em vidas paralelas, numa sexualidade paralela, numa vivência travesti, por exemplo. Um senhor chega a esses profissionais com a queixa de "sentir-se mulher". Agora em Goiânia mesmo um delegado casado"158, acabou de assumir a Delegacia da Mulher depois de fazer uma cirurgia de mudança de sexo. Eu não estou dizendo que esse cidadão, essa cidadã, seja mulher ou deixe de ser. Mas supondo que a queixa não seja verdadeira... (pausa) No meu entender hoje, agora, sentir-se mulher e ser pai são situações conflitantes! Ser pai vai de encontro a ser mulher. Não dá para ser mulher e ser pai. Se o cidadão procriou com a sua

\footnotetext{
${ }^{157}$ Bruxa Malvada do Oeste define assim essas categorias de gentes: "pessoas que supostamente sabem muito mais sobre você do que você mesma."

${ }^{158}$ Ver matéria em:

http://g1.globo.com/goias/noticia/2014/02/apos-troca-de-sexo-delegada-goiana-consegue-direito-demudar-o-nome.html Último acesso em: 01/05/15.
} 
genitália masculina, na minha concepção, não é possível que seja mulher! Meu pai não é mulher! Meu pai pode até ser um transexual, mas mulher ele não é! $!^{159}$

\section{O acesso às cirurgias tem de mudar.("O que está em jogo é mudar!”).}

No nosso entender os "especialistas" ou "controladores da vida alheia" entendem a demanda pela cirurgia como queixa pela identidade e assim o pedido jamais é atendido. Nos argumentos da Bruxa Malvada do Oeste percebe-se que nem sempre é dessa forma.

A gente precisa se submeter. É o que tem hoje. Quero fazer a cirurgia, não vou poder fazê-la sozinha, me anestesiar, me operar e depois me representar juridicamente. Com certeza esse modelo é errado. Não tem sentido algum. O ideal seria você ir e expor, mostrar quem você é. Talvez possa haver critérios mínimos para ter acesso às cirurgias sem passar por uma categoria médica como transexual. Essa sujeita que se classifica como mulher, mas que precisa de uma redefinição de sexo, pois nasceu com uma genitália com a qual não se identifica. Tem de ter uma escuta mais atenta, para saber o que de fato ela quer: - "É assim que você quer?" "Como posso encaminhar sua queixa?" Porque se veio pedir socorro é porque não está satisfeita com alguma coisa. Vamos definir o problema de forma que ela não se sinta agredida na sua dignidade, na sua essência. O que está em jogo é mudar! Abrir aquilo ali para a possibilidade de mulheres ${ }^{160}$ serem contempladas. Ouvir as sujeitas, principalmente isso, e aceitar. Não só ouvir: - "Ah! Ela não sabe do que está falando! Ela tá achando que sabe, mas não sabe. Eu que sei!" Isso é falho, é pretensioso! É soberba demais de uma ciência afirmar a tua história por você. Se hoje alguém disser: - "Eu sei que não vou ser feliz fazendo a cirurgia, mas eu quero fazer". Eles vão negar. A busca da autorrealização da felicidade é a felicidade! Você não vai fazer a cirurgia e ser feliz! Você vai sempre buscar alguma coisa. Somos seres em busca, seres faltosos. Antes da cirurgia há que se reconciliar-se com você

\footnotetext{
159 Esse trecho da fala de Bruxa Malvada do Oeste nos faz refletir no sentido inverso das entrevistadas do trabalho. Por essa perspectiva, nem todas as sujeitas que passam pela cirurgia de adequação genital poderiam se identificar plenamente como mulheres, mas ao contrário das interlocutoras, poderiam ser transexuais. Consequentemente, essa hipótese indica também que nem sempre o que se nomeia por "transexualidade" é uma condição liminar. Para algumas pessoas pode ser perfeitamente uma identidade.

${ }^{160}$ Ela se refere aqui a "mulheres que nasceram com pênis".
} 
mesma, com a sua imagem, para que a suas faltas próximas sejam sempre simbólicas. Ninguém vai ter uma vagina simbólica. Mas a vagina real tem de suprir uma falta simbólica. Se a minha necessidade é que a sociedade me veja como mulher não vai ser a vagina que vai preencher essa minha falta. Primeiro tem de ser aquilo que você vivia antes. A tua falta física da vagina é para dar continuidade do seu ser, o que é do teu ser! Você não tem como dar conta do próximo, da coletividade!

\section{Só você sabe de você mesma.}

Eu acho assim impossível que uma pessoa ache que sabe mais de você do que você mesma. Como que aquele cidadão ali na esquina, sei lá, um profissional, em seu nome pode saber de ti? Está entendendo? Você que vive, que sabe dos seus anseios, dos seus problemas, das suas mágoas, dos seus desejos, das suas frustações, de ti. Como que essas pessoas podem definir a tua vida? Se tu pode ou não fazer. Está entendendo? Porque a impressão que passa é que se eles não autorizarem você não vai fazer (se operar). Não, você não pode fazer, porque ninguém quer se responsabilizar... Tá entendendo? É uma coisa assim incrível... Quem que pode ditar o que você é senão você?! Eu falei: - "Eu vou ser psicóloga para contestar". Porque só pode contestar, eles só vão ouvir, no campo deles. É humilhante!

\section{Bruxa Malvada do Oeste fala de si mesma. ("E para mim não me faz menos mulher não parir").}

Relaciono-me com as pessoas, acredito eu, como mulher. Como sou: mulher. Se eu me sinto mulher?!? Não reflito sobre isso, mas eu acho que sim. Eu sou mulher! Sou vista e reconhecida como mulher! Logo após a cirurgia eu tive uma perda. Pensava: mas que mulher que sou? E que mulher que eu era? Eu não era mulher e agora eu sou? Teve essas quebras assim. Hoje não vejo diferença alguma em relação a uma mulher nascida com vagina. Vou comparar entre mim e minha irmã. A única diferença é que ela menstrua e eu não, a questão física. E a questão biológica. Mas, parir é de ser fêmea, é biológico. O ser mulher é algo que é construído. Ser mulher e 
parir são duas coisas diferentes. Respeito... Não tenho inveja de quem pare. Já tive, não tenho mais. Tem mulher que se realiza sim. Preenche, é saudável, é legítimo. Depois, o filho cresce e vai preencher com outra coisa (risos), porque o filho não vai ficar para sempre, o filho é para o mundo. Não vejo diferença absoluta, nenhuma, nenhuma. Nesse sentido, biológico, é a única diferença e para mim não me faz menos mulher não parir. Não me faz menos mulher porque eu sou uma mulher que não quer ser mãe. Se eu fosse uma mulher que quisesse ser mãe, como já quis. Já fui uma mulher que quis ser mãe. Eu seria mãe sem parir. Tem muita mulher que quer ser mãe e não quer parir. Uma amiga falou esses dias: - "Eu quero muito ser mãe, mas não quero parir. Eu quero adotar, porque tem muita criança que precisa e tal". Ela colocou isso num contexto e ficou muito bacana.

\section{"Sempre tem alguma coisa que você quer mudar."}

Essa parte da genitália está superada. Se você perguntar para qualquer outra mulher: - "Você está feliz com seu corpo, consigo mesma?" Você vai encontrar queixas. Sempre tem alguma coisa que você quer mudar. Todas querem ser mais baixas, mais altas, cabelos mais cacheado, mais liso e tem as facilidades para isso. A paz com o corpo, com a imagem, é uma quimera! Vai sempre haver uma inquietude. O saber lidar com a inquietude, respeitando as tuas questões. Por exemplo, a questão cronológica... Eu acho uma perversão as pessoas não quererem envelhecer (risos). Colocar isso é importante. Temos que envelhecer. Como não? Ninguém vai ser eterno. Imagina se não tivesse a finitude?! Se eu não soubesse que um dia eu ia morrer, quando eu ia fazer a cirurgia? "Ah, vou esperar no dia que vai dar". A ideia de finitude é importante!

A paz interior psicológica, afetiva, essa subjetividades, elas serão saciadas. E novamente voltará a faltar alguma coisa e serão saciadas num ciclo que só terá fim com a morte. A questão de uma necessidade visível e aceitada por todos é mais importante. Por exemplo, uma criança com lábio leporino. Causa muito sofrimento, é visível, há uma melhoria de vida e eu comparo muito com isso. Nesse sentido, não ter pênis é maravilho. Ter a vagina, essa pseudovagina, clinicamente, uma pseudovagina, já me conforta, me deixa muito feliz. Não tenho viagens. Porque a questão física não é mais importante que a queixa psíquica. Se eu fosse acreditar 
que essa vagina me fez mulher, então eu não sou mulher porque não estou menstruando, então eu não sou mulher porque eu não vou pôr uma vida no mundo ${ }^{161}$. É importante que fique bem claro na cabeça da cidadã. Porque se ela achar que vai ser mulher depois da cirurgia é melhor não fazer.

\section{Bruxa.}

Embora se defina como bruxa, praticante da Antiga Arte, Bruxa Malvada do Oeste neste momento não está atuante nos rituais ou na busca filosófica dessa temática. Por ora se dedica às questões práticas da vida. Por outro lado, o lugar da magia, entendido como a expectativa de uma mudança radical na visão social acerca da sua identidade, parece ser menos atuante na atualidade, se comparada às demais sujeitas.

A última coisa que eu quero pensar é em algo potencialmente religioso. Não que eu me negue como Bruxa. Acho que sou Bruxa. Acho, não, sou Bruxa! Mas é algo que no momento quero adormecer. Quero pensar na parte prática. Os rituais que eu ainda gosto são os de olhar a Lua. Contemplar a Lua. Não que eu vá fazer um banho mentalizando alguma coisa, ou me preocupar com a energia das pessoas. Até porque eu criei um campo protetor onde estou barrando tudo. Não me deixo mais influenciar tanto. Não me entrego no sentido de ser íntima de alguém. A não ser de alguém que eu já tive uma história. Estou tentando manter e cultivar as coisas que eu fiz até aqui. Neste momento não quero relações novas. Estou me preservando. Estou concentrada nos meus afazeres.

\section{As descobertas acadêmicas e as perspectivas de futuro.}

A interlocutora cursa $03^{0}$ período da graduação de psicologia numa universidade federal da localidade onde vive. A vida acadêmica tem propiciado novas descobertas, novos estudos, caminhos diferentes. Estudante inquieta, faz uma leitura crítica dos autores tidos como clássicos na psicologia e psicanálise.

\footnotetext{
${ }^{161}$ Com essa reflexão, a interlocutora alerta para as diferenças e similitudes entre gênero, sexo e identidade. Nas demais interlocutoras pretende-se fazer um esforço em diferenciar melhor essas dimensões.
} 
Atualmente, ela desenvolve pesquisa na modalidade PIBIC com escola e comunidade, na área de psicologia social.

Minha principal meta agora é a graduação. Ter a experiência da pesquisa cientifica [PIBIC]. Terminar a graduação e por enquanto vou me limitar a isso. Minha meta maior, eu sou muito ambiciosa, eu quero deixar minha marca numa linha de abordagem da psicologia, da psicanálise. Eu quero trazer contribuições para essa linha. Quero atualizar os pensamentos elaborados por Lacan, na sua terceira tópica: o real, o simbólico e imaginário. Sinto que está faltando algo nessa abordagem. Há conflitos atuais que não existiam naquela época e que podem ser contextualizados numa nova abordagem. Novos sujeitos e sujeitas podem ser inseridos, sem ressalvas, quebrando a rotulação. Freud [Sigmund] eu acho que ele é machista. $A$ forma como ele culpa a mulher no complexo de Édipo, na explicação da professora, é muito mais fácil uma mulher cometer um crime passional do que um homem. $A$ histeria, a parte como ele começou, nada mais é do que uma inquietude da mulher por querer um futuro diferente daquele a que estava predestinada. As mulheres cultas, estudadas, segundo ele, deveriam ser educadas para serem "vendidas" com algo a mais, lapidadas. Quando você estuda você abre a sua mente. Você passa a olhar as coisas de outra forma. Mulheres que almejavam um cargo, outros patamares, eram as histéricas para ele e isso é errado!

\section{As mulheres não sublinhadas, sem negrito e sem aspas!}

Espero concluir a graduação, fazer mestrado, doutorado. Prestar concurso público. Ser alguém. Escrever livros. Contribuir cientificamente. Fazer coisas. Depois morrer né? (risos) Para as pessoas que compartilham da minha realidade, eu espero, eu acredito que essas mulheres não serão sublinhadas. Serão mulheres sem negrito, sem aspas. Eu acredito que elas vão construir coisas, vão construir pensamentos, vão dar sua contribuição de um mínimo possível. Nem todas vão seguir carreiras profissionais valorizadas. Eu acredito que até mesmo essas que se dedicarem a uma vida mais simples, a um marido, a um filho adotivo, contribuirão! Foi feita uma tentativa de um movimento político para esse tipo de mulher, né? E se consensuou que seria sublinhar uma população que não quer ser sublinhada. Acho que individualmente elas vão lá construir coisas e tal, sem a necessidade de uma 
visibilização. E essa visibilização se houver não vai ser mulher! Não vai ser essa mulher que sou eu, essa mulher que são umas mulheres que conheço. Vai ser outra coisa. Qualquer tentativa de sublinhar essa mulher será uma tentativa fajuta que não considerará sua identidade. Porque não é possível, pois as identidades são múltiplas.

\section{O que é ser mulher?}

Para mim ser mulher é viver a sua individualidade, suas subjetividades, suas peculiaridades. Vivenciar isso de uma forma sua, sabe? Uma forma sua que você vai criando no seu dia a dia. Assim como talvez possa ser [com um] homem, também. Acho que não tem uma fórmula, o que é uma mulher... Primeiro de tudo, o que é um ser humano? A mulher é um ser humano! E o que é ser mulher na minha concepção, que não é a concepção muito usual. Fala-se uma coisa e na prática é outra. $A$ mulher é ser humano igual ao homem. Que constrói cada dia. Ganha-se muita coisa. Luta-se muito. Nessa conquista houve perdas, nessa trajetória houve perdas. A mulher que eu sou é a mulher que eu não vejo escrita ainda. Não leio sobre ela. Não vejo escrita, não vejo retratada, não vejo... Então, fica difícil encontrar esse ser mulher que sou eu. Vamos criar isso! Talvez, no futuro alguém saberá dizer o que eu estou querendo dizer agora. 
Capítulo 3 - Úrsula - a Feiticeira do Mar.

"Não tenho como ser outra mulher! Eu sou a mulher que eu sou.

Para mim basta. Ponto. Fim!"

Não tem como ser comparada com transexual porque não sou (risos). Não sou! Como é que vou ser comparada? (risos) Na parte biológica, tudo bem. Porque vai transgenitalizar. Mas não tem como. Por mais que minha cara diga, que meu corpo diga, que esteja escrito ali. Eu não sou. Pronto! (risos) Não sou pra mim, não vou ser para os outros. - "Ah, porque ela é meio doidinha..." - Já me disseram: - "Ela é meio doidinha porque ela não aceita... Ela não aceita a transexualidade dela!" Como assim? Como é que eu vou aceitar uma coisa que não sou? (gargalhadas) Eu sou mulher e pronto! [...] Eu sou a mulher que sou. Não quero ser a supermulher! (risos) Eu sou uma mulherzinha assim, simples, humilde. A mulherzinha assim do jeitinho que eu sou. A mulherzinha simples, amando com o coração do jeito que eu amo. Porque eu não vou mudar. Transgenitalizar sim; transexual, não! Transgenital, sim! Transexual, não!

O trecho acima é de autoria de Úrsula - a Feiticeira do Mar. Natural de Porto Alegre/RS reside atualmente com o marido num pequeno apartamento em uma das cidades do estado de Santa Catarina/SC. Quanto à educação formal, a interlocutora possui ensino médio completo. É costureira desde menina, trabalhando hoje numa pequena confecção na cidade. Igualmente é artista, mais precisamente cantora lírica, portadora de uma possante voz de amplitude mezzo-soprano. Os afazeres domésticos, os cuidados afetuosos com o marido e o trabalho tomam boa 
parte do seu dia, porém aos poucos retorna às aulas de canto, preparando-se para estrear um show musical em que homenageará algumas cantoras da era do rádio, inclusive Carmem Miranda. Aos 41 anos já passou por diversas situações de violência, discriminações, dores, indignações. Entretanto, uma das mais aflitivas é a longa espera pela cirurgia que já dura quase seis anos. A fé em Deus, nos cultos aos antepassados e nas orações da Igreja Messiânica Mundial ${ }^{162}$ a ajudam a enfrentar a espera.

\section{Conheci Úrsula - a Feiticeira do Mar quando acompanhava Malévolaa} uma das intermináveis consultas de terapia de grupo no Hospital de Clínicas de Porto Alegre, na cidade de Porto Alegre/RS, em 2012 ${ }^{163}$. Assim como diversas outras moças postulantes às cirurgias ${ }^{164}$, ela estava sentada nas cadeiras de espera conversando animadamente sobre diversos assuntos, dentre eles, os resultados cirúrgicos, as expectativas de funcionalidade e formato estético das vaginas.

Numa das falas, a posição diferenciada sobre o que se chama de transexualidade, chamou-me a atenção:

Porque na essência, pra mim, não muda nada! Não fico pensando se a vizinha está pensando se eu sou isso, sou aquilo. Então essa coisa de transexualidade, mudança de sexo, nada! É uma adaptação do teu interior. Da naturalidade, da descoberta, da permissão de ser quem você é. Na descoberta de quem você é, também. Não vejo como mudar o meu sexo. Nunca vou mudar meu sexo. Eu sou mulher e pronto. Não tem como mudar meu sexo. Vou mudar para ser homem? Não tem como ser homem!

\footnotetext{
$162 \mathrm{Na}$ edição $n^{\circ} 77$ (junho/julho de 2014) da revista "Izunome", publicação da Igreja Messiânica Mundial do Brasil, um dos mais célebres autores daquela fé, Meishu-Sama diz que o princípio orientador da religião é "[...] o ideal de uma nova civilização". Para tanto, as atividades ou missões da igreja são: "[...] no plano individual, consiste em salvar o homem da pobreza e contribuir para sua saúde física e mental; no plano social, sua finalidade é construir uma sociedade sadia e pacífica." (2014: 5). Maiores informações: www.messianica.org.br.

${ }^{163}$ Como dito anteriormente, faz parte dos protocolos de atendimentos com vistas à autorização para a cirurgia, frequentar assiduamente as sessões de terapia de grupo. Em determinada fase, é preciso se consultar com a assistente social para averiguar a "rede de apoio" que a sujeita dispõe. Acompanhei, com recursos próprios, Malévola a um ou dois desses encontros na condição de "testemunha" de que ela se identificava como mulher, precisava da cirurgia e terá suporte quando a fizer. Nos protocolos do HCPA ao menos um parente, familiar ou amigo íntimo precisa estar presente juntamente com a "paciente" nos encontros com a assistente social.

${ }^{164}$ Embora haja um clima de ansiedade e espera, as postulantes nomeadas como "pacientes" driblam a hostilidade do ambiente médico com roupas, maquilagens, sapatos de salto, adereços - tudo muito colorido e alegre - em mais um dia de performances para a plateia formada pelos "especialistas da vida alheia". Nos sorrisos e olhares, parecem zombar dos critérios canônicos. O respeito ao sofrimento alheio é rigorosamente mantido no volume baixo dos sons das conversas.
} 
Devidamente apresentadas, pude conhecê-la melhor e ouvir um pouco sobre sua trajetória, partilhando igualmente minhas percepções sobre esse tema. Perguntei-Ihe se se importaria em ser entrevistada por mim. Expliquei sobre o trabalho, sobre o enfoque inédito do tema. Ela concordou em ser escutada, desde que pudesse manter $\mathrm{o}$ anonimato dos dados pessoais, modificando também algumas partes da história para não ser identificada. Depois de alguns meses de conversas telefônicas, em novembro de 2014 passei três dias com ela e seu esposo.

Bruxa do mar ou Feiticeira do mar ${ }^{165}$ é uma das personagens do conto infantil "A pequena sereia" de autoria do dinamarquês Hans Christian Andersen $(1085-1875)^{166}$.Em 1989, na adaptação para o cinema em formato de desenho animado realizada pelos Estúdios Walt Disney, ao contrário da obra original, os personagens ganham nomes. A protagonista, "Sereia Ariel" tem o sonho de se tornar humana para casar-se com o príncipe e "viver feliz para sempre". Busca então a ajuda de "Úrsula", a bruxa do fundo do mar, que prepara uma poção para a realização do sonho, em troca exige-Ihe seu bem mais precioso: sua linda voz. Mas além das diferenças entre seres do mar e humanos, na resistência do pai, a sereia terá de lidar com a fúria da bruxa Úrsula, enganada pela protagonista ao final. No original, a Feiticeira do mar, adverte à Sereia sobre as ilusões do sonho de se tornar outra criatura apenas pelo amor de um homem:

"É uma tolice muito grande da sua parte, mas você terá o que deseja, e isso Ihe trará muitas aflições, minha linda princesa. Você quer se libertar de sua cauda de peixe, e substituí-la por dois suportes, como os seres humanos da terra, para que o jovem príncipe possa se apaixonar por você, e para que você tenha uma alma imortal. [...] você sentirá muita dor, como se estivesse sendo atravessada por uma espada. Mas todos os que a olharem, dirão que você é a mais linda criaturinha humana que eles já viram. Você manterá ainda a mesma delicadeza de seus movimentos de flutuação, e nenhuma dançarina poderá caminhar com tanta leveza, mas a cada passo teu você sentirá como se estivesse pisando em facas afiadas, e que o sangue precisa fluir. Se você conseguir suportar tudo isto, eu poderei te ajudar.[...] Mas pense direito [...] pois quando o seu corpo assumir a forma de um ser humano, você não poderá mais ser a pequena sereia. Você jamais retornará através da água para junto de suas irmãs, nem para o palácio de teu pai

\footnotetext{
${ }^{165}$ Disponível em: http://pt.wikisource.org/wiki/Contos de Andersen/A pequena sereia Último acesso em 12/05/15.

${ }^{166}$ Disponível em: http://www.infopedia.pt/\$hans-christian-andersen Último acesso em 12/05/15.
} 
novamente, e se você não conquistar o amor do príncipe, de tal modo que ele esteja disposto a esquecer pai e mãe por tua causa, te amar com toda sua alma, e deixar que o padre junte suas mãos para que vocês se tornem marido e mulher, então, você nunca terá uma alma imortal. Na primeira manhã depois que ele desposar outra mulher o teu coração irá romper, e você se tornará espuma na crista das ondas." (idem) ${ }^{167 "}$

O conto original alerta para o perigo da perda da essência, o abandono e o sacrifício das qualidades reais, por um objetivo, digamos, romântico. Talvez diga até sobre o desapego da infância e da fantasia, as dores do amadurecimento, a presença da morte. No fim, a Pequena Sereia não se casa com o Príncipe, nem vive feliz pra sempre. Mas seu sacrifício, aos olhos do autor, não teria sido em vão, pois ela adquire a alma imortal tão almejada por todos, torna-se um espírito, uma brisa, a aliviar o calor dos seres humanos.

Atentando-se para a fala da Bruxa do mar do conto de Andersen, a interlocutora ${ }^{168}$ sabe que terá de sangrar e que haverá passos sem volta. Porém sabe também que os anos perdidos e o bisturi do cirurgião não mudarão sua essência. Tem ciência de si suficiente para fazer escolhas que levem aos objetivos não de forma impensada ou romântica, mas profundamente refletida. Sabe que a transformação do corpo é necessária - inclusive para a manutenção da essência porém sem expectativas irreais consigo mesma e com os outros. Lida com o jogo de saber-poder médico-jurídico, naqueles ambientes, com certa facilidade:

Não me importa se me obrigam. Ninguém me chama de transexual. [na vida quotidiana] Mas tem de dar um nome. E se eu tiver de carregar esse nome lá dentro [do hospital] como transexual para obter mais uma adequação na qual eu me sinta a mulher que eu sou, pra mim ótimo! maravilhoso! Tanto que eu sou a primeira a dizer: não precisa mudar a identidade agora. Muda depois. Não tem grilo! Eu sou mulher mesmo. Se quiserem me chamar de outra coisa, podem me chamar!

Novamente, assim como aconteceu com a Bruxa Malvada do Oeste, as perguntas se mostraram insuficientes, pois as lembranças, nas cenas de vida, são

\footnotetext{
${ }^{167}$ Disponível em: http://pt.wikisource.org/wiki/Contos de Andersen/A pequena sereia Último acesso em 12/05/15.

${ }^{168}$ Apresentei-Ihe a sugestão de identifica-la no trabalho como Úrsula, pois essa entrevistada, além de usar a voz, se identifica com o mar e seus mistérios mais profundos. Ela achou a ideia muito boa.
} 
evocações vivas dos momentos. Responder simplesmente a uma pergunta não fazia o menor sentido. Então, decidimos tentar reproduzir as memórias passadas. As reflexões de Úrsula - a Feiticeira do mar serviram para delimitar os temas.

Assim, logo de início, admite quando perguntada sobre "transexuais", que essas pessoas podem de fato existir:

E será que isso não existe para algumas pessoas? Eu não tenho como viver o que os outros vivem. Eu tenho como falar de mim. Eu tenho como ser eu. Eu sei ser eu. Eu não me enquadro num conceito de que seria do grupo macho porque não tem como.

E nesse espírito segue-se o trabalho: sem pretensão alguma de encontrar uma universalidade de pessoas que se sentem, expressam-se, falam de si do mesmo modo.

Ou encaixam-se como "transexuais":

Essa coisa de transexual (tom de deboche). - "Porque você é isso!" Tudo bem, quer chamar disso aí? Você entende assim? Tudo bem! Não, mas tenta viver dentro de mim. A minha verdade não é a verdade absoluta para todas as pessoas! A minha verdade me basta e pronto! Fim! Ponto! Eu sei de mim. O juiz lá vai botar na minha carteira de identidade - "Ah, ela é transexual"?! Não aceito isso! Não aceito isso! Não fiz o que a sociedade pediu? A medicina vai lá transgenitalizar e pronto! Só troca o nome e grande coisa! Qual o problema?

Necessário também problematizar mais uma veza "ilusão", o fôlego bibliográfico, que uma dissertação como essa poderia suscitar nos leitores. A interlocutora e eu nos conhecemos há pouco mais de dois anos. Moramos em cidades distantes e nos vimos pessoalmente menos do que gostaríamos. Hoje nos consideramos amigas, porém a proximidade afetiva não nos permite afirmar seguramente que nos conhecemos profundamente. Tão pouco tenho autorização para descrever uma narrativa que pretensamente retrataria todos os momentos da vida da interlocutora. Dessa vez, escrevi o capítulo sozinha. Ela teve acesso apenas depois de pronto, não desejando modificar nenhum trecho.

Assim, como as demais interlocutoras, não se trata de biografar os fatos importantes da vida da Úrsula -A Feiticeira do mar, mas selecionar, dentre os temas recorrentes nas conversas que tivemos, os mais enfatizados, pois são afeitos ao tema do trabalho. Entretanto, ela não faz muita questão de relembrar o passado: 
Esquece o passado! Fim! Eu já tenho a bagagem de carregar um corpo que é uma coisa meio complexa. Ainda ficar relembrando, revivendo. - "Ah por que eu fui daquele jeito?" Eu não pude viver de outro jeito. Eu revivi toda essa dor. Toda a infelicidade que eu tinha comigo.

Como dito acima, a presença da fé religiosa é na atualidade um dos grandes apoios para que essa sujeita consiga suportar a longa espera pela cirurgia que gira em torno de seis anos. Atualmente, ela frequenta diariamente as liturgias prescritas pela igreja Messiânica. A fé abnegada em Deus dá sentido ao sofrimento, pois a cirurgia será um presente:

Eu mereço esse presente de Deus. Eu mereço esse presente de Deus, né? Uma boa recuperação, Uma boa alegria!

Algumas vezes, Úrsula - A Feiticeira do Mar sofre preconceitos e discriminações:

Eu faço leitura labial. Às vezes de longe uma pessoa olha para outra e diz: - "Mas ela não é mulher." Eu vejo a leitura labial e eu digo, penso para mim: "Para você (ênfase em "você") eu não sou!" E não tenho como mudar os traços masculinos que o meu corpo me deu. Eu sou uma mulher para mim! Na minha luz!

Em outras: violências e humilhações até nas mínimas necessidades humanas:

E me tiraram aos berros e puxões. Eu fui falar com os superiores e me disseram assim: - "Mas tu pensas que és o que? Tu és um putão, tu és um viado. Tu não podes frequentar o banheiro feminino!" Assim, desse jeito. Nesse tom. Não consegui fazer xixi, fui tirada para fora. Fui falar com os superiores. Já não aguentava mais de vontade de fazer xixi. Necessidade, né?

[...] Eu me mijei e me caguei dentro do shopping. Não segurei. [...] Eu cheguei na minha casa completamente fedorenta, apavorada, horrorizada e triste com toda essa situação que eu não precisava nem ter passado por isso. Não precisava ter passado por isso.

[...] Humilhante ao máximo!

Porém, sempre há espaço para realizar os sonhos. A costureira desde menina é artista. Adulta, ganhou diversos concursos em que performava na pele da 
cantora Carmem Miranda ${ }^{169}$. Nos palcos, sob as luzes, diante da plateia, figurinos e maquilagem precisos, ela encontra a felicidade:

É a minha vida! Meu sonho, antes de ser costureira, meu sonho era cantar, dançar e representar, alguma artista, alguma coisa...

Com o marido compreendeu o significado de entrega total: mente, corpo, emoção, instintos. O toque mágico e sem explicação. Mas durante boa parte da vida em razão do pênis não se permitiu relacionar-se mais intimamente com os homens ${ }^{170}$. Situações corriqueiras na vida de muitas pessoas, como as descobertas afetivas da juventude, não puderam se realizar:

Não pude viver na minha adolescência os beijos virgens que qualquer menina pode dar. Que seria meu sonho. Porque meu corpo me impediu disso. De exercer simplesmente a minha essência. Hoje vejo que me faz falta. Eu não vivi isso. Eu gostaria de ter vivido. Hoje vivo com meu marido coisas que me permito viver, nas quais não vivi com 15, com 18, com 20.

Essa Feiticeira do Mar ainda não alterou o prenome ou o gênero nos documentos oficiais. Disse que fará tudo "num pacote só" após a cirurgia. Contudo, reconhece que ter de apresentar os documentos civis com o nome de nascimento:

É chato porque você se lembra de uma coisa chata. Que eu não gosto de conviver, porque não sou eu. Porque eu não sou um documento. Deram-me um nome, sim. Coitados! Não sabiam, também. Não vim com manual de instrução: - "Olha ela é diferente. Ela nasceu com aquele corpinho ali, mas ela é igual a uma outra mulher. Mas ela tem aquele corpo ali. Isso vai ser a batalha da vida dela!". Não nasci com essa bula, não vim com uma bula de remédio, entende? Não vim com uma bula.

A mulher sem bula, segundo ela, "vai descobrindo a tal bula. Você vai escrevendo a sua bula com o tempo". Na visão da Úrsula - A Feiticeira do Mar, as sujeitas que buscam as cirurgias e se acreditam mulheres "não têm bula", porque ao nascerem não foram identificadas prontamente como meninas. Assim, à medida que crescem tornam-se autoras das próprias vidas e escolhas. Expressam como querem

\footnotetext{
${ }^{169}$ Para saber mais sobre a vida dessa artista singular, Carmem Miranda, veja o site oficial em: http://www.carmenmiranda.com.br/ Último acesso em: 12/05/15.

${ }^{170}$ De um modo geral, diversas sujeitas relatam essas dificuldades antes das intervenções cirúrgicas. No capítulo de Malévola se verá um exemplo de realização afetiva e sexual antes da cirurgia.
} 
ser vistas, acolhidas e tratadas, embora nem sempre sejam vistas ou reconhecidas como de fato são ${ }^{171}$.

Poderíamos pensar: “mas qual mulher nasce com bula?” Estabilizam-se tanto os sexos/gêneros e os papeis relacionados a cada um daqueles que não se percebe que todas as mulheres com ou sem vagina ao nascer viemos sem bulas. Nessa inteligente maneira de pensar, não somos seres passivas diante das famílias, da sociedade, do mundo. Somos sujeitas protagonistas, narradoras das nossas vidas, com modos específicos, pessoalíssimos, de (auto)compreensão. Se a bula for sinônimo de "destino", melhor redigir a nossa enquanto vivemos, ao invés de ter uma antes mesmo de nascer. Afinal, para que servem as bulas?

Úrsula então espera que num futuro, as mulheres de fato (que nasceram com pênis) possam ter acesso às cirurgias e outras modificações corporais e jurídicas bem mais cedo:

Desejo que haja uma definição mais detalhada. Uma descoberta mais antecipada para essas meninas. Um auxílio mais antecipado e preparado, para que não sofram tanto. Porque estou com mais de quarenta e não fui operada ainda.

[...] E isso seria bem cedo, com 13 (anos de idade), tá? Com 12! Evitam-se vários sofrimentos assim.

O incômodo com o pênis vem de longa data: desde a infância. Embora se considere mulher mesmo antes da adequação, o pênis sinaliza para outrem um estágio intermediário ${ }^{172}$.

Porque muitas vezes já chorei por ter um certo desgosto de olhar uma região do meu corpo que eu não gostaria que fosse dessa maneira. Não gostaria.

\footnotetext{
${ }^{171}$ Recentemente uma matéria veiculada mundialmente intitulada "Transgênero de 13 anos recebe tratamento hormonal para frear puberdade e gera debate nos EUA" narrava a trajetória de uma menina "que nasceu menino, mas se identifica como menina" nomeando-a como "transgênero". Destaque para as afirmações da menina sobre si: "Eu sou uma garota. Pareço uma garota. Meu coração é de uma garota", em detrimento aos termos usados pelos médicos: "transgênero", "transexual". O ponto de vista da menina sobre sua identidade não se encontra ao dos médicos e "especialistas", fazendo parecer que se trata de pessoas distintas. Ver em:

http://www.bbc.co.uk/portuguese/noticias/2015/01/150113 trans puberdade lk

Último acesso em: 12/05/15.

${ }^{172}$ Aqui cabe relembrar o capítulo anterior na trajetória de Bruxa Malvada do Oeste e a situação liminar.
} 
Porém o corpo não a limita. Independentemente da materialidade, do dado físico do corpo, ser mulher, no caso dela é questão de essência. Essa essência não é o mesmo que essencialização. Não se trata de um feminino atávico ou modelo de mulher limitado tão combatido há anos pelos movimentos feministas, mas daquilo mais profundo nela. Um lugar mental, emocional, energético ou anímico, uma força vital individualizadora.

Mas eu não posso abandonar minha essência se eu tenho uma reposta de que sou feminina e não preciso fazer força.

Falando-se em feminismos ou referenciais teóricos e epistemológicos feministas que denunciam as relações de poder e subjugação, relações essas rechaçadas ou não mais desejadas pela maioria das mulheres na atualidade, necessário refletir-se e compreender as posições divergentes da teoria na vida concreta das sujeitas, entendendo que a libertação dos modelos/papeis femininos vigentes não pode ser algo imposto, obrigatório, nem invadir a esfera de agência, ao se sugerir que aquelas mulheres "não sabem o que é o melhor para elas".

Os feminismos, em sua proposta de pluralidade de escolhas de vida, devem compreender e acolher as decisões das mulheres sejam elas quais forem e não apoiar-se em postulados pretensiosamente "revolucionários"173.

E não vou jogar pedra no mundo porque insistiu em ver essas questões da maneira que vê. Não vou, né? Porque a mulher que eu sou nem é para isso. Nem está nesse nível ali. De querer bater de frente:- "Vou mudar o mundo à superwoman?" (irônica) Não! A mulherzinha assim do jeitinho que eu sou, tá bom!

[...] Por mais que as pessoas digam: - "É uma mulher diferente!". Não, eu não sou uma mulher diferente! Meu corpo foi diferente. A minha grande libertação foi perceber que eu não sou diferente: eu sou igual a todas as mulheres. Por mais que as pessoas, o mundo, uma parte do corpo me disser que eu sou diferente, eu não me sinto diferente. Eu me sinto igual. Isso me tranquiliza.

Retomando o tema da espera pela cirurgia no Sistema Único de Saúde (SUS), Úrsula - a Feiticeira do Mar tem diversos sentimentos. Em alguns momentos crê que deve se resignar diante das exigências dos protocolos médicos (sobretudo

\footnotetext{
${ }^{173}$ A exemplo do primeiro capítulo deste trabalho, que procura enfocar o problema visto por terceiros, na seção que aborda os fetiches acadêmicos e dos movimentos LGBTTT no desejo insano de encontrar a "TransRevolucionária" nas sujeitas sem que seja essa a vontade delas.
} 
pela fé religiosa), pois o longo tempo de submissão causa(va)-lhe angústias e ansiedades. Essa é a estratégia da resignação.

Então, eu vivo a espera cada vez com mais aceitação, resignação. Fazer desses momentos algo bom, porque eu não quero me prejudicar. Eu não quero viver em neurose. Mais neurose do que é o problema. Tento ser minha amiga. Aceitar isso [a espera] como uma dádiva de Deus. Um desafio ou algo que eu tenho que esperar.

[...] Não quero que isso me incomode! Porque quando eu cheguei lá estava mais incomodada, porque eu queria logo. Eu queria logo! Eu queria com pressa (exasperada).

Noutros, rebela-se refletindo se deveria buscar a cirurgia por meios financeiros próprios. Esse é o caminho da resiliência.

Estou esperando porque eu quero. Porque eu poderia mover um mundo inteiro e pagar uma cirurgia, né? Mas a cirurgia já está paga com meus impostos, né? Ou me pergunto, até onde tenho de passar pelos exames, para minha segurança...

Apesar de tanta dor e sofrimentos, ela não lamenta muito. Na sua filosofia de vida não há espaço para lamentações. Apenas aquilo que não tem solução a faz triste. Se há energia e coragem para seguir em frente há motivos para viver:

Mas enquanto há contornos, retornos, retoques, vamos continuar. Vou continuar... Vou continuar sim!

E quanto ao futuro, essa Feiticeira deseja apenas envelhecer com saúde e beleza (“a beleza das coisas para mim é fundamental”).

\section{Discussão teórica: gênero, sexo, prática sexual e desejo na identidade de Butler (pelo direito de ser mulherzinha!).}

Na obra largamente utilizada como referência por acadêmicas feministas e não-feministas - tida mesmo como revolucionária pelas possibilidades de (re)(des)construções dos corpos, sexos, identidades e relações entre os gêneros: "Problemas de gênero: feminismo e subversão da identidade" - Judith Butler (2008) inicia o trabalho com um diálogo teórico entre as propostas de Simone de Beauvoir e Luce Irigaray refletindo que toda e qualquer possibilidade de análise discursiva do gênero limitam e condicionam as experiências e, segundo ela: 
Tais limites se estabelecem sempre nos termos de um discurso cultural hegemônico, baseado em estruturas binárias que se apresentam como a linguagem da racionalidade universal. Assim, a coerção é introduzida naquilo que a linguagem constitui como o domínio imaginável do gênero (:28).

A autora critica o que chama de "metafísica das substâncias" nas ideias sobre as categorias de sexo e identidade e, nessas, busca analisar a continuidade e coerência entre sexo, gênero, prática sexual e desejo nos gêneros "inteligíveis" (o que chama de "identidade de gênero"). Assevera que "a heterossexualização $0^{174}$ do desejo requer e institui a produção de oposições discriminadas e assimétricas entre 'feminino' e 'masculino', em que estes são compreendidos como atributos expressivos de 'macho' e 'fêmea" .Já os seres cujo gênero é "descontínuo" ou "incoerente" criam oportunidades críticas ao expor os limites e os objetivos de controle, disseminando "matrizes rivais e subversivas de desordem de gênero"(: 3739).

Mais adiante explica melhor que a concepção de "o gênero" somente pode significar uma "unidade de experiência, de sexo, gênero e desejo", no entendimento de que o "sexo, em algum sentido, exige um gênero - sendo o gênero uma designação psíquica e/ou cultural do eu - e um desejo - sendo o desejo heterossexual e, portanto, diferenciando-se mediante uma relação de oposição ao outro gênero que ele deseja." Para ela, a coerência ou unidade interna de homem ou mulher, qualquer dos gêneros, exige uma heterossexualidade "estável e oposicional" numa relação de continuidade causal, naturalizada e compulsória. É o que chama de "gênero como substância". Conclui que gênero não é substância, mas expressão performativa, "constituinte da identidade que supostamente é"(: 45-48).

Após esmiuçar o que chama de "atos corporais subversivos", a autora parece nutrir certa admiração por travestis e sua "dupla inversão", quando aquelas/es subvertem as normas de gênero fazendo "paródias" masculinas e femininas, tanto na aparência, quanto no corpo, no gênero e no "eu". Também fazem paródias subversivas às identidades lésbicas: "butch" e "femme" e os "drags" todos performando o gênero. Entretanto, a autora esclarece que a noção de "paródia de gênero" não significa dizer que há um gênero original que as identidades

\footnotetext{
${ }^{174}$ Mais a frente nomeia de "sistema de heterossexualidade compulsória" a "matriz de inteligibilidade" criadora e mantenedora de práticas discursivas e reguladoras das identidades de gênero (: 39).
} 
parodísticas invistam numa imitação, mas que a paródia decorre "da própria idéia de original", "pela fantasia de uma fantasia". Nesse sentido, à "imitação que zomba da ideia de um original" seria para ela mais bem explicado pelo pastiche(: 195-198).

Butler finaliza a obra reafirmando o "status performativo do próprio natural" relevado pelas performances dissonantes e desnaturalizadas. Igualmente, "as práticas parodísticas" têm sido visualizadas apenas pelas lentes da exclusão "aparentemente inevitável dos gêneros marginais do território do natural e do real." Porém, para Butler, tornar-se "real" e encarnar-se "o natural" é uma falha característica de todas as prescrições de gênero, pois são espaços ontológicos essencialmente inabitáveis, nunca alcançáveis. Assim, a ausência das normas de gênero teria o poder de potencializar diversas configurações de gênero, desestabilizando as identidades substantivas, esbulhando "as narrativas naturalizantes da heterossexualidade compulsória de seus protagonistas centrais: os 'homens' e as 'mulheres'”(:210-214).

Como afirmando no capítulo primeiro, não se pretende a negação das fundamentais contribuições dos estudos feministas/de gênero, tão pouco desmerecê-las ou obscurecê-las. Ao contrário, a crítica que se faz é em relação às exageradas expectativas por parte de algumas pesquisadoras e acadêmicas ${ }^{175}$ (dentre elas algumas autointituladas feministas) desejosas de encontrar um "grupo coeso de pessoas", "movimento social uniforme" ou ainda uma figura-símbolo da imagem da "TransRevolucionária" que incorpore os modelos analíticos propostos por Butler e demais teóricas: ser subversiva (e pastiche) o bastante para sacrificar a própria existência na tão esperada "explosão dos gêneros".

Úrsula - A Feiticeira do Mar refere-se a si mesma como "mulherzinha simples e comum". Em alguns trechos, as narrativas são ainda mais explícitas, como quando fala de si como "essência" que pode ser equivocadamente lida no sentido de colocar-se numa posição social que muitas feministas horrorizar-se-iam por considerar representativo da "inferiorização da mulher na sociedade" ou da significativa "reiteração das posições hierárquicas dos gêneros" que algumas sujeitas demandantes de adequação genital promoveriam. Contudo, a interlocutora

\footnotetext{
${ }^{175}$ No primeiro capítulo apresentamos duas pesquisadoras no tema que se baseiam nos trabalhos de Judith Butler para compor suas teses. Ambas se mostram de certa forma desapontadas por suas entrevistadas não "revolucionarem os gêneros" na medida de suas expectativas.
} 
não extrapola a própria vida indicando que é assim que as "mulheres devem ser" ou o "universo feminino é assim mesmo". E ainda que a entrevistada dissesse algo parecido seria apenas uma voz unitária sobre fonte inesgotável de debates, disputas, avanços e recuos, muito longe de consensos.

A despeito da academia "revolucionária do gênero", pessoas e instituições que pretensamente saberiam melhor do que as sujeitas sobre as vidas alheias, Úrsula - A Feiticeira do Mar é como é. Com ou sem contingências, com pouca ou nenhuma agência, vive a vida como pode. Enfrenta inúmeras dificuldades, negocia ou se submete porque necessita ou quer. Sofre violências incontáveis. $E$ tem o direito de ser mulherzinha, mulher comum, essência feminina e o que mais ela quiser.

\section{Cenas da vida.}

Nessa parte do trabalho, dedicamos espaço para que a interlocutora mostre-se mais nitidamente. São memórias compartilhadas surgidas das reflexões sobre determinado tema ou em resposta a perguntas formuladas de maneira que ela pudesse falar livremente, numa tentativa de evocação das emoções. Pois ninguém melhor para narrar a própria trajetória do que a sujeita que a vive.

Ao contrário da Bruxa Malvada do Oeste, Úrsula - A Feiticeira do Mar não quis reviver lembranças do passado ou dar ênfase em alguma fase da vida que médicos, psicológicos, psicanalistas apontam como unanimidade para a descoberta do que se nomeia por transexualidade: a infância. Preferiu discorrer sobre seu atual momento. Se houver alguma justificativa para a recusa das lembranças enfáticas da infância poderia ser o pouco tempo de amizade ou porque deseje pôr fim ao passado. De qualquer maneira, em algumas cenas se pode enxergar Úrsula nas diversas etapas da vida.

\section{A feminilidade sufocada.}

Sentadas à sua mesa logo após o almoço na pequena copa-cozinha, começamos a conversar sobre diversos assuntos, enquanto comíamos a sobremesa 
de ambrosia. Numa das primeiras cenas evocadas, Úrsula - A Feiticeira do Mar se recorda da mãe, sua grande amiga e dos diálogos que ambas têm com alegria:

Minha mãe diz assim: "- Nossa! Que coisa mais engraçada! Atua existência feminina foi tão sufocada e hoje eu aprendo a passar um batom com você. Como é bonito isso!" - A Minha mãe, minha mãe que me deu a vida, que me pariu, né? Então, muitas vezes ela aprende a ser a fêmea que ela não é, que nunca foi, comigo. Olha que coisa mais linda! Claro que minha mãe é vaidosa, faz as mãos, as coisinhas dela. Ela é a fêmea. Mas eu vejo a minha mãe como um grande macho na vida. Porque ela deu a cara à tapa. Ela lutou muito. E pagou o preço! Eu ganhei uma casa da minha mãe, sabe? Coisa que meu pai não me deu. Então, dentro dos conceitos sociais, do macho que deveria prover isso e aquilo, com minha mãe não tem essa. Ela se dedica ao trabalho e a coisa acontece. É trabalho mesmo! E tem esse lado provedora, macho, sendo fêmea.

\section{Cirurgias e modificações corporais.}

Essa questão se referia às expectativas sobre a proximidade da cirurgia: os cuidados, o tempo de repouso, os investimentos. Feiticeira do Mar aproveita para comparar a convalescência com outros procedimentos cirúrgicos.

Eu quero viver uma experiência minha. Acho que a experiência é única de cada ser. Eu imagino que quando eu fizer a cirurgia, nos primeiros momentos, será um pouco chocante. Tem uma parte dramática, já ouvi dizer. Cada pessoa reage de uma forma. Toda cirurgia é assim. Quando fiz os seios, meu deus! Eu tive que amarrar uma corda na beira da cama para puxar, poder me levantar e sentar. Porque essa parte aqui ficou imensa.[mostra com as mãos como os seios ficaram] $E$ dobrou de tamanho. Uma coisa bem inchada, bem demorada. Mas aos pouquinhos foi indo e depois de um ano estava bom. Ficou maravilhoso! Já o nariz, para mim, eu fiz num dia e no outro dia já estava numa festa. - "Tu é louca, vai pra festa?" -Eu vou, estou ótima! (risos)Mas sobre a cirurgia, vou querer uns calmantes antes, porque acho que vou ficar uma pilha. Reaprender a viver com outro órgão é a mesma coisa que fazer 
um transplante ${ }^{176}$, né? As pessoas fazem transplantes e têm de saber conviver com aquele fígado e cuidar dele. Então, eu vejo assim, para mim, eu vou passar pela cirurgia de uma maneira muito boa. Não vou me pôr a sofrer. Acho que os primeiros momentos da internação, o antes, o pré-operatório, talvez vá me causar uma ansiedade. Eu me conheço. Mas não tenho assim grandes medos.

"Mudança de sexo."177

Porque na essência, pra mim, não muda nada! Não fico pensando se a vizinha está pensando se eu sou isso, sou aquilo. Então essa coisa de transexualidade, mudança de sexo, nada! É uma adaptação do teu interior. Da naturalidade, da descoberta, da permissão de ser quem você é. Na descoberta de quem você é, também. Porque não é uma coisa só assim: "“Ah ela é uma travesti. Ela é uma transexual. Ela é isso ou aquilo!" Cada um é o que é. Não vejo como mudar o meu sexo. Nunca vou mudar meu sexo. Eu sou mulher e pronto! Não tem como mudar meu sexo. Vou mudar para ser homem? Não tem como ser homem! Eu posso ser macho, guerreira, trabalhadora, milhões de coisas. Mas ser homem? Não tem como!

\section{“Anatomicamente transformada!”}

A coisa mais incrível que ouvi dos relatos das meninas [as participantes do Hospital de Clínicas de Porto Alegre]foi de uma que se operou e saiu da cirurgia, botou a mão e disse: - "Mas, o doutor não me operou, ele não me tirou nada!" E ela estava operada. Ela sentiu e disse: - "Doutor, ainda bem! O senhor me operou mesmo? Porque está tudo aqui! Eu sinto tudo! Não foi me tirado nada! O meu medo é que eu não sentisse mais nada ali naquela região". Ela ficou feliz que não foi castrada, ela foi transformada, entendeu? Anatomicamente transformada! E isso foi uma coisa muito boa, para mim. E eu sinto e desejo que seja assim para mim também. Eu mereço esse presente de Deus. Eu mereço esse presente de Deus, né? Uma boa recuperação, Uma boa alegria! Uma nova fase nessa gaveta. Porque eu me vejo

\footnotetext{
176 Se para Bruxa Malvada do Oeste, a cirurgia irá consertou uma "anomalia", um "lábio leporino", para Úrsula - a Feiticeira do Mar será como transplantar um órgão, "anatomicamente transformada". Veremos nos próximos capítulos que para Maga Patalógica a cirurgia foi como "extrair um dente" e para Malévola será "adequar" a genitália à sujeita.

177 Como visto no capítulo inicial, o termo "mudança de sexo" é expressão usada pelo senso comum, pela percepção equivocada de que se "troca" um sexo por outro. Utilizou-se aqui, pois nas memórias da interlocutora, teve de explicar diversas vezes sobre esse equívoco para ser compreendida pelas pessoas.
} 
como um grande armário: tem várias gavetas aqui. E nessa gaveta eu mereço esse presente de Deus, Porque muitas vezes já chorei por ter um certo desgosto de olhar uma região do meu corpo que eu não gostaria que fosse dessa maneira. Não gostaria. Mas se eu recebi essa bagagem ainda bem que Deus está dando também a clareza e o presente de ser transformada nessa área do meu corpo. Eu não sou só uma vagina, também. Nem um pênis. Eu sou um ser humano! Porque a última coisa que eu penso quando eu estou trabalhando, quando estou na rua fazendo as minhas coisas. Quando estou namorando, ou no mercado, fazendo as coisas quotidianas, que eu tenho ou não tenho uma vagina. É a última coisa que eu penso. Sou uma mulher comum como qualquer outra. Sou mulher igual às outras que estão por aí, valorizando e detestando a vida, vivendo e sofrendo. Sou igual a todo mundo!

\section{Os documentos civis e a menina/mulher sem bula.}

A Feiticeira do Mar utiliza ainda os documentos com o nome de batismo. Embora provoque constrangimentos, prefere, por questões que consideramos de ordem prática (e quiçá filosóficas), modificá-los após a cirurgia. Nas lembranças, trechos da infância surgem para ilustrar o que para ela significa "não ter vindo com bula".

Eu não sou uma carteira de identidade, tão pouco um documento de nascimento (risos).Sou um ser muito além disso. Apesar de ser necessário para viver socialmente dentro de um padrão, sem se incomodar e querer que te olhem de outra maneira. Porque não existe outra forma das pessoas olharem um documento e olhar para a tua cara e ver se você parece ou não parece, é ou não é. Viver sob esse julgamento é doloroso! Pelo menos para mim, como ser humano, é chato! [Ter de apresentar os documentos civis]. É chato porque você se lembra de uma coisa chata. Que eu não gosto de conviver, porque não sou eu. Porque eu não sou um documento. Deram-me um nome, sim. Coitados! Não sabiam, também. Não vim com manual de instrução: -"Olha ela é diferente. Ela nasceu com aquele corpinho ali, mas ela é igual a uma outra mulher. Mas ela tem aquele corpo ali. Isso vai ser a batalha da vida dela!" Não nasci com essa bula, não vim com uma bula de remédio, entende? Não vim com uma bula: "Ah, fulana é diferente! Fulana está de saia no recreio. Chama a mãe! Chama a mãe porque a criança está..."- Na minha época era 
doença:- "A criança está doente!" "só anda com as meninas. Não quer saber dos meninos." Vai à praia bota as mãos nas tetas para não aparecer. Não tira a camisa. Usa roupas largas. E aí de mim se eu falasse que sentia alguma coisa que eu nem sabia, porque a sociedade oprimiu tanto e a convivência nos meios a que fui submetida...

Acho que muitas ou quase todas não vêm com essa bula, entende? Você vai descobrindo a tal bula. Você vai escrevendo a sua bula com o tempo. Diante de todas as experiências que se tem na vida. Experiências sexuais, inclusive. É assim para as meninas que eu vejo. Então, um belo dia a pessoa se descobre. Que bom! E se redescobre e se reinventa. Ainda bem que não sou um pote de maionese! (risos).Lá dentro tem maionese e está escrito "maionese". Vai ser sempre aquela maionese. Ainda bem que não sou assim. Eu vivo a vida conforme eu vou vivendo. Mas não vejo outra maneira de ser diferente de como eu sou. Posso ser melhor, posso até me piorar. Mas ser diferente da minha essência, não tem como.

Continuo com o nome antigo o qual me deram. Eu vivo com esse nome, mas raramente tenho que apresentar. Para pouco me serve. Seria muito dolorido se eu tivesse uma tatuagem com o nome escrito na testa. Isso para mim seria o fim do mundo. Vou deixar para fazer tudo num pacote só. Deixa o nome para depois[após a cirurgia].

\section{Para você o que é ser uma mulher?}

Vamos definir... Se tiver como definir. Em que campo? Na parte biológica? Gerar? Parir? Menstruar? O que é ser uma mulher dentro de um contexto psicológico e social? Porque existem mulheres e mulheres, homens e homens. $E$ as definições $e$ nuances. O que define uma mulher não é parir ou ter menstruação. O que se define para mim é a minha autodescoberta como mulher. Nisso a vida foi muito generosa. $E$ dentro de uma concepção de semente, de essência, não me vejo diferente. Por mais que as pessoas digam: - "É uma mulher diferente!" Não, eu não sou uma mulher diferente! Meu corpo foi diferente. Minha grande libertação foi perceber que eu não sou diferente: eu sou igual a todas as mulheres. Por mais que as pessoas, o mundo, uma parte do corpo me disser que eu sou diferente, eu não me sinto diferente. Eu 
me sinto igual. Isso me tranquiliza. Isso mantem viva minha parte psicológica. Isso me faz lutar para viver e simplesmente me deixar viver. O fato de ser igual, humana, pessoa, mulher, fêmea. Posso não ser totalmente feminina, mas sou fêmea. No jardim de Deus, todas as flores, mesmo as gérberas muito gérberas e as rosas muito rosas. Cada rosa tem o seu perfume, tem seu espinho. Então, no jardim de Deus, eu sou essa mulher que eu sou. Como ser outra mulher? Não tenho como ser outra mulher! Eu sou a mulher que eu sou. Para mim basta! Ponto! Fim!

\section{“O corpo não me limitou!"}

Em comum com a trajetória da Bruxa Malvada do Oeste, Úrsula percebese mulher a despeito de haver nascido com um pênis entre as pernas. Se no caso da interlocutora anterior a cirurgia permite, por assim dizer "maior segurança" na afirmação, nesta sujeita, o autorreconhecimento ou autoidentificação não se limita a algum evento futuro. Ao contrário, preexiste à cirurgia e na autonomia de si, ultrapassa quaisquer supostas verdades biológicas.

Vejo-me, me sinto, sou! O corpo me disse que não? Um corpo me limitou? Até quando sou? Até quando não sou? Até quando me permito ser? Aonde me encaixo em mim mesma? O corpo não me limitou! A adequação não vai me mudar. Não! Eu vou me transgenitalizar, apenas! É prático! Mas até onde eu sou mulher? Até onde você é mulher? Até onde minha mãe é mulher quando tem de ser macho? Para ser a provedora, para ser a guerreira? Então, é muito complexo... Eu me dei conta disso também através da ajuda de outras pessoas para me libertar de certas coisas. Dessa ideia fechada de que o corpo me limitaria. E quando eu vi que não era só um corpo, alguém bateu no meu ombro e disse: - "Seja você! Por mais macho ou fêmea que seja. Seja!" E me permiti ser. Guardo essa certeza porque me identifiquei com essa resposta. Com esse encaixe do ser: de eu comigo mesma.

Você pode tentar ser milhões de coisas. Mas eu não posso abandonar minha essência se eu tenho uma reposta de que sou feminina e não preciso fazer força. Não faço força para ser essa pessoa que sou. Não sou o que os outros gostariam que eu fosse. Não me vejo de outra maneira que não sendo fêmea, feminina. Gestora? Vou gerir um ser? Sim! Quem sabe?! Vou gerir. Vou adotar. Vou criar. Vou fazer! Vou exercer meu lado maternal. Ah! Que bom seria se tivesse noutro corpo! Ter muitos filhos! Não teria problema nenhum com isso. Porque lamento não poder 
ter meus, paridos, meus [filhos]. Ver a minha cara estampada ali naquela criaturinha (suspiros). Seria maravilhoso! Não tive, tudo bem!

\section{A visão das colegas de trabalho.}

Fumando um cigarro na janela de seu quarto, Feiticeira do Mar relembra as conversas com as colegas de trabalho. As comparações com travestis e transexuais parecem não a incomodar tanto quanto ocorre com as outras interlocutoras.

As colegas de serviço falam mal das travestis, das transexuais. Falam assim: - "Mas eu conheço a Úrsula. A Úrsula é uma mulher! Não tem como a gente dizer que ela não é, né? Porque ela é uma mulher todinha, gente!" Aí, para tentar comparar elas dizem assim: - "As vezes tem umas travestis lá perto de casa para fazer programa. Ela não é igual aqueles travestis que eu vejo lá! Gente, você é feminina igual a nós e não igual a eles!" Então, existem essas nuances que elas identificam a mim como igual a elas. E sou, né? Então, não sou só eu quem fala. Elas pensam: - "Ela não é transexual, é uma mulher! Tu es já operada, né? Deve ser muito estranho... Porque tu es uma mulher todinha". "Teu jeito de ser, de entender as coisas, de acolher as pessoas. Não tem diferenças entre nós”. Porque existe aquele padrão, né? Que me difere daquelas pessoas lá. Então, elas falam isso para mim assim: - "Mas a Úrsula não é, né? A Úrsula é mulher igual a nos!" Não sou diferente. Eu sou igual. Só o corpo que foi diferente. Eu, essência, é igual a todas.

\section{Sobre a identidade "transexual" ("Essa coisa de transexual”).}

Em alguns momentos do trabalho discutiu-se acerca da existência da suposta identidade "transexual". Neste trecho, as respostas às indagações foram sanadas da forma como estão: em tópicos. Para Úrsula - a Feiticeira do Mar, o problema que a medicina, a psicologia, o direito se propõe a solucionar só será resolvido com a intervenção cirúrgica e as alterações jurídicas. A interlocutora deseja a adequação genital e mudança do prenome não porque seria "transexual", mas porque é mulher. A identidade "transexual"- se houver- não se refere a ela. 
[sobre transexuais] E será que isso não existe para algumas pessoas? Eu não tenho como viver o que os outros vivem. Eu tenho como falar de mim. Eu tenho como ser eu. Eu sei ser eu. Eu não me enquadro num conceito de que seria do grupo macho porque não tem como. Essa coisa de transexual (tom de deboche). - "Porque você é isso!" [transexual]- Tudo bem, quer chamar disso aí? Você entende assim? Tudo bem! Não, mas tenta viver dentro de mim. A minha verdade não é a verdade absoluta para todas as pessoas! A minha verdade me basta e pronto! Fim! Ponto! Eu sei de mim. O juiz lá vai botar na minha carteira de identidade - "Ah, ela é transexual"?! Não aceito isso! Não aceito isso! Não fiz o que a sociedade pediu? A medicina vai lá transgenitalizar e pronto! Só troca o nome e grande coisa! Qual o problema?

\section{Ofensa e reconhecimento.}

A percepção da interlocutora sobre insulto ou ofensa pelo não reconhecimento da sua identidade ${ }^{178}$ de mulher parece situar-se num patamar de compreensão e tolerância. Há uma multiplicidade de sentimentos vividos por Feiticeira do Mar a depender do espaço social onde o termo "transexual" é utilizado para identificá-la: se for em ambientes hospitalares não vê exatamente como ofensa, e sim, um mal necessário à consecução dos seus objetivos; na rua e espaços púbicos, admite que não lhe agrada, porém sabe que com estranhos não poderá fazer muito para que a vejam como mulher, a não ser ficando "invisível" ${ }^{179}$, como se verá adiante. Em todos os casos, a interlocutora deseja ser reconhecida enfaticamente como mulher, inclusive não de um tipo extraordinariamente singular, mas uma "igual a qualquer outra".

\footnotetext{
${ }^{178}$ Como discutido no primeiro capítulo com as obras do antropólogo Luís Roberto Cardoso de Oliveira.

${ }^{179}$ Como se verá mais a frente, a "invisibilidade" também é uma estratégia usada por Malévola. Interpretamos essa invisibilidade da seguinte forma: não ser muito notada por estranhos em situações quotidianas, pois ao ser esquadrinhada alguém poderá não mais percebê-la como mulher e agir com preconceito ou violência. As travestis, por exemplo, são muito visíveis no dia a dia, seja essa ou não a intenção, por isso elas costumam sair às ruas apenas a noite, como visto em Kulick no capítulo primeiro. Talvez ficar "invisível" signifique igualmente não ser vista como travesti. Já a invisibilidade na aproximação teórica com Honneth guarda a ideia de não ser vista ou identificada como de fato é: os traços que compõem a identidade da sujeita são não percebidos ou propositalmente invisibilizados por terceiros.
} 


\section{Sente-se ofendida quando confundida com "transexual"?}

Não me sinto ofendida porque as pessoas que perguntarem isso a mim não terão a visão de quem eu sou. Elas vão falar isso de uma maneira pejorativa ou modo de elogiar? Depende! Eu não gosto! Mas também não posso escrever um cartaz e pendurar em mim: - "Não me chame de tal coisa porque vou me sentir ofendida porque não sou essa coisa!" - Eu não tenho como. Eu me preparo no sentido de muitas vezes, as pessoas não saberem quem eu sou, independentemente de sexualidade, de sexo, ou de parte biológica: de vagina, de pênis, de qualquer outra coisa. Não me sinto ofendida em ser eu. Eu acabei de dizer que sou mulher. Logo, não me preocupo tanto se me veem de outra forma.

Porém eu faço leitura labial. Às vezes de longe uma pessoa olha para outra e diz: "Mas ela não é mulher." Eu vejo a leitura labial e eu digo, penso para mim: "Para você (ênfase em "você") eu não sou!". E não tenho como mudar os traços masculinos que o meu corpo me deu. Eu sou uma mulher para mim! Na minha luz! Inclusive algumas pessoas dizem: - "Nossa! Mas você é muito mais bonita do que muita mulher!" Eu digo: - "Que bom!" - Se ela acha que deve me colocar nesse padrão de beleza. Daí insistem: - "Ah! Ela é mais bonita que uma mulher."- Sim, mas eu sou uma mulher! E aí? Me diz? Como é que fica? (risos). Eu sou uma mulher! $A$ beleza é um padrão que vem de questões culturais. É uma luta muito dolorosa para todas as mulheres. Essa imposição do padrão sabe? O padrão é para todos. Até homens, né? Agora tem de ter um padrão estético, assim ou assado e tal e tal. Então, é uma questão da sociedade inteira. Do mundo inteiro, do ser humano: a busca pela estética. Não fico me torturando em cima de um corpo que eu ganhei da vida. Ser tão dura comigo mesma. Não serei boa para mim se eu me impuser tanto.

\section{E se alguém suspeita que não nasceu com vagina?}

Como quem diz assim: - "Ah! Ela pensa que é, mas ela não é mulher". Os traços da pessoa que nasce com atributos masculinos... Porque o corpo veio com aquele pacote masculino ali então...Não há muito que fazer. Incomoda-me?(reflete um pouco mais antes de responder) Não! Porque meu marido não chega em casa dizendo: - "Ah. Você é um rapaz!"(risos).Me incomodaria se fosse alguém de muita estima, de muita amizade sempre ficar me lembrando, querendo me afirmar uma coisa que meu próprio espelho já me diz. Porque eu tenho espelho em casa. Não 
gosto de muitos traços. Porque batem exatamente no meu lado psicológico, na crença de que é uma essência feminina carregando um corpo que muitas vezes não tem os traços que eu gostaria de ter. Eu cortei a rejeição dos outros!

\section{Rejeição.}

Prefiro até desistir de um relacionamento se me causar dor. Se não estarei à vontade amorosamente, entende? Se a pessoa me levar a me sentir ofendida por uma questão só física. Prefiro não ter essa dor. Tanto que eu não queria me casar antes de fazer a cirurgia, para já cortar muitas dores nas quais eu pudesse viver. Porque eu não queria ter de fazer ou dizer que o outro deveria aceitar uma coisa que nem eu mesma aceitava. Aceito hoje porque vou fazer a cirurgia. Aceito porque eu estou convivendo com isso. Estou dando um contorno. Eu não queria ter que conviver todo dia com alguém. Eu não conseguia imaginar... Eu desistia... Desistia completamente dessas situações em que pudesse haver relacionamento. Para não ter de expor e sofrer a rejeição. Mas aconteceu o relacionamento antes mesmo do que eu imaginava. A pessoa sentiu a mulher que eu sou. E sou mulher e fim. Para ele está ótimo!

Ser comparada a "transexual" ("Eu sou uma mulherzinha assim, simples, humilde").

Não tem como ser comparada com transexual porque não sou (risos). Não sou! Como é que vou ser comparada? (risos)Na parte biológica, tudo bem. Porque vai transgenitalizar. Mas não tem como. Por mais que minha cara diga, que meu corpo diga, que esteja escrito ali. Eu não sou. Pronto! (risos)Não sou pra mim, não vou ser para os outros. - "Ah, porque ela é meio doidinha..." - Já me disseram: - "Ela é meio doidinha porque ela não aceita...Ela não aceita a transexualidade dela!" Como assim? Como é que eu vou aceitar uma coisa que não sou? (gargalhadas) Eu sou mulher e pronto! (risos). Como eu gostaria, né? Nascer de novo, tão bom, né? Não precisava passar por nada disso. Ter meu cachorro, meu gato, meu filho, meu marido, meu lar, minha história, meus documentos, enfim. É o que faz, o que monta um ser. É um conjunto de coisas que montam um ser. Agora, você ter de lutar com uma coisa ali [o pênis] que tu não gosta... Bom, uma mulher com aquilo ali? Sim! Sou uma mulher mesmo, mas estou nesse corpinho aqui, vai entender?!?Vai entender sim! Por que eu tive de entender? Por que eu tenho de contornar as 
minhas situações? Por isso que eu não queria me casar. Não queria conviver com marido todo dia com a calcinha cheia. Pelo amor de Deus, né? Eu sou uma mulher! É uma contradição terrível [mulher com pênis].É uma coisa contraditória. Mas eu não tenho como mudar a história. Está bom, vou operar. Tudo bem! Eu vou ser mais mulher do que eu sou? (gargalhadas)Ainda assim, eu não quero ser mais do que outra mulher. Sou a mulher que sou. Não quero ser a supermulher!(risos) Eu sou uma mulherzinha assim, simples, humilde. A mulherzinha assim do jeitinho que eu sou. A mulherzinha simples, amando com o coração do jeito que eu amo. Porque eu não vou mudar. Transgenitalizar sim; transexual, não! Transgenital, sim! Transexual, não! E não vou jogar pedra no mundo porque insistiu em ver essas questões da maneira que vê. Não vou, né? Porque a mulher que eu sou nem é para isso. Nem está nesse nível ali. De querer bater de frente. - "Vou mudar o mundo à superwoman"? (irônica) Não! A mulherzinha assim do jeitinho que eu sou tá bom!

\section{A submissão à categoria "transexual" e aos "especialistas".}

Como visto acima, Úrsula - A Feiticeira do Mar está inscrita num dos programas do Ministério da Saúde (MS) que gerenciam o "Processo Transexualizador do SUS", o PROTIG. ${ }^{180}$ Seja porque aguarda ansiosamente pela cirurgia, seja por receio de retaliações, sua visão sobre os profissionais daquele programa: médicos, psicólogos, assistentes sociais, urologistas, entre outros não é tão criticamente enfática quanto à da Bruxa Malvada do Oeste. Já a obrigatoriedade de se submeter à categoria patológica Feiticeira do Mar afirma não se importar, desde que obtenha a cirurgia que "consertará" a sua "falha" física.

Eu não vejo essas pessoas de todo ruim. Eu vejo essas pessoas como num grande processo de crescimento, de transformação, porque se não existisse essa parte que a gente não gosta [o tratamento médico-psicológico do transtorno de identidade de gênero]as coisas também não aconteceriam. Eu sou muito condescendente nesse sentido. Isso não é mais importante pra mim. Porque eu não vou lá para eles colocarem um tapete lindo e vermelho para eu passar. Não. O tapete vermelho eles

\footnotetext{
${ }^{180}$ Programa de Transtorno de Identidade de Gênero (PROTIG) que funciona no Ambulatório de Psiquiatria do Hospital de Clínicas de Porto Alegre/RS (HCPA). Outras informações em:

http://www.hcpa.ufrgs.br/content/view/528/768/

Último acesso em: 12/05/15.
} 
vão me dar quando eu sair de lá operada. Porque eles fazem de um tudo para ajudar as pessoas que chegam lá. Eu tenho uma falha. Então, não posso reclamar que o sistema tem algumas falhas. Mais ainda bem que tem, entende? Claro tem falhas lá. Mas estou chegando com uma falha também, então tenho de ter no mínimo paciência.

\section{Ser obrigada a "ser transexual."}

Vão me obrigar a ter uma tatuagem no rosto escrito "transexual"? (risos)Não, né? Não precisa, né? Então a coisa mais maravilhosa é quando eu entro no ônibus, que eu estou com muitos pacotes e um senhor se levanta e diz: - "Sente-se, senhora!". Essa é a sociedade maravilhosa que alegra meu coração! Porque eu percebo que eu consegui. Que a medicina conseguiu. Que os hormônios conseguiram, cada vez mais me deixar parecida com quem realmente eu sou. Isso me faz feliz, me tranquiliza, me acolhe, me acalenta. Me dá forças para continuar vivendo! Porque viver à margem das coisas onde você é fustigada, moída, retraída, oprimida, não tem coisa pior. Esses presentes: "sente-se, senhora". Esse "senhora" bate lá no fundo da minha alma e digo: "Deus existe". Isso me aquece a alma, entendeste? Isso me adequa, me tranquiliza! Não importa se me obrigam. Ninguém me chama de transexual. [na vida quotidiana]Mas tem de dar um nome. E se eu tiver de carregar esse nome lá dentro[do hospital]como transexual para obter mais uma adequação na qual eu me sinta a mulher que eu sou, pra mim ótimo! Maravilhoso! Tanto que eu sou a primeira a dizer: não precisa mudar a identidade agora. Muda depois. Não tem grilo! Eu sou mulher mesmo. Se quiserem me chamar de outra coisa, podem me chamar!

\section{A longa espera.}

O tempo de espera provoca oscilações de sentimentos em Úrsula. Com a ajuda da fé religiosa consegue tranquilizar-se, aceitando a demora com mais facilidade. No passado, houve momentos de muita dor e angústia. Como visto no capítulo inicial, a categoria médica requer um protocolo de espera e as filas só crescem, aumentando assim os tempos de aguardo. Quando a indignação sobe-lhe à cabeça, pensa em pedir empréstimos para pagar a cirurgia em clínica particular. 
Em seguida, reflete que de fato, com os impostos de todas e todos, inclusive os dela, já teria quitado há tempos seu próprio procedimento cirúrgico. ${ }^{181}$

A espera pela cirurgia tem sido, digamos, esclarecedora e também decepcionante. Porque com 40 já não se tem mais 15. E querer dar na frente [fazer sexo vaginal], já faz muitos e muitos anos que eu quero. Mas se assim é a regra, quem sou eu para dizer. Então, eu vivo a espera cada vez com mais aceitação, resignação. Fazer desses momentos algo bom, porque eu não quero me prejudicar. Eu não quero viver em neurose. Mais neurose do que é o problema. Hoje, tento ser minha amiga. Aceitar isso [a espera] como uma dádiva de Deus. Um desafio ou algo que eu tenho que esperar. Porque diante do criador, não posso mudar. Eu tenho que agradecer. E não gerar mais dor em cima dessa que eu já tenho. Então, eu tenho que esperar...

Não! Eu não tenho que esperar. Estou esperando porque eu quero. Porque eu poderia mover um mundo inteiro e pagar uma cirurgia, né? Mas a cirurgia já está paga com meus impostos, né? Ou me pergunto, até onde tenho de passar pelos exames, para minha segurança... Mas se assim é a regra... Quem sabe um dia vá melhorar. Isso me incomoda?! Não quero que isso me incomode! Porque quando eu cheguei lá estava mais incomodada, porque eu queria logo. Eu queria logo! Eu queria com pressa (exasperada). Então, agora eu deixei lá. Os médicos cuidam disso. E eu cuido da minha vida.

Porque no hospital já tem quase quatro anos. Na verdade, eu fiquei esperando em Santa Catarina dois anos. Mais um ano daquele marca, não marca; faz isso, faz aquilo, vai na [terapia] individual. Mais dois anos e alguma coisa de [terapia] grupo que eu estou - quase três. Portanto, dentro do programa total já são seis anos. Fazer o que, né? Viver no sofrimento, não é muito bom, não. Esperar é ruim! Mas se assim é, eu sigo em frente.

\footnotetext{
${ }^{181}$ A Portaria GM/MS no 457/2008 registra o valor de $R \$ 1.113,57$ pelos procedimentos cirúrgicos de "redesignação sexual" que o Estado custeia em cada intervenção. Ver em: http://bvsms.saude.gov.br/bvs/saudelegis/sas/2008/prt0457_19_08_2008.html Já a Portaria 2.308/2013 atualiza esse valor para $\mathrm{R} \$ 1.288, \overline{8}$. Ver em: http://bvsms.saude.gov.br/bvs/saudelegis/gm/2013/prt2803 1911 2013.html Último acesso em: 12/05/15.

De todo modo, na Rede Pública de Saúde essa intervenção cirúrgica custa para o Estado menos que $\mathrm{R} \$ 1.300,00$. Já nas clínicas particulares pode chegar a $\mathrm{R} \$ 50.000,00$.
} 


\section{Relacionamentos afetivos.}

Eu adorava antes de ter homem à disposição na hora que quisesse(fala pausadamente, como uma criança peralta): ficar três meses sem gozar. Adoroooo! (risos)Chega sai faísca dos olhos (gargalhadas). Parece que sobe assim um fogo, uma energia que te transcende. É uma coisa incrível essa experiência. Eu nunca dei muita bola [para transar]. Claro que tem as questões hormonais... Ele [o hormônio feminino] me faz um bem maravilhoso. Meu corpo fica adequadinho ao que meu cérebro precisa $^{182}$. O hormônio é ótimo pra mim! Me deixa completa. Uma partezinha ali no corpo, na vida, que me adequa. Porque uma das coisas que mais me deixava furiosa é ter essa coisa aí, a ereção. Ficava arrasada! ${ }^{183}$

\section{0 atual marido.}

Úrsula - a Feiticeira do Mar não me narrou em detalhes onde e como conheceu o atual marido. Disse-me apenas que se esbarraram num ônibus e "nunca mais se desgrudaram". Estão juntos há cerca de quatro anos. Ele trabalha como pintor de interiores. Em casa, o esposo cozinha e a ajuda nas tarefas do lar. Muito amoroso em todos os momentos, nos lugares públicos ou em casa, faz carinhos na Feiticeira, sem se importar com eventuais olhares de reprovação.

Eu sempre digo para as minhas amigas: eu conheci os homens aos 37 anos! Eu achava que conhecia os homens, porém não é verdade. Ele [o esposo]me fez mulher! Esse carinho, essa preocupação dele comigo. Não que eu me descobri como mulher...Não! O aconchego, o acolhimento dele, é uma coisa mágica que não tem explicação. No primeiro toque dele eu me tranquilizei, eu relaxei diante daquilo all[as angústias com o sexo, com o pênis]. Ele me tratou da maneira que eu sempre gostaria que me tratassem. Então, foi revelador, no sentido sexual. Porque na parte emocional eu sempre me descubro cada vez mais.

\footnotetext{
182 Nas cenas de vida de Malévola explicitaremos mais sobre os efeitos dos hormônios no corpo das sujeitas.

$183 \mathrm{Na}$ narrativa da Bruxa Malvada do Oeste a ereção também aparece como algo muito desagradável. A relação com o pênis e a sexualidade para ambas não é ou foi positiva.
} 


\section{"Quando me namoro, eu consigo namorar o marido".}

Quando minha profissão não me ocupa muito. Quando minha cabeça está boa. Quando não estou estressada com as contas. Eu estou namorando. Porque eu sou assim: para namorar a geladeira tem de estar cheia, a casa tem de estar boa, bem organizada... Eu me namoro, né? Eu tento me namorar, porque quando me namoro, eu consigo namorar o marido. Tento me namorar, sabe? Me botar para cima, porque da porta para fora tenho que me blindar porque senão fico louca. Tenho de me blindar, esquecer. Me firmar no invisível. Para não querer absorver os olhares, senão estou vivendo a vida dos outros. Se eu pensar o que estão pensando de mim. Se estão me olhando, se não estão me olhando. Se estão me desejando, se não. As pessoas falam: - "Pô, mas tu levou uma cantada. Uma olhada assim..." Nem percebi. - "Um cara passou, ficou te olhando com um olhar assim..." - Eu nem vi. Eu nem vejo. Eu fico tão centrada me botando numa almofadinha azul, para não ter que ficar nesse sofrimento do que estão pensando. Quer dizer, as coisas boas também vêm, né? Então eu anulo tudo. Eu tento viver na minha redoma. Se eu me preocupar se estão pensando bem, se estão pensando mal, eu darei margem para não sentir o que eu gostaria de sentir: paz. Independentemente de tudo: paz! Essa é minha grande batalha: estar em paz comigo. Porque se eu me preocupar: Ah! Olhou bem! Será que ele olhou bem, mesmo? - "Ele falou que você é bonita!"- Nossa! Como me falam "bonita", "gostosa". Para algumas pessoas isso faz uma grande diferença, para mim não faz diferença nenhuma! Não faz o meu ego crescer: - "Ah, Eu fui desejada hoje. Isso foi importante pra mim!" Não sei. Acho que tenho uma blindagem contra isso.

\section{Passado.}

Úrsula não me narrou cenas específicas da infância, adolescência ou vida adulta. Disse não gostar de se lembrar. As emoções mais fortes daqueles períodos são como grandes nuvens escuras: amplas, infinitas, densas. Está tudo lá. Aqui. Parece nunca ter cessado. A dor é evidente: um lamento, um choro miúdo. Apesar de não haver o tempo passado (ela diz sempre tudo no tempo presente!), essa é a forma como a interlocutora parece lidar com as suas dores: deixando-as no passado. 
As imagens da infância e adolescência ficaram nas fotografias guardadas na casa da mãe. Respeitei os momentos de silêncio e não insisti.

Cada vez mais amadureço diante de um passado no qual eu não posso apagar. $E$ fazer desse meu passado algo muito mais bonito do que me fizeram acreditar que ele era. Então, eu não quero mais contribuir para os comentários dolorosos, porque para mim foi doloroso, é doloroso. É doloroso sim! (longo silêncio) Porque não pude viver na minha adolescência os beijos virgens que qualquer menina pode dar. Que seria meu sonho. Porque meu corpo me impediu disso. De exercer simplesmente a minha essência. Hoje vejo que me faz falta. Eu não vivi isso. Eu gostaria de ter vivido. Hoje vivo com meu marido coisas que me permito viver, nas quais não vivi com 15, com 18, com 20. Estou mais segura comigo nesse sentido, porque não quero mais fazer do meu passado algo feio e doloroso. Passou. Passou e eu não posso no momento ainda reafirmar que tudo foi dor. E sim, passou. Eu tenho outra imagem. Eu tenho outro primor para zelar. Para cuidar. Para viver. Para não me deixar ruir. Não me deixar contaminar por pesadelos de coisas que eu já vivi. Então, eu fico me reinventado na paz. Na tranquilidade. Na aceitação de mim mesma. (silêncio)Eu não tenho uma foto de quando fui criança. Está tudo na casa da minha mãe. Não quero ver. Tenho as imagens todas na minha memória, de todas as fotos que eu tenho, na casa da minha mãe. Mas eu não tenho uma foto sequer. Porque não quero ver. Gosto de ver hoje. Olhar no espelho e ver hoje: - (se vê no espelho)Ah, um botoxzinho aqui, uma coisinha aqui. Estou bem, estou bem! Esquece o passado! Fim! Eu já tenho a bagagem de carregar um corpo que é uma coisa meio complexa. Ainda ficar relembrando, revivendo. - "Ah por que eu fui daquele jeito?" Eu não pude viver de outro jeito. Eu revivi toda essa dor. Toda a infelicidade que eu tinha comigo. De olhar para mim no espelho e dizer: - "Essa não sou eu. Essa pessoa não sou eu!" Não me identificar com um traço. Apenas os meus olhos eu admirava no espelho. O restante para mim não precisava existir. Dizem que os olhos são o espelho da alma. (silêncio) Hoje consigo ver que eu consegui. Que o corpo não me limitou. Que eu tive ajuda. E gasta-se muito dinheiro para você pelo menos apagar, passar uma borracha. Vai fazendo aquele photoshop na vida. Para você pelo menos ter uma aparência na qual você se sinta bem, né? Isso é fundamental! 


\section{Lamento.}

A única coisa que eu lamento na vida é não ter força para lutar e lutar em vão. Isso pra mim é o fim. Pra mim isso é o fim! Não ter força para lutar e dizer: - "Teu caso não tem nenhuma solução". Isso é horrível. Isso me faz chorar. Isso me faz triste. Mas enquanto há contornos, retornos, retoques, vamos continuar. Vou continuar. Vou continuar sim! Vou continuar com as exigências da beleza. A beleza gera dinheiro, a beleza gera o mundo. O belo é lindo e Deus é belo. Acho que a coisa mais linda que Deus dá no coração de uma pessoa é admirar a beleza e querer a beleza. A beleza das coisas para mim é fundamental. Senão para, né? Para tudo.

\section{Futuro: envelhecer e morrer. (“Uma coisa gloriosa, como um pássaro!”).}

Meu objetivo para o futuro: envelhecer! Colher mais coisas boas. Plantar mais coisas boas. Não tenho grandes planos. Admiro as pessoas que conseguiram zelar por si mesmas e envelheceram bonitas. Porque quando eu era criança eu via nas revistas de moda as velhas bonitas, as pessoas bonitas. Isso é importante pra mim! Gosto muito disso: envelhecer, viver. Só não sente dor quem já morreu. A velhice traz dor, muitas vezes doença. Ou não. Eu tinha uma tia que dizia assim: - "Eu não vou morrer. Eu vou dormir". E realmente ela escolheu. Ela acordou morta. Ou não acordou. (risos). Jantou. Deu boa noite. Fez a caminha dela. Tomou banho. Passou um creminho no rosto. E dormiu. Sem sofrimento, sem incômodo, sem gritaria. Uma coisa gloriosa, como um pássaro! Deixou até o rádio ligado:- "Ouçam uma música que eu estou partindo. Beijos." Que glória, né? Se todo mundo pudesse ter isso. Morrer em pé, morrer sem uma grande doença. Sem se carcomer, sem se definhar. Isso é uma glória! Devia ser assim para todos. Que desejo idiota que eu tenho. Mas deveria ser assim para todos. Por isso eu a admiro! Disse que não ia morrer, ia simplesmente dormir. E partiu. Esse é o mágico da vida! Não se autodestruir, não se maltratar. Se transformou, se libertou e seguiu...

Seria um presente para mim, no dia que eu morrer, botar na minha lápide "Úrsula". Minha glória! Minha pós-glória! Porque pelo menos estará ali meu corpo, estará ali minha história. É o mínimo o que eu espero, como decência e acolhimento de ter vivido nesse mundo. Uma coisa muito simples que qualquer pessoa tem: seu nome 
na lápide. Um nomezinho escrito. Pronto! É vaidade minha? Quem sabe? Mas acho que é um direito, tão natural, quando se nasce, né? Não veio sem a bula? Não tem problema! As pessoas fazem o que podem né? Vá ser feliz mesmo assim! Vá recriar a vida e ser feliz.

As mulheres sem bula e o futuro.("Deus, manda gente preparada para recebêla!").

Úrsula - a Feiticeira do Mar acredita que assim como ela outras mulheres "nasceram sem bula". Como explanado acima, essas sujeitas ao nascer foram identificadas como "do sexo masculino" em razão de possuir um pênis entre as pernas. Nesse sentido, nascer sem bula significa dizer que a família e a sociedade não saberão como cuidar ou educar essa sujeita. Entretanto, com o crescimento se descobriram meninas, adolescentes ou mulheres que precisarão recriar a própria existência, reescrever o destino. Para essas, seu desejo é de que no futuro possa haver soluções práticas em idade mais tenra, assim como profissionais preparados para lidar com as sujeitas.

Não viemos com bula, né? A bula a gente vai escrevendo porque a gente veio sem. Então, eu desejo que haja uma definição mais detalhada. Uma descoberta mais antecipada para essas meninas. Um auxílio mais antecipado e preparado, para que não sofram tanto. Porque estou com mais de 40 e não fui operada ainda. Então seria mais ou menos assim o que eu gostaria que fosse. Não, mas primeiramente deveria mandar um telegrama para Deus, dizer assim: "Deus, dá um jeito aí, né? Não manda mais assim para cá!" (risos)Primeiramente isso, antes de tudo: -"Ah Deus não faz assim! Já manda pronta." Já manda pronta, sem dramas! Mas se não há possibilidade, se ela tem que ficar pronta depois. Se ela tem que se gerir, renascer, construir-se, tudo bem! Já não vamos mais pedir para Deus mandar diferente: “Manda gente preparada para receber ela, pelo menos, né?" -“Deus manda gente com cabeça, preparada para recebê-la!" Para receber ou para mudar a questão cultural. Mudar a cabeça das pessoas, do mundo: - "Ah, o caso dela é assim? Então vá lá na fila ali que você resolverá seu problema e terá uma vida normal!" $E$ isso seria bem cedo, com 13 [anos de idade], tá? Com 12! Evitam-se vários sofrimentos assim. Esse seria o futuro. Tem tantas novinhas que já sabem o que querem. Eles 
[no Hospital de Clínicas de Porto Alegre]queriam operar com 18 anos. Vetaram lá na lei. Disseram que não podia. Então, existe uma grande população ainda muito limitada de conhecimento. Mas é através desse conhecimento, desses estudos e dessas pessoas que se propõem a esclarecer o assunto como deve ser, que acredito que com o tempo as coisas vão melhorando.

\section{Magia.}

Embora religiosa, a Feiticeira do Mar tem vocação para a magia. Nas relações mágicas encontra alguma possibilidade de sentido para a vida. Antigamente costumava utilizar o baralho cigano ${ }^{184}$ para a leitura dos caminhos próprios e de pessoas queridas. Hoje com a fé messiânica não sente mais a necessidade, guardando as cartas para momentos muito específicos. Sobre uma amiga que precisou dos seus conselhos mágicos, eis o que Úrsula lhe disse:

Sabe quando você tem a certeza de que já sabia que algo iria acontecer e realmente acontece? Pois é! Eu sempre tive ranço de cemitério, de tristeza, né? Um dia uma amiga disse assim: -"Eu passei o natal sozinha. Você tem marido, queria ter um marido também."- "Tu Queres um marido? Então tu vais ter um marido!" Eu disse para ela. - "Vais ter um marido, do jeito que tu queres: uma pessoa legal, uma pessoa querida, um bom companheiro". Uma semana depois apareceu um homem na vida dela. Ela achou que eu tinha feito uma grande magia. E talvez tenha feito, mentalmente. Desejei a ela algo bom porque ela estava chorando que as outras tinham e ela não tinha. Eu digo: "Te dou um marido, mas tem de fazer suas orações, seus pedidos com fé!" Não fui eu quem deu (risos). Não me comprometa. Porque eu não quero esse título: a bruxa que dá homem para as mulheres (risos). Apareceu um homem maravilhoso. Ai ela já começou a criar outro problema:

\section{Mas será que isso tudo é pra mim? O homem me trata maravilhosamente bem! Nunca fui tratada desse jeito. Nossa, o homem me leva ao restaurante, compra isso e aquilo. Ele é o homem que eu sonhei para minha vida! Uma coisa mágica... A Úrsula é bruxa mesmo!}

\footnotetext{
${ }^{184}$ Baralho Cigano, também conhecido como Petit Lenormand. Para saber mais sobre esse método divinatório ver em:

http://falandolenormandes.blogspot.com.br/p/o-sistema-conhecido-no-brasil-como.html

Último acesso em: 12/05/15.
} 
Eu disse: - "Bom querida, tu estás botando dúvida onde não tem! Deus te deu e tu estás botando duvida!" Está em dúvida? Não vai ser teu! Deus te deu uma pessoa legal, está vivendo coisas boas e ainda duvida?" Um mês depois o homem morreu nos braços dela. Ela mudou completamente comigo: - "Ah, eu acho que a Úrsula não é uma boa pessoa!" - "Ela não tem uma energia muito boa". -"Pediu tantas coisas boas, aconteceram coisas boas pra mim." - "Mas agora acabou, o homem morreu, olha que catástrofe!" Eu tive que ir ao cemitério que te mostreino trajeto de ônibus do aeroporto à sua casa ela me mostrou um pequeno e gracioso cemitério na ilha], $o$ único cemitério que eu achei bonito, harmonioso, com paz. Sem ranço, né? Olha a coincidência! Essas coincidências que eu te digo, são apavorantes, porque não é que eu queria, ter ido lá dentro daquele cemitério, enterrar junto com essa mulher, a família, enfim, o homem no qual eu pedi para Deus dar a ela. Mas aconteceu. $O$ máximo que eu pude dizer é que acima de tudo, existe Deus. Depois disso ela começou a fazer intriga comigo. Deixou o lugar que trabalhava com a gente e não tive mais notícias.

\section{Artista e costureira.}

Como visto acima, Úrsula - a Feiticeira do Mar é artista também. Atualmente, tem aulas semanais de canto e ensaia algumas canções. No mesmo sentido, planeja emagrecer um pouco e fazer alguns tratamentos de beleza, para num futuro próximo voltar atuar nos palcos.

Vou fazer a Carmem cover! Já ganhei vários concursos vestida de Carmem Miranda porque dizem que eu tenho uma semelhança muito grande com ela. Comecei a fazer aula de canto. Porque eu vou cantar, dançar e interpretar. Nossa, quando eu cantei para a professora, ela disse assim: - "Meu Deus! Tu tens tudo para cantar as musicas da Carmem!" Já são três músicas ensaiadas. E agora vou começar a pagar aulas de canto aqui no final da rua com uma outra professora para seguir com esse meu projeto. Emagrecer, perder barriga. Eu vou fazer! Só que eu não quero aquela coisa: - "Ah, é uma 'transexual' que canta Carmem. Uma 'trans' que imita!". (fala num tom de deboche). Nada disso! Sou uma artista que interpreta a Carmem! Eu ouço anjos. Meu anjo da guarda, meu próprio ser, Deus. Lá no aeroporto, Eu me vi como eu quero ficar. Realizando os dons artísticos que eu gosto :cantar, dançar, 
representar. É a minha vida! Meu sonho, antes de ser costureira, meu sonho era cantar, dançar e representar, alguma artista, alguma coisa... E toda vez que eu peço: Deus, eu devo seguir esse projeto? Me mostra! No mesmo dia aparece a Carmem, aparece uma foto, aparece alguém falando ou uma senhora chamada Carmem. Sempre vem um sinal. Um sinal divino que eu não devo desistir. Eu já queria estar operada. Já no corpinho 40, não 44 como eu estou. Mais magra, mais longilínea e cantando, dançando, representando. Mas se não foi vai ser ainda melhor! Estou me preparando. E dizem que Carmem é um perfil artístico de travesti e eu vou provar que não é. Porque eu não vou dublar. Eu vou cantar! Eu vou subir lá e vou cantar! Não vou fazer um fantoche de dublagem. Eu vou estar vestida. Figurino, não fantasia! Esse é meu sonho. Um dos que eu vou realizar. Vou começar como uma brincadeira. Depois vou me profissionalizar. Eu tenho a costura que não me dá dinheiro, mas me dá uma pequena estabilidade. É produção, né? Não é fazer uma bainha numa manhã e tal. São 30/40 bainhas por dia. É um desafio! Além do desejo é um desafio de enfrentar, de ter o equilíbrio para enfrentar, com a tranquilidade, a plateia. Na verdade estarei enfrentando a mim mesma.

\section{Violências.}

A Feiticeira do Mar tem muitas histórias de violência e violação de direitos. Dentre elas, uma em especial ainda a apavora, pois foi duramente injustiçada. Há alguns anos, estava num shopping Center pagando contas e escolhendo mercadorias quando precisou utilizar o banheiro feminino, conforme sua identidade. Foi arrancada violentamente do estabelecimento pelos seguranças do shopping. Nervosa, suplicou para utilizar qualquer banheiro. Diante da negativa e absolutamente assustada fez as necessidades no meio do centro comercial, na frente de todos. Humilhada, com medo, sentindo-se menos que um ser humano foi para casa de ônibus. $O$ caso se tornou um processo judicial por discriminação. O juiz acatou os pedidos e condenou shopping. Mas o Tribunal cassou a sentença e hoje o processo está em altas instâncias ${ }^{185}$ à espera de uma decisão definitiva.

\footnotetext{
${ }^{185}$ Para proteção da intimidade da interlocutora se omitirão diversas informações que digam respeito ao processo judicial.
} 
Como visto em Peirano no segundo capítulo, os rituais de violência coletivas (riots), dão corpo aos conflitos etnoreligiosos e nacionalistas na realidade asiática. A situação de exposição pública no shopping sofrida por Úrsula pode ser um exemplo de ato ou ritual de humilhação pública que embora não envolva um evento ritualístico como descrito no trabalho de Peirano, tem impacto semelhante, caracterizando uma clara situação de agressão ou de abuso moral.

Além do evento no centro comercial, na audiência para tratar de eventual reparação de danos, a advogada do shopping de forma discriminatória tentava ainda agredir a interlocutora:

A advogada da outra parte insistia em me chamar de "ele". O juiz ficava do meu lado. Dizendo: - "Olha, você não pode chamá-la de "ele"! Você está vendo um homem na sua frente?"- Ele disse ainda:

Você está desrespeitando a parte! Porque ela é uma mulher. É vista como mulher e tem de ser respeitada como tal. Você está me dizendo que ela não é feminina o suficiente para estar dentro do banheiro feminino? É assim que a senhora pensa? Onde devo colocar esse ser que esta na minha frente? Essa senhora que trabalha? Essa senhora que vive na sociedade, que faz as coisas, que é gente? Você quer que eu a coloque onde? Dentro de qual banheiro? Do masculino? Para ela ser maltratada lá dentro? $O$ fato de vocês vetarem ela de ir ao banheiro feminino é absurdo! O banheiro é feminino e feminina ela é. É lá dentro que ela tem que estar. Porque ela não é masculina. A gente não está aqui para julgar a beleza, se é mais masculina, se é menos masculina, se tem traços, se não tem traços. Ela é mulher e pronto!

O juiz disse isso tudo para a advogada do shopping e terminou as instruções. Meus advogados disseram que a causa já estava ganha. Porque a outra parte apresentou uma testemunha a meu favor (a segurança do shopping que a retirou do banheiro).Ela disse assim:

Fui eu realmente. Não tenho nada contra ela. Mas fui obrigada porque os superiores me mandaram tirá-la de dentro do banheiro. $E$ agora tem um banheiro lá que é familiar. Onde a gente leva os velhos, os doentes, os negros, os mendigos e as transexuais...

O Juiz disse: "“Encerrou-se todas as instruções. não quero saber de mais nada. É muito preconceito! Vou tomar as minhas providencias!" O juiz falou: - "já tomei o fato por pessoal." "Porque isso não pode existir numa sociedade!" Nunca mais voltei 
naquele shopping. Mas soube que ainda tem o banheiro familiar. Tem o banheiro masculino, tem o feminino e o familiar, que se levam crianças para trocar fraudas, os velhos, os mendigos, os deficientes físicos. É um terceiro banheiro! Sendo que esse banheiro familiar deveria ser dentro dos banheiros femininos e masculinos, como um espaço maior para o atendimento das pessoas com necessidades diferentes. $E$ eles disseram isso: Que depois desse fato que aconteceu comigo eles criaram um banheiro familiar. E que os funcionários, os seguranças não poderiam desacatar as ordens superiores.

\section{"Eu me mijei e me caguei dentro do shopping."}

As cenas de violência e discriminação sofridas por Úrsula não apenas confirmam a ausência do reconhecimento e a ofensa da dignidade, como visto no capítulo primeiro, mas também afrontam toda a sociedade com a virulência na recusa do tratamento humano para com a sujeita.

Quando eu entrei para ir ao banheiro, que eu lavei as mãos para entrar no reservado, eles encheram o banheiro de segurança. Parecia que tinha uma criminosa no banheiro. Uma criminosa, uma serial killer. E me tiraram aos berros e puxões. Eu fui falar com os superiores e me disseram assim: - "Mas tu pensas que és o que? Tu és um putão, tu és um viado. Tu não podes frequentar o banheiro feminino!" Assim, desse jeito. Nesse tom. Não consegui fazer xixi, fui tirada para fora. Fui falar com os superiores. Já não aguentava mais de vontade de fazer xixi. Necessidade, né? Aí me chamaram na salinha. A tal salinha que eles botam a gente, as pessoas, para dar uma moral. Eles disseram:- "Voa daqui! Tu não és bem recebida aqui! Você não pisa mais nesse shopping. Porque tu és a vergonha. Tu não és uma mulher. Um horror! Como eu estava muito apertada depois que eu sai lá dos mandantes. Eu ainda insisti porque eu precisava fazer minhas necessidades. E daí, eles chavearam todos os banheiros do térreo. E quando eu fui ao segundo piso para procurar um banheiro, a segurança já estava toda avisada que banheiro nenhum tinha pra mim. Nenhum banheiro. Digamos que fosse masculino, mas com um guarda na porta para que ninguém entrasse e eu pudesse utilizar. Não, nada disso me foi oferecido. Eu me mijei e me caguei dentro do shopping. Não segurei. Eu já estava nervosa também. Não consegui segurar. Isso porque eu fui pagar uma conta no shopping de uns produtos que eu tinha comprado e tal. Eu cheguei na minha 
casa completamente fedorenta, apavorada, horrorizada e triste com toda essa situação que eu não precisava nem ter passado por isso. Não precisava ter passado por isso. Me arrepio toda. Fico muito aborrecida com isso. E fiquei apavorada com isso tudo. Fui pegar um ônibus, né? Daí, passou uma amiga que queria me ajudar, que me viu chorando na calçada. Serviu até de testemunha para mim no juízo. Ela queria me levar para casa. Mas eu ia sujar o carro da mulher. Não tem como sujar o carro da mulher, né? Toda mijada, toda defecada. Não tem como! Fui no ônibus, eu fui em pé. Aquele cheiro horrível. É desconfortante! É o quadro da dor. É o quadro da dor! Humilhante ao máximo!

\section{Sentimento de discriminação.}

E isso não foi discriminação? Faltou ainda o quê? Que tipo de prova que faltou se eu levei quatro, cinco testemunhas? $E$ todas disseram que fui discriminada. E depois o choque eu fiquei, a depressão, a tristeza. Eles me ameaçaram também. Mandaram um segurança ir atrás de mim, para ver se eu ia pegar um ônibus, para ver onde eu morava. Olha a perseguição! O homem desceu na mesma parada que eu, da minha casa. Nunca passei por isso! Eu vou a todos os banheiros, em todo lugar. Mas os órgãos públicos, os lugares públicos, às vezes me tratam de maneira discriminatória. É mais perigoso eu ir numa delegacia, do que ir numa lojinha, na padaria, entende? Eu entro com meu marido, com a minha mãe, com a minha família. Ninguém nunca chegou para mim dizendo: - "Você não pode fazer isso, você não é mulher!" Nunca. Só lá nesse lugar que eu fui. Se não foi discriminação eu não sei mais o que eu faço. Que cidadã eu me torno? Se isso não é discriminação o que é? Eu gostaria que um anjo no Judiciário dissesse: - "Essa senhora foi realmente discriminada!". Para que houvesse pelo menos um pingo de justiça. E que providências se tomem para que outras pessoas não passem por isso. Porque é doloroso, é horrível! Um shopping que recebe pessoas de tudo que é tipo, de gênero, de histórias. Às vezes vou a um shopping e evito até de ir ao banheiro, por medo de passar por isso de novo. Porque eu fiquei até traumatizada. Se eu estivesse acompanhada do marido, eu acho que seria diferente. Entende como é? As pessoas são muito hipócritas. Eu estar acompanhada com um homem, daí vamos respeitar. Porque eles disseram lá dentro: - "Tu estás circulando nos corredores, tu estás querendo clientes dentro do shopping". Vê se pode uma coisa dessas? Eu fui lá olhar tecidos para comprar, para uma cliente, fui pagar contas, essas coisas, do meu trabalho, da minha profissão. 
Que eu estaria caçando ou usando dos corredores como chamariz... Coisas horrorosas que eu tive de ouvir. Tanta coisa horrorosa! Gente completamente despreparada para lidar com ser humano. E muito menos com animal. Elas têm que se instruírem para poder lidar com pessoas ou serem afastadas. Não vão lidar com gente! Cria-se um terceiro banheiro para resolver um problema deles! Por que não sou bem-vinda ali? Na hora de consumir eu sou bem vinda?! Na época, fiquei com medo, com vergonha, de expor na mídia e não expus. Vieram pessoas querendo publicar isso, mas eu me senti uma formiguinha tão pequena perto de uma maquina poderosa que é um shopping ${ }^{186}$. E fiquei envergonhada, também. Porque eles criam uma coisa tão vergonhosa como se a gente fosse a vergonha do mundo. Eu fui vítima do que fizeram comigo. Isso foi maldade. No mínimo foi maldade. Será que eu não sou feminina o bastante para que me aceitem lá dentro do banheiro? Eles queriam me jogar na calçada, mas eu queria saber o motivo. Porque eu não fiz escândalo, não gritei. Não é meu tipo. Então, eu tenho que fazer o que? Eu tenho de levar um saquinho plástico que nem cachorro? Onde é que tem um lugar pra mim?

\section{Orgasmo.}

Nos grupos atrelados aos hospitais que fazem as cirurgias é muito comum que as participantes tenham dois discursos em relação ao sexo e ao gozo antes da adequação genital: nos corredores e salas de espera, falam abertamente sobre o tema, destacando inclusive suas predileções sexuais; nas salas de psicoterapia limitam o assunto às perguntas diretas ou acrescentam poucos comentários para evitar que não sejam indicadas aos procedimentos cirúrgicos em razão da atividade sexual prazerosa. No passado, um dos critérios compartilhado pelas sujeitas baseado nas expectativas dos médicos ${ }^{187}$ - era a condição de "quase assexuadas". $\mathrm{Na}$ atualidade, segundo a sujeita, ao menos no Hospital de Clínicas de Porto Alegre/RS, as práticas sexuais antes da cirurgia são até estimuladas.

\footnotetext{
${ }^{186}$ Se nas cenas de Bruxa Malvada do Oeste a mídia contribuiu para a discriminação quando expôs a sujeita nos jornais e, depois, nas dificuldades de entrar no mercado de trabalho, a situação de violência vivida por Úrsula - A Feiticeira do Mar a mídia se propunha a ajudar no combate à discriminação. Entretanto, o medo da exposição e das repercussões, com possíveis retaliações, fez com que a sujeita não procurasse os jornais.

${ }^{187}$ Basta lembrar, no capítulo primeiro, a pretensão médico-psicológica em encontrar "o transexual verdadeiro".
} 
O médico falou que toda mulher tem de descobrir o seu próprio orgasmo antes ou depois da cirurgia. As meninas estavam no grupo falando que não se tocavam, por que tinham bloqueio. Talvez tenha até um bloqueio psicológico por medo de serem consideradas isso, ou aquilo. Mas a consideração interior é a que vale para a pessoa. Ela transformará uma pelanca em outra coisa, né? Ai fica vivendo o drama de não poder ter um pouco de prazer na vida, depois ela como mulher, não vai ter que sentir prazer ali igual? Então, qual é o tempo do prazer? Eu vivia com essa neurose. Um dia eu falei com o doutor (o cirurgião-urologista chefe do PROTIG no HCPA) e ele me respondeu: - "Tu és uma mulher! Tu tens que ter tesão na frente. Vai ter tesão aonde? Na testa? Não é na testa o problema." Depois aquilo vai ser transformado em outra coisa. Só vai mudar a anatomia do órgão. O prazer vai ter que procurar igual ali. É também falta de informação, porque não tem nada a ver uma coisa com a outra. Agora se tem bloqueio...Tem mulher [nascida com vagina]que tem bloqueio também. Nunca se tocou. Não sabe o que é. Não sabe nem o livro que tem no meio das pernas. Tem um livro, uma biblioteca no meio das pernas, e não sabe. Então, elas se renegam antes de fazer uma cirurgia e depois elas têm que fazer o que? Vai continuar se renegando, porque botou um bloqueio ali. Uma coisa já vai ser transformada em outra. Claro que eu não gostaria. Mas é a única ferramenta que eu tenho agora. Vou fazer o que? Vou me matar? Não! Já estou no caminho para arrumar. Não sou ativa, mas é ali que tem que procurar prazer. A tua autodescoberta do novo órgão. Parte do princípio que você gosta de se dar um pouco de prazer e de se descobrir, né? Ser ativa não é o meu perfil. Mas tem muita menina ativa. Então, a questão toda é muito particular. $O$ doutor me disse e não disse só pra mim, não. Disse que tem que se estimular, porque depois tem de encontrar um caminho. E o orgasmo é humano! É independentemente de homem, de mulher. 
"E eu disse: se eu não puder ficar na religião, se os Orixás não me aceitarem, eu saio!"

[...] Dentro da religião do Candomblé, existem o que a gente chama de duas casas: a Casa masculina e a Casa feminina. Quando vai se fazer ritual para as pessoas que já morreram, somente os homens podem fazer. E quando vai se fazer ritual para celebrar a vida, somente as mulheres podem participar. E aí me perguntam: "qual Casa você ocupa, Maga?" Eu não sou homem! Jamais poderia entrar na Casa masculina. Mas na Casa feminina eu poderia encontrar alguma restrição. Mas eu nunca encontrei, sabe por quê? Porque a entidade quando incorpora sai de lá de dentro, vem aqui fora, me pega e me chama, me conduz lá para dentro. Eu entendo que isso seja um reconhecimento da minha feminilidade. Não digo que seja uma aceitação e sim um reconhecimento. Quem está me vendo erradamente, erroneamente, ou não está aceitando eu ser mulher, são as pessoas. Ou seja, a vida, a essência da Natureza porque o Candomblé é isso; ou os representantes de Deus ali incorporados, são que estão dizendo: "Não! Tragam essa garota para cá. Ela é uma mulher e tem que estar aqui!"

Maga Patalógica é moradora da uma cidade da grande São Paulo/SP. Ela tem 39 anos de idade, possui o ensino médio completo e é a única negra das interlocutoras deste trabalho. Ela é mãe de um casal de crianças na faixa etária entre sete e doze anos. É igualmente Mãe de outras/os cerca de 290 filhas e filhos de Santo, direta ou indiretamente ${ }^{188}$. Como Yalorixá ${ }^{189}$, está comemorando as bodas

\footnotetext{
${ }^{188}$ Ela explica que diretamente tem cerca de 90 filhos de Santo. E indiretamente, outros 200 aproximadamente, pois como ela é muito conhecida na religião, alguns pais e mães de santo a chamam para "dividir o Axé" - a força vital que emana de todas as coisas vivas - para auxiliar nas iniciações, obrigações, trabalhos, etc.

${ }^{189}$ Na religião do Candomblé, a Yalorixá, cargo que se traduz como "Mãe de Santo", é a Guardiã dos conhecimentos sagrados dos Orixás e da religião.
} 
de prata (25 anos)no Candomblé que conhece há três gerações por herança materna que se iniciou com a bisavó. A agenda apertada divide cuidando das atividades administrativas e religiosas do terreiro, dos filhos pequenos e da casa em que mora com o namorado e as crianças. Um problema de saúde no quadril tem tomado às atenções e limitado um pouco a mobilidade. Numa conversa franca pediu-nosapenas que protegesse os filhos, por isso omitiremos informações e dados mais precisos que num futuro poderiam criar embaraços às crianças.

Nos nossos diálogos, o Candomblé e a autoridade que ela detém junto aos humanos, espíritos e Deuses, assim como as tarefas que o cargo lhe atribui, foram debatidos com grande interesse. A cirurgia de adequação ocorreu há quase cinco anos, realizada no Hospital das Clínicas de São Paulo/SP (HCSP),após uma longuíssima espera de mais de 15 anos (!!!). Outro tema bastante debatido.

Maga Patalógica ou Maga Patalógika é uma personagem de histórias em quadrinhos do desenhista Carl Barks ${ }^{190}$ cujo nome em inglês é "Magica De Spell". Foi licenciada por Walt Disney desde sua primeira aparição na edição em quadrinhos "The Midas Touch" (O Toque de Midas, em português. No Brasil e pela Editora Abril a revistinha se chamava "A primeira moeda do Tio Patinhas") em dezembro de $1961^{191}$ para ser uma das principais vilães de Patópolis, a cidade da família de patos, ao lado dos Irmãos Metralhas e do Sombra.

A anti-heroína de Barks é uma personagem inspirada em diversas referências femininas: da atriz Sophia Loren à Circe a Feiticeira mitológica ${ }^{192}$, passando por Mortícia Adams e a Malévola, a bruxa de contos de fadas na versão dos Estúdios Disney de "A bela adormecida" ${ }^{193}$. Figura de perfil sensual, maligno e inteligente, vive a ameaçar o Tio Patinhas, velho patriarca ricaço e sovina, parente

\footnotetext{
${ }^{190}$ Para saber mais sobre o desenhista, ver em:

https://universodisney2.wordpress.com/tag/maga-patalogica/

Último acesso em: 15/05/15.

191 Ver em: http://ludy-quadrinhosdisney.blogspot.com.br/2010/01/viloes-da-disney.html Último acesso em: 15/05/15.

${ }^{192}$ Ver em: http://sagrado-feminino.blogspot.com.br/2009/10/circe-rainha-das-feiticeiras.html Último acesso em: 15/05/15.

${ }^{193}$ Ver em:

http://www.guiadosquadrinhos.com/personagem/maga-patalojika-\%28magica-de-spell\%29/2395 Último acesso em: 15/05/15.
} 
do Pato Donald e dos sobrinhos Huguinho, Zezinho e Luisinho. No gibi, ela tenta de todas as formas roubar a moedinha número um, para derreter nas lavas do monte Vesúvio em Nápoles, transformando-a num poderoso amuleto que a tornará a pata mais rica do mundo. Possuidora de grande conhecimento em magia tem diversos poderes: transmutação, telecinese ${ }^{194}$, artes boticárias, visões, manipulações e sortilégios.

A sugestão da identificação da interlocutora com a personagem dos quadrinhos foi alegremente recebida pela sujeita, pois das Bruxas aqui narradas, segundo ela própria, é a que leva a vida "na brincadeira".

Conhecemo-nos igualmente na militância dos movimentos sociais de mulheres, assim como Bruxa Malvada do Oeste. Porém, ao contrário dessa última, perdemos um pouco o contato desde 2009. Em 2013, retomamos os debates. Falamos sobre seu o corpo agora já(re)adequado, como ela mesma diz:

Eu sou uma mulher que precisei readequar alguma coisa, ou corrigir alguma coisa que não estava bem.

Tranquila e segura consigo mesma, pode afirmar:

Eu fui ao banco esses dias e eu não consegui passar pela porta giratória.

[...] E eu, tranquilamente, falei: - "Eu vou tirar a roupa!" - Para ver que eu não estou armada, não sou uma mulher bomba. Vamos tirar tudo porque agora estou tranquila, estou segura.

As dificuldades de reconhecimento se deram também no Candomblé, espaço religioso conhecido por sua suposta tolerância com a singularidade humana, porém não com a identidade da Maga Patalógica:

Fui convidada a participar de uma festa de Ogum, chamada de "Feijoada de Ogum".

194 "Telecinese", "telecinésia" ou "psicocinese" é a habilidade de fazer objetos se movimentarem apenas com a força da mente. Para muitos, tais habilidades não passam de embustes, pois desafiariam diversas leis físicas. Ver em: http://pt.wikipedia.org/wiki/Telecin\%C3\%A9sia

Último acesso em: 15/05/15.

Para outros, sobretudo os seguidores dos fenômenos da paranormalidade, são perfeitamente possíveis e, inclusive, apreensíveis por técnicas específicas.

Ver em: http://pt.wikihow.com/Desenvolver-Telecinese

Último acesso em: 15/05/15. 
[...] Quando eu cheguei lá, foram chamadas apenas as mulheres de cargo para poder dançar. E aí um grupo de gays queria que eu não dançasse porque eu sofria dessa suposta transexualidade.

[...] Daí, os Oguns começaram a incorporar. E eles foram incorporando, incorporando. E incorporou o Ogun do dono da festa, do dono dessa Casa, o Ogum de um homem heterossexual. E Ogum é um Orixá muito preconceituoso, um Orixá masculino, arredio. E Ogum virou ${ }^{195}$. Quando terminou de virar já veio, já botou a cabeça nos meus pés. Abraçou-me. Convidou-me para trocar a roupa dele, para ajudar a colocar os adornos dele. Então, assim, se eu sou aceita por Ogum, né? Quem são as pessoas para me julgar?

[...] Mas aí, você já tem que saber que foi assim: no carão, curta, grossa! - "Olha, se não me aceita, não pertenço mais aqui!" Porém a construção foi longa...

Em relação à família mais próxima e à ancestralidade, o reconhecimento da identidade parece ter sido menos tortuoso:

E ai os meus mais velhos viraram para mim e me disseram: - "Maga, a gente conhece você desde que você nasceu. E desde que nasceu já era uma menina. Quem hoje diz que você não era, são pessoas que querem fazer mal a você. Têm algum despeito ou alguma coisa contra a sua pessoa!"

A negociação dos critérios para a cirurgia envolveu algum nível de abdicação dos valores próprios. Entretanto, nessa luta a interlocutora afirma que não negociou sua identidade.

[...] Um dos grandes motivos pelo qual não me operei antes é que eu não aceitava e não aceito até o hoje o termo "transexual", né? "Transexual", "transexualismo" ou "transexualidade" não importando o sentido, não me representa. Não sou eu!

A questão sobre "mulher trans", ou simplesmente "trans", Maga utiliza para explicar alguma diferenciação de ordem física quando adoece, para a solução de algum problema de saúde. Ou para contribuir com os debates sobre o que se chama de transexualidade, adaptando o conhecimento à forma de compreensão da plateia, em palestras ou entrevistas.

[...] Se fala muito sobre trans. Que trans tem que ter visibilidade, que trans isso, trans aquilo, trans aquilo outro. Eu costumo dizer, eu não sou uma mulher trans. Eu sou mulher. O "trans" é quando eu estou

\footnotetext{
${ }^{195} \mathrm{O}$ mesmo que incorporar: afastar a consciência individual ou permitir que seja afastada, para que uma energia espiritual controle o corpo por algum tempo. Vulgo medium.
} 
no médico, ou quando eu dou esse tipo de contribuição, falando da questão da transexualidade. Fora isso a vida é comum!

Para essa filha de Yansã ${ }^{196}$, o olhar do outro enxerga inadequadamente algo muito simples:

Eu acredito que o ser humano vê muito esse sexo biológico de nascimento e não o teu "eu" verdadeiro. Porque se vissem essas supostas pessoas transexuais como elas realmente são, nunca as intitulariam de transexuais: - "Olha, você é mulher! Vamos tirar o pênis e acabou!"

Assim, como as demais interlocutoras, a "transexualidade" para essa bruxa é uma correção física, uma situação passageira. Para melhor compreender do que se trata, ela compara a cirurgia de adequação genital a uma extração dentária:

Foi como se eu tivesse extraído um dente (risos)!

A nomeação das pessoas na categoria "transexual" ocorre, segundo ela, por questões financeiras e, também, algum nível de controle de qualidade das cirurgias.

Do ponto de vista dos médicos, creio que seja uma questão financeira. Ou seja, eles ganham uma nova verba pela transexualidade. Se somos mulheres antes da cirurgia, eles vão apenas administrar o montante de verbas que eles já têm normalmente.

[...] E também, acho que não teria tanta qualidade... Hoje já não tem tanta, né? Se não fosse algo tão especializado, se não houvesse algum controle, qualquer um [cirurgião ou médico] poderia operar, o que derrubaria os preços e a qualidade ou funcionalidade das cirurgias.

Os filhos, a família e os relacionamentos têm grande importância na vida de Maga. Os cuidados familiares aparecem em diversos espaços e papeis sociais, como: mãe das crianças; cuidadora responsável pela avó; nos manejos dos preceitos para a conservação dos Orixás familiares e agregados (os Orixás dos seus filhos de santo).

\footnotetext{
${ }^{196}$ Yansã, lansã, Oyáou Oiá é um Orixá feminino sincretizada no Brasil com Santa Bárbara. Deusa dos ventos e das tempestades é muito conhecida por sua personalidade forte, ousada e guerreira.
} 
Ser Mãe de Santo implica em diversas atividades que Maga administra e executa diariamente, pois o encargo traz enormes responsabilidades:

A partir do momento que eu me tornei Sacerdotisa, que eu me tornei Yalorixá, ficou-me incumbido cuidar dos Orixás do Candomblé. Cuidar com certos segredos que as outras pessoas não têm e com uma dedicação que as outras pessoas não dão. São estudos e mais estudos. Conhecer a palavra do Orixá, a fonética. Aprender como ele gosta de ser tratado. Como ele gosta de ser cultuado.

[…]São mil segredos que somente as Yalorixás (as Mães de Santo), detêm. As pessoas trazem os seus santos para cuidarem. Automaticamente esses santos acabam ficando em minha casa. Ficando em minha casa eu tenho de zelar por eles, pela energia deles. Então, de segunda a segunda: acordar cedo; colocar vela; trocar a água; fazer determinada reza. Aí, no mês "x" faz essa reza, no mês " $y$ " faz aquela reza. Na época de outubro, batem-se chifres. $\mathrm{Na}$ época de julho, rodam um chocalho que imita o barulho do trovão. E assim consecutivamente. Eu sempre digo que mãe de santo tem que ser completa.

Os preconceitos e as dificuldades de compreensão com essas questões que se chama de "transexualidade" - completamente distintas das demandas dos grupos LGBTTT -produzem confusões e dissabores:

Eu imagino que o que mais doa neles [os LGBTTTs] é que as mulheres como eu querem e procuram o anonimato. Já eles e elas querem essa visibilidade "trans".

[...] Imagine! Eu no Candomblé, no meio do machismo. Com essa "sopa de letrinhas" todinha lá: gays, lésbicas, travestis, etc.. E todo mundo olhando para mim: - "Aquela dali é louca, coitada! Ela pensa que ela é mulher..."

Com relação às mulheres que nasceram com vagina, Maga Patalógica não vê quaisquer diferenças, exceto 0 tempo perdido de descobertas e possibilidades sem a genitália que sempre quis ter. As mulheres de fato são também, para ela, mulheres que perderam tempo ${ }^{197}$.

Diferencio sim o tempo que eu perdi. Porque elas brincaram enquanto criança, tendo uma vagina e eu não tive essa descoberta ainda criança. Eu vivia brigando no meu grupo de psicologia [grupo terapêutico no Hospital de Clínicas de São Paulo] e eu dizia sempre: - "Gente, essa cirurgia quanto mais cedo melhor!" Olha o quanto eu perdi. Eu não tive meu baile de 15 anos. Não que não tivesse

197 Relembrando: para Bruxa Malvada do Oeste, são "mulheres sem negrito, sem aspas, sem sublimando". Para Úrsula - A Feiticeira do Mar, mulheres "que nasceram sem bula". E para Maga Patalógica "mulheres que perderam tempo". 
menstruação, mas eu não tive meu primeiro contato com a minha vagina ainda na adolescência quando eu tive meu primeiro orgasmo. Então, eu perdi muito! A única coisa que me diferencia é isso: o que elas viveram antes de mim, o tempo perdido!

Esse ponto de vista, quanto à precocidade dos esclarecimentos e da realização da cirurgia é compartilhado por todas as interlocutoras dessa dissertação e, acreditamos, por grande parte das sujeitas que demandam adequação das genitálias e alterações de prenome e gênero.

\section{Discussão teórica: Gênero, sexo, afeto e sexualidades no Xangô de Recife.}

Existe uma diversidade de cultos e práticas nos vários tipos de religiões vinculadas ao Candomblé no Brasil ${ }^{198}$. Para cada uma deve haver sistemas de representações sobre o universo de manifestações de gênero/sexo e sexualidades entre as e os praticantes e as Deusas e os Deuses.

As questões envolvendo gênero/sexo, identidade e sexualidade em grupos praticantes das religiões de matrizes afrobrasileiras têm certamente uma literatura extensa, pois é conhecida a fama desses cultos no acolhimento do que se poderia chamar de diversidade sexual"199 . Rita Segato (1985), no artigo "Inventando a natureza: família, sexo e gênero no Xangô de Recife" analisa as relações que define como "libertárias" entre as "categorias de parentesco, de personalidade, de gênero e sexualidade das determinações biológicas e biogenéticas" nas representações coletivas e organizacionais dos membros componentes dos cultos Xangô de tradição Nagô em Recife/PE (: 11-12).

\footnotetext{
198 No Brasil há três principais Nações em razão das dinâmicas escravistas que nomeiam e identificam as diversidades de cultos. São elas: a Jeje, a Ketu e a Angola. Há diversas referências em blogs virtuais, num dos quais, encontramos muitas informações sobre cada uma daquelas. Ver em: http://mariabessem.blogspot.com.br/2012/08/as-tres-nacoes-de-candomble-jeje-ketu-e.html Último acesso em: 15/05/15.

${ }^{199} \mathrm{O}$ advogado militante e Doutor em direito pela PUC/SP, Dimitri Nascimento Sales, no prefácio da obra "Diversidade sexual e inclusão social: uma tarefa a ser cumprida" dissertação de mestrado do também advogado Assis Moreira Silva Junior, alerta que "defender a diversidade sexual implica assumir intensa batalha pelo corpo, pelo direito à identidade, pela expressão dos desejos e comportamentos decorrentes da livre vivência das sexualidades" (2014: 15). Também em sua tese de doutoramento, "Diversidade sexual, proteção constitucional e controle de convencionalidade", apresentada à PUC/SP em 2014, Sales trabalha os conceitos de diversidade sexual e sua aplicabilidade no contexto constitucional brasileiro.
} 
Nesse esforço, a antropóloga privilegia o que nomeia como "princípio de indeterminação biogenética", bem como as concepções de casamento e de laços familiares, destacando-os e numerando-os:

1) $\mathrm{Na}$ prática de atribuir 'santos-homem' e 'santos-mulher', indistintamente, a homens e mulheres como tipos de personalidade; 2) no tratamento dado pelos mitos aos papéis femininos e masculinos dos orixás que formam o panteão e às relações que estes mantêm entre si; 3) na visão crítica dos membros com relação aos direitos derivados da maternidade de sangue ou biogenética; 4) na importância à família fictícia que é a 'família de santo' e à adoção de 'filhos de criação', em detrimento do parentesco baseado em laços de sangue; 5) na definição dos papéis masculinos e femininos dentro da família de santo e 6) na bissexualidade da maioria dos membros masculinos e femininos do culto, assim como nas noções relativas à sexualidade que se revelam no discurso e na prática. (: 12).

A cada um dos tópicos acima, Segato explanará o quão peculiar são as formas de construção da identidade individual e das representações grupais na comparação com a realidade brasileira mais geral, estabelecendo uma correlação entre as constituições sociais dos cultos a Xangô com as migrações escravocratas ocorridas no Brasil nos primeiros séculos da era colonizadora.

Sobre os orixás, a autora explica as relações de equivalência entre a personalidade do filho de santo e o santo principal - o "dono da cabeça" -atribuído aquele, baseado na observação dos comportamentos similares que ambos comungam. Esse orixá pode ser tanto masculino quanto feminino e não guarda relação com o gênero/sexo ou sexualidade do filho ou da filha de santo. Naquela etnografia, os santos masculinos são descritos como "'autônomos' ${ }^{\text {,200 }}$ na maneira de agir, e os 'santos-mulher' como 'dependentes'” repetindo os estereótipos de gênero. Para complementar, há a definição também do santo "ajuntó", ou segundo orixá, que fará par com o santo de cabeça nos caminhos de vida da filha ou do filho. (: 14-15). De acordo com os estudos da autora, é sempre melhor possuir um santo masculino e um feminino do que dois do mesmo gênero (NR: 15).

Nas relações de parentesco, Segato afirma que há a relativização da família consanguínea, legítima e patriarcal, característica da formação brasileira da época, em prol da família verdadeira, de santo(fictícia) e matrifocal, instabilizando

\footnotetext{
${ }^{200}$ A autora explica que se refere à autonomia como "a capacidade de tomar decisões e resolver problemas sem necessitar de orientação e estímulo externo [...]” (: 15).
} 
também os papeis de mãe e de pai "convencionais" nas mitologias dos orixás adotadas no Xangô de Recife. Dessa maneira, existem diversas composições familiares na hierarquia e coabitação entre mães e pais de santos e seus filhos e filhas, tanto consanguíneos, quanto de santo. O mesmo se passando com as parcerias afetivo-sexuais das mães e dos pais de santos que podem ser hetero, homo ou bissexuais. Para a autora, a bissexualidade "pareceu a orientação predominante entre os membros do culto [...]"(: 22-24). Advoga então pela negação do matrimônio "como instituição central na organização social", bem como da "irrelevância das determinações biológicas na definição dos papéis sociais dentro da família de santo, em oposição ao forte determinismo biológico que rege a definição dos papéis rituais" dos membros daquele culto (: 28).

Nesse sentido, após os rituais de iniciação das filhas e dos filhos de santo, os laços de solidariedade, obediência e respeito são direcionados às mães e aos pais, bem como às irmãs e aos irmãos "fictícios". A família "legítima", de sangue, estará relegada a uma posição secundária, sendo substituídos em todas as prerrogativas pelos primeiros, relativizando os fatores biológicos. Igualmente, jamais haverá superposição entre o parentesco religioso e o legítimo. Tal regra vale para maternidade e paternidade de santo em relação aos filhos biológicos, cônjuges, companheiros (atual ou anterior), pais e mães legítimos e proibições de relações afetivo-sexuais entre mães e pais de santos e seus filhos de santo. Porém, não há regras entre uma mãe e um pai de santo quando trabalhem juntos numa iniciação, não importando se têm ou não algum parentesco de sangue (:29).

As regras de solidariedade são enfatizadas verticalmente no que tange à mãe ou ao pai de santo e suas filhas e filhos, podendo um filho contar, em caso de necessidade, com a ajuda de "qualquer dos dois lados (de qualquer uma das suas famílias fictícias de orientação)" (: 30-31), com estratégias, em caso de denegatória, de punições às desobediências da vontade dos orixás, formando uma rede de colaboração cujo objetivo é "expandir constantemente e preservar a rede de relações fictícias como recurso de sobrevivência" (idem).

Mais a frente, a autora traz um dado interessante: se por um lado, o gênero/sexo pré-determinado não afetaria à identificação com o santo; por outro, as atividades rituais serão "estritamente distribuídas de acordo com o sexo da pessoa". 
Segato afirma: "na esfera ritual, as categorias naturais de macho e fêmea adquirem uma significação de que carecem em todas as outras esferas de atuação" (: 32). Assim, cita as atividades em que somente os homens atuam: sacrificar os animais dedicados aos orixás; fazer incisões na pele dos filhos e filhas de santo; raspar a cabeça dos iniciados; entrar na habitação onde os espíritos dos mortos residem; dentre outras. Já as mulheres, cujos papeis são "indispensáveis e complementares aos masculinos" executam tarefas domésticas de maneira ritualísticas e ainda devem: assistir à mãe ou ao pai de santo nas necessidades dos cultos; cuidar das pessoas em estado de possessão e preparar as comidas ofertadas aos santos (idem). As mulheres não podem: receber o orixá em possessão ou entrar no "quarto do santo" menstruadas, o que para a autora confirmaria os "fundamentos 'naturais' das categorias enfatizadas pela ordem ritual" (: 33$)$.Em outras palavras, situa aquele universo:

O ritual aponta para a natureza como um horizonte de referência imutável, mas o faz para contrastá-la com a fluidez das opções humanas: macho e fêmea são fatos da natureza e como tais contam no ritual, mas se tornam irrelevantes no mundo humano da cultura, quer dizer, nos papéis sociais, na personalidade e nas preferências sexuais (idem).

Sobre a "transexualidade", a autora se limita em algumas linhas a diferenciá-la da homossexualidade masculina, afirmando certa essencialização da personalidade, papeis e sexualidade tomados "em bloco" naquela categoria.

Na verdade, a transexualidade só pode existir no seio de uma visão de mundo onde os atributos do gênero feminino, assim como os do masculino, são concebidos em bloco, isto é, onde personalidade, papel social e sexualidade estão indissoluvelmente vinculados a um ou outro gênero (: 36-37).

Quanto à identidade pessoal, afirma que dentre os membros estudados há em certa medida uma "mobilidade de gênero", significando que os indivíduos têm ao seu dispor, a depender da situação, diversos componentes de gênero formadores de sua identidade, transitando fluidamente de uma categoria a outra de gênero (: $50)$.

Para concluir, a antropóloga atesta em seu estudo que: 
Com sua relativização do biológico e seu peculiar tratamento da identidade de gênero, os membros do Xangô postulam a independência da esfera da sexualidade, deixando transparecer a premissa implícita na fluidez e liberdade do desejo humano, só com dificuldades subordinável a categorias essenciais ou identidades rígidas $(: 51)$.

Embora a variação religiosa do Candomblé a qual Maga Patalógicadescende não seja a mesma da descrição etnográfica de Segato, servemnos para destacar algumas questões sobre a temática de gênero, sexo, sexualidade e parentesco entre os membros das religiões de matrizes afrobrasileiras o que se procurará realizar com as cenas de vida da interlocutora.

\section{Cenas de vida.}

Maga Patológica responde às perguntas com narrativas evocadas da memória. Assim como nas interlocutoras anteriores, as histórias são narradas não exatamente com o objetivo de responder ao questionário, mas reavivar emoções, buscar outros sentidos para a experiência de vida. A entrevista de cerca de duas horas e meia foi realizada numa das praças ao ar livre do Hospital de Clínicas de São Paulo/SP(HCSP), pois Maga Patalógica havia acabado de ter consulta médica para tentar resolver um problema no quadril. Não nos foi possível acompanhá-la em casa ou nas atividades do terreiro por incompatibilidade de agendas e dificuldades logísticas, já que ela reside a uma hora e meia do centro da cidade. Outras entrevistas foram feitas via aplicativo de celular ${ }^{201}$ para explicitar melhor alguns pontos não abordados suficientemente durante a conversa presencial. De todo modo, procurou-se aproveitar grande parte das entrevistas, modificando-se o mínimo possível para não perder a originalidade da fala.

\footnotetext{
${ }^{201}$ Após ouvir a gravação presencial, foi necessário complementar a entrevista com as perguntas que ficaram pendentes, bem como precisar alguns pontos já respondidos. Assim, gravamos as perguntas faltantes em arquivos de áudio no aplicativo de voz instalado no celular e a interlocutora as respondeu da mesma forma.
} 


\section{Mulher completa.}

Sentadas em uma das praças internas do Hospital de Clínicas de São Paulo, Maga mostra-me a foto do seu documento de identificação (registro civil), com seu nome e fotografia, enquanto conversávamos sobre questões corporais e jurídicas.

Estava até comentando com uma amiga. Eu falei que antes eu já me sentia mulher, só que não era completa. Porque eu não era completa? Por que eu não me sentia? Não! Porque eu entendia que o outro, quando ele falava mal de mim, quando ele queria me agredir, me zoar, me esculhambar de qualquer maneira. Enfim, ser inimigo de alguma forma, ele utilizava o meu corpo que para ele não era completo, para mostrar para mim e para o mundo que eu não era mulher, mesmo eu sendo. $E$ fazendo a cirurgia, hoje eu tenho o prazer de parar na frente do espelho e falar assim: eu não tenho mais aquilo que me causava mal. Além de eu poder hoje gozar em paz. Porque antigamente eu gozava, só que às vezes, eu ficava até com certa depressão, por ter feito aquilo dali (se masturbar ou fazer sexo). Não tem nem como explicar... Se eu fosse um ser humano coerente, eu diria que é melhor não operar, para não passar por todos esses riscos, né (perder a capacidade de gozar) ? E viver a vida do jeito que eu estava. Aliás, ao invés de deixar o cabelo crescer, cuidar da pele, fazer plástica e isso e aquilo. Eu poderia ter tomado anabolizantes, ido para uma academia, ficado um homem musculoso...Só que a minha identidade não era essa. Eu nunca conseguiria viver de terno e gravata. Nunca conseguiria! Eu tenho dois bebes, acho que eu não seria eu se fosse chamada de pai. E o maior prazer do mundo é me olhar no espelho e saber que sou mulher!

\section{“Não tem trans! Não tem isso!”}

Eu fui ao banco esses dias e eu não consegui passar pela porta giratória. A porta deu problema, deu problema e deu problema. E eu tranquilamente, falei: - "Eu vou tirar a roupa!" - Para ver que eu não estou armada, não sou uma mulher bomba. Vamos tirar tudo porque agora estou tranquila, estou segura. E dá a impressão... Ninguém viu minha vagina ou ninguém me vê nua para saber que sou mulher e ela não foi feita na minha cara. Mas hoje quem conversa comigo aceita a mulher que 
chega. E antes da cirurgia não era aceita. Eu acho que tinha algo incutido em mim que não me trazia essa plenitude da feminilidade. Hoje eu tenho! E nem eu mesma questiono se eu sou mulher ou não. Por isso que eu digo que se fala muito sobre trans. Que trans tem que ter visibilidade, que trans isso, trans aquilo, trans aquilo outro. Eu costumo dizer: eu não sou uma mulher trans. Eu sou mulher. O "trans" é quando eu estou no médico, ou quando eu dou esse tipo de contribuição, falando da questão da transexualidade. Fora isso a vida é comum! Quando eu chego à escola para pegar meu filho, ninguém fala: - "Olha! É porque a mãe é trans" - "Lá vai a mãe trans!" - "Ah! Feliz dia das mães trans!" - Não! É comum! Quando meu filho me abraça e fala:- "Mamãe, eu quero sucrilhos! Mamãe, eu quero Danone!" Não tem trans! Não tem isso! E a troca do amor também, não tem isso. Quando você vai comprar pão: - "Dois pãezinhos para a trans." Não tem isso! O que eu sempre quis, por isso estou tão realizada, tão feliz comigo, é porque eu queria isso: essa certeza de que sou mulher. E ponto! Daí, as outras discrepâncias do que a gente vai viver: do preconceito masculino; ou do preconceito de raça, porque eu sou negra; ou do preconceito religioso, porque eu sou candomblecista, são outras coisas.

\section{Ser mulher na religião do Candomblé: a essência do ser humano.}

Maga Patalógica nasceu e cresceu sob as regras sócio-religiosas do Candomblé em uma das suas Nações ou tradições predominantes, conhecida como Ketu. Como visto com Segato, as relações de sociabilidade sobre as questões de gênero, sexo e sexualidades ocorridas em muitas religiões de matrizes afrobrasileiras, inclusive no Candomblé de Ketu, são distintas daquelas encontradas na sociedade brasileira mais ampla.

$\mathrm{Na}$ experiência de vida de Maga, a trajetória singular precisou ser compreendida pelos familiares para haver a adaptação aos preceitos da religião. Assim, gênero, genitália, expressões da identidade e sexualidade, todos em conformidade com seu entendimento sobre si mesma, foram conquistas quotidianas.

O que mais se discute dentro do Candomblé, das religiões de matrizes africanas com relação à transexualidade é a essência do ser humano. Porque eles entendem que o homem tem uma essência, por ter pênis e por ser homem e blá, blá, blá e a 
mulher por ter vagina e blá, blá, blá, é outra essência. Por isso muitas pessoas do Candomblé dizem que uma mulher que passa por questões de transexualidade nunca será uma mulher dentro do Candomblé. Ela só será mulher fora do Candomblé. Perante seu Orixá ela continuará sendo homem, pois é a essência dela. Para poder compreender essa dinâmica, eu tive que vivenciar. Porque quando eu nasci, o médico viu que eu tinha pênis e entendeu então que eu era homem e falou para todo mundo que eu era homem. E daí, eu me iniciei no Candomblé aos 13 anos de idade. Quando eu me iniciei eles entendiam essa dinâmica de que esta essência era masculina(aponta para si mesma). E não é verdade! Mas quando eu inteirei 15 anos de idade, aconteceu aquele "bug" todo. Eu disse: - "Gente, para tudo!" Quero descer desse bonde porque ele é masculino. Ele não me pertence! Eu não vou ficar aquil'Se Deus não me aceitar, o problema é dele! Se os Orixás do Candomblé não me aceitarem o problema é deles! E aí os meus mais velhos viraram para mim e me disseram: - "Maga, a gente conhece você desde que você nasceu. E desde que nasceu você já era uma menina. Quem hoje diz que você não era, são pessoas que querem fazer mal a você. Têm algum despeito ou alguma coisa contra a sua pessoa!"

\section{Conguinha laranja.}

Porém desde criança tive problemas. Na creche, aos quatro anos de idade... Porque eu fiz creche numa chácara comandada por padres católicos, então na hora de brincar, os meninos brincavam de um lado, as meninas brincavam do outro. Eu me recusava a brincar na ala dos meninos. Eu queria a casinha das meninas, as bonequinhas, etc. Outra questão: minha prima ia de saia pregueadinha e eu tinha de ir de terninho. E aí, foi a minha morte, porque eu queria a saia dela. Não foi possível. Aí, minha mãe, muito sábia, negociou comigo porque as meninas usavam um têniszinho, daquele do estilo conguinha, parecendo um "All Star". Eram laranja os sapatos das meninas e era muito difícil de encontrar. Minha mãe encontrou e falou: "Tudo bem! Você não pode ir com a sainha pregueadinha, mas você vai com esse sapatinho!" E eu consegui ir. Porém, eu não tinha problema em usar o sapato do terninho. Porque tinha um salto e quando eu andava ele fazia "toc, toc, toc", eu me sentia de salto alto como minha mãe(risos). 


\section{Identidade feminina construída no Candomblé.}

Mas enfim, que bom que eu iniciei o Orixá no meio de pessoas que me viram nascer. E elas puderam atestar essa feminilidade que eu já tinha desde o berço, que é assim que eles sempre disseram de mim. E eu disse: se eu não puder ficar na religião, se os Orixás não me aceitarem, eu saio! E eles não queriam me perder, nem tanto os Orixás. Aliás, algumas pessoas me perguntaram: - "O que você acha que o seu Orixá vai dizer na hora que você fizer uma cirurgia de 'mudança de sexo'?" E eu disse: - "Eu acho que não vai dizer nada. Se ele é um Orixá e conhece meu passado, meu presente, meu futuro, sabe como eu nasci e como eu ficarei no futuro. Então, acho que não vai ter problema!" Aí, eles refletiram: - "É realmente! Vamos deixar a Maga usar uma saia dentro do Candomblé para ver como o Orixá dela vai se portar..."E aí foi normal, foi tranquilo. Então, desde os 15 anos eu tenho essa identidade feminina construída no Candomblé. Ela não veio agora.

Quando eu incorporei de Orixá depois da cirurgia foi normal. Como eu sempre incorporei. Foi como se eu tivesse extraído um dente!(risos)Porque eu só esperei meu restabelecimento. Logo em seguida, teve uma grande atividade que eram os 40 anos de uma Mãe de Santo muito famosa. Eu estava lá e só foram chamadas as pessoas mais importantes dentro do Candomblé para incorporar. E eu fui uma das convidadas, entende? Nem me lembrava de que estava operada e acabei incorporando. Eu comparo com a extração de um dente! Então, tem um preconceito contido nessa tal essência do ser humano...Mas aí, você já tem que saber que foi assim: no carão, curta, grossa! - Olha, se não me aceita, não pertenço mais aqui. Porém a construção foi longa...

\section{A (enorme) espera pela cirurgia.}

Essa interlocutora, como diversas sujeitas, foi submetida a uma espera muito longa do momento em que entrou com sua demanda de cirurgia de adequação genital no ambulatório de endocrinologia do Hospital de Clínicas de São Paulo (HCSP) até o dia da efetiva intervenção. Tal demora se deu, segundo ela, dentre outros fatores por "negligência e falta de sorte". Porém, como se verá no último capítulo com a trajetória de Malévola, fatores como preconceito, jogos de 
poder, desorganização, desinteresse e má-gestão estatal e até maldade, fazem com que elas esperem muitos, muitos anos.

Quanto à Maga, disse-nos que entrou no "tratamento"(com aspas, pois para ela, assim como para as demais interlocutoras desse trabalho, não se trata de

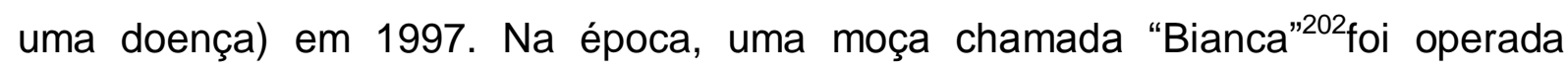
legalmente no Brasil com grande alarde da mídia. Um amigo que trabalhava no HCSP a ajudou a chegar ao ambulatório de endocrinologia, cuja chefa é uma psicóloga de renome nacional ${ }^{203}$. Nos primeiros dois anos, ela insistia muito pela cirurgia. Nessa época havia uma fila grande de moças como ela esperando, porém as intervenções eram custeadas por "subsídio"204. Maga Patalógica afirma que sua historia era "muito redondinha", chamando a atenção da psicóloga-chefe e dos endocrinologistas no interesse em ajudá-la.

Fiz a primeira triagem e elas pareciam gostar do meu caso. Era "muito redondinho":disforia de gênero; traços femininos; já vivia como mulher; estava numa identidade em construção; não tocava na genitália, etc. Tinha até dificuldades na higienização do órgão (o pênis). Desde aquela época eu já adorava sexo. Hoje plenamente, né? Porém, eu ficava em depressão sempre que gozava. Durante um ano fui testada de todas as maneiras. Tive que contar minha história quinhentas mil vezes. Tive que relatar com minha escrita de punho. Tinha de relatar para as

\footnotetext{
${ }^{202} \mathrm{~A}$ interlocutora se refere à Bianca Magro que em 1998teria sido a primeira "paciente" a fazer a cirurgia legalmente no Brasil pelo Serviço Público de Saúde, no Hospital das Clínicas da Universidade Estadual de Campinas (UNICAMP).Sobre ela, encontramos apenas referências sensacionalistas, como a entrevista concedida à Revista Trip em abril de 1998. Ver em:

https://books.google.com.br/books?id=Fi0EAAAAMBAJ\&pg=PT7\&lpg=PT7\&dq=bianca+magro\&sourc e=bl\&ots=-wttnx2KF2\&sig=gKe8BjXNA5SJGqb0UcApD5j7Cow\&hl=pt-

BR\&sa=X\&ei=UTogVeC0C8ebNtHSgMgF\&ved=0CC4Q6AEwAw\#v=onepage\&q=bianca\%20magro\&f =false

Último acesso: 15/15/2015.

${ }^{203}$ Como dito anteriormente, omitimos propositalmente o nome das e dos médicas/os e demais "especialistas" nesse trabalho, para que as interlocutoras pudessem falar livremente sem receios de represálias.

${ }^{204}$ Quando a interlocutora usa o termo "subsídio" não se deve ter em mente a acepção meramente econômica da palavra. Como visto no capítulo primeiro, antes de 2008 as cirurgias de adequação não estavam inseridas nas grades de despesas do SUS, por isso, apesar da iniciativa do Hospital de Clínicas de São Paulo, da UNICAMP e de Porto Alegre, as cirurgias não tinham verbas regulares, mas pequenas remessas de valores despendidos pelo Governo Federal nas rubricas de pesquisa que eram então repassadas aqueles hospitais e/ou universidades. Na narrativa da Maga Patalógica, além desse "subsídio", os médicos impactados pela situação das pacientes custeavam eles próprios algumas cirurgias. Em seguida a interlocutora falará mais sobre isso.
} 
pessoas e elas iam anotando. Fiz testes sanguíneos para encontrar os cromossomos e exames de cariótipos ${ }^{205}$ diversas vezes. A pretexto de definir a minha personalidade, fiz vários desenhos: desenhos da família; de bichos; de flores e árvores. Tudo que você possa imaginar ${ }^{206}$. Fui submetida a uma espécie de "terapia de confronto", na época eu disse isso para minha psicóloga, porque tudo que eu dissesse por mais correto que fosse, eu era confrontada para ver se tirava alguma máscara e me revelava ser uma outra pessoa. Eu me lembro de dizer isso para ela: - "Você fica me confortando como se você quisesse que eu tirasse uma máscara e virasse outra pessoa. Mas tudo que eu disse no 'tratamento' foi a minha verdade!"

Minha única mentira no "tratamento" é que eu tinha ouvido uma conversa entre o pessoal do hospital nos corredores: - "Dessas daí, só ganha a cirurgia as que são mais sofridas, as mais burrinhas". E desde o princípio, eu sempre tive uma personalidade forte. Sempre lutei muito pelos meus objetivos e nunca me predispus a ficar sofrendo, choramingando, me martirizando. Eu venho de uma família de mulheres e sempre faltaram homens para nos ajudar. E a gente acabava tendo de suprir as necessidades, até as masculinas, né? Eu nunca fui sofridinha, frágil. E aí um dia tinha um teste de QI. E umas classificações estranhas, tipo assim: QI até tanto não poderia ser "transexual"; QI até tanto estava em descoberta de si; QI até tanto, era mega, ultra, "supertransexual". Mas como eu ouvi lá fora que as mais sofridinhas, as mais burrinha se digamos, as mais loucas, malucas (as que corriam

${ }^{205}$ Exame genético realizado com células do sangue ou outras partes do corpo para detectar diversas anomalias, inclusive as sexuais. Aqui, são utilizados para descartar a intersexualidade (chamada pelas ciências médico-psicológicas de: hermafroditismo).

\footnotetext{
${ }^{206} \mathrm{Um}$ dos testes utilizados pelos "especialistas" para identificar uma possível candidata à cirurgia é a "Técnica Projetiva do Desenho" ou "HTP", ou ainda no jargão psicológico "Casa-Árvore-Pessoa", em que a sujeita é instada a desenhar uma casa, uma árvore e duas pessoas: uma à escolha da sujeita e a outra necessariamente do gênero/sexo oposto ao seu. Ao que parece esse teste pretende entender a personalidade da sujeita. Outro teste muito utilizado é o "Método Rorscharh". De acordo com um site de informações básicas sobre psicologia, esse teste de avaliação projetiva da personalidade, propiciaria ao profissional daquela área, interpretar "[...] a avaliação quantitativa da inteligência; a avaliação qualitativa da inteligência; a avaliação da afetividade; as atitudes gerais como ambição, sentimentos de inferioridade ou superioridade, agressividade, entre outros; o humor; os traços neuróticos e os indícios de um diagnóstico psiquiátrico". Disponível em:

http://www.infoescola.com/psicologia/teste-de-rorschach/

E também: http://pt.wikipedia.org/wiki/Teste_de_Rorschach

Último acesso em: 15/05/15.

Esses testes estão elencados no laudo de Malévola o qual tive acesso através dela própria. O mesmo laudo foi juntado ao seu processo de alteração de prenome.
} 
maior risco de cometer mutilações ou suicídios)ganhavam as cirurgias mais rapidamente $^{207}$. Fiz o teste de QI e errei em tudo de propósito. A minha psicóloga quando terminou, olhou e falou: - "Hoje você não deve estar num bom dia, porque eu sei que você não teria esse QI. Quero realizar esse teste com você mais duas vezes". Fiquei preocupada com aquilo, mas realizei o teste em duas semanas seguidas, normalmente.

No ano em que completei dois anos passando por essas observações nas Clínicas, teve alguns problemas, pois os grupos estavam lotados e as pessoas não conseguiam fazer a cirurgia. Durante a maior parte da minha espera de 15 anos 0 tratamento era custeado pelos próprios médicos. O governo mandava um subsídio ao hospital para os médicos implantarem as ações que eles consideravam necessárias, mas que não estavam na grade de pagamentos do governo e nem dos doadores do hospital. Havia também um dos diretores do hospital que era solícito a essa causa e ele empregava uma pequena parte para custear as cirurgias de transgenitalização. A psicóloga me relatou há pouco tempo que esse subsídio não dava nem para pagar as medicações que se utilizava na paciente e por isso algumas meninas foram para o grupo de terapia ${ }^{208}$. Ela não quis me colocar no grupo de terapia porque eu tinha uma personalidade muito forte e eu estava totalmente preparada. Segundo eles, me deixaram seguir na vida para ver se eu encontrava uma clínica particular e me operava fora do HCSP, pois nas Clínicas demoraria muito: - "Você está apta à cirurgia. Pode fazê-la onde conseguir, mas aqui não dá para fazer agora porque tem várias outras". Esse foi o argumento dela!

Minha posição na fila era a 15ạ. Havia outras oito meninas já aguardando há 10 anos. Não havia consultas marcadas e a cada ano, eu ligava duas vezes para a psicóloga e insistia sobre a cirurgia. Angustiava-me muito o tempo que se passava

\footnotetext{
${ }^{207}$ Aqui podemos nos lembrar da "transexual verdadeira" cuja personalidade se alinha perfeitamente às expectativas dos "especialistas da vida alheia" e aos compêndios médico-psicológicos. $O$ "padrão transexual" é uma permanente preocupação do poder-saber médico-psicológico e jurídico. Como visto em trechos de Bento e Teixeira consiste em avaliações de diversas naturezas, em alguns casos com o uso de questionários, contendo perguntas objetivas elaboradas propositalmente para se evitar a "falsa transexual", aquela que não merece a cirurgia, pois supostamente além de não ser "autêntica" se arrependeria de haver feito a intervenção num futuro.

${ }^{208}$ No primeiro capítulo abordamos um pouco sobre os grupos de terapia mediados por psicólogos, psiquiatras, assistentes sociais, dentre outros. Lá as candidatas são instadas a debater sobre suas vidas, problemas, dificuldades, enquanto esperam pela cirurgia. Nesses grupos, elas também são avaliadas e indicadas ou não para as intervenções cirúrgicas.
} 
sem nem uma previsão sequer... Minha psicóloga tentava me consolar por telefone. Com cinco anos depois de ter dado entrada no HCSP, eu tive uma dor de estômago muito forte e estava urinando sangue em razão do uso de hormônios. Mas eles me julgavam por tráfico internacional de entorpecentes (risos). Nos exames, eles não podiam continuar receitando os hormônios. Por volta de 10 anos de HC, eu tive uma grande depressão. Era muito sofrimento! Eu já não aguentava mais tanta espera por uma cirurgia. Daí, eu esculhambei a psicóloga! Ela me disse o de sempre: que não poderia fazer nada por mim. E foi por isso que eu entrei na militância para tentar aprovar uma verba vinda da DST/HIV/Aids ${ }^{209}$ que operaria no mínimo cinco meninas por ano. Essa verba ainda levou uns dois anos para sair. Então, a secretária de saúde me avisou que eu poderia retornar ao HC, procurar a psicóloga e, agora com a verba, me operar. Assim, eu retornei quase 13 anos depois ao HC. Mas nessa espera toda, eu tive de insistir muito todos os anos, porque sem isso não teria conseguido a cirurgia pelo HCSP mesmo com as portarias do SUS.

\section{Discordância do termo transexual.}

Um dos grandes motivos pelo qual não me operei antes é que eu não aceitava e não aceito até o hoje o termo "transexual", né? "Transexual", "transexualismo" ou "transexualidade" não importando o sentido, não me representa. Não sou eu!Eu sou uma mulher que precisei readequar alguma coisa, ou corrigir alguma coisa que não estava bem. Assim como uma mulher que tem câncer, o caso da Angelina Jolie ${ }^{210}$, que não chegou a ter o câncer, mas para se prevenir foi lá e reconstruiu a mama e nem por isso ela virou uma terceira pessoa. Eu acredito que a mama é algo erótico e algo que também dá prazer na hora do sexo. E ela não mudou sua identidade. Eu acredito que o ser humano vê muito esse sexo biológico de nascimento e não o teu "eu" verdadeiro. Porque se vissem essas supostas pessoas transexuais como elas realmente são, nunca as intitulariam de transexuais. - "Olha, você é mulher! Vamos tirar o pênis e acabou!" Então, assim, você não olha para uma mulher que teve um

\footnotetext{
${ }^{209}$ Ver: "Plano Integrado de Enfrentamento da Feminização da Epidemia de Aids e Outras DST", Ministério da Saúde, 2007.

${ }^{210}$ Atriz norte-americana que em 2014 retirou as mamas e mais recentemente os ovários para a prevenção do câncer de mama cujo histórico familiar vitimou a mãe da artista e uma tia. Ver em: http://www.bbc.co.uk/portuguese/noticias/2015/03/150324 jolie ovario lab Último acesso em: 15/05/15.
} 
problema de vagina, que fecha o canal vaginal, você não a chama pela doença. Ou pela patologia, ou pelo estigma. Mas essas pessoas que reivindicam cirurgias genitais são chamadas de "transexuais", ou seja, pela doença. E isso sempre ficou latente na minha cabeça. Isso sempre me incomodou. Outra coisa também é a questão da submissão. Isso muito me incomoda até hoje. Porque eu acho que nós não temos de ser submissas a nada. Há uma negociação, né? Por exemplo: - "Olha somos o SUS e não podemos fazer uma cirurgia de retirada de costela para afinar o corpo!" É um desejo que eu tenho de afinar a cintura por essa cirurgia. Mas o SUS não a disponibiliza, então, tudo bem! Mas vamos discutir! Não dá para fazer, não dá!- "Olha, nós temos uma cirurgia de mama..." Isso é uma negociação! Agora: "Você é transexual!"- Não tem negociação, pelo menos para mim! Mesmo na questão dos meus laudos. Eu fui fazer uma cirurgia e estava lá na capa do meu prontuário, e eu vi passar por mim escrito: "transexual" e eu pedi: - "Não! Tira daqui! Tira daquil".

Outra coisa também, no meu laudo consta a minha religião. Quando uma enfermeira sem vergonha de qualquer outra crença vê, ela já vem para cima com o estigma de que eu vivo em pecado, de que eu preciso alcançar a Deus, de que eu preciso buscar um perdão, uma redenção. E quando eu vim fazer a minha redesignação eu me lembro da enfermeira que me acolheu no quarto. Assim que eu cheguei minha primeira triagem foi:

Enfermeira: - "Você já conversou com Deus sobre a cirurgia que você vai fazer? Porque é uma cirurgia muito grande e ..."

Aí eu falei: - "Do que você está falando??"

E ela insistiu:- "Porque você sabe que você vai desfazer algo que o Criador criou..."

E eu: - "Deixa eu te fazer uma pergunta? Você se trata onde??"

E ela: - "Como assim senhora?"

E eu respondi: - "Você deve ser doente! Eu quero que você saia do meu quarto e chame seu superior agora! Deixa-me falar uma coisa para você: eu tenho um problema de buceta. E se eu fosse procurar Jesus Cristo para resolver meu problema de buceta eu estaria na igreja. Mas eu não fui atrás de Jesus Cristo, eu procurei um cirurgião plástico, está bom? Agora fora do meu quarto e não volte mais aqui!"

E veio a supervisora: - "O que aconteceu? A enfermeira disse que a senhora falou um palavrão?!?...” 
Eu: - "Falei! Falei 'buceta' para ela compreender a magnitude da bobagem que ela disse e me deixar em paz. Eu não preciso conversar com Deus. Aliás, ele é que tinha que conversar comigo em e explicar...- 'Olha filha, me desculpa. Saiu errado. Joguei um pó de pirlim plim plim. Deu um efeito colateral e você teve um pintinho e todo mundo te tratou da maneira que tratou. Mas agora você vai fazer essa cirurgia porque eu - Deus - dei a inteligência ao homem para poder consertar um erro meu'!

A enfermeira-chefe ficou aterrorizada e saiu do quarto como se pensasse assim: "Tem uma maluca ali!" Pode ter achado que eu seria uma devota de Satanás. Sei lá o que ela pensou dentro da questão religiosa dela (risos).

\section{Tem sentido para você ter de se identificar como "transexual"?}

Não tem sentido, não! Teria se eu tivesse uma patologia decorrente da cirurgia de transgenitalização. Por exemplo, não posso chegar a um ginecologista e falar: "Doutor, estou com uma dor no colo [do útero]"! Ele vai me examinar, me pedir exames e vai querer que eu explique a ausência do útero, das trompas, etc. Para explicar, vou ter de contar da transexualidade. Ou alguma história ou mentira inventar. Inclusive essa pergunta é muito pertinente para mim. Porque eu tive um problema aqui nas Clínicas. Tive uma infecção urinária e fui a um hospital lá na minha cidade. No hospital, uma das perguntas que o médico me fez, foi: - "Você já fez alguma cirurgia na vagina?" Sem olhar para minha cara, ele não sabia nada de mim. Eu falei: - "Sou operada!" O médico perguntou: - "Como assim?" Aí expliquei tudo para ele. E ele: - "Ah... Eu quero ver". Mostrei e depois ele falou: - "Ahan. Bom, não vou tocar em você porque não é minha área. Não vou tratar você, não! Volte lá no hospital que você fez que eu não vou colocar a mão!" Daí, tive que vir aqui. Quando eu cheguei [no HCPS],o cirurgião falou: - "Pelo amor de Deus! É uma infecção urinária! Trata-se em qualquer hospital. Você não precisava estar aqui!""Mas o medico me mandou vir para cá" - Ele disse: - "Não! Não pode ser assim! Você deveria ter chamado a polícia para ele!" Agora o que eu faço: como já compreendi que uma infecção urinária não tem a ver com a transgenitalização, não falo mais nada! Nunca mais tive nenhuma patologia para procurar um médico. Mas como mulher é uma questão de tempo até adquirir uma bactéria, seja sentando em banheiro público ou fazendo sexo com algum parceiro, né? Não estamos falando de doenças sexualmente transmissíveis, mas bactérias que às vezes estão no pênis do 
parceiro. Então, não tem sentido nenhum se não houver relação com a cirurgia em si.

\section{Qual poderia ser a justificativa médica para nomeá-la como "transexual"?}

Do ponto de vista dos médicos, creio que seja uma questão financeira. Ou seja, eles ganham uma nova verba pela transexualidade. Se somos mulheres antes da cirurgia, eles vão apenas administrar o montante de verbas que eles já têm normalmente. É só para pleitear mais verba. E também, acho que não teria tanta qualidade... Hoje já não tem tanta, né? Se não fosse algo tão especializado, se não houvesse algum controle, qualquer um [cirurgião ou médico] poderia operar, o que derrubaria os preços e a qualidade ou funcionalidade das cirurgias.

\section{Questões de identidade e sexualidade. ("Você se sente mulher?").}

Nas perguntas sobre identidade, Maga Patalógica explicita melhor seus sentimentos em relação a si. A plenitude consigo mesma foi finalizada com a cirurgia. Para ela, a identidade seria uma essência ${ }^{211}$, uma parte mais ou menos estável da sujeita e as modificações corporais serviriam como complemento e, igualmente, para evitar a maldade alheia. Em relação aos outros, ela afirma que está menos susceptível ao olhar de terceiros hoje do que, como visto acima, no passado. Se esses outros forem amigos e familiares, Maga tem tranquilidade para educá-los nas formas de tratamento. Quanto à sexualidade, a interlocutora afirma que não tinha grandes problemas, exceto em ser ativa com o pênis. O exercício e a busca do prazer sexual parecem ser vividos com menos conflitos na atualidade.

Sinto-me mulher sim! Muito! (risos) Completa! Há uma coisa que a gente sente que está contida no olhar no outro, né? Por exemplo, se alguém me pede o RG ou a certidão de nascimento e eu as apresento, não tem o que questionar. Pelo meu perfil físico, pela minha maneira de viver, também não sou questionada. Agora se alguém sabe da minha sexualidade, aí sim, vem essa indagação: - "Você é realmente mulher?" Mas essa é uma indagação do outro, porque para mim eu estou completa e sempre fui mulher. E se o problema é do outro, ele que o resolva!

\footnotetext{
${ }^{211}$ Semelhante posição se encontra na narrativa de Úrsula.
} 
Eu vivo superfeliz hoje! Sou completa! Não existe essa sobrevida e esses problemas todos, não. ${ }^{212}$ Antes de fazer a cirurgia, eu já sentia prazer. Meu único desprazer era ter o pênis. Com a vagina estou felicíssima! E o anal ainda é prazeroso também, apesar de hoje eu não gostar tanto. O que eu sinto na frente me é tão prazeroso que eu não preciso. Quando eu e meu namorado tiramos para fazer aquele sexo enorme, com tudo que a gente tem direito, é muito gostoso! Eu sou louca, alucinada, por beijo grego, né? Tanto em receber como em dar, também. Sempre fui antes da cirurgia. Inclusive alguns homens acreditavam que se eu beijava, eu comia. Mas são coisas completamente diferentes, meu Deus do céu!(risos) E hoje em dia quando falam assim: - "Sexo anal". Eu penso: é Legal. Tudo bem! Mas tem que ter toda essa completude. Se virar para mim e falar assim: - "Vamos que eu quero fazer só um analzinho!" Sei lá, não me completa!

\section{"Porque jamais uma vagina Ihe faria ser mulher!"}

Eu vejo a mim mesma como mulher. Não tenho nada que eu pudesse pensar vou mudar "x" questão para me sentir mais mulher. É legal, nesse sentido, relembrar o caso da Lea $T^{213}$ que falou que fez a cirurgia, mas não estava satisfeita porque ela nunca conseguiria ser mulher pelo tamanho do ombro ou pelo tamanho do sapato 44 que ela calçava. Eu conheço mulheres que tem dois metros de altura, com ombros enormes e que usam roupas masculinas, pois não encontram roupas femininas. $E$ não deixam de serem mulheres porque usam sapato número 46. Elas não perdem a sua identidade. Então, com relação à Lea $T$, a identidade dela está em confronto com ela mesma. Ela tem um problema com ela mesma! Ela tinha que ter se encontrado antes da cirurgia, porque jamais fazer uma vagina Ihe faria ser mulher! Você poderia colocar a vagina na testa ou embaixo do braço, quem você é na essência não vai mudar. Ela pode ser funcional ou não, mas não vai mudar! É que nem um soldado que recebeu um tiro, uma explosão de granada, no pênis e continua homem. Teve o pênis decepado na guerra. Ele tem todos os traumas e sofrimentos desde o incidente, mas não perde a identidade que é de homem. E nós não perdemos a nossa. Nós apenas a encontramos ao longo da nossa vida. Porque

\footnotetext{
${ }^{212}$ Nesse trecho refletíamos sobre os argumentos de senso comum de que a cirurgia de adequação genital na vida das sujeitas funcionaria como um paliativo. Em outras palavras, as sujeitas sobreviveriam e não gozariam a vida, já que jamais se satisfariam pessoal e sexualmente. Entretanto, a fala é em sentido contrário, inclusive quanto ao prazer.

${ }^{213}$ Como visto no capítulo de Úrsula - a Feiticeira do Mar.
} 
quando a gente nasce todo mundo fala: - "Você não é! Você não é! Você não é! Você não é!" Até você conseguir provar para você que você é[mulher], leva um tempo! Até você se encontrar, leva um tempo. Só que também depois que você se encontra ninguém mais te faz recuar!

\section{Ser vista e reconhecida como mulher.}

Eu até desejava antes da cirurgia ser vista como mulher. Hoje já não tem mais o que desejar, é natural! Você entra na padaria: - "Senhora, pois não?!" Uma garrafinha de água! -"Claro, senhora! É ' $x$ ' valor!" Ou, se tem um grosso, um mal-educado: - "Não tem água, não!" (risos)E não tem a ver com você ser mulher ou não. Então, eu desejo ser reconhecida. Porém hoje já não faz mais tanta diferença. Antigamente fazia. Eu precisava muito desse reconhecimento explícito. Hoje, talvez, eu não sei como é com as outras pessoas, mas eu abdiquei de tudo o que negava a minha feminilidade. Eu joguei fora! E eu não tenho contato com isso. Talvez um dia eu possa até ter contato com um tio militar que não foi a favor de mim ou com um primo, mas isso é besteira! Não faço nem questão! E deles eu não quero esse reconhecimento.

\section{Percebe diferenças entre você e outra mulher? (As mulheres que perderam tempo).}

As mulheres que perderam tempo (nascidas com pênis) é a interpretação de Maga em relação a uma possível diferença entre aquelas que "não perderam tempo", ou seja, as que nasceram com vulva e vagina. Ao que parece, nem mesmo aspectos biológicos como menstruar e parir, presentes nas narrativas das demais interlocutoras, é razão de diferenciação entre mulheres.

Olha, na realidade, não! Mas para brincar fazendo uma sátira, sim! Diferencio sim o tempo que eu perdi. Porque elas brincaram enquanto criança, tendo uma vagina e eu não tive essa descoberta ainda criança. Eu vivia brigando no meu grupo de psicologia [grupo terapêutico no Hospital de Clínicas de São Paulo] e eu dizia sempre: - "Gente, essa cirurgia quanto mais cedo melhor!" Olha o quanto eu perdi. Eu não tive meu baile de 15 anos. Não que não tivesse menstruação, mas eu não tive meu primeiro contato com a minha vagina ainda na adolescência quando eu tive 
meu primeiro orgasmo. Então, eu pedi muito! A única coisa que me diferencia é isso: o que elas viveram antes de mim, o tempo perdido!

\section{A ofensa na confusão com transexual (negativa do ser mulher).}

Sinto-me ofendida ao ser reconhecida ou apontada como transexual. Eu acho que as pessoas querem criar um terceiro sexo e não é isso que eu queria. Eu não queria ter sido vista ou compreendida como uma anomalia da sociedade. Ou como algo diferente. Também não quero nunca tomar a identidade de ninguém. Eu só quero viver a minha. E entendo haver dois gêneros: masculino e feminino, o qual você pertence. Eu pertenço ao feminino. Daí, se a precheca [vagina]tem o tamanho da precheca de uma cabra ou de uma vaca, não tem diferença. (risos)É uma precheca! A mesma coisa as mulheres que faziam períneo. Elas são menos mulheres? São mulheres diferentes? A mulher que teve que retirar o útero. Ela é menos mulher? É mais mulher? Vai ser excluída da identidade feminina? Até mesmo dentro da religião do Candomblé, existem o que a gente chama de duas casas: a Casa masculina e a Casa feminina. Quando vai se fazer ritual para as pessoas que já morreram, somente os homens podem participar. E quando vai se fazer ritual para celebrar a vida, somente as mulheres podem fazer. E aí me perguntam: - "Qual Casa você ocupa, Maga?" Eu sempre digo: Eu não sou homem! Jamais poderia entrar na Casa masculina. Mas na Casa feminina eu poderia encontrar alguma restrição. Mas eu nunca encontrei, sabe por quê? Porque a entidade quando incorpora, ela sai de lá de dentro, vem aqui fora, me pega e me chama, me conduz lá para dentro. Eu entendo que isso seja o reconhecimento da minha feminilidade. Eu não digo que seja uma aceitação e sim um reconhecimento. Quem está me vendo erradamente, erroneamente, ou não está aceitando eu ser mulher, são as pessoas. Ou seja, a vida, a essência da Natureza porque o Candomblé é isso; ou os representantes de Deus ali incorporados, são que estão dizendo: "Não! Tragam essa garota para cá. Ela é uma mulher e tem que estar aqui!" 


\section{A dignidade ofendida no acesso não permitido ao passado da sujeita.}

Trazendo novamente a discussão de Luís Roberto Cardoso de Oliveira ${ }^{214}$, Maga Patalógica afirma sentir-se ofendida com o tratamento dispensado a ela quando pessoas não próximas têm acesso a informações íntimas sobre a trajetória de vida anterior à cirurgia, usando-as para ferir sua dignidade como sujeita humana, como mulher. Assim, pode-se afirmar que a experiência com o passado, nessas situações, é vivida pela interlocutora como negação da sua identidade.

Ofende-me quando alguém que não faz parte do meu círculo de amizades sabe sobre meu passado e utiliza essa informação contra mim. Ofende tanto a ponto de talvez eu ficar uma semana em depressão. Porque já vivenciei casos assim, aqui nas Clínicas, mesmo depois de ter os nomes alterados. Deu um erro no computador e acabou surgindo meu nome masculino num momento indevido. Um rapaz homossexual, o que é o pior de tudo ${ }^{215}$, sabendo que eu estava operada, com o meu $R G$ na outra mão com o nome de Maga Patalógica, mesmo assim chamando por fulano [o prenome anterior]e olhando para minha cara, com aquele intuito, como quem diz: - "Eu vou confrontá-la!" Eu não sei qual o pensamento dele: se queria tirar um sarro ou fazer uma brincadeira. Mas para mim era como se fosse assim: - "Eu vou humilhá-la em praça pública, mesmo!" Então, magoa, machuca, fere e ofende! E ainda hoje quando aparecem aqueles familiares que moram em outro estado e que ainda não tiveram contato comigo e puxam uma história assim: - "Nossa! meu Deus, você cortou e jogou fora?!"Isso é horrível! Ou quando estou com uma amiga e ela vira e fala assim: - "Você tinha de ter sido cabelereira!" Eu acho que é o cúmulo do absurdo. E ela sabe que eu passei pela cirurgia, né? Porque já aconteceu isso também! Terem uma visão, que eu não sei se veio pela mídia ou se veio pelo grupo homossexual, eu não sei de onde veio essas visões e esse tipo de tratamento para com a gente, nos comparando aquelas pessoas [aos LGBTTT]. Eu não sei de onde que veio... Só que é muito ruim! É uma tentativa de nos colocar num gueto, nos segregar junto com aqueles grupos homossexuais.

\footnotetext{
${ }^{214}$ Como debatido no primeiro capítulo com as obras: "Existe violência sem agressão moral?" e "Honra, Dignidade e Reciprocidade", entre outras.

${ }^{215}$ Para ela o fato de o rapaz ser ou parecer homossexual daria a ele condições de empatia e sensibilidade pela possível experiência de dor e sofrimento suficientes para que ele não ferisse a sua dignidade. A expressão "o que é o pior de tudo" marca a expectativa frustrada da ausência de compreensão e do cuidado que ela não teve.
} 
Já com as pessoas próximas, não acredito que me vejam diferentemente. Eu tenho amigos que sabem [do passado]. Até mesmo pela minha personalidade, por me conhecer, né? Então, acho que não me veem de maneira diferente. E uma coisa que eu noto muito nas pessoas também é assim: - "A Maga fez cirurgia?!" Fica aquela comoção, né?- "Ohhhhhh" E depois que conversam ou convivem comigo, dizem: "Gente, mas é a Maga! Ela é comum! Não era nem para ter contado de cirurgia..."É tranquilo!

\section{Quando não é necessário contar sobre o passado.}

Como visto no capítulo introdutório, o Estado brasileiro resguarda os eventuais direitos de terceiros em detrimento da intimidade e da dignidade da sujeita - mulher de fato que faz a cirurgia de adequação da genitália - quando determina que fique averbado no registro civil ter havido modificação judicial em relação ao prenome, justificada às vezes como "transexualismo" ou "transexualidade".A cena abaixo emergiu das lembranças de Maga numa situação em que a sujeita havia se casado com um homem sem que ele soubesse da trajetória anterior à cirurgia. A psicóloga é chamada a oferecer parecer sobre o caso, mostrando que a moça agiu para enganar o esposo. Trazendo igualmente trechos do capítulo inicial, a grande maioria dos agentes estatais e do público em geral, tende a culpabilizar ${ }^{216}$ as sujeitas pela omissão na história de vida. Assim, haver nascido com pênis (que não se escolhe, se nasce!) e ser mulher (cujas possibilidades de escolha são maiores!), desejando a cirurgia para começar vida nova, são quase sempre vistos como sinais de "enganação" vinda de uma pessoa "falsária" ou "não-autêntica", como se as sujeitas deliberadamente quisessem enganar as pessoas que amam. O desfecho do caso rememorado, segundo Maga, foi o indeferimento do pedido do marido, pois o julgador se convenceu de que na verdade ele desejava apenas deixá-la sem os bens construídos na relação de casal.

Eu já discuti isso com a minha psicóloga! Numa determinada época, eu cheguei e estava um caso em cima da mesa dela para ser julgado aqui em são Paulo. Era de

\footnotetext{
${ }^{216} \mathrm{O}$ "erro essencial sobre a pessoa", se comprovado, tem o poder de declarar a inexistência do casamento por culpa do cônjuge enganador. Tal declaração penaliza o suposto enganador com a impossibilidade do direito à divisão do patrimônio advindo com a relação. Em outras palavras, ela ou ele embora tenha contribuído para a construção do patrimônio comum, sai do casamento sem nada.
} 
um marido de uma garota que também era adequada cirurgicamente. Ele descobriu tempos depois e queria o divórcio, por isso a estava processando. O juiz chamou a chefe da Psicologia do HCSP para fazer um parecer sobre isso. E a psicóloga me disse: - "Poxa Maga, olha aqui! A menina com 18 anos de casada com esse homem... E só agora ele veio descobrir isso. Ele está se sentido enganado. No meu raciocínio, ela tinha que ter contado para ele." E aí nós brigamos!

\begin{abstract}
Eu falei: - "Eu acho que ela não tinha de ter contado nada! E a senhora como psicóloga que estudou por 40 anos a questão da transexualidade deveria dar um parecer favorável a ela dizendo que ela é uma mulher comum, como qualquer outra. Ela não pode ser processada simplesmente por ser adequada. Se ele precisava de uma vagina para se casar e entendeu que ela era mulher, ela deu isso para ele! Se ele precisava que ela fosse mulher na vida social, ela foi! E o passado dela não o ofende em nada!!!"

E ela: - "Não! Eu não posso fazer isso...."

E eu respondi: - "Então, minha senhora, você está tomando a posição dele e deixando ela de lado. Se a questão era ter filhos, ele não podia tê-los também. Está reclamando do quê? O que ele afinal de contas queria dela que ela não deu a ele??"
\end{abstract}

Ela tentou ainda falar algumas coisas, mas entendeu o que eu estava dizendo, tanto que eu acho que o processo não deu em nada. Ele na verdade queria tirar um apartamento dela, o carro, os bens. Tudo que eles construíram juntos, ele queria retirar dela! Ele tinha um carro e parece que uma empresa também. E a empresa era dos dois. Mas a questão toda eram os bens do casal que ele queria só para ele.

\title{
Criticas a política de representação dos grupos LGBTTT (ser eternamente “trans").
}

Assim, como as demais interlocutoras deste trabalho, Maga Patalógica é crítica à sua errada inclusão como membra das comunidades, grupos ou movimentos LGBTTT. Para ela, as "pessoas trans", as "transexuais" e as "mulheres transexuais", talvez estejam abarcadas nas especificidades LGBTTTs, pois se creem não serem mulheres. Contrariamente, as mulheres como ela não estão representadas ou inseridas num contexto LGBTTT, mas tão e somente de mulheres. Foi o que ela aprendeu nos tempos de militância. 
Eu imagino que o que mais doa neles [os LGBTTTs] é que as mulheres como eu querem e procuram o anonimato. Já eles e elas querem essa visibilidade "trans". A maior parte daquelas pessoas diz assim: - "Eu não vou fazer uma vagina eu vou fazer uma 'neovagina!' É como se elas jamais fossem ser mulheres na sua completude, mas eternamente "trans". Eternamente em desvantagens na vida em razão do corpo. Eu me lembro de uma reunião que tivemos num hotel para um evento de visibilidade "trans" em Vitória/ES. E aí estava todo mundo falando:- "A gente precisa de cotas para travestis e transexuais em diversos lugares e blá, blál'E disseram um monte de coisas para embasar isso [as cotas]. Todo mundo estava concordando. E eu falei: - "Gente, porra, cotas?!?Sei lá...Não concordo com isso, não! Não é por aí!" E a servidora do Ministério da Saúde que mediava os debates, me perguntou: - "Maga, por que não é por aí? Tente nos dar argumentos contrários." E eu argumentei: - "Porque eu entendo que eu sou uma mulher. Quem não me vê como mulher são os outros. E a partir do momento que eu tiver meu $R G$ e que eu for operada não me interessa o pensamento do outro!" Uma militante travesti, mas que se autointitula "trans", disse: - “Gente, mas nos somos massacradas! Nós somos humilhadas!" E não sei o que mais...- "Quando a pessoa nos humilha, nos humilha porque sabe que somos trans!" Eu compreendi o ponto de vista dela e falei: - "Mas se existe uma lei, como no caso da Maria da Penha, e ela é para mulheres, é só fazer um adendo. Como tem lá questões de raça para as mulheres negras ou etnia ${ }^{217}$ para outros grupos de mulheres, é só coloca ali "mulheres trans" que a hora que você chegar à delegacia da mulher e a pessoa olhar para você com desconfiança, você fala: -"Estou com a lei aqui e ela me protege!” Então, você não precisa de cotas para as "trans", né? Que nem a questão da verba para as cirurgias de transgenitalização. Existe uma verba na ginecologia e na urologia que realiza correções vaginais. Se realiza correção vaginal, pode também fazer as adequações. Então, a verba vem para mulheres, não vai para mulheres "transexuais". E o problema do nome é só respeitar a pessoa como deve se fazer com todo mundo. Não precisa de cotas para essas questões! E foi isso que tentei explicar na época. Aí, a mediadora falou: - "Realmente, Maga!" E continuei: - "Não temos que ir para o

\footnotetext{
${ }^{217}$ Diz o artigo2 ${ }^{0}$ da Lei 11.340/2006 (popularmente conhecida como Lei Maria da Penha): "Toda mulher, independentemente de classe, raça, etnia, orientação sexual, renda, cultura, nível educacional, idade e religião, goza dos direitos fundamentais inerentes à pessoa humana, sendo-lhe asseguradas as oportunidades e facilidades para viver sem violência, preservar sua saúde física e mental e seu aperfeiçoamento moral, intelectual e social."
} 
movimento de 'transexuais"! Temos que ir para o movimento de mulheres!" - "A gente não tem que pedir um ginecologista para 'transexual'. Tem que utilizar 0 ginecologista que já tem na rede de saúde!" - "A gente não tem que se intitular 'sou mulher trans'. Temos que ser quem nós somos!"

\section{Ousadia e preconceito.}

- "Ousadia tamanha que até os Orixás do Candomblé têm de obedecer à vontade dela!" - É assim que os Pais de Santo falam por aí de mim (gargalhadas). Imagine! Eu no Candomblé, no meio do machismo. Com essa "sopa de letrinhas" todinha lá: gays, lésbicas, travestis, etc... E todo mundo olhando para mim e apontando: "Aquela dali é louca, coitada! Ela pensa que ela é mulher..."- Graças a Deus eu sou muito respeitada no Candomblé. Eu tenho cadeira cativa! Então, eu me sento lá no meio dos grandes e eles têm de me engolir (risos). E com os Deuses também. $O$ Orixá tá lá dançando, fazendo toda a evolução dele, parando e cumprimentando. Toca numa barriga que tem um nenezinho lá dentro e diz: - "Esse terá um problema! Precisa fazer isso e isso para ter uma boa hora de parto." - Agora, cantemos para os Orixás irem embora (canta um ponto de despedida do Santo: "Paraxa Odé ôôô..."). E esse Orixá - Odé218 - guerreiro, caçador, Rei de uma cidade na África e de toda a religião do Candomblé no Brasil, muito preconceituoso - mandava matar mulheres porque não gostava delas - vira-se e passa por todo mundo. Não cumprimenta ninguém. Quando me vê se curva, coloca a cabeça no chão, em sinal de total submissão a mim. Levanta-se, tira um colar do pescoço e me dá de presente. Abraça-me, quando solta do abraço, coloca a mão em seu peito como quem diz: "Eu te amo!" Levanta-se e vai embora. (pausa) Quer mais aceitação que isso? Deixe quem quiser falar...

\footnotetext{
${ }^{218}$ De acordo com o "Dicionário Informal" virtual, Odé é o "Deus da caça" e "o grande patrono do candomblé", também sincretizado com Oxóssi.

Ver em: http://www.dicionarioinformal.com.br/significado/od\%C3\%A9/2515/

último acesso em: 15/05/15.
} 


\section{A sentença.}

A minha sentença [de alteração de nome e gênero] foi muito linda. Na realidade o juiz usou as palavras do laudo. A psicóloga colocou em algum momento do meu laudo algo mais ou menos assim: - "A paciente precisa de alteração de prenome e a mudança do gênero nos documentos para dignificar sua figura humana". E também por eu ter filhos. Isso estava no laudo e o juiz usou como sentença: - "Baseado no artigo, $x$, não sei o que, da Constituição, dou favorável as alterações pretendidas, pois depois da cirurgia entende-se que o corpo mudou, a pessoa mudou". Eu gostei muito do que eu li! Não tenho nada contra! Tinha no laudo uma parte da psicologia e outra do cirurgião da urologia dizendo que a cirurgia foi realizada com sucesso "é funcional e estética". E tem um laudo do ginecologista do HCSP com um trecho que diz assim: - "Qualquer profissional da saúde - abre aspas, 'ginecologista', fecha aspas - não saberá dizer se é uma vagina 'transexual' ou uma vagina nascida". E aí o juiz também usou isso. Então acho que por isso que eu não tive que colocar fotos[da vulva e vagina] ${ }^{219}$. Só certidões de cartório mesmo dizendo que não tive nenhum problema com o nome, com CPF, com a justiça. Na certidão de nascimento não ficou nada! Como que nascida biologicamente, ponto! Aonde vai a alteração é no livro. Eu tenho medo do casamento por isso ${ }^{220} \mathrm{Eu}$ sempre quis casar na igreja porque é aquele sonho, né? Do vestido branco, véu, grinalda... Não tem nada a ver com a minha religião, mas é um sonho meu! E também para dar um tapa de luva de pelica na cara da família. Porque você sabe, eu nunca fui prostituta ou profissional do sexo, mas a família sempre te imagina atrelada a essa profissão e também à marginalidade. Não digo pai e mãe, pois sempre foram meus parceiros. Porém, com o resto da família sempre rolou boatos: - "Ela é puta! Ela é traficante! Ela é drogada!" Tem esses estigmas aí contidos...

\footnotetext{
${ }^{219}$ No trabalho de Flávia Teixeira há um capítulo no qual mostra os absurdos cometidos pelo Poder Judiciário e o Ministério Público nos "laudos de perícia" na exposição indevida da intimidade das sujeitas e dos sujeitos demandantes das cirurgias com o uso de fotografias invasivas das genitálias na busca pelo "transexual autêntico".

${ }^{220}$ Nesse trecho, explicamos a ela que não precisa temer, pois o padre ou oficiante da cerimônia nupcial não terá acesso aos dados cartorários. A interlocutora suspira aliviada e diz sorrindo: - "Então, vou marcar o casamento!!"
} 


\section{Relacionamentos afetivos.}

Estou namorando... (diz com tom de afeto). Desde a época da minha cirurgia até hoje - estou completando quatro anos de cirurgia -só tive dois parceiros: meu antigo namorado e agora o atual que já está... Como é que eu explico isso? A gente se conhece há nove anos. E há nove anos, enquanto eu estava namorando outro, a gente não tinha nada. Quando eu me separava ele ia e me pegava (risos). Ele sempre me pediu em namoro no passado e eu nunca quis namorá-lo. Tanto é que ele tem uma filha de quatro anos que ele colocou o nome de "Maga" em minha homenagem. Ele fala que ele queria ter tido uma filha comigo! Na época, ele era casado e botou o nome de Maga. A ex-mulher dele me odeia por isso (risos). Porque ela sabe que é por minha causa. Agora, a gente começou a namorar e estou bem! Estamos namorando!

Tive um relacionamento com um designer de sapatos. É um cara que não aparenta ser daquele "meio"[se refere aos gays]. É até nojento falar "maricona" 221 "(risos), mas é assim que eles se referem, né? São coisas que você faz uma reflexão hoje e fala assim: - "Meu!?Não fazia parte da minha vida!" E foi uma coisa estúpida para cacete! Não por eu ter o corpo que eu tenho hoje, porque eu poderia perfeitamente ser lésbica ou comprar uma calcinha com pênis acoplado e fazer a satisfação do outro. Aliás, hoje de tão segura que estou não seria nenhum tabu. Com meu antigo corpo seria um problema. Só para você compreender do que estou falando, aquilo [ser sexualmente ativa utilizando o pênis para penetrar o parceiro] não me completava. Não fazia parte de mim como mulher. E como mulher, eu o expulsava. Hoje, entendo que o que expulsava fulano da minha vida era isso. Eu ouvia uma amiga falar: "Nossa! Mas esse cara é um amante de travestis, é um T-lover?"22" E aí ele gostava de travestis de filmes pornôs que tinham pintos enormes. Então, essas coisas...Eu olhava e falava: - "Onde em sã consciência eu fiquei com esse homem?!?" Não

\footnotetext{
${ }^{221}$ Don Kulick (2008) explica que as travestis se referem a seus clientes de programas sexuais por esse termo.

${ }^{222}$ Num blog sobre diversidade sexual encontramos uma definição de TLovers: "é a pessoa que admira Travestis e Transexuais. Um homem que ama, sente tesão e atração por Travestis e Trans. Eu sou a prova disto, pois eu gosto muito de Travestis. Sou louco por elas e não conseguiria ser um homem completo sem exercer essa orientação". Ver em: http://blogsdagazetaweb.com.br/diversidade/t-lovers-os-admiradores-de-travestis-crossdressers-etransexuais/ Último acesso em: 15/05/15.
} 
havia a menor condição! Mas eu precisava viver a situação para ter a certeza de que não era a minha vida.

\section{Filhos e maternidade.}

Como dito acima, Maga nos pediu que não falasse muito sobre as crianças. Por isso, apesar de ser assunto muito importante na vida da interlocutora, sobre seus filhos, abordaremos somente o necessário. Ela é mãe de um menino e uma menina na faixa etária entre sete a doze anos. A mãe biológica deixou as crianças em posse da Maga tão logo nasceram.

Eu sempre quis ser mãe! Era uma coisa muito forte. Graças a Deus que aconteceu naturalmente. Eu não provoquei, aconteceu. Mas se não tivesse realizado esse sonho, eu também não estaria frustrada. Meus filhos são adotivos, só que ainda não estão com o meu nome da certidão de nascimento. Eu estava esperando todo esse processo de mudança de nome para dar entrada nos documentos. Pensei: - Não vou fazer uma certidão [com o nome anterior, masculino], porque meus filhos já leem e poderão ter acesso. Então, eu continuo mantendo o nome da mãe biológica lá223. Ainda bem que eu tive essa sacada de não mexer nos documentos dos meus filhos antes de mudar meu nome, pois eu nunca conseguiria colocar "mãe" nas certidões tendo meu antigo nome. Por isso que eu não mexi na questão de mudar o registro dos meus filhos, entende? A única coisa que muito me preocupa é em relação aos meus filhos. Para que eles não sejam expostos.

\section{Vida profissional.}

Antes de cuidar da avó doente e já falecida, Maga trabalhava como auxiliar de escritório, espécie de secretária. Em razão da gentileza no trato com as pessoas e do senso de responsabilidade venceu o preconceito e foi contratada. Atualmente, o Candomblé além de ser a fé religiosa é igualmente atividade laboral

\footnotetext{
${ }^{223}$ Interessante lembrar que as certidões de nascimento confeccionadas na atualidade, por força da normativa do Conselho Nacional de Justiça (CNJ), não contêm mais a expressão "filho/a de.... e da ....", mas apenas "filiação" para que no campo próprio contenham os nomes dos/das genitoras/res e não mais "mãe" e "pai".
} 
da qual retira seus rendimentos. Ela afirma que as atividades do Candomblé são muito extensas e quotidianas, não permitindo que mantenha um emprego formal ou atividade laboral em paralelo.

Engraçado que comecei a trabalhar por indicação e a minha patroa à época não queria me contratar porque eu era negra e tinha o lance da transexualidade. Ela achava que eu era marginal... Daí, ela precisou e me contratou apenas por um dia como experiência. Adorou meu trabalho e se simpatizou comigo. Trabalhei com ela por cinco anos. Eu cuidava da agenda pessoal e fazia pagamentos, além das atividades e rotinas de escritório. Foi um dos meus melhores empregos!

E hoje eu vivo do Orixá. Eu costumo dizer que vivo da caridade das pessoas, porque eu nunca fui tirana em cobrar "milhões" das pessoas. Tudo meu é superbaratinho! Acho que por isso que muita gente me procura para cuidar do santo, fazer suas limpezas e seus trabalhos para os vários fins. E tudo é mediante o Oráculo do Orixá ${ }^{224}$. Às vezes, tenho quatro pessoas para atender ou quatro, cinco, trabalhos para fazer e aí eu sou impedida de manter outras atividades. Porque, primeiro: o cansaço físico é muito grande; segundo, eu tenho a questão dor no quadril; terceiro às vezes os trabalhos são longos, não tem como pará-los para atender outra pessoa e tem que remarcar.

\section{O chamado dos Deuses (A Mãe dos Nove Céus).}

Eu recebi o chamado dos Deuses ainda criança. Venho de uma família do Candomblé que tem passado hierarquicamente através das mulheres da minha família. Começou com a minha bisavó, depois foi para minha avó, para minha mãe e agora veio para mim. Quando eu era pequena, com cerca de oito anos, sonhava com uma mulher que vinha em aparência se tornando uma grande onda. Como se eu estivesse na praia e uma mulher saindo de dentro da onda. Ela me pedia para eu ir com ela. Eu passava dias com medo dessa mulher. E ai eu tinha que ir ao terreiro

\footnotetext{
${ }^{224}$ No Candomblé o Oráculo mais utilizado é o jogo de búzios, também chamado do "Ifá". Maga Patalógica esclarece: "Os jogos são realizados mediante a procura, tanto para os filhos, como para os clientes ou pessoas que fazem parte da comunidade. Abro os jogos e as respostas são ditas mediante o que o Orixá determina, nunca sou eu".
} 
de Candomblé junto com aminha avó, numa Casa onde ela se tratava. E lá eu tomava banhos, faziam limpezas no meu corpo, e sempre falavam: - "O caminho dela é o Orixá. O Orixá a está chamando. O Orixá a quer!" Assim, acabei entrando no Candomblé. A minha última crise [espiritual]acho que eu tinha nove anos. Foi uma crise muito grande que desencadeou uma bronquite muito forte, eu também sofria de bronquite. Fui internada por quase 10 dias sem poder respirar, com falta de ar e com o pulmão chiando, ameaçando parar. Eu tratei no Orixá, depois tratei no médico. Quando sai do hospital, minha avó preparou as coisas para que eu fosse iniciada no Candomblé. Nesse meio tempo, o Orixá da minha avó que era lemanjá, incorporou e disse: - "Escolheram uma pessoa da família que será a herdeira do Axé!" Não falaram que era eu. Foram para o Jogo de Búzios, viram aqui, viram ali e falaram:- "Vamos oferecer a Maga Patalógica!" E ai lemanjá falou: "É essa mesmo que eu quero! Não quero mais nenhuma outra! Mais ninguém da família seguirá a religião!" Apenas eu segui. Sou de lansã. Costuma-se dizer "lansã de Balé", né? Ela veste branco e está ligada ao Culto aos Mortos. Quando a gente morre, a alma tem que ir para um determinado lugar e é ela quem faz essa passagem: da saída do corpo até o Orum, porque Orum seria o céu. Um dos nomes dela, que seria um título, é: "Oya messan Orum" ("a Mãe dos Nove Céus").Para nós existem nove espaços sobrenaturais para onde as pessoas vão, de acordo com a sua realidade, depois da morte. E a minha Oya é quem faz esse traslado da alma.

\section{Matriarca.}

Estou num lugar de matriarca da minha família de pai, mãe, tios e tias. Minha mãe faleceu e minha avó também. Eu me tornei a matriarca. Não sei se também pela religião porque todo mundo me vê assim, muito mãezona. No Santo, eu estou em torno de 90 filhos meus. Mas tem muitas iniciações que não se dão assim. Se dão com outra pessoa, onde eu sou a segunda pessoa, no caso. Existe a primeira que seria a Mãe de Santo da pessoa e vem uma segunda. Eu sou a segunda de mais umas 200 filhas e filhos. Porque quando vai iniciar o Orixá precisa-se dividir o Axé. E as pessoas, por gostarem da maneira como eu conduzo o Orixá, me chamam. Então, assim, tem bastante gente aí. Completo agora em maio, 25 anos de iniciada. Só que como te disse, eu nasci no Candomblé. Vem da família, vem da minha bisavó, da minha avó, da minha mãe. É ancestral! E os meus filhos também. Somos todos iniciados no Candomblé. 


\section{A vida de Santo por obrigação.}

Eu acredito assim: entrei no Orixá obrigada! Nunca foi algo que eu pudesse optar. Algumas vezes, devido ao meu grande desejo de trabalhar, estudar; de constituir família com marido e filhos, eu me ausentei da religião. Mas o Orixá ia lá e mudava tudo! Levava-me urgentemente para o barracão para cuidar de alguém que estava doente ou para algum Candomblé muito importante. Lembro-me de que quando vovó ficou doente, eu trabalhava em dois empregos. Eu era muito feliz! Depois de ter arrumado a casa, construído e mobiliado para deixar as coisas bem confortáveis para minha família, eu pensava em entrar numa faculdade. Ede repente "bum", a vovó fica doente. Tive que largar tudo e cuidar dela. Ela teve um derrame voltou a ser criança, entende? A única pessoa que ela reconhecia era eu. Cuidei dela por oito meses até se restabelecer. Levou praticamente um ano e meio para ela ficar bem e eu continuar a minha vida, sair de casa para trabalhar novamente. Ela ficou internada, também. Nessa época eu namorava e estava muito feliz com meu namorado. A gente se dava muito bem, se completava, porém eu não conseguia ter uma vida com ele por causa da internação de vovó. Quando ela chegou em casa, tive que ir para o barracão. Deixei minhas primas cuidando dela para fazer um trabalho para Obaluaê ${ }^{225}$, para ver se ela melhorava. E ele [o namorado] me disse que se eu não fosse ao motel com ele a gente terminaria ali. Só que eu não podia. Eu não podia nem fazer sexo. Eu tinha que estar com o corpo puro, com o corpo limpo ${ }^{226}$. E eu falei: - "Não! A vida de vovó em primeiro lugar!" $E$ assim, terminamos. Perdemos até a amizade. Hoje nem amigos somos.

\section{O trabalho de uma Mãe de Santo.}

É muita coisa! Difícil explicar... A partir do momento que eu me tornei Sacerdotisa, que eu me tornei Yalorixá, ficou-me incumbido cuidar dos Orixás do Candomblé. Cuidar com certos segredos que as outras pessoas não têm e com uma dedicação

\footnotetext{
${ }^{225}$ De acordo com sítios da internet, Obaluaê ou Omulu é o Orixá da cura, da medicina e da transformação. Ver em: http://pt.wikipedia.org/wiki/Obaluae na Umbanda Último acesso em: 15/05/15.

${ }^{226}$ A Interlocutora contou-me que para determinados rituais ou trabalhos mágicos no Candomblé é necessário que a Sacerdotisa ou o Sacerdote no dia do rito não ingira alimentos que o santo não goste, nem bebidas alcoólicas. Também está proibida a prática de sexo.
} 
que as outras pessoas não dão. São estudos e mais estudos. Conhecer a palavra do Orixá, a fonética. Aprender como ele gosta de ser tratado. Como ele gosta de ser cultuado. Porque cada Orixá tem um culto diferente. Para um, você sacrifica o animal de um jeito; para outro, de outra maneira. Para um, é um animal de uma cor; para outro é um animal de outra. Cada animal tem um significado dentro do sacrifício, tem um porquê de se sacrificar. Tem também as pinturas que são feitas no corpo da pessoa. As penas que são carregadas na cabeça. As cantigas que envolvem. São mil segredos que somente as Yalorixás (as Mães de Santo),detêm. As pessoas trazem os seus santos para cuidarem. Automaticamente esses santos acabam ficando em minha casa. Ficando em minha casa eu tenho de zelar por eles, pela energia deles. Então, de segunda a segunda: acordar cedo; colocar vela; trocar a água; fazer determinada reza. Aí, no mês "x" faz essa reza, no mês " $y$ " faz aquela reza. Na época de outubro, batem-se chifres. Na época de julho, rodam um chocalho que imita o barulho do trovão. E assim consecutivamente. Eu sempre digo que mãe de santo tem que ser completa! Ela tem que aprender a tocar e cantar. Mas as mulheres não tocam atabaque. Porém, eu tenho que saber tocar, para poder ensinar a um filho ou para dizer a determinada pessoa que esteja tocando, que ela está tocando errado.

Nas atividades de uma Mãe de Santo tem as obrigações do Candomblé. Elas são obrigatórias e uma das coisas que eu mais faço, que as pessoas mais me procuram. Então, você inicia o Orixá: raspa a cabeça; corta seu corpo; sacrificam-se animais. Tem toda uma festa ritualística que envolve comidas, roupas e danças. Quando você completa um ano, tem que renovar tudo aquilo dali, fazer novamente. Essas atividades duram em torno de 20 dias. Depois, você faz a obrigação de três anos. Com cinco anos, renova novamente. Aí, você fecha esse primeiro ciclo que é com sete anos, né? Algumas pessoas entendem que é quando você se forma e pega os seus direitos: tornar-se Pai ou Mãe de Santo. Todo ano se renova aquela energia, como se estivesse comemorando um aniversário. Tanto que as obrigações são chamadas de "ajôdu" que significa "aniversário de santo". Você comemora: oito, nove, dez, onze, doze. Todo ano você faz uma oferenda que é mais singela depois dos sete anos. E aí vêm os 14 anos onde se arria novamente uma oferenda grande aos Orixás. Depois de sete vem a de 21 e, assim, a cada sete anos você faz; ou a cada data que você entende que é importante ou que está financeiramente 
preparada, as suas obrigações. Eu vou fazer a minha agora de 25 anos! Vou comemorar as bodas de prata que é uma cerimônia muito importante dentro do Candomblé e será importante para mim também!

\section{Histórias no Candomblé.}

Como visto acima, o reconhecimento de Maga Patalógica não se dá apenas entre os seres humanos. Os espíritos e Orixás, mais até do que as humanas, a reconhecem como mulher. Nessas duas passagens, Maga nos mostra algumas facetas desse reconhecimento.

Deixa eu te contar umas histórias que eu passei no Candomblé que têm a ver com essa questão da sexualidade e da compreensão do Orixá sobre mim. Fui convidada a participar de uma festa de Ogum, chamada de "feijoada de Ogum". Eu tinha 20 anos de idade na época e tinha um cargo no Candomblé, chamado "Yákekerê", Mãe Pequena, um cargo que me foi dado por um Orixá muito velho dentro da religião ${ }^{227}$. E quando eu cheguei lá, foram chamadas apenas as mulheres de cargo para poder dançar. E aí um grupo de gays queria que eu não dançasse porque eu sofria dessa suposta transexualidade. Eu naquela época não tinha preguiça: enfrentava mesmo as pessoas! E acabei enfrentando esse grupo de gays e fui dançar mesmo contra a vontade deles. Daí, os Oguns começaram a incorporar. E eles foram incorporando, incorporando. E incorporou o Ogum do dono da festa, do dono dessa Casa, o Ogum de um homem heterossexual. E Ogum é um Orixá muito preconceituoso, um Orixá masculino, arredio. E Ogum virou. Quando terminou de virar já veio, já botou a cabeça nos meus pés. Abraçou-me. Convidou-me para trocar a roupa dele, para ajudar a colocar os adornos dele. Então, assim, se eu sou aceita por Ogum, né? Quem são as pessoas para me julgar?

E na segunda história, fui convidada a participar de um ritual de Axexê, um ritual fúnebre. Algumas pessoas não queriam que eu fosse vestida a caráter. Queriam que eu usasse uma túnica masculina. E eu falei: - "Se tiver que participar assim, eu nem

\footnotetext{
${ }^{227}$ Interessante aqui rememorar o trabalho de Rita Segato descrito no começo desse capítulo. Se Maga fosse vista pela família ou a coletividade como homem ou "trans" ela não poderia ter o cargo de Mãe Pequena antes da cirurgia, pois sua essência - simbolizada pelo pênis - seria vista e reconhecida obrigatoriamente como masculina. Naquela etnografia, Segato descola a genitália ou sexo da personalidade, mas não do cargo. Ela poderia ser aceita como "filho" ou "pai" de santo, porém nunca como "filha" "Mãe Pequena" ou, mais recentemente, Mãe de Santo.
} 
vou. Que isso? Que loucura!". E aí, a chefe desse culto, uma Yalorixá muito famosa do Brasil que detém um Axé muito grande, disse-me: - "Não, não! Não trouxe sua roupa? Vamos abrir meu carro, lá tem baianas(saias rodadas usadas pelas mulheres no Candomblé). Eu conheci você mulher. Você nasceu mulher e para mim você é mulher! Escolha uma para você! Não tem que ninguém vir falar nada, não. Vamos esperar Oyá chegar, que Oyá levará todos os carregos de Egun ${ }^{228}$. Vou botar você de Oyá. Tem Oyá mais velha aqui, mas eu vou usar a sua. E está tudo certo. Não liga para as pessoas!"

\section{Perspectivas para as mulheres como a interlocutora.}

Quanto ao futuro para as mulheres de fato, Maga Patalógica assim com as demais interlocutoras deseja uma compreensão real e prematura da situação das sujeitas para se evitar sofrimentos e a perda do tempo. Ela critica o que considera o caráter "transgressor ${ }^{229 ", ~ d o ~ q u e ~ s e ~ n o m e i a ~ p o r ~ " t r a n s e x u a l i d a d e " . ~}$

Seria melhor uma descoberta de si mais cedo, né? E a cara e a coragem que eu tinha no passado! Hoje, eu acredito que as pessoas estão se espelhando muito no caráter "transgressor". É bonito hoje ter a coragem de bater no peito e falar: - "Sou transexual, meu amor!" Antigamente você sabia que se falasse isso, eles te colocariam para fora de um restaurante, de um ambiente qualquer, na hora. Hoje, é uma questão de status financeiro. A transexual hoje é a garota rica que foi e fez cirurgia. Se ela fez cirurgia tem dinheiro para gastar. Então, os hotéis, os restaurantes querem sua presença. E a mocidade está vindo atrás disso! Você vê os grupos nas redes sociais, as discussões na internet: - "Amiga, onde você colocou seu peito? Quanto custa? Amiga, estou tomando tal hormônio e quero tomar outro. Estou sentindo que meu peito está murchando." E elas têm orgulho de postar essas perguntas nas redes sociais. Elas não têm uma vida feminina, têm uma vida transexual. Eu fico pensando assim: - "Tudo bem!" Tem que ter uma lei que resguarde essa pessoa na escola, na rua. Dê uma segurança a ela. Só que essa

\footnotetext{
${ }^{228}$ Espírito de pessoas já falecidas que vagueiam no mundo e são controlados por Yansã ou Oya.

229 Interessante comparar a crítica da interlocutora com as expectativas das pesquisadoras e acadêmicas "revolucionárias de gênero". Se a primeira não se vê refletida na suposta "transgressão" que a "transexualidade" evocaria; as expectativas das últimas se tornam ainda mais distantes das realidades das sujeitas de carne e osso.
} 
figura não compreendeu que tem uma imagem: ela é mulher. Então, se existe um banheiro feminino, é para ela. Com ou sem cirurgia, o que vai impedi-la de continuar lá é a postura dentro do banheiro. Porque se ela quiser sair de dentro do banheiro mostrando a genitália para todo mundo, as pessoas vão entender e ali estará uma prova, ao menos aos olhos da sociedade, de que ela não é uma mulher. Ninguém mostra a vagina para outra, não é verdade? O que me preocupa da mocidade de hoje é isso: elas estão criando o terceiro gênero. E se cogita hoje, o que algumas pessoas na militância querem, é que nos registros civis esteja um espaço contendo lá: "heterossexual", "homossexual" ou "transexual". E eu já disse, não precisa disso! Eu não quero chegar num lugar e ter que passar pela catraca "x", de "transexual". Eu quero a catraca igual à de todo mundo. Lá no passado, o projeto Tulipa ${ }^{230}$ veio trazer inserção, dizem. Que inserção foi essa? Levar meia dúzia de pessoas para falar assim: - "Eu não sou homem, nem mulher, eu estou no meio". É legal você não se definir. Mas daí você querer isso para o outro?!? Eu estou definida, eu sei quem sou eu! E todo mundo tem de me respeitar. Mas não tem esse respeito, não! Eles falam: - "Aquelas ali estão loucas! Elas estão vivendo num conto de fadas, no mundo da Carochinha. Um dia elas vão acordar!" Aliás, o nome que a gente tem nem é de 'Malévola', é de 'Alice'! É que elas[as travestis e transexuais] nos chamam de Alice $^{231}$. Eu nunca quis aquela carteirinha do SUS para transexuais ${ }^{232}$. Eu nunca quis! Minha médica cansou de falar: - "Maga, tem uma tal de carteirinha para

\footnotetext{
${ }^{230} \mathrm{~A}$ interlocutora me explicou que nas militâncias LGBTTT, o "Projeto Tulipa" eram cursos de capacitação em DST/HIV/Aids para instrumentalizar e possibilitar o protagonismo de travestis, transexuais e transgêneros na luta contra o preconceito e a Aids, nas décadas de 1990/2010. Também consistiam em espaços de diálogos com representantes da sociedade civil e gestores para implantação de projetos de inserção social para aquelas comunidades. De acordo com a interlocutora frequentemente os cursos se tornavam espaços de disputas de poder entre as identidades travestis e transexuais, levando, inclusive, a animosidades. Ver em: http://www.aids.gov.br/noticia/projeto-tulipacapacita-travestis-e-transgeneros

Último acesso em: 15/05/15.

${ }^{231}$ Com esse termo a interlocutora salienta que é vista pelos LGBTTT como "alienada", "iludida", "fora do mundo". Uma alusão ao conto de Lewis Carroll "Alice no País das Maravilhas", cuja protagonista é levada a outra dimensão de maneira fantástica, fantasiada, fora da normalidade.

${ }^{232}$ Refere-se ao uso do nome social como descrito no $3^{\circ}$ principio da Carta dos Direitos dos Usuários da Saúde. Ver em: http://bvsms.saude.gov.br/bvs/publicacoes/carta direito usuarios 2ed2007.pdf Último acesso em: 15/05/15.

Hoje é possível às travestis e "transexuais" reivindicarem o tratamento respeitoso pelo nome social na administração do Estado e em muitas escolas em todo o Brasil. Ver em:

http://www1.folha.uol.com.br/cotidiano/2015/03/1599598-estudantes-travestis-adotam-novo-nome-emescolas-estaduais-de-sp.shtml

Último acesso em: 15/05/15.
} 
'trans'..." Eu respondia que não queria aquilo. Aquilo é para "trans"! Não quero! "Ou eu mudo meu nome ou não quero isso!" - Eu dizia.

\section{Futuro}

Eu queria muita coisa! Queria muito fazer faculdade, mas não pude realizar. A religião hoje toma muito meu tempo. E eu não quero crescer mais na religião porque eu não vou ter vida pessoal. Hoje eu enfrento um problema de saúde na região do quadril que já tem durado muito. Esse ano inteira cinco anos que estou doente. E dói demais! Eu tenho irritabilidade por causa disso. Ano passado, o médico pediu-me que não tomasse remédio nenhum para dor. Esse ano, ele já me receitou codeína porque a dor é muito, muito grande. Então, agora eu só quero me curar! A cirurgia é muito delicada, ficarei um ano debilitada. Posso ficar um ano sem andar. Vou depender de cadeira de rodas, depender de outra pessoa... Estou muito apreensiva com isso. Minha perspectiva de futuro é terminar essa fase. Melhorar para poder voltar à minha vida normal. 
Capítulo 5 - Malévola.

"E a coisa mais ridícula é que tudo isso é por causa de um genital!! Por que um genital tem essa importância toda??"

Gente! Como as pessoas são incomodadas com o que as pessoas têm entre as pernas! Como isso faz a diferença na cabeça das pessoas... É uma desgraça! Uma mulher está andando na rua e alguém aponta e diz assim: - "Sabia que aquela dali tem um pinto?" Estragam a vida da pessoa toda! Cai tudo por terra! Ela vira assim, um monstro, um marginal, uma aberração porque tem um pinto ainda. Acaba com tudo! Todas as qualidades dela vão embora. E a primeira coisa que dizem é: - "Não! Não é mulher!" Por causa de uma porra de uma genitália!! E desgraçam a vida da pessoa sem sentir remorso, sem dó, nem pena. Dizem assim: - "Ah! Desculpa, porque ninguém vê... Gente mas isso é maravilho!! Olha como ela conseguiu... Ela é tãoooo (ênfase no "tão") feminina.... Mas tem um pênis! Ela é tão feminina, mas tem um pinto!"

Malévola é maquiladora e artista multilinguagens ${ }^{233}$ de 40 anos de idade. Mora em Brasília/DF com a mãe e os dois gatos numa confortável casa em uma das cidades satélites do Distrito Federal. Filha do meio de uma família de duas irmãs e dois irmãos, atualmente, estuda inglês e se dedica aos projetos artísticos dos quais retira seus rendimentos.

A intimidade permitiu-nos estabelecer formas experimentais de coletas de depoimentos e escrita. Nossas entrevistas pessoais foram realizadas em sua casa

\footnotetext{
${ }^{233}$ A interlocutora explica que nesses termos estão consideradas as habilidades artísticas: artes visuais, trabalhos manuais, artes cênicas, performances, desfiles, entre outras. Além das atividades de produção.
} 
em duas ocasiões: na primeira semana de agosto de 2014 e na primeira quinzena de janeiro de 2015. Pedimos a ela que também escrevesse pequenos textos de memórias, com cenas que considerasse marcantes da infância, adolescência e maturidade, nos permitindo apresentá-la com a riqueza de suas palavras. Mesclamos as duas formas de composição no capítulo para tentar apresentar cenas de uma trajetória de vida, mantendo o cuidado, novamente, com informações cuja exposição pudesse identificar a sujeita, afastando também alguma expectativa biográfica.

Nascida numa pequena cidade do estado do Maranhão/MA teve uma infância difícil, pois além dos preconceitos familiares e da vizinhança, estudou por muitos anos em uma instituição católica dirigida por padres. Na moral cristã, mulheres e homens têm papeis sociais pré-estabelecidos e rigidamente definidos a partir dos órgãos sexuais e reprodutivos de nascimento. "A mulher", tomada como sujeita única e universal ${ }^{234}$, tem como modelo primordial a abnegada Virgem Maria e suas variações ${ }^{235}$. Igualmente, "o homem" deve ser e portar-se como José, Jesus de Nazaré ou algum patriarca cristão. Assim, a identidade real da interlocutora foi horrivelmente subjugada e contida.

Eu me lembro de que tinha por volta de cinco ou seis anos quando eu disse: - "Mãe, eu sou mulher igual as minhas irmãs! Uma mulher comum como qualquer outra." - Eu colocava meu pintinho entre as minhas pernas e puxava bem os shorts para parecer que não havia nada ali. Minha mãe deixava-me livre para brincar de menina em casa. Eu inclusive tinha permissão para usar as roupas e sapatos dela, sem que meu pai soubesse. Porém ela temia que eu sofresse no futuro.

[...] Na escola era um pesadelo! Meus sonhos eram desfeitos em todos os lugares: na sala de aula, na chamada, com os colegas, no banheiro, no recreio... Quem eu queria ser tinha de ficar bem escondida, porque quando sabiam eu virava a chacota do colégio, uma aberração!

\footnotetext{
${ }^{234}$ Refiro-me aqui às críticas dos movimentos feministas, encabeçados principalmente pelos coletivos de mulheres negras, quanto ao que se pode chamar de "modelo universal" de mulher. Tal concepção universalista não leva em conta as multiplicidades das sujeitas contidas em mulheres.

${ }^{235}$ No sítio "Católicas net" há uma extensa e curiosa lista dos nomes atribuídos a "Virgem Maria". Dentre eles, estão: "Nossa Senhora das Angústias", "Nossa Senhora Aparecida", "Nossa Senhora da Conceição", "Consoladora", "Do Desterro", "Da Estrela", "Da Glória", "Madre de Deus", "Das Maravilhas" e outros. Ver em:

http://www.catolicanet.com.br/index.php?option=com content\&view=article\&id=572:lista-de-nomesde-nossa-senhora\&catid=66: maria\&ltemid $=137$

Último acesso em: 16/05/15.
} 
E a escola foi marcadamente um dos piores espaços para Malévola:

Eu procurava de alguma forma ficar invisível desde o meu primeiro dia de escola. Quando meu nome era chamado na lista de presença, eu sentia muita vergonha... Queria estar ali, mas com outro nome, sendo reconhecida nos meios femininos!

A saída para continuar vivendo foi ficar em silêncio, "invisível"236.

[...] Aperfeiçoei meus métodos de invisibilidade. Encontrei no silêncio uma forma poderosa de me defender dos ataques de familiares, vizinhos e colegas de escola.

No final da adolescência as necessidades sexuais afloraram. Mesmo tendo uma educação muito repressora, permitiu-se lançar em diversas aventuras, realizando muitas das fantasias com enorme prazer.

[...] Paramos numa escola que estava em obras. Lá ele tirou a roupa e nu, falou: - "Sou todo seu!" Comecei a acariciar o tórax peludo, fui tirando minha roupa e inteiramente nua, me esfreguei muito naqueles pelos.

[...] Fiz um sexo oral muito intenso nele! Sentir aqueles pelos arrepiados foi a melhor resposta de aprovação que eu poderia esperar. Era a primeira vez que eu fazia sexo ao ar livre, mas me sentia segura com ele. Foi intenso! Saí com os joelhos ralados, mas inteiramente feliz e satisfeita!

Atualmente, assim como Úrsula - a Feiticeira do Mar, Malévola experimenta o sabor amargo da espera pela cirurgia pelo Sistema Único de Saúde (SUS). Deseja que sua adequação genital seja feita no Hospital de Clínicas de Porto Alegre (HCPA), no estado do Rio Grande do Sul. No passado sofreu muito com a espera e o descaso. Foi necessário inclusive entrar com uma ação judicial para que o Estado cumpra a lei. Hoje, afirma que a angústia é "normal".

[...] Hoje estou tranquila! Estou fazendo todas as coisas que tenho que fazer. Não paro mais a minha vida para esperar a cirurgia. Porque é importante você ter uma vida. A cirurgia não vai solucionar todos os seus problemas! Antes, eu pensava um monte de besteiras... Não queria viver, era dolorido esperar, não havia a quem procurar. Era muito difícil até passar os dias... É ruim não ter ao menos uma consulta marcada, sabe? A minha preocupação era essa: colocar meu pezinho lá dentro [do HCPA]! Ter a garantia que estou lá, que sou vista e que existo dentro do sistema [SUS]. Eles

\footnotetext{
236 "Invisível" aqui, segundo a interlocutora, tem o sentido de não chamar a atenção para si. Passar sem ser vista ou notada. O mesmo que "passar batida".
} 
têm um protocolo com prazos para cumprir. Então, acho que é uma angustia normal.

Recentemente, iniciou as consultas mensais nos grupos terapêuticos do PROTIG, se deslocando mensalmente para Porto Alegre/RS para que nos próximos anos seja operada como prescrevem as normativas.

Conhecemo-nos há cerca de 20 anos em uma pequena companhia de teatro em Brasília/DF. Eu fazia um curso de teatro; ela atuava, produzia e montava figurinos, cenários, adereços, etc. A convivência se tornou amizade, carinho, afeto, amor. Hoje nos consideramos irmãs, nos apoiando mutuamente na nossa sororidade ${ }^{237}$.Não sabemos explicar racionalmente porque nos aproximamos tanto. Há muitos anos, um Pai de Santo numa leitura de búzios, nos disse: - "Vocês já se conhecem há muito tempo. De outras vidas até! Nasceram para cuidar uma da outra..." E desde então nunca mais nos desgrudamos.

Malévola ou Maléfica (em inglês "Maleficent") é uma personagem muito antiga no imaginário popular europeu dos séculos XVII e XIX. Reeditada nos contos dos alemães Jacob e Wilheml Grimm (os famosos Irmãos Grimm!) nos primeiros anos de 1800, ganhou formas acentuadas para se contrapor à imagem da mocinha, Bela Adormecida, no conto homônimo ${ }^{238}$. Nas narrativas dos Grimm, uma velha bruxa fora negligenciada pelo rei ao convite para tão aguardada festa do reino: o batismo da princesa. Vingativa, a fada má lança uma maldição: se a princesinha na fase adulta espetar o dedo num fuso de uma roca, adormecerá profundamente só podendo ser despertada por um beijo de amor verdadeiro. Mesmo com todos os esforços paternos, a menina curiosa espeta o dedo e além dela, todo o reino adormece. Cem anos depois, um destemido príncipe beija a princesa, acordando não apenas a amada, mas toda a corte. Em 1959, a Walt Disney produziu outra versão para o conto. Malévola é então a sombria bruxa malvada feita sob medida para caber nos moldes conservadores da época, num final apoteótico do bem exterminando o mal, encantando milhares de pessoas nos cinemas. Recentemente,

\footnotetext{
${ }^{237}$ Sororidade, do latim "soror", significa "irmã" ou "irmãs". Termo empregado para marcar relações de irmandade e carinho entre mulheres, mesmo não pertencendo a laços de sangue. Os movimentos feministas frequentemente utilizam esse termo ao invés de "fraternidade" (irmandade entre "fatras", irmãos).

${ }^{238}$ Ver em: http://pt.wikipedia.org/wiki/A Bela Adormecida \%28conto\%29 Último acesso em: 16/05/15.
} 
em 2014, o estúdio Walt Disney Picturere filmou a história, dessa vez sob o ponto de vista da antagonista no pretensioso "Maleficent" ${ }^{\text {"39 }} \mathrm{com}$ a atriz norte-americana Angelina Jolie como a bruxa do título. Nessa versão, a saga começa apresentando Malévola como uma fada protetora de um brejo mágico situado próximo a um reino de seres humanos. Ela conhece um rapaz e ambos se apaixonam, porém levado pela ambição em se tornar rei e em razão de uma demonstração de confiabilidade, o rapaz trai a fada tentando matá-la. Sem coragem de exterminá-la em definitivo, dáIhe um sonífero e arranca-lhe suas lindas asas negras para comprovar que fora morta por ele. Em profundo sofrimento, Malévola constrói um reino de trevas em seu redor e jura vingança. Mas, vencida pelo seu enorme coração, vê na menina enfeitiçada uma filha. Enternecida, consegue quebrar o próprio feitiço, salvando a moça e recuperando suas asas.

Essa última versão do conto dos Grimm é interessante para esse trabalho, pois raramente se vê no mundo do entretenimento, a preocupação em humanizar uma vilã, sobretudo uma bruxa perversa. A maldade agora é ao menos justificada por eventos anteriores que vistos em perspectiva, não se consideraria como algo mal, ruim, errado, torto. Essa parte da história não interessa as pessoas.

Quanto à nossa Malévola (que escolheu seu próprio nome de Bruxa desse trabalho), a interlocutora guarda lembranças muito negativas em relação ao pai. Nas tentativas de diálogo, a incompreensão se transformava facilmente em discussões e brigas. O pai não conseguia e parecia não querer entender que não se tratava de um "rapaz homossexual", mas de uma moça. Nos últimos meses com o pai ainda vivo ela tentou explicar pela última vez que precisa muito dele.

Pedi a meu pai que me ajudasse a modificar meu nome juridicamente. Eu não usava mais meus documentos oficiais há muitos anos. Não estudava e nem trabalhava por medo de me expor com os documentos.

[...] Tentei mostrar para meu pai as razões pelas quais eu precisava mudar meu nome para um que fosse feminino, que refletisse quem eu era. Ele não queria que eu fosse mulher... Que eu fosse homossexual, tudo bem. Mas mulher não! Por fim, meu pai me disse que não me ajudaria e, se algum juiz o fizesse ele recorreria. Eu chorei por semanas.

\footnotetext{
${ }^{239}$ Ver em: http://videos.disney.com.br/ver/trailer-malevola-4f4fc75399c69f9586cb6863 Último acesso em: 16/05/15.
} 
Nos primeiros meses de 2011, Malévola pediu-me que a ajudasse juridicamente na ação de alteração de prenome. Em 2012 ela obteve êxito nos pedidos e conseguiu, finalmente, ter o nome que sempre quis desde menina. A sentença ${ }^{240}$, como discutida no primeiro capítulo, contem muitos equívocos quanto à identidade da interlocutora, desconsiderando peremptoriamente o que a sujeita diz de si própria. Naquele documento ela é "ele" e "o transexual". Mas a identidade "tampão" - "transexual" - como relata, não foi o pior. No cartório localizado em um munícipio do estado do Maranhão/MA onde Malévola foi registrada logo após o nascimento, a ordem judicial para a alteração do prenome, mantendo a modificação "apenas à margem do assento do registro" ${ }^{241}$ foi inteiramente desrespeitada. resultado foi a inscrição ilegítima na certidão de nascimento, no campo "observações/averbações", onde se lê que:

[...] em virtude de sentença datada de xxxxx, oriunda do Juiz de Direito xxxxx, da Vara de Registros Públicos da Comarca de Brasília - DF, nos Autos de alteração de nome no xxxxx, fica o presente termo Retificado quanto ao nome do Requerente para xxxxxx. $2^{\underline{a}}$ via.

Grafada como está a certidão de nascimento expõe a intimidade da sujeita para quem tiver acesso ao documento ${ }^{242}$.Tal situação, além de lembrar os rituais públicos de humilhação, provoca-lhe indignação:

Certeza que a pessoa fez de maldade. Porque está escrito lá, está claro! [refere-se à ordem judicial para que não constasse em nenhum campo da certidão que houve alteração]. Eu tenho muita vontade de sair daqui, ir ao Maranhão, olhar para a cara dessa mulher e falar assim: - "Olha para mim! Olha pra mim!" - Antes de falar qualquer coisa para ela. Dizer: - "Minha senhora, olha para mim! A senhora está vendo o que?" - "Ah estou vendo uma mulher!" (resposta imaginária da mulher).

\footnotetext{
${ }^{240}$ Ver trechos da petição inicial e da sentença nas páginas 27 e 28.

241 Relembrando o capítulo inicial, atualmente é comum no entendimento dos juízes que as informações sobre a alteração de prenome e/ou gênero nessas situações fiquem averbadas apenas "à margem", ou seja, no canto do livro original de nascimento e jamais na certidão de nascimento que é o documento que a sujeita terá de utilizar na sua vida social e jurídica. Quando algum agente estatal comete o erro de gravar nas certidões é possível ajuizar ação de retirada das informações proibidas, acompanhada ou não do pedido por danos morais, para preservar a intimidade da requerente e tentar reparar os danos, quando possível.

${ }^{242}$ Para confeccionar novo RG, CPF, Título de eleitor, carteira de trabalho, passaporte, etc, ela necessariamente teve de deixar cópias da certidão de nascimento em todos aqueles órgãos públicos para efetuar a troca do prenome naqueles documentos. Em razão do erro cartorial, alguns dos documentos da interlocutora mencionam os dados da ação de alteração de prenome, equivocadamente.
} 
[...] Tira essa merda daí!" Porque sou eu quem vive essa vida! Não é você! Você não sabe nada sobre mim! Nada! Não meta o dedo na minha privacidade! Eu fico irritada! Eu fico muito irritada com isso! É invasão a toda hora!

A espera pela cirurgia tem sido menos tortuosa na atualidade, pois além de estar mais tranquila com a situação, a interlocutora entrou com uma ação para obrigar o Estado a cumprir com a prestação de serviços em saúde, encaminhando Malévola para o "tratamento", cuja consequência é a cirurgia, no Hospital de Clínicas de Porto Alegre/RS (HCPA). Como visto, as consultas têm acontecido e os protocolos estão agora sendo cumpridos.

Enquanto aguarda, ela conheceu um rapaz em uma situação quotidiana. Ambos se interessaram um pelo outro, iniciando um relacionamento amoroso. Porém, de acordo com ela, há limites físicos para o progresso da relação. Malévola teme que ao contar sobre o pênis o amado a trate diferentemente, com agressividade ou a abandone.

E o meu dilema é: contar ou não contar! Eu sei que se falar ele vai passar a procurar caracteres masculinos, automaticamente.

[...] E aí começam todas aquelas cobranças sociais: - "E se alguém desconfiar?" - "E se alguém do passado nos vir?" - "A mãe e a irmã dela vão achar que eu sou viado!" E todas essas paranoias que os homens têm! Tenho certeza de que vai haver distanciamento! Não vai ter mais abraços, nem carinhos.

Questiona-se (e aos outros) porque um órgão corporal, um pênis, tem tamanha importância nesta sociedade.

É um troço que você usa para fazer xixi e para fazer sexo e assim... Gente, qual é a importância? Não sou eu! Não sou eu!

\section{Discussão teórica: Inversão na atribuição de valores sociais (a vivência da identidade e sexualidade mesmo com um pênis).}

No capítulo inicial trouxemos as ideias do historiador Thomas Laqueur (2001) e seu modelo de "sexo único" hierárquico que, em termos históricos, apenas recentemente foi tornado duplo nas instâncias sociais e culturais, com direitos e obrigações radicalmente distintos. O pênis nas palavras do autor é "um símbolo de 
status e não um sinal de alguma outra essência ontológica profundamente arraigada: o sexo real." (: 170).

Para ilustrar a precedência do cultural (gênero) sobre o sexo (órgãos genitais), Laqueur narra a história de Marie de Marcis, que quase fora queimada acusada de transgredir as normas de gênero no século XVII. Na narrativa, Marie foi batizada com nome feminino, chegando à maturidade como uma mulher normal cuja menstruação era atestada por seus patrões. A época do seu julgamento, um médico confirmou a condição de fêmea o que a faria arder nas fogueiras. O problema central era que Marie se apaixonara por outra mulher. Durante as relações sexuais, mostrou a sua parceira que possuía um pênis, o que faria dela, na verdade, um homem. $O$ casal, agora normal, pretendia se casar. Ocorre que mesmo portando um pênis não foi reconhecida publicamente como homem. Ao contrário, foi julgada por sodomia ${ }^{243}$ e condenada. Entretanto, um famoso médico Dr. Jacques Duval ao interceder no caso, provou que era mesmo um pênis externo o que faria com que ela/ele pudesse ter os direitos masculinos. A intervenção de Duval poupou Marie da morte, mas o reconhecimento ao gênero masculino não foi de imediato. $O$ tribunal condenou-a a usar roupas femininas até os vinte e cinco anos e que não mantivesse relações sexuais com nenhum dos sexos enquanto vivesse como mulher. De maneira gradual, a transição para a masculinidade deveria ocorrer. Nos apontamentos de Laqueur:

\begin{abstract}
A séria preocupação dos juízes nesse caso não parecia ser com o sexo, mas com o gênero; que sinais de status, que roupas, que posturas Marie podia assumir legitimamente? Apesar da óbvia preocupação da corte com os órgãos, a questão central era se alguém que não nasceu para uma situação mais elevada, alguém que viveu toda a vida como mulher, tinha o necessário para desempenhar legitimamente o papel de homem e, em termos mais gerais, se a "pessoa" tinha direito a um certo lugar na ordem social (: 172).
\end{abstract}

Para as interlocutoras deste trabalho, a narrativa acima é importante para compreender que -ao menos em relação a elas - o pênis tem valor contrário às

\footnotetext{
${ }^{243} \mathrm{Na}$ nota de fim número 42 à página 186, Laqueur explica que a acusação por sodomia de deu porque Marie colocou "[...] o órgão certo no lugar errado, ou o órgão errado no lugar certo, ou o órgão errado no lugar errado. Isso significa que ela foi acusada de colocar o clitóris em qualquer dos orifícios da sua parceira, pois nenhum deles seria apropriado". Não era permitido a uma mulher penetrar outra em quaisquer hipóteses já que estaria tomando o papel dos homens. O crime era o de "penetração ilícita" e a pena a morte pela fogueira.
} 
expectativas sociais que Ihes são direcionadas. Cientes inclusive desse conteúdo de poder, lugar privilegiado e aprovação social, as sujeitas o rejeitam, pois a essência, o pertencimento, é em relação à genitália que comporia à feminilidade. Em outras palavras, para as interlocutoras o pênis é esvaziado do "status" que, nos termos de Laqueur, se equiparava antes do século XVIII, a um simples certificado, dando ao seu portador "certos direitos e privilégios" pela condição (: 170). Para as interlocutoras é o oposto: os atributos sociais desejáveis se confirmariam plenamente com a vulva e a vagina.

Nesse sentindo, dentre as interlocutoras, Malévola é a que mais radicalmente manifesta essa reinterpretação do pênis. Se para ela é um órgão que necessita ser adequado via cirurgia, não significa dizer que não tenha utilidade ou funcionalidade para obtenção de satisfação sexual:

É um troço que você usa para fazer xixi e para fazer sexo e assim... Gente, qual é a importância?

Embora organicamente útil e sexualmente satisfatório, a adequação revalidará a mulher socialmente. Tanto para Malévola quanto para as demais interlocutoras, para além do reconhecimento legal, jurídico, é necessário o reconhecimento em sua dimensão moral, como visto nas obras de Luís Roberto Cardoso de Oliveira.

No entanto uma distinção deve ser feita. A atividade sexual prazerosa com pênis não deve ser fazer com que a sujeita seja confundida com a identidade travesti. Como visto no capítulo inicial, as travestis não se consideram mulheres e abominam a possibilidade da cirurgia.

Assim, a vivência da sexualidade deve ser descolada da identidade da sujeita para a compreensão dessas instâncias diferenciadas. É o que se pretende apresentar com as narrativas de Malévola. 


\section{Cenas de vida.}

\section{A infância singular.}

Malévola teve uma trajetória de vida similar, em algumas partes, às demais interlocutoras: percebeu-se menina muito cedo; manifestou aos familiares o desejo de ser reconhecida como mulher já na infância; cresceu em seu mundo pessoal em casa, cuja vivência completa era interrompida quando obrigada a frequentar as aulas ou ter contatos com estranhos. A singularidade se deu em razão da possibilidade de utilizar expressões artísticas desde muito cedo: desenho, pintura, colagem e trabalhos manuais eram práticas diárias. Dessa forma, ela podia ter muitas vidas, formas e emoções. Com o tempo, sentiu necessidade de transformar o corpo com pinturas, maquilagens, cores e cortes de cabelos, num visual que, segundo ela, poderia ser interpretado como punk-rock-glam. ${ }^{244}$, marca da sua rebeldia e insurgência. Em outros momentos, a "invisibilidade" era buscada com a introspecção para se autoproteger de possíveis ataques do mundo.

Vejo a mim mesma como mulher, sempre! Todos os dias, todas as horas. Quando eu era menina eu sonhava frequentemente que o pinto ia desaparecer... Um dia eu iria acordar e "plim", aquele órgão iria sumir. No lugar dele, apareceria uma linda $x_{x o x o t i n h}{ }^{245}$. Eu assistia aos seriados americanos na TV e sempre me imaginava sendo aquelas heroínas. Cantoras, atrizes, bailarinas, faziam parte do meu mundo. Eu era como elas! Mas quando voltava à realidade dos outros era muito triste. Eu me lembro que tinha por volta de cinco ou seis anos quando eu disse: - "Mãe, eu sou mulher igual as minhas irmãs! Uma mulher comum como qualquer outra." - Eu colocava meu pintinho entre as minhas pernas e puxava bem os shorts para parecer que não havia nada ali. Minha mãe deixava-me livre para brincar de ser menina em casa. Eu inclusive tinha permissão para usar as roupas e sapatos dela em segredo, sem que meu pai soubesse. Porém ela temia que eu sofresse no futuro. Ela repetia: - "Está bem! Pode brincar aqui em casa. Mas saiba que vai sofrer muito na vida... Tenha cuidado! Não vai ser fácil viver assim do jeito que você quer..."

\footnotetext{
${ }^{244}$ Algumas referências iconográficas desses estilos encontram-se em imagens e sons nos álbuns de artistas e bandas, como: Sex Pistols, Ramones, Siouxsie and the Banshees, Culture Club, David Bowie, Cindy Lauper, Laurie Anderson, Grace Jones, entre outros.

${ }^{245}$ Esse trecho da narrativa corrobora a ideia da crença na magia para a modificação da realidade da sujeita.
} 
Quando ia fazer compras, sempre acompanhada de minha mãe, aproveitava para observar tudo ao meu redor. Lembro-me que adorava ir a uma grande loja da cidade e, enquanto minha mãe comprava tecidos, eu pedia a ela que me deixasse ver 0 restante da loja sozinha. A minha visão do mundo era que todos podiam usar o que quisessem. Aquela loja era apenas um lugar neutro, onde as pessoas podiam comprar o que quisessem para si, fossem elas homens ou mulheres. Eu sempre tive experiências frustrantes nessas saídas. Nada do que escolhia, eu podia levar. Pois eram artigos femininos e eu, segundo a minha mãe e os demais, era um menino. Percebi que se eu não obedecesse e não vivesse como um menino, eu teria sérios problemas. Mas dentro de mim, no meu mundo particular, sempre fui mulher!

Houve uma época em eu auxiliava a minha mãe nas costuras. Apesar de ela não querer muito, eu a ajudava descosturando roupas, passando os tecidos e cortando retalhos para fazer tapetes. Eu tinha ainda outras obrigações, pois não tínhamos empregada, então a tarefa de cuidar da casa era dividida entre eu e meu irmão mais novo. Os demais estavam liberados, porque estudavam ou trabalhavam. Nessa época comecei a deixar meu cabelo crescer, customizar minhas roupas, ler muitos livros, revistas sobre moda, música. Tornei-me uma performance ambulante, e consequentemente passei a ser notada pela vizinhança, que logo achou um rótulo para o que estavam vendo: "viado". Mas minha atitude tinha muito mais a ver com o meu mundo interior, meus sentimentos e referências da arte, da música e da moda. Eu não pensava em sexo! Não sabia nada sobre sexo! Então, essa rotulação de "homossexual" ou "gay" era uma falsa visão das pessoas sobre mim, pois nem ter relações sexuais eu tinha ainda...

\section{Adolescência.}

A escola era um pesadelo! Meus sonhos eram sempre desfeitos: na sala de aula, na hora da chamada, com os colegas, no banheiro, no recreio... Quem eu queria ser tinha de ficar bem escondida, porque quando sabiam eu virava a chacota do colégio, uma aberração! Foram anos me escondendo, sendo torturada todos os dias, tendo de fazer atividades que não me interessavam... Eu cumpria apenas obrigações! Eu procurava de alguma forma ficar invisível ${ }^{246}$ desde o meu primeiro dia de escola.

\footnotetext{
${ }^{246}$ Como destacado na narrativa de Úrsula - A Feiticeira do Mar, a invisibilidade social também era um recurso usado pela interlocutora para não ser notada, percebida ou apontada nos ambientes externos. A invisibilidade como na proposta por Honneth se dá em razão de os demais atores sociais
} 
Quando meu nome era chamado na lista de presença, eu sentia muita vergonha... Queria estar ali, mas com outro nome, sendo reconhecida nos meios femininos!

Fui crescendo e, nesse meio tempo até a adolescência, aperfeiçoei meus métodos de invisibilidade. Encontrei no silêncio uma forma poderosa de me defender dos ataques de familiares, vizinhos e colegas de escola. Eu me tornara uma criança personagem de um filme mudo em preto e branco. Expressava-me através de desenhos, colagens e outras formas artísticas.

Com o passar dos anos a pressão social sobre mim aumentava. Cheguei à conclusão que teria de abandonar meu visual artístico por alguma coisa mais simples, que me fizesse invisível novamente. O dia amanhecia e eu guardava todos meus adereços e acessórios numa caixa e separava as roupas que eu ainda poderia usar nessa nova fase. Despedi-me de tudo, e me desejei sorte...

\section{O sexo (na adolescência).}

Como já apresentado, Malévola desde muito cedo começou uma intensa vida sexual. Mesmo sendo mulher, encontrou prazer e satisfação sexual com o pênis.

Na rua havia dois irmãos da mesma mãe e pai diferentes. Um deles era mecânico, e me chamou a atenção por ser um homem muito bonito, discreto, com um corpo malhado, um tórax peludo e hipnotizantes olhos verdes. O encontro aconteceu por acaso. Eu retornava da casa dos meus avós já bem tarde da noite, havia chovido e não tinha mais ninguém nas ruas. Ao virar uma esquina próxima à minha casa, ouvi um "psiu", e achei que não era comigo, olhei para trás e vi aquela silhueta masculina parada fazendo um movimento com as mãos, me chamando. Voltei e ao chegar mais perto, percebi que era ele. De bermuda, chinelo, tórax desnudo e camisa no ombro, segurou minha mão e disse: - "Boa noite! Podemos dar uma volta?" Ele colocou a mão em volta da minha cintura e eu na dele, juntinhos fomos caminhando sem um destino certo. Paramos numa escola que estava em obras. Lá ele tirou a roupa e nu, falou: - "Sou todo seu!" Comecei a acariciar o tórax peludo, fui tirando minha roupa e inteiramente nua, me esfreguei muito naqueles pelos. Ele, notando a 
minha excitação, falou: - "Grelo já durinho, né safada?” E segurando firme meu pênis, me fez um delicioso sexo oral! Apalpei todas as partes daquele corpo malhado, firme, suado e aproveitei bastante. Ele retribuía minhas carícias com longos beijos, lambidas, mordidinhas. Era um sonho estar com aquele homem todinho só para mim. Fiz um sexo oral muito intenso nele! Sentir aqueles pelos arrepiados foi a melhor resposta de aprovação que eu podia esperar. Era a primeira vez que eu fazia sexo ao ar livre, mas me sentia segura com ele. Foi intenso, sai com os joelhos ralados, mas inteiramente feliz e satisfeita!

\section{Hormônios e transformações corporais.}

Quando a adolescência chegou, percebi que o pênis não sumiria. Lá pelos meus 14 anos os hormônios masculinos começaram a mudar drasticamente meu corpo. E eu não conhecia nenhuma forma de bloquear a ação dos hormônios masculinos, mas precisava urgentemente. Pouco antes de eu completar 18 anos, alguém me falou que eu conseguiria me feminizar se tomasse diariamente anticoncepcionais femininos. ${ }^{247}$ Foi o que eu fiz! No começo tomava quase uma cartela inteira de 28 comprimidos por dia! Depois, aprendi a regular as dosagens, anotando num caderno todos os detalhes para conseguir os efeitos pretendidos. Não demorou até que meus seios começassem a crescer, os pelos do rosto e corpo diminuíssem e minha silhueta se arredondar. Além dos efeitos no corpo, ao menos comigo, percebia que o estradiol mexia com as minhas emoções. Eu me tornava mais sensível e mais irritada também. Porém, não estou certa de que a irritabilidade vinha dos hormônios, pois eu estava passando por um momento muito difícil com as emoções à flor da pele e as dificuldades sociais de não ter documentos, estudo, trabalho, etc.

O uso dos hormônios antes dos 18 anos, fez com que eu conseguisse me manter mais feminina. Porém, se eu tivesse tido acesso e conhecimentos antes, no começo da puberdade, teria evitado alguns caracteres masculinos que hoje me incomodam.

\footnotetext{
${ }^{247}$ Malévola disse-me que utilizou por muitos anos, diversas marcas de anticoncepcionais femininos em pílulas que continham o princípio ativo "etinilestradiol", espécie de estrogênio sintético, hormônio produzido nos ovários. Hoje ela utiliza estrógenos conjugados combinados com betabloqueadores, como o "acetato de ciproterona" (para coibir os efeitos da testosterona). Durante todos esses anos ela não teve acompanhamento médico. Nos últimos dois anos, tem sido acompanhada por endocrinologista particular.
} 


\section{Conflitos com o pai.}

Se nas demais interlocutoras a figura paterna quase não aparece nas narrativas ${ }^{248}$, Malévola tem memórias muito vivas da relação, em regra conflituosa, com o pai. Ele era advogado e, separado da mãe da interlocutora, já vivia nova relação com outra mulher e os filhos dela. Vítima de um infarto, o falecimento repentino ocorreu há cerca de 10 anos, deixando interrompidas as esperanças de um entendimento verdadeiro entre pai e filha, nunca plenamente possível. Assim, as saudades, as mágoas, as emoções e decepções ainda estão presentes e aparecem muito vivas nesses trechos escritos.

Pedi a meu pai que me ajudasse a modificar meu nome juridicamente. Eu não usava mais meus documentos oficiais há muitos anos. Não estudava e nem trabalhava por medo de me expor com os documentos. Sempre inventava desculpas para não portar o RG: que tinha perdido; que havia sido roubada, etc. Não aguentava mais ser chamada de "fulano" sem efetivamente ser "ele". Tentei mostrar para meu pai as razões pelas quais eu precisava mudar meu nome para um que fosse feminino, que refletisse quem eu era. Ele não queria que eu fosse mulher... Que eu fosse homossexual, tudo bem. Mas mulher não! Por fim, meu pai me disse que não me ajudaria e, se algum juiz o fizesse, ele recorreria. Eu chorei por semanas.

Noutra ocasião, falaram para o meu pai que eu havia transado com um rapaz que morava na rua e que, além disso, andava fumando maconha. Não fui em nenhum momento questionada sobre a veracidade dessas informações. Meu pai armou uma cena, juntamente com minha mãe para me punir. Mandaram meu irmão mais novo para a casa dos meus avós, e eu me vi sozinha com eles. Meu pai então ordenou que eu ficasse de joelhos diante dele e da minha mãe, e com uma corda nas mãos, ia falando tudo o que haviam dito para ele. Disse que "filho" dele não era viado e nem usava drogas. Diante daquele monte de mentiras inventadas ao meu respeito, foi crescendo uma raiva tão grande, que acabei confirmando tudo. Apanhei muito por isso. E a cada golpe de corda ele perguntava:

\footnotetext{
${ }^{248}$ Relembrando: com a Bruxa Malvado do Oeste o pai inexiste; nas memórias de Úrsula - a Feiticeira do Mar o pai tem pouquíssima importância e na trajetória de Maga Patalógica o pai é mero detalhe nas relações matriciais. A ausência de menção paterna naquelas sujeitas se contrasta com a ênfase no desejo de compreensão e afeto demandado por Malévola ao pai. Uma possível interpretação poderia ser a falta de perguntas direcionadas que evocassem lembranças paternas ou mesmo que não sentiram vontade ou empatia suficientes para narrar alguma história com o pai.
} 
- "Você gosta de homens?"

Eu respondi gritando de ódio:- Gosto!!!

- "Você transou com homem?"

- Transei!!!

- "Você fumou maconha?"

- Fumei a porra da maconha!!!

E a cada resposta a força empregada era maior. Não verti uma lágrima sequer enquanto apanhava. Só chorei quando minha mãe veio despejar água com sal nas minhas costas, para minimizar o inchaço e a dor. Não dormi aquela noite pensando no que fazer para me proteger daqui em diante.

Voltei a ficar retraída. Só que dessa vez além de monossilábica, eu agora também era dissimulada. Pensava em me vingar dos meus pais, sem que eles soubessem. $E$ consegui. Comecei a flertar discretamente com um amigo do meu pai. Ele era professor de matemática e mais de dez anos mais velho que eu (ela tinha 14 anos; ele, 26). Apaixonamo-nos um pelo outro. Era uma relação muito tranquila e nem nos preocupávamos em sermos descobertos. A rua inteira sabia de nós dois menos meus familiares. Namorávamos em praça pública e íamos aos cabarés da zona de meretrício para ficarmos mais à vontade. Lá na zona, com as "mulheres da vida" troquei ideias, informações sobre sexo, e aprendi a fazer minha limpeza, para poder fazer um sexo anal limpo. Elas me chamavam de "menininha perigosa". Dessa relação ficou na minha memória um hábito dele, que era cantarolar a mesma canção todas as vezes que se aproximava de mim. Ele dizia que era pra ficar eternamente na memória. E ficou... ${ }^{249} E$ assim, cumpri minha vingança e com esse rapaz tive minha primeira relação sexual, descobrindo o corpo masculino e os prazeres que um homem pode proporcionar a uma mulher, ainda que com um pênis.

\section{Você acredita que seu pai amava você?}

Ahh...! (longa pausa) Sim! Hoje eu acredito que sim! Mas na época eu achava que não. Sabe como é, homem nordestino, com valores machistas muito fortes, rude. Não dava para acreditar. Nós conversávamos às vezes e nem sempre com grosserias, porém quando eu queria dividir alguma coisa da minha vida, ele já

\footnotetext{
${ }^{249}$ Malévola cantarola: "Um amor assim delicado, você pega e despreza. Não devia ter despertado. Ajoelha e não reza..." ("Queixa" de Caetano Veloso).
} 
fechava a cara. Dizia que era besteira sem nem ouvir direito. Que tudo que eu falava era bobagem. Nos últimos anos estávamos nos aproximando mais... Ele até conseguia deixar escapar um "minha fila", ou mesmo "Malévola", quando estávamos com visitas em casa. Meu pai era muito importante para mim! E sei que se preocupava comigo, com o que de mal pudesse me acontecer. Mas eu gostaria que ele tivesse compreendido e amado quem eu era de verdade...

\section{O que é ser mulher? (“Uma força que gera, que modifica as coisas!”).}

Perguntei à interlocutora o que ela entende por ser mulher num contexto social e na sua perspectiva particular. À semelhança com Maga Patalógica e Úrsula - A Feiticeira do Mar, Malévola percebe as mulheres, em termos de "essência". Para essa interlocutora a essência se traduz em "uma força". Mas não qualquer força e sim, "A Força", aquela que gera e movimenta a vida. Mesmo se considerando mulher e, consequentemente, portadora Da Força, ela crê que com a vagina terá ainda mais força.

Observando os preconceitos e as concepções sociais que estão aí estabelecidas, a gente já sabe, né? Aquela que cuida da casa: cozinha, passa, limpa, etc. A que satisfaz os homens e bla, blá, E todos esses problemas que a gente tem que passar nessa sociedade [se refere ao machismo]. Agora essencialmente, eu acho que é uma força. "A Força", uma força que gera, que modifica as coisas! Algo que eu não vejo nos homens... Os homens têm uma força, evidentemente, mas acho que são empurrados por alguém... Sabe uma marionete? (risos) Eu vejo os homens assim! Pelo menos os homens da minha família. Foram as mulheres que levantaram, que empurraram para frente a família inteira. Que criaram tudo! Que fizeram esse movimento de sair do Maranhão. Foram as mulheres! Os homens, não! Foi a minha tia que veio para cá e trouxe meus irmãos. Depois eu vim, visitei, gostei e voltei definitivamente. Mas ela é precursora em tudo! E a minha mãe também, porque ela sempre estudou e trabalhou muito. E sempre exercitou esses trabalhos manuais, esses dons. Esse cuidado que eu tenho com a casa e com os trabalhos manuais vem dela. A minha avó também costurava, bordava, mas não tanto quanto a minha mãe. Agora, o lado boêmio, da sexualidade, da liberdade, é da minha avó! Porque ela gostava de uma festa... 
Quanto a mim, sinto-me mulher. E hoje inteiramente mulher com o pinto e tudo! (risos) Mas gostaria que não estivesse aqui (o pênis). Socialmente, eu me sinto tranquila, ali na rua, interagindo com as outras pessoas. A grande questão é a intimidade. O genital que precisa ser alterado. E essa alteração fará diferença para o meu corpo, para mim, para minha intimidade. Agora para o público continuarei sendo a mesma pessoa. Apesar de eu também ter essa força, acho que talvez a mudança vá me trazer mais liberdade, mais força!

\section{Deseja ser vista e reconhecida como mulher? (Dilemas da identidade).}

As dificuldades do reconhecimento como explicitado no capítulo inicial também incomodam Malévola. Se por um lado percebe-se reconhecida nos ambientes sociais e, como se verá adiante, a alteração judicial do prenome auxiliou em muito nesse reconhecimento; por outro, com os parceiros na intimidade há ainda alguma dissintonia na percepção da identidade de mulher vivida pela sujeita que não se alinha plenamente com a visão do outro sobre ela, em razão da presença de um pênis. Ela traduz esse mal-estar como um "porém". Assim, como uma estratégia para alertar ao outro desconhecido, em situações muito específicas, a interlocutora utiliza o termo "transexual" não porque se identifica com ele, mas para comunicar que embora seja mulher, ainda possui um pênis entre as pernas, caso o encontro progrida para relações afetivas e sexuais. Essa adaptação do discurso se dá em razão do senso comum que, assim como a medicina, a psicologia e o direito, entendem que uma "mulher com um pênis" é o mesmo que uma "transexual". Entretanto, Maléfica está perfeitamente consciente de que "transexual" não é sua identidade real. $O$ manejo do termo pela sujeita nestes casos pode ser compreendido como um dilema. ${ }^{250}$

Sim! Sou reconhecida na verdade. Já vivo isso! Mas quando vai para o lado íntimo... Meu único problema agora é com essa coisa da intimidade! Eu não posso chegar num cara e falar assim: - "Sou mulher da forma como se conhece uma mulher, com

${ }^{250}$ O "Dicionário Online de Português" define um dilema como "Circunstância árdua e de difícil resolução em que é necessário escolher entre duas opções contraditórias, contrárias ou insatisfatórias; escolha excessivamente difícil". Mais a frente pretende-se esclarecer em que aspectos esse dilema aparece mais frequentemente nas falas da interlocutora.

Ver em: http://www.dicio.com.br/dilema/

Último acesso em: 16/05/15. 
vagina. Sou uma mulher, mas ainda tenho pênis!" Então, para ele, não é uma mulher! Por mais que os caras falem: - "Ah! Eu reconheço você como mulher. Te respeito como mulher." Eu sinto sempre um "porém". De dizer: - "Ah! Mas ela tem um pinto. Quem tem pinto não é homem? Que mulher é essa com pênis?" Daí, às vezes, você é obrigada a usar outra palavra...

\section{Que palavra?}

"Transexual". Que hoje infelizmente tem sido usada como sinônimo de "mulher com pênis", mas é equivocada por que direciona você a outra identidade. Além do mais, sinaliza nos caras que você está a fim de sexo. Eu te falo porque converso com muita gente pela internet. A palavra "transexual" é igual àquela que está atrás de sexo e ponto! Não existe outra coisa. É sempre igual a sexo! Se você não direcionar a conversa para outros caminhos, fica no sexo. Aí, depois que a pessoa passa a conversar direito com você. E principalmente comigo porque eu ataco as pessoas... Posso até dizer que eu sou bem agressiva com texto na internet. Porque eu ataco! Eu falo: estou aqui me identificando como "transexual" para não "enganar" [coloca um entre aspas no termo] as pessoas. Porque aqui eu não estou vendo a cara de ninguém. Entendeu? Eu não quero chegar e conhecer um cara: - "Ah! Mas você falou que você era mulher... E você tem um pinto?!? Você não é mulher!" Além de tudo, eu corro um monte de riscos de violências e tal. Tenho colocado isso quando entro no chat [sala de bate-papos da internet]para a pessoa já saber o que pode haver na intimidade.

\section{Malévola, então, você utiliza a palavra "transexual" para explicar que você ainda tem um pênis?}

É. Mas só na internet! O que eu acho péssimo, que não precisava! Ela não é uma identidade! É uma estratégia, para não ter de ficar explicando muito as coisas. Para que eu não frustre o outro e não me decepcione com o que o outro vai achar de mim. E hoje ainda mais por questões de segurança. Sabe? Eu faço isso muito por questões de segurança. Se o cara se sentir engando, ainda que não seja minha intensão, pode ser violento. Nunca se sabe. 


\section{Então, você não usa o termo ou o conceito "transexual" porque reflita a sua identidade vivida no dia a dia?}

Não! Jamais! É para que a pessoa compreenda que ainda tem um pênis ali. Daí, o cara diz: - "Quero ou não quero!" Essa coisa de "transexual" já está no domínio popular. Porque para eles a "transexual" é superfeminina. Mais feminina que a travesti, mas não é mulher. Fica sempre nessa coisa exótica: é melhorzinha do que a travesti, mas ainda não é uma mulher. (risos) Então, eu só uso essa palavra para isso. Porque a internet não é um lugar onde você vê diretamente o rosto das pessoas. E também, na vida social você não tira a roupa, né? Você não anda nua para as pessoas verem sua genitália. Mas se eu já estivesse com a minha vagina, seria meu nome, qualquer nome, qualquer outro nick [name] feminino sem "trans" no meio!

\section{Diferenças entre a interlocutora e outras mulheres que não necessitaram de cirurgia genital.}

Só mesmo o genital! De resto, não vejo diferença nenhuma! Não me sinto melhor ou pior do que qualquer outra. Sinto-me igual, pertencente ao grupo feminino na sociedade. A única diferença realmente é ter um pênis. E é física! Que para mim também só é diferente nos encontros que a gente tem com o outro e ele não sabe...(pausa)E também é um problema dele! É um problema do outro que não consegue entender, não quer compreender. A vivência dele que nunca teve contato com esse tipo de diferença... Sei lá... Não é um problema meu! Então, eu não tenho muito que falar sobre isso. Comigo mesma estou tranquilíssima!

\section{Filhos e procriação.}

Eu não acho que mulheres tenham necessariamente que procriar, ter filhos. Para mim a maternidade pode ser realizada de várias formas! $!^{251}$ Não necessariamente com filhos humanos. No meu caso a maternidade veio pelos gatos (ela tem dois gatos). E também no caso de cuidar da família, da minha mãe, da casa. Sinceramente, eu não sei te dizer se tivesse nascido com todo o aparelho orgânico

\footnotetext{
${ }^{251}$ Interessante refletir que o desejo pela maternidade não é unanimidade entre as interlocutoras. Bruxa Malvada do Oeste sonhava se tornar mãe, mas após a cirurgia mudou sua forma de pensar. Úrsula desejaria ter filhos paridos de si desde que nascida com aparatos orgânicos. Já Maga patalógica é mãe e não vê diferença entre filhos nascidos e filhos criados.
} 
feminino, se eu teria mudado minha percepção sobre essas coisas. Mas eu acho que não! Não me vejo hoje na maternidade que está por aí... Talvez a impossibilidade de realizar [refere-se a parir] tenha feito com que eu tenha essa visão. Eu não sei... Esse espírito gerador, mantenedor, isso para mim é mais importante que o filho em si! Essa coisa tradicional, da família, do filho gerado... Não sei. Acho que a maternidade pode ser resolvida de várias formas!

\section{Relacionamentos afetivos e sexuais hoje.}

Malévola afirma sempre ter praticado muitas relações sexuais. Sua sexualidade parece ter sido livre e intensa desde os 14 anos de idade. Se a identidade da sujeita foi certa e definida; a sexualidade tem sido uma constante experimentação. Apesar dos momentos de angústias e dificuldades, o pênis parece não ter sido um problema que a impedisse de viver a sexualidade plenamente ${ }^{252}$. Foi casada por oito anos. Namorou diversos homens. Manteve, inclusive, diversos relacionamentos paralelos. Hoje namora um rapaz e tem vários ficantes.

Relacionamentos? Bom, tenho vários... (risos) De qual etnia você quer saber? (gargalhadas). Tenho um namorado atualmente e a gente se dá bem. Tem uns problemas dele... Assim, tem mais problemas dele do que meus. Eu sou muito mais bem resolvida do que ele nessas questões sociais. Mas nos damos bem: ele é muito carinhoso e a gente consegue se entender. O sexo é bom, só que ele não me acompanha sexualmente tanto quanto eu gostaria que me acompanhasse... Porém, acho que é questão de falta de tempo e de gosto, também, né? Cada um tem os seus gostos! E ficantes eu tenho alguns para os momentos que não estou fazendo nada e dá aquele tesão... (risos) Se o namorado não está disponível, tem outros disponíveis! (risos)Mas tudo muito tranquilo, sabe? São pessoas muito respeitosas. Posso ate dizer que são pessoas muito carinhosas. Já fui mais devassa... De sair catando todo mundo. Hoje em dia não. Tive uns caras que apareceram do tipo assim: - "Ah quero que você me coma!" Eu disse: como! - "Ah quero que você me

\footnotetext{
${ }^{252}$ Aqui é interessante pensar nas narrativas de Bruxa Malvada do Oeste e Úrsula - A Feiticeira do Mar. A primeira fala muito pouco das experiências sexuais da adolescência e a segunda afirma claramente não ter sido possível viver a sexualidade no passado.
} 
faça fist fucking 253 !" - Faço! E tem muita coisa que fica só no papo: - "Queria que você me comesse..." E na hora acaba a transa e nem rola nada, porque o cara se satisfaz com outras coisas.

Quanto ao passado, não tenho mais tantos conflitos quanto tinha antes. Uma coisa que eu estava refletindo outro dia: a minha vida sexual foi intensa, foi ótima! Acredito que quando eu tiver uma vagina vai ser melhor ainda. Porém, não tenho nada a reclamar em relação a sexo, não! Nem do casamento, nem dos relacionamentos afetivos, nem nada, nada, nada. Meus namorados sempre foram maravilhosos comigo. E Eu sempre gostei muito de sexo! Estou realizada sexualmente e pronto! Sei de histórias em que as pessoas têm conflitos com o corpo, com sexo. Porém ao contrário, minha vida afetiva e sexual sempre foi muito boa. Nesse ponto não tenho problemas. Nunca tive! Eu fui me conhecendo, fui me adaptando. Quem queria chupar, chupava (gargalhadas). Quem não queria, não chupava. Tudo ia ao sabor de quem aparecia e do que eu gostava, também. Eu só informo: existe um pênis. "Ah, eu gosto de chupar!" Então, chupe meu filho! (risos).

Uma vez eu comi um cara com o vibrador dele! Era um negócio desse tamanho (faz um sinal com as mãos indicando o tamanho do objeto) eu fiquei estupefata! Eu não aguentaria grande daquele jeito! Meti, meti, meti e ele quase não se mexia... (gargalhadas). Juro! Quase não se mexia e eu metendo o negócio até o cabo e ele nada. Quando eu terminei, ele virou tranquilamente e falou assim: - "Ué já terminou?" - Terminei! Estou cansada! Estou mexendo aqui com o braço e tu não se mexe. (risos, gargalhadas) "Mas eu estava gostando bastante..." A meu filho, então dá algum sinal de vida, se mexe, sei lá! (gargalhadas) Olha, a vida inteira eu dei o cu e nunca fiquei desse jeito... (gargalhadas). Completamente indiferente... Um negócio daquele tamanho se não entrasse com cuidado, eu morderia o travesseiro de dor... (risos).

\section{Conhecer alguém hoje. (A excessiva importância de um genital!).}

Eu conheci um rapaz no curso de inglês. E na primeira aula, senti esse rapaz me observando. Ele viajou para a Argentina de férias. E quando voltou, trouxe-me um

\footnotetext{
${ }^{253}$ Prática sexual que consiste em introduzir a mão ou o antebraço no ânus ou vagina, aprendendo a ter prazer nas sensações provocadas pela distensão daqueles órgãos. Ver em: http://pt.wikipedia.org/wiki/Fisting Último acesso em: 16/05/15.
} 
alfajor. Trouxe um para cada pessoa da turma. Não sei por que diabos, eu guardei a embalagem. Tenho até hoje. Na aula seguinte, era a dia do meu aniversário. E a professora falou para ele que era meu aniversário. Eu quis fugir do constrangimento (risos). No que eu tentei escapar, ele vinha subindo as escadas: - "Você pode voltar que vamos cantar os parabéns! Você vai comer um bolo que eu mesmo fiz!" Ele faz uns bolos maravilhosos! Enfim, comemoramos meu aniversário. Depois, ele me perguntou: - "Quer tomar um café comigo?" Fomos. No café ele me contou a vida todinha. Eu contei a minha quase toda. Só não os detalhes... (risos) Ficamos conversando até nove da noite. Nas aulas, fomos nos aproximando. Isso já tem uns três meses... E nas conversas a gente está numa intimidade tremenda. Todas as vezes que a gente se encontra, sentimos que tem alguma coisa, algum tipo de sentimento. Não sei se vai chegar a alguma coisa sexual. Pode ser que sim, porque ele tem uma energia sexual muito forte e eu também. E aí a gente fica nessa brincadeira. E o meu dilema é: contar ou não contar! Eu sei que se falar ele vai passar a procurar caracteres masculinos, automaticamente. Procurar os caracteres para justificar o pinto. Então, vai me esquadrinhar para ver onde é que tem alguma coisa de homem e tal. E aí começam todas aquelas cobranças sociais: - "E se alguém desconfiar?" - "E se alguém do passado nos vir?" - "A mãe e a irmã dela vão achar que eu sou viado!" E todas essas paranoias que os homens têm! Tenho certeza de que vai haver distanciamento! Não vai ter mais abraços, nem carinhos. Para mim isso é muito mais importante do que a coisa sexual. Eu não posso concretizar o desejo sexual, porque se eu contar, ele vai mudar comigo. Ele não vai mais me ver como mulher... Não serei mais apresentada à mãe dele; não participarei da vida social dele, nem apresentada aos amigos e amigas; ele não vai me levar para lugares, sair, convites para viajar, de todas essas coisas, entendeu? O meu ganho talvez seja ficar em silêncio sobre isso. E ganhar a minha liberdade como amiga íntima, como mulher, tendo um espaço social, que eu não vou ter se eu contar. E para mim isso é mais valioso do que transar com ele!

\section{Com a cirurgia. ("Você me enganou!").}

E mesmo com a cirurgia, se você contar que um dia existiu um pinto, volta no cérebro do cara a procurar os caracteres masculinos: - "Ah! Mas acho que isso não é 
coisa de mulher!" - "Seu comportamento... Porque você é muito decidida, muito agressiva, muito objetiva, muito direta... Isso não é de mulher!" Aí começam a aparecer essas justificativas, para essa coisa de "um dia já teve". E a coisa mais ridícula é que tudo isso é por causa de um genital! Por que um genital tem essa importância toda?? Sabe? É um troço que você usa para fazer xixi e para fazer sexo e assim... Gente, qual é a importância? Não sou eu! Não sou eu! É apenas uma coisa que existe no corpo! Mas, muda tudo! E aí estou nesse dilema: se conto, perco toda a liberdade, a naturalidade da relação. Perco inclusive o amigo! Perco também todas essas coisas, tudo que eu consegui, por conta de querer ser justa e ser legal e não ser mentirosa... Sem falar que ser justa não vai funcionar na hora. É capaz de o cara ainda falar assim: - "Você me enganou!" "Você não falou que tinha um pau..." Porém, isso não tem menor importância! Não tem a menor importância! Meu pênis não é um "cartão de visitas"! Mas as pessoas se portam como se eu tivesse que dizer a todo o momento: - "Desculpa... Eu tenho um pênis!"

\section{O rapaz. (De como ter um pênis incomoda mais ao outro do que a si mesma!)}

O afeto amoroso pelo rapaz que não sabe ainda da presença de um pênis no corpo da interlocutora e a possibilidade de ser obrigada a contar, tem angustiado Malévola. Em sua predição, não apenas o rapaz reagirá mal ou simplesmente a abandonará, como também se sentirá enganado. Entretanto, pelos cálculos da sujeita, o fato de haver um pênis (ou ter havido, casa haja feito a cirurgia) perturbará muito mais a ele, pois erradamente o sujeito se autoquestionará sobre uma homossexualidade por parte dele, o que nada tem a ver com o problema da sujeita com ela mesma. Assim, a cortesia e os atos de conquista serão provas da percepção da "fraude", pois se soubesse que "não era mulher", não teria investido tanto em afagos galanteadores.

Ele vai esquecer todas as nossas conversas, tudo que passamos. Ele vai me esquecer! Vai ficar muito puto comigo porque ele me mandou fotos quase pelado. Vai achar que eu o enganei, que eu sou um "viado desgraçado"! Que eu sou uma "fraude"! E que as pessoas que me viram com ele podem estar rindo dele nesse momento... (pausa) E vai ficar ainda mais puto porque ele pagou todos os almoços e todas as sessões de cinema para alguém que tinha um pinto. (pausa) Entendeu? (pausa seguida de uma longa inspiração) Eu não sei também. Estou falando isso, 
mas não sei até que ponto ele tem essa visão deturpada. Creio que pelo fato de ser muito jovem (23 anos), não vá ter essa maturidade toda, nem esse conhecimento... Conhecimento sobre isso eu sei que ele não tem. Ele vai começar a abrir a mente agora... Se eu contar para ele, talvez ele vá começar a entender! E eu não sei se eu quero correr esse risco. Só o faria numa situação de limite sexual, que não tem para onde correr. Daí, eu falaria: - "Meu amigo! O negócio é o seguinte: eu tenho um pênis!" (risos)Eu continuaria sendo a mesma pessoa. Só que para ele, na hora em que ouvir a frase "eu tenho pênis", o cérebro é instantâneo: vai mudar comigo! A pessoa te olha com outros olhos, vem toda a carga de marginalidade, de gueto... Por mais que o cara te conheça. Que você tenha uma profissão, seja ótima no que faz, que todo mundo te reconheça, que todo mundo te trate[como mulher]. Ele Já viu isso! Já teve provas disso nas aulas de inglês! Mesmo assim, a paranoia vai se plantar naquele momento. A paranoia dele com ele mesmo! Porque se eu disser que tenho uma questão no meu corpo, vai fazer com que ele pense de si como gay, ou homossexual, sei lá. Então, na cabeça dele, apesar de eu falar de mim, vou expor a ele. Olha que coisa doida?!

\section{Militância LGBTTT e academia "Queer".}

À exceção da Úrsula - a Feiticeira do Mar, as demais interlocutoras participaram de eventos promovidos pela militância LGBTTT em algum momento de suas vidas. Malévola, então com 20 e poucos anos de idade, acreditando que ao expor a sua história de vida publicamente conseguiria caminhos para a cirurgia e a troca de nome, buscou ajuda num grupo de ativistas daquelas identidades. Acabou despertando o interesse também dos acadêmicos adeptos das teorias Queer e das "TransRevolucionária"254 que lhe prometiam emprego e ajuda médico-cirúrgica em troca de entrevistas e depoimentos em diversos estudos, teses e trabalhos acadêmicos, sem nenhum cuidado ou interesse em realmente ajudá-la. Em ambas as situações, Malévola conheceu a mentira e a decepção. Foi usada por pessoas e grupos que viam nela uma chance de autopromoção, dada à trajetória de extraordinária sobrevivência. Poucos anos depois, desenganada, desempregada e ainda sem obter êxito nas suas questões primordiais, abandonou aqueles grupos e o

\footnotetext{
${ }^{254}$ Como visto no capítulo inicial às páginas $49-58$.
} 
convívio com os acadêmicos interesseiros, passando, em seus termos, a "enfrentar a vida sozinha". Esse tópico contem trechos de relatos escritos por ela numa carta redigida anos depois das situações vividas. Efetuamos modificações para manter a carga emotiva do texto sem abrir mão dos cuidados na proteção da identidade da interlocutora.

Através de uma amiga à época conheci a militância LGBTTT. Colaborei com diversas causas utilizando-me da minha história pessoal, inclusive com meu nome verdadeiro publicizado. Diziam que iriam me ajudar a conseguir minha cirurgia e alterar meus documentos, que eram as coisas mais importantes para mim. Fui percebendo aos poucos que era tudo mentira: eu assumiria publicamente uma identidade "trans", renegando meus sentimentos de ser mulher, para dar "visibilidade à causa de travestis, transexuais e transgêneros", já que elas são raras nos movimentos LGBTTT. Aceitei porque estava desempregada, sem dinheiro e sem perspectivas de conseguir sozinha realizar meus sonhos de ser finalmente mulher normal e completa. Expus-me em jornais, programas de TV, eventos públicos. Perdi as contas de quantos trabalhos acadêmicos contribui e ajudei a escrever, inclusive. Dei minha vida real às especulações de pesquisadores que com isso lucraram com títulos, diplomas, vendagens de livros... Sem me dar conta, eu havia "virado" "trans". A palavra das pessoas ao meu respeito estava agora na minha boca e era mais importante que a minha. Para conseguir meu sonho, me tornei minha pior inimiga! Eu chegava em casa e não me reconhecia. Aquela "trans" não era eu! Não era assim que a minha mãe e meu pai me conheceram no passado. Não era assim que eu me acreditava ser de verdade. Era uma mentira para agradar aos outros! Introjetei uma imagem "revolucionária" que os outros esperavam de mim. Os LGBTTT e os acadêmicos me "aprovavam", se surpreendiam, realizavam-se em mim! Ficavam felizes pela "comprovação" das suas teorias. Eu me conformei porque ao menos essa falsa aprovação me fazia me sentir amada, querida, especial...

O pior de tudo é que eu não saía do lugar. Sempre inventavam desculpas para não me remunerar em projetos na ONG, não havia tempo para resolver meus problemas e dificuldades. Eu nunca consegui absolutamente nada revelando a minha vida daquela maneira! Ao contrário, quanto mais eu falava mais na merda eu ficava! Cheguei a viver da ajuda da minha família e de amigos para pagar as contas, comer, sobreviver. Uma vez pedi emprego a uma acadêmica assessora parlamentar que 
pouco antes havia me instigado a dar um depoimento em jornal. Ela me respondeu que não poderia me ajudar porque o patrão dela não queria ter sua imagem vinculada a uma "trans". Ela sabia disso, mas mesmo assim pediu que eu fosse a publico contar minha história... Larguei aquela vida que não me pertencia, mas não sem antes me afundar ainda mais! Perdi as contas de quantas vezes implorei, me submeti, me humilhei... Cheguei a odiar a mim mesma depois por tanta ingenuidade, em achar que eles se interessavam realmente por mim...Mas isso já tem quase 10 anos. Está no passado! Que fique lá! Aprendi que tenho de caminhar e enfrentar a vida sozinha! Sem grupos, movimentos, organizações.

\section{Alteração de prenome.}

Como já dito, a interlocutora obteve êxito na ação judicial para a alteração do prenome ${ }^{255}$. Essa mudança de âmbito civil proporcionou mais conforto $e$ liberdade socialmente. Após essa importante alteração, ela pode escolher se e a quem revelar alguns pontos de sua trajetória. Para Malévola significou "nascer novamente". Entretanto, a ausência de sigilo, tanto do nome anterior quanto em relação a alguma modificação genital, é vivida como um grande problema para a sujeita, pois não resguarda a sua intimidade da curiosidade e da maldade alheia. Ao expor alguém dessa forma "estragam a vida da pessoa toda!"

A alteração de prenome faz toda a diferença! Com certeza! Nossa... É nascer novamente! Te dá uma segurança social, uma estabilidade. Eu não tenho mais receio de ir para lugar algum hoje! Algum lugar que precise mostrar documentos. E mesmo na polícia também, sabe? Fui lá, fiz meu papel de cidadã, sou uma senhora, fui tratada como senhora e ponto final.[Refere-se ao registro de boletim de ocorrência em razão dos documentos terem sido furtados recentemente]Agora, se alguém viesse falar "o", "o senhor", eu ia corrigir na hora: - Mas porque isso está escrito aí...?Não interessa! Problema o que está escrito aí! Você me trate como

\footnotetext{
${ }^{255}$ Atuei como advogada na ação de alteração de prenome dessa interlocutora. Como apenas mencionado no capítulo inicial, na audiência de julgamento contou com os testemunhos do irmão, do patrão à época e também do psicólogo da sujeita. Segundo se viu na sentença, o testemunho mais importante foi desse último. Durante aquele evento, tanto o magistrado, quanto o promotor de justiça agiram com polidez para com a interlocutora, embora por vezes se referissem a ela como "ele" ou "o requerente".
} 
senhora! Está escrito aí? Ótimo! Mas aqui estou eu na sua frente e sou uma senhora!

\section{O sigilo das informações.}

Quanto a essas coisas quando são secretas, não me incomodam tanto. Os pareceres judiciais, decisões... Acho que poderia ser mais humanizado, poderia ser diferente...Mas assim é o jeito deles[no direito]. E para mim enquanto está secreto, está ok, não tem problemas! O negócio é a exposição pública! Sabe? Exposição de você, da sua intimidade. O que tem, o que não tem, como mudou?O que mudou? Essas coisas me incomodam! A invasão da privacidade me incomoda muito! Isso é o pior!

Quando acontece algo assim comigo [revelarem o passado sem seu consentimento: o nome antigo, o corpo, etc.] vem àquela coisa na garganta! Eu explodo com a pessoa! Falo um monte de coisas: cala a sua boca! Eu te mato! Eu fico indignada mesmo! Não meta o dedo na minha vida de me expor, porque aí eu vou ficar louca! Vou ficar louca! Porque eu não faço isso com ninguém! Se eu vou apresentar você a algum cara: - "Essa é minha amiga, fulana!" Minha amiga e ponto! Seu nome e sua profissão, no máximo. Mas na maldade das pessoas: - "Essa é minha amiga que fez uma cirurgia [de alteração genital]. Foi operada!!” Parece uma coisa fantástica, coisa de novelinha das 7! Qual a utilidade disso? Coloca a pessoa num lugar ruim. Tira a possibilidade de um monte de coisas boas...Por causa de uma coisa sexual ?!?E a cada dia mais, quando eu penso nessas coisas, me pergunto qual é o incômodo? Gente, como as pessoas são incomodadas com o que as pessoas têm entre as pernas! Como isso faz a diferença na cabeça das pessoas... É uma desgraça! Uma mulher está andando na rua e alguém aponta e diz assim: - "Sabia que aquela dali tem um pinto?" - Estragam a vida da pessoa toda! Cai tudo por terra! Ela vira assim, um monstro, um marginal, uma aberração porque tem um pinto ainda. Acaba com tudo! Todas as qualidades dela vão embora. E a primeira coisa que dizem é: - "Não! Não é mulher!" Por causa de uma porra de uma genitália!! E desgraçam a vida da pessoa sem sentir remorso, sem dó, nem pena. Dizem assim: - "Ah! Desculpa, porque ninguém vê... Gente mas isso é maravilho!! Olha como ela conseguiu... Ela é 
tãoooo (ênfase no "tão") feminina.... Mas tem um pênis! Ela é tão feminina, mas tem um pinto!"

Já ouvi coisas escrotas, também! Falaram para mim: - "Nossa! Você é formada em moda! Nossa...Parabéns! Você conseguiu! Isso é uma vitória para as 'trans'!" Eu falei: - Não é uma vitória para as "trans" porque eu não estou representando porra nenhuma! Eu paguei minha faculdade! Não foram as "trans". Não foram movimentos, grupos [LGBTTT]. Não foi homem nenhum! Não foi você! Não foi o caralho nenhum! Então, não é vitória para as "trans", não! É vitória minha! E é uma coisa normal, que qualquer pessoa poderia fazer: uma faculdade. Estudou. Fez uma faculdade! Não usei em nenhum momento meu pinto para nada!(risos) $E$ eu ninguém inclusive (gargalhadas)Ele [o pênis]não tem responsabilidade nenhuma! Nem para pagar as contas da faculdade serviu! Então, assim, não tem isso de uma vitória das "trans". Os caras falam: - "Ah... Porque é a sua classe..." - Que classe, cara? "Porque você é uma ótima representante para as 'trans'..."- Que representante do quê? Eu não represento nada! Isso aqui não é um sindicato! (gargalhadas)Não existe sindicato, ser sindicalizada?!? Não recebo nada para isso! Tá doido? Vou ganhar o quê? Tem uma bolsa maquilagem? Um vale alguma coisa? Se tivesse um programa valevagina (gargalhadas) tinha dito que era "trans" há muito tempo! Como eu já fiz antes... Aí, eu seria "trans" e ponto!(risos).

\section{Publicidade da intimidade.}

Eu me sinto incomodada quando é pública, sabe? Ou quando alguém que conhece meu passado se acha no direito de contar para a outra pessoa: - "Não é mulher não, viu?" Daí, a outra pessoa que não sabe como me tratar, solta um "ele", de vez em quando. Eu não olho para quem me trata por "ele". Olho para a outra pessoa. Eu fico indignada! Acho isso ridículo! Comigo não! Quero ver uns caras falarem: - "Ah, é ele. Porque tu é homem!" Eu vou te mostrar o homem agora! Tu vai sair todo quebrado, desgraçado! 


\section{A exposição indevida da intimidade na certidão de nascimento.}

Como mencionado, atuei como advogada da interlocutora em seu processo para mudança de prenome. Na sentença está claramente dito que deverá haver sigilo das informações íntimas da sujeita, exceto quanto à averbação no livro de registros públicos local sob o argumento da defesa dos "direitos hipotéticos de eventuais terceiros".

Entretanto, embora a decisão judicial de alteração de prenome da interlocutora tenha determinado que não se mencionasse nenhuma informação na certidão de nascimento ${ }^{256}$, a tabeliã da cidade situada no estado do Maranhão/MA, onde a interlocutora tem registro de nascimento, desobedeceu às ordens do magistrado e grafou no campo "observações" do documento público de nascimento os termos:

[...] em virtude de sentença datada de xxxxx, oriunda do Juiz de Direito xxxxx, da Vara de Registros Públicos da Comarca de Brasília - DF, nos Autos de alteração de nome no xxxxx, fica o presente termo Retificado quanto ao nome do Requerente para xxxxxx. $2^{\underline{a}}$ via.

Desde então, Malévola trava outra batalha judicial para retirar tais observações indevidas que expõem sua intimidade.

De novo eu tive um incômodo muito grande com alguém invadindo a minha vida! Eu não faço isso com as pessoas...Foi por isso que o policial olhou-me de maneira estranha quando fui registrar ocorrência por causa do roubo dos meus documentos... Se bobear tem lá nos cadastros da polícia referências da mudança. E falo mais...Lá no cartório, a tabeliã fez de maldade! Certeza que a pessoa fez de maldade. Porque está escrito lá, está claro! [refere-se à ordem judicial para que não constasse na certidão que houve alteração]. Eu tenho muita vontade de sair daqui, ir ao Maranhão,

\footnotetext{
${ }^{256}$ Diz a sentença: "Determino que seja averbada a presente alteração à margem do assento de nascimento do Requerente, lavrado sob o livro $n^{\circ} \mathrm{xxxx}$, fls. Xxxx, termo $\mathrm{n}^{\circ} \mathrm{xxxx}$ do Cartório de Registro Civil de xxxxx/MA, conforme documento de fls. 16. [...] vedada qualquer menção nas certidões do registro público, sob pena de manter a situação constrangedora e discriminatória. Independentemente da expedição de mandado serve a presente sentença como instrumento hábil à averbação correspondente." No capítulo introdutório se fez a diferenciação entre "registro", "certidão", "averbação", nas acepções técnicas dos termos. Recapitulando: Registro, documento originário de declaração de fato jurídico (por exemplo, o nascimento com vida, que dá origem ao registro de nascimento), grosso modo, o Livro de Registro. Certidão, cópia transcrita dos dados que constam no livro registral, via de regra, fidedignos. À exceção se faz presente nos casos da situação das sujeitas e dos sujeitos que demandam alteração de prenome e gênero em razão do atual entendimento jurisprudencial do Superior Tribunal de Justiça (STJ) para proteger a dignidade da pessoa; Averbação, anotação feito no registro civil que declara situação de fato ou de direito;
} 
olhar para a cara dessa mulher e falar assim: - "Olha para mim! Olha pra mim!"Antes de falar qualquer coisa para ela. Dizer: - "Minha senhora, olha para mim! A senhora está vendo o que?" - "Ah estou vendo uma mulher!"(resposta imaginária da mulher) "Então, porque que você... Aí, eu pego o papel... Você sua desgraçada aqui... O juiz está dizendo, o juiz manda em você, sua vagabunda! Tira essa merda daí!" Porque sou eu quem vive essa vida! Não é você! Você não sabe nada sobre mim! Nada! Não meta o dedo na minha privacidade! Eu fico irritada! Eu fico muito irritada com isso! É invasão toda hora. Para todo mundo. Se levar o documento num lugar tem essa desgraça, tá lá. E depois você ainda encontra uma pessoa sem noção que vai virar para você:- "Ah! Você já fez a cirurgia? "Vou dizer assim: - "Por que você quer saber? Qual a importância que tem minha buceta para você? "Todas as pessoas que vierem com alguma besteira vão levar esse fora na cara! Não vou ficar calada para isso, não! Vou perguntar nesses termos mesmo: - "Qual a importância do meu genital para você?" A pessoa nunca te viu na vida e se acha no direito de fazer uma pergunta idiota dessa?!? E tudo porque no documento está uma observação maldita dessas, que me expõe e dá direito a essas maldades! Imagina se eu estiver acompanhada por alguém e um sem noção pergunta isso??A única coisa que realmente me incomoda é quando aparece algum documento com essas bobagens lá. Incomoda-me de verdade a publicização disso!

\section{Qual o sentido em ser submetida a uma categoria com a qual não se identifique como identidade? Para você tem alguma utilidade?}

Nenhuma utilidade! Não tem sentido algum! Eu não sei o que as pessoas pensavam no momento que fizeram essas pesquisas na época em que surgiu esse nome [refere-se a "transexual", "transexualismo" ou "transtorno de identidade de gênero"]. Porque tudo é tão simples: eu quero uma cirurgia no órgão genital para transformar meu corpo apenas, não minha identidade! Lógico que tudo que é médico vai ter sempre esses nomes absurdos. Nomes de doenças! Mas isso para as pessoas acabou virando sinônimo de "a aberração"! Tudo que é diferente: - "Vamos colocar um nome de anomalia e vamos torná-lo público". E para os médicos, acho que é como se fosse uma grande experiência. Tipo assim: - "Ohhhh! Vamos conseguir transformar...Realizar 'A transformação'?” Como se fosse a cirurgia capaz de 
transformar você em alguém que antes você não era antes ${ }^{257}$. Estranho é que eu escuto muito isso das pessoas: - "Ah! Quando foi que você virou... ?" Aí, eu digo: "Eu não sou a mulher maravilha que rodou e virou alguma coisa". (risos) O dia em que estou de bom humor eu uso aquela frase da música: - "Eu nasci assim, eu cresci assim, e sou mesmo assim, vou ser sempre assim..."(risos)Perguntam também assim: - "Desde quando você é mulher?" Como assim desde quando?? Aí eu devolvo: - "Desde quando você soube que você era homem? "Ainda pergunto mais: "É o seu pinto que faz de você um homem?" E para as mulheres: - "Quando você soube que você era mulher?" A questão está toda nessa porcaria de pinto ou vagina. Está toda na genitália! É sempre isso que vem primeiro e não a pessoa! Mas em alguns casos da justiça acho que há uma maldade, sabe? Porque não precisava ser assim! [refere-se à exposição dos termos contidos na certidão de nascimento]Poderiam levar para o jurídico a pessoa, o ser humano, e não "a aberração". Fica parecendo que é tudo doente mental...

\section{Um laudo para atestar que é "transexual". ( 0 controle do Estado sobre a identidade $\mathrm{e} O$ acesso à cirurgia).}

Como condição para alterar o prenome nos documentos civis, ainda durante a fase processual, tanto o juiz da Vara de Registros Públicos de Brasília/DF, quanto Ministério Público requereu que se juntasse ao processo um "laudo que ateste ser a pessoa transexual. ${ }^{258} \mathrm{~A}$ solicitação é a continuação da exigência médico-psicológica de que a sujeita é de fato uma "transexual verdadeira", objetivando, de acordo comas falas daqueles profissionais do direito, impedir o acesso de pessoas "não transexuais", "não preparadas" ou que possam vir a se arrepender das mudanças registrais. Em outras palavras, os operadores do direito pleiteiam - a pretexto de "proteger a pessoa dela mesma ${ }^{259 "}$ - resguardar eventuais

\footnotetext{
${ }^{257}$ Aqui podemos nos lembrar dos argumentos de Bruxa Malvada do Oeste quando afirma que se não era mulher antes não será a vagina capaz de transformá-la. Também nas narrativas de Úrsula - $A$ Feiticeira do Mar sobre a modificação apenas do corpo, mas nunca da identidade e mais enfaticamente em Maga Patalógica quando compara à questão da modelo internacional Lea T, dizendo "jamais uma vagina Ihe faria ser uma mulher!"

${ }^{258}$ No capítulo inicial, entrevistou-se o magistrado e um dos promotores de justiça que oficiam nesses casos.

259 Nesse ponto desejamos refletir criticamente sobre a necessidade incondicional (legal) de acompanhamento dessas ações pelo Ministério Público, tanto em defesa de eventuais "direitos
} 
direitos de terceiros ou toda a sociedade da "fraude", da "falsa transexual". Na ausência do laudo, os operadores do direito afirmam que a sujeita terá de provar, preferencialmente com testemunhas ${ }^{260}$, que é conhecida como "fulana". Entretanto, não soube de nenhum caso em que não se requeresse o laudo para o deferimento do pedido ou cujo provimento dos pedidos fosse baseado unicamente em testemunhas de que "fulana é fulana."

Ser identificada como "transexual" é de novo a merda da genitália!- "Ah! Ela tem um pinto". O que é que o Estado tem a ver se eu tenho um pinto ou uma buceta? De novo é uma importância enorme em cima da vagina. - "O que você tem aí? É um pinto ou uma vagina?" E se põe lá "transexual" significa que você tem um pinto, mas esse pinto não te faz homem! E não te faz mulher, também! Explicar que é "transexual"é para dizer que eu tenho um pinto e não sou homem!- "Ahh, Então você é o quê?!?Só pode ser transexual!" Mas se você virar e falar: - "Eu sou mulher! "Aí, eles dizem: - "Não é mulher! Você tem um pinto e demanda uma cirurgia. É obvio que você é transexual! "Não tem escapatória! É uma coisa medonha, absurda, sem sentido! Parece assim uma identidade "tampão", por falta de coisa melhor se usa essa palavra. E é continuar nas mãos de alguém para ter as minhas escolhas, a minha vida. [refere-se à tutela do Estado no acesso às alterações de prenome]É como se você fosse uma doida que precisasse de alguém para dizer quem você é. "Você tem um pinto? Então você é homem! Mas se você quer se livrar do pinto, então você é transexual!" Você nunca pode ser simplesmente você mesma: mulher. Você ser você mesma parece que você está esquizofrênica! Que está doida! Que você não sabe quem você é... Mas nós sabemos! Porém, vem um cara lá para te autorizar a fazer alguma coisa... Você tem que ser autorizada! Mas só se você passar nos testes e ganhar o laudo. Se eu passar nos testes eu posso ter o direito

\footnotetext{
difusos", que se traduzem por "direitos de terceiros" ou "defesa de toda a sociedade", quanto na tutela de "proteção" das sujeitas e dos sujeitos representada pela extinta atribuição da PRÓ VIDA (Promotoria de Justiça Criminal de Defesa dos Usuários dos Serviços de Saúde) como visto no trabalho de Flávia do Bonsucesso Teixeira (2009). Não consta expressamente nas atribuições daquela promotoria a tutela de "transexuais", mas na prática sempre ocorre. Ver em:

http://www.mpdft.mp.br/portal/index.php/conhecampdft-menu/promotorias-justica-menu/promotoriasde-justia-criminal-da-defesa-dos-usurios-de-servios-de-sade-pr-vida-mainmenu-117 Último acesso em: 16/05/15.

${ }^{260}$ É interessante notar que a identidade dessas sujeitas está sempre na dependência de outrem, seja dos "especialistas da vida alheia", seja de testemunhas, terceiros. Não há possibilidades de haver créditos à simples palavra da sujeita sobre si.
} 
de ser eu mesma! E só assim posso ser autorizada a ter a cirurgia. Fico na mão do Estado para que eles resolvam se vão me dar a cirurgia...

\section{Pessoas do passado.}

Se eu vivesse ainda no mesmo lugar... Deus me livre! Olha, se eu não houvesse me mudado de casa, com todas essas transformações, evoluções, eu poderia até estar morta! Porque ninguém respeitaria nada! Sobretudo eles continuariam a me chamar de "ele". Com o nome masculino. E parentes e vizinhos e gente que me conheceu da escola, na infância... Nunca! Nunca! (pausa) Não consigo...Não consigo nem imaginar! Eu fiz bem em vir embora. Melhor coisa que eu fiz! Sair daquele lugar porque era muito ruim. As pessoas são tão escrotas que elas não conseguem mudar o tratamento com a gente. É aquela coisa que eu sempre digo: a mudança da genitália é para gente, não adianta. As pessoas, por mais que digam que respeitam, vão ter sempre um "porém". Principalmente, essas que te conhecem do passado, da adolescência, infância... Elas vão ficar com aquela imagem: - "Ah! É um menino que virou menina!"- Então é melhor nem ficar perto dessas pessoas.

\section{Acha necessário contar sobre o passado?}

Não acho! Para quê? Que tipo de pessoa deve saber? Ninguém! Passado de quê? Sério, eu não tenho passado! Eu me lembro das coisas de criança, algumas coisas, alguns fatos, mas parece que é outra pessoa... Claro que estou envolvidalá dentro, do que era verdadeiro, do que era feminino, do que era meu. Mas o resto, do que eu tinha, da escola em relação a mim, da família em relação a mim. Que para eles era tudo "menino, menino, menino"... Não tenho! Esse tipo de passado eu não tenho! Eu tenho o passado que veio de mim. O que saí de mim para a vida! Agora o do entorno, do que me devolveram, esse não existe mais! O importante é você! Não era aquela professora maldita que ficava no teu pé. Não era aquela escola ruim que você achava um saco. Nem as suas tias que ficavam dizendo que você era um "chato", "esquisito", “doente”, "calado"! (risos)Ódio! Queria que todas já tivessem morrido... (risos).Eu as trato superbem hoje, mas com as devidas distâncias! (risos). 


\section{Autoconhecimento.}

Malévola pratica há cerca de 10 anos psicoterapia individual, segundo ela, para o autoconhecimento, para auxiliar nas escolhas de vida. Entretanto, o apoio psicoterápico não significa que ela seja submissa às opiniões do profissional. Tão pouco consinta que um laudo ou outro documento fale dela por ela. O laudo anexado ao processo de alteração de prenome foi uma negociação com o psicólogo já que fora exigido pelo Poder Judiciário. Como visto acima, a interlocutora é crítica à abordagem categorizadora característica do saber-poder médico-psicológico. Essa sujeita joga também Tarô $^{261}$ para se conhecer melhor. Atualmente, centra-se em fazer suas escolhas e construir seus próprios caminhos.

Eu sempre me lembro da oração da Gestalt ${ }^{262}$. É um texto pequenino que diz mais ou menos assim: "Eu faço as minhas coisas, você faz as suas. Eu não estou nesse mundo para viver as suas expectativas e nem você as minhas. Eu sou eu, você é você. E se por acaso nos encontrarmos é lindo; se não, nada a fazer." Guardo esse cartão até hoje e me lembro desse texto com frequência, sempre que eu conheço alguém. Aprendi que tenho que fazer minhas coisas, não posso ficar viajando em depender, inclusive das coisas de amor, de relacionamentos, de namorado, de ninguém. Eu até falo isso para alguém com quem eu venha a ter relação afetiva. Então, a partir daquele dia [a primeira sessão de psicoterapia]eu procurei meu autoconhecimento sempre. Porque eu já tenho mais de 10 anos de terapia,né? Eu também leio o Tarô para mim mesma, que é outra forma de compreender a mim, as coisas que me acontecem e as pessoas que estão ao meu redor. E desde o dia em que comecei a aceitar que somos seres sozinhos, que somos nós que temos que fazer nossas coisas, abrir nossos caminhos... Claro que a gente tem colaborações das pessoas que estão junto da gente: família, amigos e tal. As pessoas que a gente

\footnotetext{
${ }^{261}$ Existem vários tipos, formatos e tradições do Oráculo conhecido como "Tarô" ou "Tarot". De acordo com a blogueira Nanda Botelho, o Oráculo é "uma conversa com uma parte que sabe mais dentro de você mesmo." Ver em:

http://multiplasrealidades.blogspot.com.br/2009/04/o-que-e-oraculo.html Último acesso em: 16/05/15.

${ }^{262}$ Oração da Gestalt é um poema escrito pelo psicoterapeuta alemão Frederick Perls. Ele e sua esposa desenvolveram uma abordagem terapêutica chamada de "Gestalt-terapia." Ver em:

http://www.nucleogestalt.com.br/artigo.asp?id=18

Último acesso em: 16/05/15.
} 
vai conhecendo. Mas a vida é nossa! Nós que fazemos nossas escolhas e construímos nossos caminhos!

\section{Que perspectivas de futuro você prevê para as pessoas que eventualmente compartilhem (ou não) de trajetória semelhante a sua?}

A ênfase dos conselhos da interlocutora aqui é a autoproteção. "Manter uma vida meio que dupla" para que as sujeitas que não fizeram cirurgia evitem exposições desnecessárias; se protejam da maldade das pessoas ou mesmo os não corram riscos de violências. Aqui também se manifestam as dimensões da invisibilidade.

Eu acho que uma vez você com seu nome feminino, você pode ir para qualquer lugar, sabe? E mesmo antes! Acho que a vida tem oportunidades para todo mundo. Basta ter uma força interna... Mas tem que ser uma força interna muito grande, para poder aguentar. Mas acho que pode se inserir, pode ir para onde quiser. Hoje muito mais do que na época em que eu fui adolescente. Hoje é muito melhor! As coisas têm mudado muito rapidamente. Já não se pode mais dizer que há um lugar específico em que elas [mulheres de fato]podem ir. Algumas sem nenhuma alteração de corpo ou documento não se intimidam, não deixam de fazer o que acreditam! Eu só acho que elas deveriam pensar numa coisa de proteção, que poderia ser o documento de identidade, com o nome feminino, porque isso protege muito você. Te abre portas, sabe? E te deixa mais tranquila para estudar, trabalhar, planejar um futuro. E falo isso também em relação às pessoas que se afirmam travestis. Acho que elas podiam se proteger nesse sentido, também. Mas é claro que se for isso que elas desejam [a identidade feminina, mesmo que não seja "de mulher"]. Cada pessoa é de uma maneira. Não podemos nos meter nisso. Aconselha-se, mas, de repente elas gostam dessa coisa: - "Você me vê fulana, mas eu sou fulano!" Sei lá...Cada um sabe a necessidade que tem...(pausa)

Pronto! Lembrei-me agora de uma coisa que uma amiga fala. Ela diz que quando os caras querem algo mais íntimo com ela, ela fala assim: - "Ah! Eu sou mulher que mija em pé!" (risos). Eu brinco com ela dizendo: - "Fulana, você é uma travesti!"(risos)- "Olha, tem umas horas em que você faz coisas de travestis. Acho que quando você fizer a cirurgia vai se arrepender..."Ela é muito grilada com sexo e 
fala assim: - "Ah, Malévola! Você acha que se eu deixar o cara me chupar e eu o comer, ele vai pensar que sou travesti?" Eu digo: - "Meu bem, se você sente prazer, use! Use, Exercite! Até para saber se você pretende abrir mão do pênis." Porque eu imagino que seja diferente o prazer[com a vagina]. $O$ que eu tenho sentido com o pênis depois que eu tive meu nome alterado - gozar - ficou muito melhor! (risos) Gozar ficou mais tranquilo, mais fácil, sei lá. Posso até dizer que ficou mais prazeroso! Só essa coisa da intimidade... Ninguém lá fora [dos ambientes sociais]está sabendo mais de nada. Do que eu tinha, do que eu tenho.

Para outras mulheres como eu, acho que uma coisa importante no momento que ainda se tem o pênis é manter o sigilo ${ }^{263}$. Ter ainda uma vida meio que dupla para você não sofrer o preconceito e o distanciamento das pessoas. A invasão da sociedade na sua vida. Porque é uma invasão ruim! E as exposições que fazem de você são muito ruins, porque se baseiam só numa genitália, só no pênis. Só isso que importa! O resto, o que você fez, o que deixou de fazer. Se você é boa, se você é caridosa, se tem uma vida tranquila, se é religiosa... Se você paga seus impostos em dia, não interessa! Só importa que você tem um pinto! É só isso! Nada mais interessa.

\section{Futuro.}

A minha perspectiva pessoal é que eu faça essa cirurgia, sabe? Que eu tenha uma paz privativa. A minha vida privada fique em paz! De alguma forma vai se refletir lá fora. Porque o que pega comigo é essa questão da vida privada. De alguém de fora dizer: - "Você é homem! Você ainda é isso!" E a questão de, por exemplo, sofri um acidente e vou para o hospital. Vou ser exposta? As minhas questões são essas, são práticas! Eu me vejo tranquila no futuro! Mesmo que essa situação ainda dure algum tempo... Eu já consegui chegar num estado em que consigo aceitar e lidar com essas coisas, cada dia melhor, sabe? Vindo a cirurgia, lógico que vai melhorar, inclusive no aspecto sexual. Vai me dar várias possibilidades. $A$ vagina numa mulher é o que se tem como adequado, algo que se espera. O pênis é algo que a restringe... Digamos que seria uma libertação! Uma libertação do que considero feminino, totalmente! Vou conseguir viver meu feminino totalmente! Claro que é tudo muito interno. Porque a vagina e o pênis não são públicos. A partir da hora que se

\footnotetext{
${ }^{263}$ Aqui igualmente se encontra presente uma das dimensões da invisibilidade.
} 
tornam públicos é que vira a merda toda! Porque a partir da hora que a pessoa sabe que eu tenho um pênis, muda tudo! Muda tudo nela, né? Eu continuo sendo a mesma, mas na cabeça dela muda tudo! Então, quando eu tiver a vagina vai ficar tudo tranquilo, eu acho. É tudo interno! Vai mudar só para mim. As outras pessoas não vão saber de nada. E lógico que eu vou estar mais aberta, mais tranquila, na hora de acessar outras possibilidades. Eu vou poder chegar e me mostrar, até mesmo no sistema de saúde, vou fazer uma consulta sem preocupações de mais nada.

\section{A espera pela cirurgia.}

Não tenho mais essas angustias todas, não. Claro que eu penso como poderia ser bom nesse momento. Mas ao mesmo tempo, me leva a testar as relações. Aprofundar, porque, por exemplo, com esse menino, eu tenho de fazer uma base de amizade muito sólida porque se eu precisar vir a contar isso, acho que se ele for adulto e maduro, vai ver que existe uma base sólida. Que eu não sou um problema para ele. Que eu venha a ser um problema na vida dele... Hoje estou tranquila! Estou fazendo todas as coisas que tenho que fazer. Não paro mais a minha vida para esperar a cirurgia. Porque é importante você ter uma vida. A cirurgia não vai solucionar todos os seus problemas! Antes, eu pensava um monte de besteiras... Não queria viver, era dolorido esperar, não havia a quem procurar. Era muito difícil até passar os dias... Era ruim não ter ao menos uma consulta marcada, sabe? A minha preocupação agora era essa: colocar meu pezinho lá dentro [do HCPA]! Ter a garantia que estou lá, que sou vista e que existo dentro do sistema [SUS]. Eles têm um protocolo com prazos para cumprir. Então, acho que é uma angústia normal. 


\section{CONCLUSÃO}

Ao longo do trabalho, tentamos apresentar as dissonâncias entre a identidade real das sujeitas e a obrigatoriedade ou a submissão ao que se nomeia por "transexualidade" para se obter êxito nos pleitos cirúrgicos ou jurídicos. As cenas de vidas baseadas nas narrativas das quatro interlocutoras desse trabalho ilustram bem os dilemas entre ser e expressar-se mulher e se ver coagida a carregar uma identidade "transexual": as negociações, os limites, as impossibilidades ou indiferença.

A visão médico-psicológica e jurídica sobre as identidades e necessidades das sujeitas dessa dissertação é excessivamente estreita e impermeável às perspectivas que efetivamente dão sentido à vida delas. Parte de requisitos médicos-psicológicos extremamente restritivos formulados apenas para a chancela(ou controle) da cirurgia, não abrindo espaço para a singularidade da existência das sujeitas. O Poder Judiciário se utiliza desses mesmos critérios para o deferimento dos pedidos de alteração de prenome e gênero, mantendo-se "surdo" a tudo mais que as sujeitas dizem de si.

Em todas as trajetórias de vida aqui apresentadas existe a necessidade e o desejo pelo reconhecimento pleno. O acolhimento da identidade de mulher que supera em muito as demandas cirúrgicas e jurídicas. Fundamental à compreensão das sujeitas como são e se expressam para a satisfação das relações íntimas, familiares e sociais.

Alguns aspectos comuns nas trajetórias das quatro sujeitas merecem ser relembrados.

O lugar da magia nos relatos de vida das interlocutoras é importante para a compreensão das mudanças de suas identidades que elas desejam que se efetivem. Em alguns trechos, a mudança se associa diretamente à cirurgia. Entretanto, essa mudança mostra-se muito mais abrangente e profunda que as adequações físicas e jurídicas: tem relação com o (auto) reconhecimento. Assim, em Bruxa Malvada do Oeste, a magia do "esquecimento" coletivo era esperada no retorno à Rondônia após a cirurgia realizada com sucesso na Tailândia; para Úrsula - A Feiticeira do Mar, a mágica terá mais eficácia com a cirurgia, na busca pela paz 
interior,do que com a alteração no mundo externo; com Maga Patalógica, a magia se situa, além das práticas religiosas, nas conquistas diárias dos espaços sociais, na tranquilidade que a cirurgia lhe proporciona; finalmente em Malévola, a cirurgia poderá trazer algum nível de conforto íntimo, como desejado desde a infância quando imaginava que o pênis iria desaparecer e se transformar numa vagina. Em todas elas, há a dissintonia acentuada na forma como se veem e como são vistas. $O$ discurso mágico parece ser um mecanismo de encorajamento às ideias de poder para mudar as situações. Porém, igualmente em todas, está aclara percepção sobre os limites das transformações tanto físicas e jurídicas, quanto sociais.

As experiências de humilhação e insulto são enfrentadas pelas interlocutoras de formas diferentes. As sujeitas passaram (e ainda passam) por situações de violência moral que se assemelham a rituais públicos de humilhação. De forma marcante, Úrsula - A Feiticeira do Mar vivenciou um desses rituais quando da cena no shopping center: retirada violentamente do banheiro feminino na frente de todos sem direito a fazer as necessidades fisiológicas em quaisquer recintos do estabelecimento comercial. Como tentativa de solução, defendeu-se com um processo judicial ainda em curso. Bruxa Malvada do Oeste se viu publicamente exposta ainda na adolescência ao noticiarem em jornais os conflitos com a direção do colégio secundarista na obrigatoriedade do uso de uniformes distintos entre moças e rapazes. Ela decidiu por não estender seu sofrimento com outra discussão pública. Já Malévola frequentemente passa por humilhações todas as vezes que instada a apresentar a certidão de nascimento, pois de forma inconteste está grafado naquele documento que houve modificação em seu prenome. Igualmente essa interlocutora escolheu a satisfação da dignidade via ação judicial que por hora ainda está sem desfecho. Nas evidências do reconhecimento de sua identidade pelos espíritos e pessoas, Maga Patalógica tem aprendido a lidar com as situações de humilhações provocadas por participantes nas festas do Candomblé. Essa última interlocutora goza do respeito e consideração dos frequentadores, conquistados ao longo dos anos e por isso parece vivenciar os eventos de humilhação com menos sofrimento.

A invisibilidade das sujeitas(ou sua visibilidade de forma não pretendida, tais como nas categorias "transexual" ou masculina) tem uma multiplicidade de sentidos que vão se modificando ao longo da vida. Na infância, de um modo geral, 
não são identificadas prontamente como de fato são: meninas. Os traços femininos que compõem suas identidades são invisibilizados ou sistematicamente desconsiderados. $\mathrm{Na}$ adolescência e maturidade, a invisibilidade torna-se ambígua: de um lado as características físicas masculinas que elas desejam esconder se acentuam; de outro, a percepção de si como mulheres aumenta, surgindo também a necessidade de interferir na aparência. Mas agora as sujeitas enfrentam dificuldades ainda maiores quando não visíveis conforme suas identidades. E quando a ambiguidade deixa de existir com as modificações corporais (uso de hormônios, roupas, maquilagens, entre outros) ela aparece no plano da intimidade. Nesse ponto, vale rememorar os relatos de Malévola e as limitações afetivas e sexuais com o atual namorado. Muito embora, a mesma interlocutora, em comparação com as demais, tenha podido se realizar sexualmente no passado para além dos dilemas de gênero. A invisibilidade parece ter fim com a cirurgia, como nos faz lembrar os relatos de Maga Patalógica na vida quotidiana.

Quanto às características de distinção entre as interlocutoras desse trabalho e as pessoas que se identificam como transexuais há a identidade expressada como mulheres e a negativa evidenciada em ser vistas ou comparadas às primeiras. Todas as entrevistadas se distanciam das pessoas que se afirmam transexuais. Entretanto, Bruxa Malvada do Oeste é a que mais radicalmente diferencia ao discorrer sobre as dissintonias entre ela e "o delegado de polícia de Goiânia". Talvez para a agente policial referida pela interlocutora (e quiçá muitas outras), a identidade transexual exista, faça sentido e seja reveladora de si e suas questões íntimas e sociais. Entretanto, de acordo com as sujeitas desse trabalho, o que se nomeia como "transexualidade" não é uma identidade, mas circunstâncias temporárias, condição ou situação liminar (cada uma terá uma explicação singular que se aproximará dessas definições), com diferenças incontornáveis que tornam a suposta identidade transexual questionável no plano identitário. E se de fato for uma identidade, não se aplica às sujeitas, como se viu nas trajetórias de vida.

Ponto que merece destaque é a relação de diferenciação entre as idades das sujeitas que demandam as cirurgias nos âmbitos públicos e privados. Como se viu ao longo do trabalho, todas as interlocutoras aqui se situam na faixa etária entre 39-43 anos de idade. Dessas, as que realizaram as cirurgias o fizeram com mais de 28 anos (Bruxa Malvada do Oeste). Maga Patalógica, em razão da longa espera de 
15 anos nos serviços públicos de saúde, foi adequada quando estava em torno dos 35 anos. As duas que aguardam os procedimentos ou estão em "filas" há pelo menos seis anos (Úrsula) ou não obtiveram meios financeiros ou legais para realizar antes (Malévola afirma estar pronta desde a juventude, porém apenas agora via judicial conseguiu as primeiras consultas). Bruxa Malvada do Oeste, a única das sujeitas aqui entrevistadas que se operou fora do país e arcando com todos os custos, em comparação com Maga Patalógica realizou a cirurgia muito anos antes. Pode-se fazer a seguinte correlação: as sujeitas que possuem condições de arcar com os custos das cirurgias, conseguem a adequação genital bem antes que aquelas que aguardam nos serviços públicos de saúde. No capítulo inicial, chamamos a atenção para a realidade do País. No Brasil da atualidade os cofres públicos só custeiam legalmente as intervenções feitas nos quatro hospitais credenciados. Em razão de má-gestão administrativo-financeira ou falta de interesse político-social, desses quatro hospitais, apenas o da cidade de Porto Alegre/RS ainda recebe sujeitas tanto do estado do Rio Grande do Sul, como de todos os outros entes federados, sejam estados ou municípios. Assim, a demanda pelas cirurgias aumenta drasticamente enquanto os recursos os disponíveis nos serviços públicos diminuem. Aquelas sujeitas que dispõem condições econômicas e têm um mínimo de acesso às informações podem ter êxito rapidamente nas incontáveis clínicas particulares espalhadas pelo Brasil. No mundo, existem ainda centenas de possibilidades, cuja Tailândia na Ásia figura como um dos principais destinos, mesmo para aquelas que não falam outro idioma (basta lembrar-se de Bruxa Malvada do Oeste e sua efetiva comunicação com a equipe médica). Em resumo, fatores sociais e, sobretudo, econômicos, distanciam as idades entre as sujeitas que realizam as cirurgias mais ou menos prematuramente.

Finalmente, nessas páginas apresentamos cenas das vidas de mulheres: sem sublinhado, vírgula ou negrito; sem bulas; que perderam tempo; e com um pênis. Nas narrativas aprendemos que são "apenas" mulheres com suas singularidades, batalhas, derrotas e vitórias. Mulheres como cada uma de nós, das "revolucionárias" as "mulherzinhas normais". E nem os corpos as limitaram. Veem-se a si mesmas como mulheres a despeito de haverem nascido com um pênis entre as pernas. Em alguns casos, a cirurgia é mais um conforto pessoal do que um componente da identidade. 
Retomando os ensinamentos do mestre de Carlos Castañeda -Don Juanque alertava ao pupilo que as pessoas enganadoras "cantam as canções de outras sem nem saber o que quer dizer", pode-se pensar nos "especialistas da vida alheia" aqui debatidos como "cantores das canções de outrem". E como se viu, apenas essas sujeitas sabem das suas canções: o quanto de dor, sofrimento e aprendizagem tiveram de passar para encontrar a melodia sublime da alma (que não é uma linha de chegada, mas reencontrada a cada dia!). Somente elas sabem o que suas músicas significam. Ninguém mais.

Os caminhos percorridos por elas não foram justos, mas também não foram em vão. Elas são o resultado de quem sempre foram. $O$ tempo fluiu, as aparências modificaram-se inúmeras vezes, mas a essência é a mesma da infância: são mulheres. Pensando assim, um "ponto" significa um lugar onde a sujeita se sente naturalmente feliz e forte. Ensina-nos Don Juan (com modificações):

Uma mulher de conhecimento é aquela que seguiu honestamente as dificuldades da aprendizagem. Uma mulher que, sem se precipitar nem hesitar, foi tão longe quanto pôde para desvendar os segredos do poder e da sabedoria.

Com seus devidos "pontos" encaminhados, agora ao mistério de viver!

\author{
"Same person. No differences at all. Just a different sex." \\ ("A mesma pessoa. Nenhuma diferença. Apenas um sexo diferente.") \\ (Orlando: a mulher imortal - Sally Potter).
}




\section{REFERÊNCIAS BIBLIOGRÁFICAS.}

ALMEIDA, Michele Faise de. Direitos, demandas e narrativas das mulheres: Notas etnográficas dos discursos na arena jurídica e na militância online/offline. Dissertação de mestrado apresentada à Faculdade de Direito da Universidade de Brasília - UnB, 2014.

BUTLER, Judith P. Problemas de gênero: feminismo e subversão da identidade. $2^{\mathrm{a}}$ Ed. Rio de Janeiro: Civilização Brasileira, 2008.

BENTO, Berenice Alves de Melo. A reinvenção do corpo: sexualidade e gênero na experiência transexual. Tese de doutorado apresentada ao Departamento de Sociologia da Universidade de Brasília - UnB. 2003.

BORBA, Rodrigo. Sobre os obstáculos discursivos para a atenção integral e humanizada à saúde das pessoas transexuais. Em Revista Latinoamericana, $\mathrm{n}$. 17, agosto de 2014, pp. 66-97.

BORGES, Antonádia. Ser embruxado: notas epistemológicas sobre razão e poder na antropologia. Civitas. Porto Alegre: 2012, v. 12, no 3, p. 469-488.

BOURDIEU, Pierre. A ilusão biográfica. In: AMADO, Janaína e FERREIRA, Marieta de Moraes (org.). Usos e abusos da história oral. 8. ed. Rio de Janeiro: Editora FGV, 2006.

BRASIL. Plano Integrado de Enfrentamento da Feminização da Epidemia de Aids e Outras DST. Brasília, Ministério da Saúde, 2007.

.Constituição da República Federativa do Brasil de 1988. In: Vade mecum acadêmico de direito. Organização por Anne Joyce Angher. São Paulo: Rideel, 2ª ed., 2012a.

Brasília: Ministério da Saúde, 2007.

Carta dos Direitos dos Usuários da Saúde. $2^{\mathrm{a}} \mathrm{ed}$. . Lei no 11.340 de 7 de agosto de 2006.(Lei Maria da

Penha).

Lei $\mathrm{n}^{\circ} \mathbf{6 . 0 1 5}$, de 31 de dezembro de 1973. Dispõe sobre os Registros Públicos e dá outras providências. In: Vade mecum acadêmico de direito. Organização por Anne Joyce Angher. São Paulo: Rideel, $2^{\underline{a}}$ ed., $2012 b$.

Lei no 10.406, de 10 de janeiro de 2002. Institui o Código Civil. In: Vade mecum acadêmico de direito. Organização por Anne Joyce Angher. São Paulo: Rideel, 2ª ed., 2012c.

Juizados Especiais Cíveis e Criminais).

Lei no 9.099 de 26 de setembro de 1995 (Lei dos Lei no 8.069 de 13 de julho de 1990 (Estatuto da

Criança e do Adolescente). 
CAETANO, Dorgival; DOMINGUES, Maria Lúcia; MARCOLIN, Marco Antônio. Classificação de Transtornos Mentais e de Comportamento da CID - 10: Descrições Clínicas e Diretrizes Diagnósticas. 1993. Porto Alegre: Artes Médicas.

CALDEIRA, Teresa Pires do Rio. A presença do autor e a pós-modernidade em antropologia. Em Revista Novos Estudos CEBRAP. № 21 julho de 1988. Pp. 133157.

CARDOSO DE OLIVEIRA, Luís Roberto. Direito legal e insulto moral: dilemas da cidadania no Brasil, Quebec e EUA. (Coleção Diretos, conflitos e segurança pública) 2ª Ed. Rio de Janeiro: Garamond, 2011.

CARDOSO DE OLIVEIRA, Luís Roberto. Prefácio em Dimensões da violência: conhecimento, subjetividade e sofrimento psíquico. Mériti de Souza; Francisco Martins e José Newton Garcia de Araújo (orgs.). São Paulo: Casa do psicólogo, 2011.

A dimensão simbólica dos direitos e a análise dos conflitos. Revista de Antropologia, São Paulo, v. 53, n. 2, 2010.

O material, o simbólico e o contraintuitivo: uma trajetória reflexiva. Série Antropologia Vol. 421, Brasília: DAN/UnB, 2008, p. $24-25$.

.Existe Violência Sem Agressão Moral?. Em Revista Brasileira de Ciências Sociais. V.23, n. 67 junho 2008. Pp. 135146.

.O ofício do antropólogo, ou como desvendar evidências simbólicas. Série Antropologia. Volume 413, Departamento de Antropologia da Universidade de Brasília: DAN/UnB, 2007.

Honra, Dignidade e Reciprocidade em "A nova ordem social: perspectivas da solidariedade contemporânea". Série Antropológica. Vol 344. Rio de Janeiro: Vozes, 2004.

CONSELHO FEDERAL DE MEDICINA - CFM. Resolução ํo 1.955/10. Publicada no D.O.U de 03/09/2010, seção 1, p. 109-110. Revoga a Resolução CFM № 1.652, de 06/11/202.

Disponível em: http://www.portalmedico.org.br/resolucoes/CFM/2002/1652 2002.htm Último acesso em 27/02/2015.

CASTAÑEDA, Carlos. A erva do diabo: as experiências indígenas com plantas alucinógenas reveladas por Dom Juan (The teachings of Don Juan). Rio de Janeiro: Editora Record: 3를. Ed. Trad. Luzia Machado da Costa. 2006.

CASTRO, Marcus Faro de. Formas jurídicas e mudança social: interações entre o direto, a filosofia, a política e a economia. São Paulo: Saraiva, 2012 (Coleção direito, desenvolvimento e justiça: série produção científica. 
DEBERT, Guita Grin; Oliveira, Marcela Beraldo de. Os modelos conciliatórios de solução de conflitos e a "violência doméstica". Revista Cadernos Pagu (29): São Paulo, julho-dezembro de 2007. pp. 305-337.

DINIZ, Maria Helena. O estado atual do biodireito. São Paulo: Saraiva, 2001.

DUMONT, Louis. A comunidade antropológica e a ideologia em "O individualismo: uma perspectiva antropológica da ideologia moderna". Rio de Janeiro: Rocco, 2000. pp. 201-236.

GOFFMAN, Erving. Estigma: notas sobre a manipulação da identidade deteriorada. Tradução: Mathias Lambert. 2004. Arquivo digital disponível em: http://disciplinas.stoa.usp.br/pluginfile.php/308878/mod resource/content/1/Goffman $\% 20 \% 20$ Estigma.pdf

Último acesso em: 27/02/15.

HARDING, Sandra. Ciencia y feminismo. Madrid, Espanha: Ediciones Morata, 1996.

HONNETH, Axel. Invisibility: on the epistemology of 'recognition'. In Recognition.2001.

Disponívelem:

http://www.readcube.com/articles/10.1111\%2F1467-

8349.00081 ? $r 3$ referer=wol\&tracking action=preview click\&show checkout=1\&purc hase referrer=philpapers.org\&purchase site license=LICENSE DENIED NO CUS TOMER

último acesso em: 27/02/15.

JOHN JONES, Evan; VALIENTE, Doreen. Feitiçaria: a tradição renovada (Witchcraft: a tradition renewed). Rio de Janeiro: Editora Bertrand Brasil, 1992.

KULICK, Don. Travesti: prostituição, sexo, gênero e cultura no Brasil. Tradução, Cesar Gordon. Rio de Janeiro: Editora Fiocruz, 2008.

LAQUEUR, Thomas Walter. Inventando o sexo: corpo e gênero dos gregos a Freud. Rio de Janeiro. Editora RelumeDumará, 2001.

LAW, John. After method: mess in social science research. London. Editora Routledge Taylor \& Francis Group, 2004.

MAUSS, Marcel. Ensaio sobre a Dádiva: forma e razão de troca nas sociedades arcaicas. em Sociologia e antropologia. Tradução Paulo Neves. São Paulo: Cosac Naify, 2003.

MENDES, Regina Lúcia Teixeira. Do princípio do livre convencimento motivado: legislação, doutrina e interpretação de juízes brasileiros. Rio de Janeiro: Lumen Juris, 2011.

MINISTÉRIO DA SAÚDE, Portaria 1.707, publicada no Diário Oficial da União D.O.U, em 19 de agosto de 2008. 
D.O.U, em 20 de agosto de 2008.

Portaria 457, publicada no Diário Oficial da União -

MIRANDA, Alessandra de La Vega. Em briga de marido e mulher o Judiciário mete a colher: qual a "medida"? Uma etnografia sobre as práticas judiciárias "conciliatórias" de conflitos em Juizados de Violência Doméstica do Distrito Federal. Tese de doutorado apresentada a Faculdade de Direito da Universidade de Brasília - UnB. 2014.

http://hdl.handle.net/10482/17335

Último acesso em 12/05/15.

PEIRANO, Mariza. O dito e o feito: ensaios de antropologia dos rituais. Org Mariza Peirano. Rio de Janeiro: Relume Dumará: Núcleo de Antropologia da Política/UFRJ, 2002.

PERRIN, Emmanuel. Transsexualisme: iln'estofficiellement plus considérécommeunemaladiementale en France.MaxiSciences. França, 15 fev 2010. Disponível em:

http://www.maxisciences.com/transsexualisme/transsexualisme-il-n-estofficiellement-plus-considere-comme-une-maladie-mentale-en-france art5849.html Último acesso em: 16/05/15.

POTTER, Sally. Orlando: a mulher imortal. Filme inspirado na Obra "Orlando" de Virgínia Wolf. 94 minutos. DVD Vídeo: Inglaterra, 1992.

SALES, Dimitri Nascimento. Diversidade sexual, proteção constitucional e controle de convencionalidade. Tese de Doutorado apresentada ao Departamento de Direito da Pontifícia Universidade Católica de São Paulo (PUC/SP), 2014.

SANGTIN WRITERS. Playing with fire: feminist thought and activism through seven lives in India.Anupamlata... et al: Richa Nagar: foreword by Chandra TalpadeMohanty. Ed. University of Minnesota. Minnesota: 2006.

SEGATO, Rita Laura. Inventando a Natureza: família, sexo e gênero no Xangô do Recife.em Anuário Antropológico Ed. Tempo Brasileiro: Laranjeiras/RJ, 1985.

SERANO, Julia. Whipping girl: a transsexual woman on sexism and the scape goating of femininity. Disponível em:

https://books.google.com.br/books?id=fR5jij5h5g1MC\&printsec=frontcover\&dq=Whip ping + Girl\&hl=pt-

BR\&sa $=X \& e i=E y \quad$ VKqoDcewsASP94D4Dw\&ved=0CB0Q6AEwAA\#v=onepage\&q= Whipping\%20Girl\&f=false

Último acesso em: 12/05/15.

SILVA JUNIOR, Assis Moreira. Diversidade sexual e inclusão social: uma tarefa a ser cumprida. Franca/SP: Editora Lemos e Cruz, 2014.

STARHAWK. A dança cósmica das feiticeiras: guia de rituais à Grande Deusa. Tradução de Ann Mary Fighiera Perpétuo. Rio de Janeiro: Record, 1993. 
TAYLOR, Charles. El multiculturalismo y "la política del reconocimieto". Traducción de Mónica Utrilla de Neira. México, D.F: Fondo de cultura económica, 1993.

TEIXEIRA. Flavia do Bonsucesso. Vidas que desafiam corpos e sonhos: uma etnografia do construir-se outro no gênero e na sexualidade. Tese de doutorado apresentada ao Instituto de Filosofia e Ciências Humanas da Universidade Estadual de Campinas/SP, 2009.

TURNER, Victor W. O processo ritual: estrutura e antiestrutura. Tradução de Nancy Campi de Castro e Ricardo A. Rosenbusch. 2ª Edição. Petrópolis, RJ: Vozes, 2103. - (Coleção Antropologia).

VIEIRA, Tereza Rodrigues. A bioética e o direito à adequação de sexo do transexual. In: (coord.). Bioética e sexualidade. São Paulo: Editora Jurídica Brasileira, 2004.

WOOLF. Virginia. Orlando = Orlando: a biography. Edição bilíngue portuguêsinglês. Tradução e notas Doris Goettems. São Paulo: Editora Landmark, 2013. 